\author{
Universidade de São Paulo \\ Faculdade de Filosofia, Letras e Ciências Humanas \\ Departamento de Letras Modernas \\ Programa de Estudos da Tradução
}

RODRIGO GODINHO TREVISAN

Tradução comentada da obra Le Petit Prince, de Antoine de SaintExupéry, do francês ao nheengatu

(versão corrigida) 


\section{RODRIGO GODINHO TREVISAN}

\section{Tradução comentada da obra Le Petit Prince, de Antoine de Saint- Exupéry, do francês ao nheengatu (versão corrigida)}

Dissertação apresentada ao Programa de Pós-Graduação em Estudos da Tradução da Faculdade de Filosofia, Letras e Ciências Humanas da Universidade de São Paulo para obtenção do título de Mestre em Estudos da Tradução.

Área de concentração:

Estudos da Tradução

Orientador:

Prof. Dr. Eduardo de Almeida Navarro

De acordo,

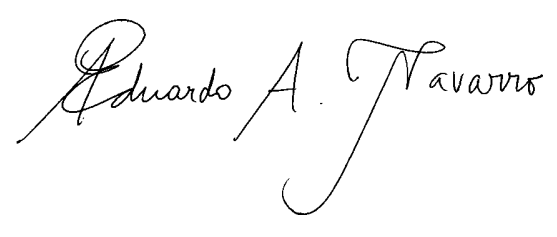

Prof. Dr. Eduardo de Almeida Navarro

São Paulo 
Autorizo a reprodução e divulgação total ou parcial deste trabalho, por qualquer meio convencional ou eletrônico, para fins de estudo e pesquisa, desde que citada a fonte.

Catalogação na Publicação

Serviço de Biblioteca e Documentação

Faculdade de Filosofia, Letras e Ciências Humanas da Universidade de São Paulo

$\mathrm{T} 814 \mathrm{t}$

Trevisan, Rodrigo Godinho

Tradução comentada da obra Le Petit Prince, de Antoine de Saint-Exupéry, do francês ao nheengatu / Rodrigo Godinho Trevisan ; orientador Eduardo de Almeida Navarro. - São Paulo, 2017.

$228 \mathrm{f}$.

Dissertação (Mestrado) - Faculdade de Filosofia, Letras e Ciências Humanas da Universidade de São Paulo. Departamento de Letras Modernas. Área de concentração: Estudos da Tradução.

1. nheengatu. 2. tradução. 3. Le Petit Prince. 4. revitalização linguística. 5. Amazônia. I. Navarro, Eduardo de Almeida, orient. II. Título. 


\section{Tradução comentada da obra Le Petit Prince, de Antoine de Saint- Exupéry, do francês ao nheengatu}

Dissertação apresentada ao Programa de Pós-Graduação em Estudos da Tradução da Faculdade de Filosofia, Letras e Ciências Humanas da Universidade de São Paulo para obtenção do título de Mestre em Estudos da Tradução.

Área de concentração:

Estudos da Tradução

Orientador:

Prof. Dr. Eduardo de Almeida Navarro

Aprovado em:

Banca Examinadora:

Prof. Dr. Eduardo de Almeida Navarro Julgamento
Universidade de São Paulo

Assinatura

Julgamento

Assinatura 


\section{AGRADECIMENTOS}

Meus primeiros agradecimentos vão para os meus três professores de nheengatu: Eduardo de Almeida Navarro, Marcel Twardowsky Ávila e Celina Menezes da Cruz.

Ao professor Navarro pela amizade, orientação e confiança. Por mostrar aos seus alunos que um professor é muito mais que uma importante figura em sala de aula, por ensinar com entusiasmo e por dividir de forma muito generosa a sua sabedoria.

Ao meu grande amigo Marcel Ávila por ter me ajudado muito nesta jornada, por compartilhar o seu conhecimento sem nenhum tipo de vaidade, pelas risadas e conversas intermináveis.

À professora Celina pelo carinho com que sempre recebeu os estudantes de São Paulo em São Gabriel da Cachoeira, por sua alegria e por nos fazer sentir em casa na Amazônia.

Também agradeço à professora Adriana Zavaglia, da FFLCH-USP, pelas diversas leituras que fez do meu trabalho, desde a graduação até o término do mestrado.

Agradeço também a todos os professores da FFLCH-USP e aos meus colegas de graduação e pós-graduação por terem sido importantes em minha formação.

Ao professor Auxiliomar Ugarte, da UFAM, pela leitura atenta e pelos comentários a respeito desta dissertação.

Ao Dom Edson Damian, bispo do Alto Rio Negro, pela bondade com que sempre nos recebeu e nos ajudou em São Gabriel da Cachoeira.

Aos meus pais, Olair e Ana Lúcia, por terem me educado e transmitido os valores que me guiam, pelo amor e pela dedicação aos filhos. À minha irmã, Verônica, e às minhas tias, Beatriz e Regina, por estarem sempre ao meu lado.

Ao Jorge, à Tais e ao Gustavo por terem me recebido tão bem em sua linda família.

E, por último, à Camilla de Rezende, a pessoa mais importante em todo este processo, pelo amor, carinho e companheirismo que compartilhamos todos os dias, por me alegrar e ser tão especial de um modo extremamente natural. 


\section{RESUMO}

A língua geral amazônica (LGA), língua de base tupi, chamada em meados do século XIX de nheengatu (nhe'enga "língua" + katu "bom", "boa"), foi mais falada que o português em toda a Amazônia até o término do século XIX. Após uma série de fatores que levaram ao seu enfraquecimento, hoje se concentra na região do Alto Rio Negro, onde é língua oficial do município de São Gabriel da Cachoeira - AM. Por ser uma língua historicamente veiculada pela oralidade e pela ainda tímida elaboração de materiais para seu estudo e divulgação, iniciativas relacionadas à tradução ao nheengatu mostram-se como estratégias interessantes a favor da revitalização dessa língua e da contribuição para a consolidação de um registro escrito na mesma. Insere-se nesse contexto a tradução do livro Le Petit Prince, de Antoine de Saint-Exupéry, do francês ao nheengatu. O registro escrito adotado em minha proposta de tradução foi estabelecido com base nos textos em e sobre o nheengatu produzidos entre a segunda metade do século XIX e a primeira do século XX e no confronto desse período com a língua em seu estado atual. Além de aumentar o número de materiais escritos na língua, utilizados principalmente no ambiente escolar amazônico, a tradução proposta nesta dissertação vem acompanhada de uma seção em que apresento comentários a respeito das escolhas tradutológicas adotadas por mim, que se relacionam a aspectos linguísticos e culturais envolvidos no processo tradutório. Com o propósito de contribuir não apenas para o fortalecimento do nheengatu, as discussões sobre questões teóricas e modalidades de tradução também podem se somar às contribuições no campo dos Estudos da Tradução.

PALAVRAS-CHAVE: nheengatu; tradução; Le Petit Prince; revitalização linguística; Amazônia. 


\begin{abstract}
The Amazon general language (AGL), a language based on Tupi, known as Nheengatu in the mid XIX century (nhe'enga "language" + katu "good"), was more broadly used than Portuguese in the Amazon area until the end of the XIX century. After a series of factors that led to its weakening, the language now is concentrated in the Alto Rio Negro area, where it is established as the official language of the São Gabriel da Cachoeira town, in the state of Amazonas. Since it is a language that has been historically used orally and the development of materials to study and disclose it is still stagnant, measures related to the translation into Nheengatu have proved to be interesting strategies favoring the revitalization of the language and the contribution for a consolidation of a written register in it. In this context we find the translation of Antoine de Saint-Exupéry's book, Le Petit Prince, from French to Nheengatu. The written register adopted in my translation proposal was established based on texts in Nheengatu, and about the language, produced between the second half of the XIX century and the first half of the XX century and the confrontation in this period with the language in its current state. Besides increasing the quantity of material written in the language, used mainly in the Amazon school environment, the translation put forth in this dissertation comes with a section in which I present comments concerning of the translation choices I adopted, which relate to linguistic and cultural aspects involved in the translation process. Aiming at contributing not only to strengthen the Nheengatu language, the discussions on theoretical matters and translation modalities may also add to the contributions to the Translation Studies field.
\end{abstract}

KEYWORDS: Nheengatu; translation; Le Petit Prince; language revitalization; Amazonia. 


\section{LISTA DE QUADROS}

Quadro 1: Diferenças entre crianças e adultos em Le Petit Prince …….......................................................19

Quadro 2: Le Petit Prince em cordel ..................................................................................................

\section{LISTA DE TABELAS}

Tabela 1: Empréstimos do português adotados em Muruxawamirĩ.

Tabela 2: Decalques em nheengatu, oriundos do português, adotados em Muruxawamirĩ...... .183

Tabela 3: Aiguilleur nas traduções de Le Petit Prince ao português ..... 201 


\section{Sumário}

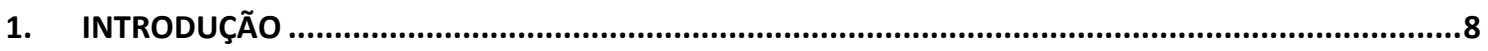

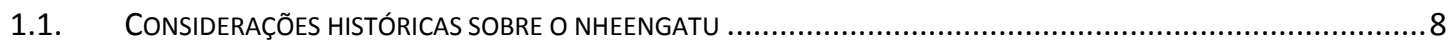

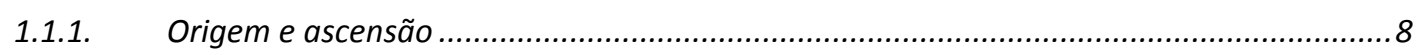

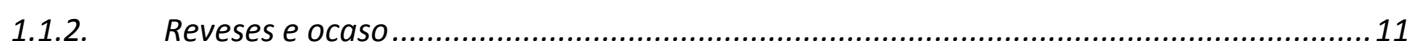

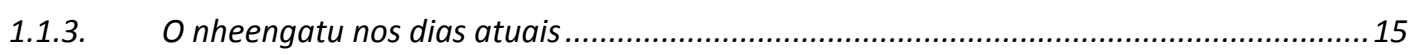

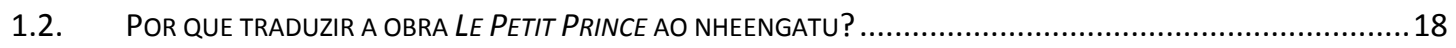

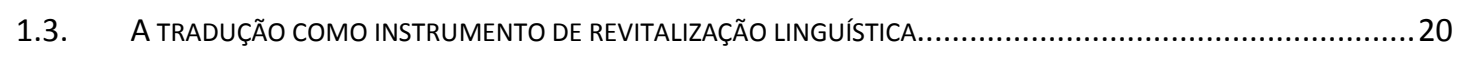

1.3.1. A tradução como enriquecimento da língua-alvo ........................................................2

1.3.2. (In)fidelidades e adaptações à língua e à cultura de destino ...........................................27

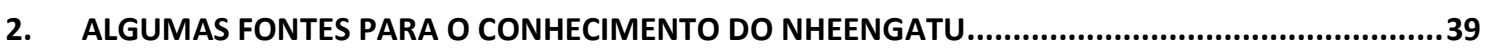

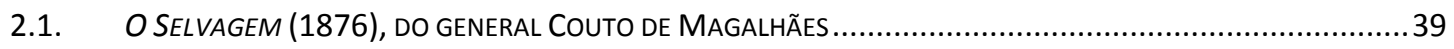

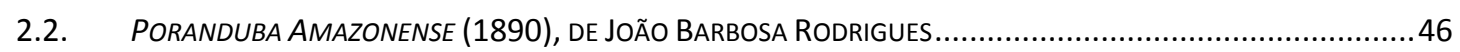

2.3. ELEMENTOS NECESSÁRIOS PARA APRENDER O NHEENGATÚ (1909), DE DOM FREDERICO COSTA .....................48

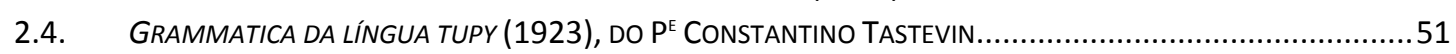

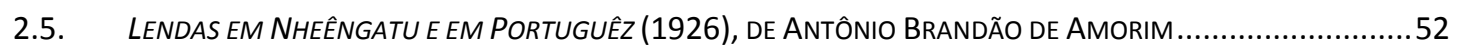

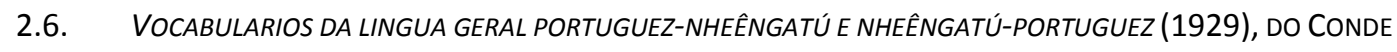

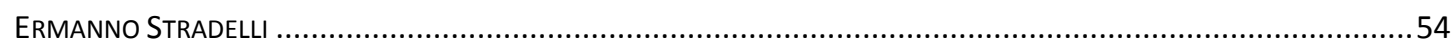

3. FERRAMENTAS TRADUTÓRIAS E PARA A ANÁLISE DA TRADUÇÃo .............................................56

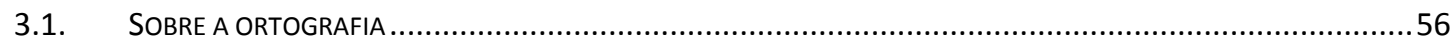

3.1.1. Ortografia adotada na tradução de Le Petit Prince ao nheengatu ....................................56

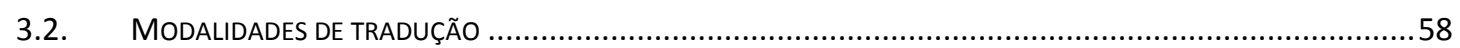

4. MURUXAWAMIRĨ (TRADUÇÃO INTEGRAL DA OBRA LE PETIT PRINCE AO NHEENGATU) ...............60

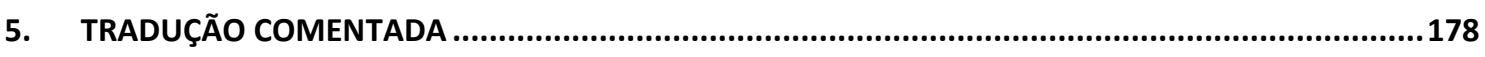

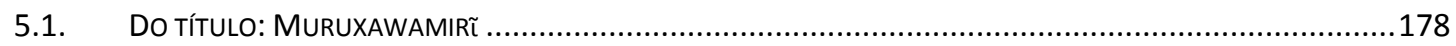

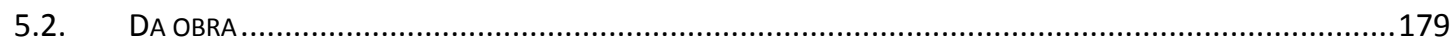

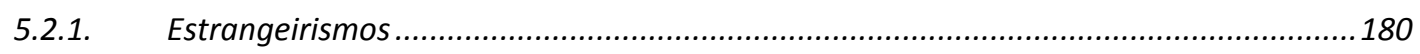

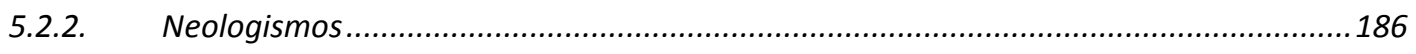

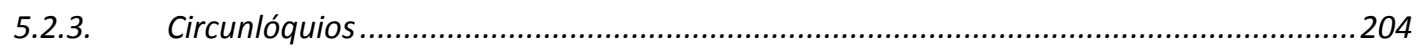

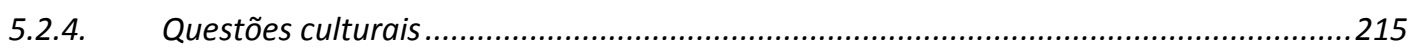

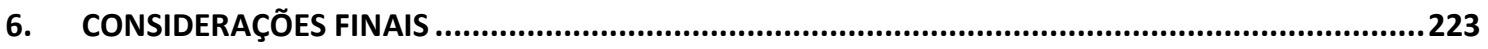

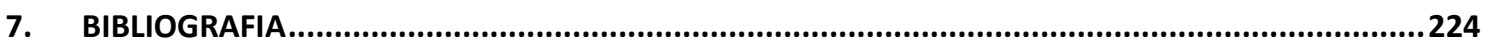


Tudo, aliás, é a ponta de um mistério. Inclusive, os fatos. Ou a ausência deles. Duvida? Quando nada acontece, há um milagre que não estamos vendo.

(João Guimarães Rosa, “O espelho”) 


\section{Introdução}

\subsection{Considerações históricas sobre o nheengatu}

\subsubsection{Origem e ascensão}

O nheengatu, também denominado língua geral amazônica ou tupi moderno, é uma língua que se desenvolveu historicamente do que hoje pode se chamar de tupi antigo, "a língua mais usada na costa do Brasil", segundo o padre José de Anchieta (1595/2014). Contudo, durante os dois primeiros séculos da colonização portuguesa, a língua descrita por Anchieta recebeu a designação língua brasílica (já no século XVI, mas, sobretudo, no século XVII). O termo "tupi" passou a ser corrente para se referir a esse idioma somente no século XIX. Segundo os relatos de Pero de Magalhães Gândavo e Fernão Cardim (apud NAVARRO, 2005, p. 11), essa língua era falada do Pará até o sul do país por índios tupiniquins, potiguaras, tupinambás, temiminós, caetés, tabajaras, tamoios, tupinaes etc. O tupi antigo, ou língua brasílica, deixou de ser falado no final do século XVII, após o que levou ao surgimento de duas línguas gerais ${ }^{1}$ : a língua geral do sul, também chamada de língua geral paulista ou língua geral meridional, que desapareceu no século XIX; e a língua geral do norte, chamada também de língua geral amazônica, posteriormente denominada nheengatu ${ }^{2}$, idioma ainda falado no Vale do Rio Negro, no estado do Amazonas (NAVARRO, 2016, p. 6).

A língua geral paulista teve a sua gênese no ambiente mestiço da capitania de São Paulo do século XVI, a partir do tupi falado em São Vicente e no Vale do Tietê (RODRIGUES, 1994, p. 102). Esse idioma espalhou-se por territórios que hoje pertencem a Minas Gerais, Goiás, Mato Grosso e norte do Paraná, e a sua expansão foi fruto, principalmente, das expedições bandeirantes, que adentravam as regiões mais interioranas do país em busca de mão de obra indígena. No entanto, já na primeira metade do século XVIII nota-se o enfraquecimento da língua geral paulista nessas regiões, visto que aumentava "o sangue reinol na população da capitania", devido ao descobrimento de ouro nas Minas Gerais, e enfraqueciam-se as entradas e bandeiras

\footnotetext{
${ }^{1}$ Há indícios de que uma terceira língua geral de base tupi tenha sido falada no sul da Bahia. Para mais informações sobre esse assunto, cf. LOBO et al. (2006).

${ }^{2}$ O termo nheengatu, cujo significado em tupi antigo é "língua boa" (de nhe'enga "língua" + katu "bom, boa"), começou a ser empregado no século XIX. Neste trabalho, em alguns momentos, utilizaremos como sinônimos os termos "língua geral amazônica" e "nheengatu".
} 
(HOLANDA, 1995, pp. 128-129). Os últimos registros de que temos notícia a respeito da língua geral paulista são do início do século XIX. Sérgio Buarque de Holanda relata que Hercules Florence, desenhista da expedição científica empreendida pelo barão Georg Heinrich von Langsdorff, entrou em contato com falantes da arrefecida língua geral paulista.

\begin{abstract}
Na província de São Paulo, onde chegou no ano de 1825, o próprio Florence pudera ouvir ainda a língua-geral da boca de alguns velhos. Não seria para admirar se isso se desse durante sua demora de mais de um semestre em Porto Feliz, distrito onde fora numerosa a mão-de-obra indígena [...] (HOLANDA, 1995, p. 130)
\end{abstract}

Além de Florence, Auguste de Saint-Hilaire também entrou em contato com falantes da língua ainda no século XIX. Estes são, até o presente momento, os dois últimos relatos de que temos conhecimento. Devido à escassez de materiais relacionados à língua geral paulista, torna-se muito difícil que estudos mais aprofundados sejam feitos a seu respeito, tanto em relação a seus aspectos linguísticos como em relação à sua história social ${ }^{3}$.

De acordo com o trabalho de José Ribamar Bessa Freire, a língua geral amazônica (doravante LGA) teve sua base geográfica no estado do Grão-Pará, e sua origem se deve inicialmente ao contato de colonos e missionários, vindos de Pernambuco e Maranhão, com os índios tupinambás que habitavam a região da Costa do Salgado ${ }^{4}$ em 1616. Esses colonos e missionários conheciam a língua brasílica, visto que nela se comunicavam com índios aliados que traziam consigo. Devido a isso, conseguiram se comunicar sem grandes dificuldades com o povo tupinambá da Costa do Salgado. Posteriormente, a língua empregada nessa região passou a ser utilizada no ambiente das aldeias de repartição ${ }^{5}$ e foi se expandindo por outros núcleos populacionais, o que propiciou o contato, por meio dos $\operatorname{descimentos}^{6}$ de índios de

\footnotetext{
3 Há pouco tempo uma dissertação de mestrado sobre a língua geral paulista foi defendida na Universidade Estadual de Campinas (UNICAMP). Para mais informações, cf. LEITE (2013).

${ }^{4}$ Região situada no litoral nordeste do atual estado do Pará.

${ }^{5}$ As aldeias de repartição eram os lugares onde índios de diferentes famílias linguísticas eram alocados. Lá, sob o comando de um colono luso, que detinha o título de "capitão de aldeia", eles podiam ser alugados ou concedidos a outros colonos. Nesse ambiente, os missionários eram os responsáveis pelo "governo espiritual" dos índios, que consistia em sua educação e catequese. Essa configuração foi observada entres os anos 1616 e 1686, depois desse período, após muitas disputas entre colonos e missionários para o controle da mão de obra indígena, os missionários, por meio do Regimento das Missões (1686), obtiveram o controle efetivo das aldeias de repartição (FREIRE, 2000, pp. 10-11).

${ }^{6}$ Descimento é o nome que se dá ao recrutamento de "índios bravios", entre os quais aqueles que não falavam a língua geral, que era a língua empregada na catequese, com o propósito de concentrá-los nas aldeias de repartição (FREIRE, 2011, p. 120).
} 
diversas etnias aos aldeamentos jesuítas, entre línguas faladas por índios de filiação tupi e não tupi, tornando-a assim uma língua de comunicação interétnica (FREIRE, 2011, p. 117).

Essa língua servia à comunicação interétnica porque era utilizada na comunicação entre índios de diferentes etnias, como também entre eles e os missionários e colonizadores europeus. No entanto, devido a esses contatos, algumas alterações tipológicas foram gradativamente diferenciando essa língua da língua brasílica e de sua variante dialetal falada pelos índios tupinambás da Costa do Salgado; passando-a, então, à condição de língua supraétnica, porque não era identitária de nenhuma etnia indígena, mas era utilizada por elas como língua veicular.

À medida que a LGA se alastrava a outras regiões, aumentando o número de pessoas que a falavam, ela passava a acumular novas funções sociais. Era ela a língua da catequese, a língua que os membros da Companhia de Jesus, nas aldeias de repartição, utilizavam para ensinar a doutrina católica aos povos nativos de diferentes línguas. Também foi a língua que os missionários utilizaram para a organização da força de trabalho indígena, bem como a empregada em relações comerciais. Assim, acumulando diversas funções, passou a ser uma língua de forte identidade regional, empregada inicialmente por falantes bilíngues, que falavam a língua relativa ao povo a que pertenciam (língua étnica, específica e de identificação de um povo) e a LGA (língua supraétnica, que servia à comunicação entre índios falantes de diversas línguas étnicas). No entanto, aos poucos, a LGA foi se tornando a única língua falada por povos destribalizados, que eram retirados de suas regiões de origem para integrar as aldeias de repartição, ou por aqueles que tinham as suas línguas extintas.

O uso da língua geral foi tão difundido que "sequer os filhos dos moradores lusitanos falavam o português, pois, entregues ao cuidado das amas de leite indígenas, com elas adquiriam a então denominada língua geral [...]” (FREIRE, 2011, p. 119). Nesse cenário, até a metade do século XVIII, o interesse da metrópole em deixar que as línguas gerais (língua geral amazônica e língua geral paulista) fossem faladas e amplamente difundidas pela colônia estava relacionado ao controle de uma extensa área territorial onde eram faladas muitas línguas étnicas de diferentes troncos linguísticos; ou seja, as línguas gerais, faladas por grande parte da população, indígena e não indígena, 
facilitavam a administração e garantiam a unidade política de um território multilíngue e multicultural. Segundo Bessa Freire:

Os portugueses fortaleceram as línguas gerais nos dois Estados que criaram em território americano - o Brasil e o Grão-Pará -, pois viabilizavam o projeto colonial, na medida em que permitiam uma comunicação mais ampla, contornando a necessidade de se conhecerem várias centenas de línguas particulares, que eram faladas em cada estado brasileiro. (FREIRE, 2011, p. 251)

Dessa forma, a LGA, do século XVII ao XVIII, expandiu-se por uma extensa área geográfica, da região-berço, a Costa do Salgado, até os sertões da Amazônia, tanto que:

[...] subiu os rios Amazonas e Solimões, galgou seus principais afluentes, infiltrou-se em vilas e povoações, ganhou as cidades, deu mostras de vitalidade e vigor, atingindo universalidade regional, na medida em que era usada por todos os indivíduos, incluindo portugueses e africanos, qualquer que fosse seu lugar na produção, seja como língua materna ou como segunda língua, em uma variedade de funções. (FREIRE, 2011, p. 171)

\subsubsection{Reveses e ocaso}

Após esse período de constante crescimento, a partir de meados do século XVIII, uma série de fatores fez com que a LGA fosse aos poucos se enfraquecendo, entrando em rápido declínio no século XIX e perdendo de vez, na passagem para o século XX, a sua hegemonia ao português na região amazônica.

Já na primeira metade do século XVIII começaram a surgir as primeiras proibições de uso da LGA, no momento em que afloravam as divergências entre os missionários e a administração colonial sobre os critérios utilizados na repartição dos índios (FREIRE, 2011, p. 122). Como esses missionários dominavam a língua geral, o que não se observava entre os membros da Coroa portuguesa, eles obtinham vantagens em relação ao controle da mão de obra indígena concentrada nas aldeias de repartição (FREIRE, 2011, p. 123). O fortalecimento político e econômico da Companhia de Jesus, devido em grande parte ao domínio linguístico que tinham da língua mais falada na colônia, incomodava muito os interesses da Coroa portuguesa. Assim, as línguas gerais passavam agora a ser vistas por Portugal como uma ameaça ao controle da colônia e um grande óbice ao desenvolvimento da língua portuguesa, a língua da metrópole, que após 
dois séculos e meio de colonização ainda não era corrente na maior parte do Brasil, sobretudo na região do Grão-Pará.

No entanto, essas primeiras medidas restritivas não surtiram efeitos imediatos e a LGA continuou a se expandir. Nesse período, a medida mais taxativa foi a implementação do Diretório que se deve observar nas povoações dos índios do Pará e Maranhão, assinado em 3 de maio de 1757 por Francisco Xavier de Mendonça Furtado, irmão do Marquês de Pombal (FREIRE, 2011, p. 126). Esse projeto visava minar as forças da Companhia de Jesus para promover a secularização da administração colonial; assim, encaminhava a expulsão dos missionários jesuítas, que tinham perdido o controle administrativo dos aldeamentos, e passava estes aos cuidados de leigos - colonos, civis e militares -, que ganhavam o título de "diretores dos índios" (NAVARRO, 2012, p. 246). Com isso, o uso da língua geral foi proibido mediante a justificativa da uniformização cultural na colônia, que passava, então, a ter como oficial a língua portuguesa.

Com o intuito de rapidamente "portugalizar" a Amazônia, medidas como o incentivo à imigração lusa, com o fito de aumentar a quantidade de portugueses em relação à de índios, foram incentivadas pelo Marquês de Pombal (FREIRE, 2011, p. 127). Ademais, com o incentivo aos casamentos mistos e com a educação escolar em língua portuguesa, a língua oficial deveria fortalecer-se na região (FREIRE, 2011, p. 128). No entanto, nenhum projeto conseguiria frear de forma abrupta o uso de uma língua já consolidada e predominante em uma vasta região, assim "o projeto fracassou, registrando-se apenas o início da penetração lenta da língua portuguesa na parte oriental [...] enquanto na Amazônia ocidental [...] a língua geral permaneceria por mais um século ainda como língua franca" (FREIRE, 2011, pp. 129-130).

Entretanto, na primeira metade do século XIX, a predominância da língua geral na Amazônia sofria um sério revés. Nesse período deu-se o duro contra-ataque das tropas imperiais à Cabanagem, revolta popular iniciada no Pará durante o período regencial (1831-1840). Durante esses conturbados anos de instabilidade política, outros movimentos populares também se rebelavam contra o governo regencial, entre eles destacam-se a Sabinada, na Bahia, entre 1837 e 1838, e a Revolução Farroupilha, no Rio Grande do Sul, entre 1835 e 1845. A perseguição aos cabanos durou cinco anos 
(1835-1840) e, como resultado disso, um quarto dos habitantes da província insurgente foi dizimado.

Na cabanagem, morreram 40 mil pessoas, ou seja, um quarto de toda a população recenseada do Grão-Pará, que compreendia a área dos atuais estados do Amazonas e Pará. O número de mortos - quase todos falantes de LGA - equivalia, na época, a toda a população da comarca do alto Amazonas. Os cabanos eram, em sua maioria, tapuios e, portanto, falantes de língua geral, geralmente na condição de monolíngues. (FREIRE, 2011, p. 244)

Com o fracasso da Cabanagem - "a última oportunidade histórica de sobrevivência de uma sociedade tapuia" ${ }^{\text {- }}$, inicia-se o processo de declínio da LGA (FREIRE, 2011, p. 244).

Outro forte golpe sofrido pela LGA ocorreu durante a Guerra do Paraguai (18641870). A província do Amazonas, proporcionalmente às outras províncias do Império, foi a que mais enviou homens para esse conflito. O recrutamento dos índios se deu de modo extremamente violento, já que a maior parte deles foi apresada e obrigada a combater em terras paraguaias. Isso levou à morte de quase todos os falantes de LGA que para lá foram enviados na condição de "voluntários” da Pátria.

\begin{abstract}
De 1865 a 1868 , foram enviados um total de 2.070 homens, dos quais 746 eram "voluntários" dos municípios do baixo Amazonas e 1.324 da província do Amazonas. [...] Mais de 1.250 falantes de língua geral - homens, adultos, muitos deles monolíngues - ficaram sepultados em terras paraguaias. (FREIRE, 2011, p. 245)
\end{abstract}

Além desses dois eventos que contribuíram com a diminuição do número de falantes de LGA, houve desde meados do século XVIII, como já vimos, políticas que incentivaram a ocupação da região amazônica por falantes de língua portuguesa. Contudo, isso se tornou mais consistente com a crescente urbanização, com o aumento das escolas primárias na província do Amazonas - ambiente em que somente a língua portuguesa era ensinada e o uso da LGA era proibido - e com a mudança do tipo de transporte.

Em Belém e Manaus, às vésperas da independência do Brasil (1822) e da adesão do Estado do Grão-Pará ao Estado do Brasil (1823), prevalecia o bilinguismo em LGA e português, que assim se manteve até o terceiro quartel do século XIX. A cada uma dessas línguas, determinados usos e espaços estavam reservados: "algumas práticas

\footnotetext{
7 O nome "tapuio" era atribuído ao índio que já não falava mais uma língua étnica e somente se comunicava em língua geral.
} 
estavam reservadas para a língua indígena - por exemplo, as mais informais e domésticas -, e as mais formais, geralmente relacionadas à escolaridade e à administração, para a língua oficial” (FREIRE, 2011, p. 206). Contudo, à medida que essas cidades foram se modernizando e crescendo, diminuía o número de falantes de LGA, que progressivamente deixavam de falá-la em decorrência do uso cada vez mais frequente da língua portuguesa ou que, sem se adaptar à nova realidade, abandonavam os núcleos urbanos em direção a regiões mais afastadas em que a LGA ainda prevalecia.

O projeto de escola imposto na região amazônica contribuiu nesse cenário, segundo dados de Francisco Bernardino de Souza (apud FREIRE, 2011, p. 203), “cada ano aumentava o número de escolas primárias públicas na província do Amazonas: elas eram 36 em 1873; passaram a 49 em 1876, e atingiram 109 em 1886, todas elas banindo do currículo qualquer referência à língua geral”.

Mais do que o aumento das escolas, o fator responsável pela alteração mais drástica na dinâmica das relações sociais na Amazônia foi a substituição das embarcações a remo pelos barcos a vapor, que facilitaram o acesso de migrantes e imigrantes falantes de português a diversas regiões amazônicas ao reduzir significativamente a duração das viagens. De acordo com Bessa Freire, toda a navegação no rio Amazonas até meados do século XIX era feita por meio de barcos a remo, o que dificultava enormemente os deslocamentos, sobretudo quando se tinha de remar contra a corrente, em direção a regiões do alto Amazonas. Nessa época, levava-se “cerca de três meses para completar um percurso de $1.500 \mathrm{~km}$, de Belém a Manaus, na foz do rio Negro, ou até cinco meses, dependendo do tipo de embarcação e da época do ano" (FREIRE, 2011, p. 246).

A mudança do sistema tradicional de navegação para as embarcações a vapor, metonimicamente chamadas de "vapores", favoreceu a inserção da língua portuguesa em ambientes em que a LGA desempenhava diversas funções sociais, alterando, consequentemente, a economia e a cultura da região. Segundo um relato do naturalista inglês Henry Walter Bates (apud FREIRE, 2011, p. 246), com a implementação de uma linha de vapores em 1853, a mesma viagem que antes chegava a durar até cinco meses era feita agora em qualquer época do ano em apenas oito dias. 
O número de "vapores" de comércio aumentava à medida que Belém e Manaus passavam a se integrar cada vez mais ao restante do país, devido principalmente à demanda da borracha no mercado internacional.

O número de vapores de comércio no rio Amazonas, que em 1851 era de apenas três, subiu para 12 em 1860, e em 1888 já era superior a cem, de todos os tamanhos. Havia ainda grandes vapores da linha brasileira, que faziam quatro viagens mensais ao Rio de Janeiro, e duas linhas inglesas que ligavam Manaus com a Europa e os Estados Unidos, três vezes por mês cada uma delas. (MARAJÓ apud FREIRE, 2011, pp. 203-204)

Impulsionada pela exploração da borracha, a Amazônia vivia nessa época seu período de maior pujança econômica. Os interesses comerciais da nação estavam voltados para essa região, que atraia para o seu território o interesse de muitos trabalhadores motivados a melhorar suas condições de sobrevivência. Foi assim que esses vapores "trouxeram cerca de 500 mil nordestinos, no período de 1872 a 1910, distribuídos pelos seringais, vilas e povoações, todos eles portadores da língua portuguesa (...)" (FURTADO apud FREIRE, 2011, p. 247). A grande leva de nordestinos que se destinava à região amazônica fugia da forte seca que assolava o nordeste brasileiro e flagelava seus habitantes.

Somente após esse período, na passagem do século XIX para o século XX, o português sobrepujou a LGA na Amazônia, decretando o ocaso da língua e a perda irreparável no número de seus falantes.

\subsubsection{O nheengatu nos dias atuais}

Atualmente, os falantes de nheengatu concentram-se sobretudo no Vale do Rio Negro, espaço em que originalmente não havia sido falada nenhuma língua de base tupi. Essa língua é observada em regiões do Alto Rio Negro, onde possui por volta de 6 mil falantes espalhados no Brasil (na região conhecida como "Cabeça do Cachorro"), na Venezuela e na Colômbia. Também se notam em outras regiões da Amazônia, em número bem mais reduzido, a presença de alguns falantes, como no Baixo Rio Madeira e nos rios Andirá e Maraú, na região do Médio Amazonas (ÁVILA, 2016, p. 20). 
Desde 2002, pela lei 145/2002, juntamente com as línguas tukano e baniwa ${ }^{8}$, é idioma cooficial ao português no município de São Gabriel da Cachoeira ${ }^{9}-$ AM. No entanto, a oficialização dessas três línguas, até o presente momento, aconteceu mais em um plano simbólico do que prático. O fato de essas línguas não ocuparem o mesmo espaço da língua portuguesa nas repartições públicas, visto que os documentos municipais ainda não foram traduzidos para elas, e de serem ensinadas em poucas escolas públicas da cidade corrobora o que foi dito.

O nheengatu, também falado no núcleo urbano do município de São Gabriel da Cachoeira - AM, tem sua predominância em comunidades às margens do Rio Negro, lugares em que o português é a segunda língua de muitos falantes.

Em relação às escolas, o nheengatu, ainda que ensinado em poucas escolas do núcleo urbano de São Gabriel da Cachoeira, é ensinado com maior frequência em comunidades à beira do Rio Negro, as quais integram a área do mesmo município. $\mathrm{Na}$ cidade, o seu ensino assemelha-se ao de uma língua estrangeira, visto que o nheengatu compõe um quadro de disciplinas que são ministradas em português; em muitas comunidades, diferentemente, o nheengatu, sobretudo nos primeiros anos de alfabetização, é a língua em que todo o conteúdo escolar é transmitido, e, nesses ambientes, é o ensino da língua portuguesa que se assemelha ao de uma língua estrangeira.

No entanto, isso não vale como regra, pois há muitas diferenças entre as várias comunidades do Alto Rio Negro. Além disso, os professores - falantes de nheengatu ou não - que lecionam nessas comunidades trabalham, muitas vezes, em esquema de rodízio. Por exemplo, quando um professor que não é falante de nheengatu vai a uma comunidade onde este é a primeira língua de seus moradores, suas aulas são oferecidas em português. Isso ocorre, em geral, após as crianças já terem passado pelo período de alfabetização em nheengatu. Assim, na maioria dessas escolas, o ensino do português se dá após o ensino do nheengatu, ainda que em algumas comunidades, antes desse período, as crianças já tenham tido, em graus de exposição variados, algum contato com a língua portuguesa.

\footnotetext{
${ }^{8}$ Línguas faladas por índios das etnias tukano e baniwa.

${ }^{9}$ No município de São Gabriel da Cachoeira, cuja área supera o território de Portugal, são faladas, por 23 etnias, 18 línguas diferentes.
} 
Como nessas escolas, tanto do núcleo urbano como das comunidades de São Gabriel da Cachoeira, o nheengatu é ensinado com escassos recursos - carecendo-lhes de materiais didáticos básicos como cartilhas de alfabetização e livros infantis -, o seu ensino, principalmente da modalidade escrita, é muito precário. Assim, a utilização dessa língua, que sobrevive desde sua formação basicamente pela oralidade, tende a se enfraquecer, pois, à medida que seus falantes cada vez mais rápida e intensamente passam a integrar a cultura de língua portuguesa, na qual a perpetuação do idioma e a transmissão de informações por meio da escrita gozam de prestígio, o nheengatu, por não se encontrar em condições de igualdade, perde forças para o português e, com isso, o bilinguismo ${ }^{10}$ tão frequente nessa região corre o risco de em gerações futuras deixar de existir. Devido a isso, caso nenhuma medida seja tomada no intuito de melhorar essas condições, é possível que o nheengatu continue a se enfraquecer até deixar de ser falado em toda a Amazônia.

Somado ao que já foi dito, além de medidas políticas que muito oprimiram o uso dessa língua e, consequentemente, seus falantes, o nheengatu encontra-se ameaçado também por não estar atrelado ao progresso e às inovações do mundo contemporâneo. Os efeitos dessa concepção historicamente construída e alimentada, que inferioriza as línguas indígenas e seus falantes frente ao idioma luso (do colonizador) e à cultura europeia (que tenta se impôr), são sentidos até os dias atuais. Não é à toa que, hoje em dia, por exemplo, muitos desses falantes, principalmente os jovens citadinos, influenciados por veículos de comunicação em massa, como a televisão e, mais recentemente, a internet, sentem-se estimulados a utilizar mais frequentemente a língua portuguesa, uma vez que o nheengatu não integra tais espaços. Com isso, partilhando de valores e referências culturais propagados pelos grandes centros econômicos do eixo Sul-Sudeste do país e sentindo-se envergonhados de sua língua indígena e das referências culturais relacionadas a ela ${ }^{11}$, esses falantes passam a rejeitar o bilinguismo ao abnegar a herança histórica e a cultura tradicional veiculadas pelo idioma indígena em razão do uso exclusivo da língua portuguesa.

\footnotetext{
${ }^{10} \mathrm{O}$ bilinguísmo nessa região se configura basicamente pelo conhecimento de uma língua indígena mais a língua portuguesa. Há, contudo, devido ao contato entre falantes de diferentes línguas indígenas, pessoas que falam várias delas.

${ }^{11}$ A questão da vergonha, em minha opinião, está atrelada à falta de prestígio das línguas indígenas em comparação à língua portuguesa. Prestígio este relacionado a muitas questões sociais, envolvendo motivações políticas e de dominação cultural, que tiveram origem no período colonial.
} 
Nesse cenário desfavorável à língua mais falada em toda a Amazônia por mais de duzentos anos, mantenedora de um repertório cultural riquíssimo em lendas, mitos, contos e cantigas, iniciativas com a pretensão de revitalizá-la vêm sendo desenvolvidas.

Entre elas, podemos mencionar a criação, em 2009, da cadeira de nheengatu na Universidade de São Paulo (USP), projeto pioneiro entre as universidades brasileiras. Desde então, a elaboração de materiais - como cartilhas de alfabetização, traduções de obras literárias e um dicionário nheengatu-português/português-nheengatu - vêm sendo desenvolvida nesta mesma universidade, a fim de contribuir para a reversão do cenário linguístico em que se encontra o nheengatu nos dias atuais. Assim, esta pesquisa de mestrado insere-se em tal projeto maior e almeja contribuir para a revitalização linguística do nheengatu nas regiões do Alto Rio Negro.

\subsection{Por que traduzir a obra Le Petit Prince ao nheengatu?}

Para responder a essa pergunta, é preciso separá-la em outras duas questões: por que traduzir a história do pequeno príncipe ao nheengatu? Por que traduzir uma obra em língua francesa ao nheengatu?

A resposta à segunda pergunta, de fato, é muito simples e relaciona-se à escolha da obra. A tradução de uma obra francesa não foi algo pensado a priori, o que se pensou de antemão foi a escolha do enredo que seria traduzido. Como o tradutor desta empresa conhece a língua francesa, a opção pelo título original, em francês, se deu com o propósito de evitar a tradução ao nheengatu a partir do texto traduzido em português ${ }^{12}$.

Com relação à primeira questão, a escolha da história do pequeno príncipe visou principalmente aos dois públicos a que se destina a proposta de tradução contida nesta dissertação: às escolas de São Gabriel da Cachoeira e aos alunos das disciplinas Tupi III e Tupi IV, oferecidas na Universidade de São Paulo, nas quais o nheengatu é estudado.

A tradução de uma obra infantojuvenil parece se adequar bem aos dois públicos mencionados, tanto aos alunos em idade escolar como aos alunos universitários incipientes no idioma. Ao primeiro grupo, a escolha do enredo do pequeno príncipe foi 12 Agradeço à sugestão da professora Adriana Zavaglia na disciplina Introdução aos Estudos
Tradutológicos para que eu realizasse a tradução diretamente do francês ao nheengatu. 
motivada por nele se ressaltar a sabedoria das crianças e por se valorizarem a amizade e a fértil imaginação infantil, elementos incentivados no ambiente escolar. No livro de Exupéry, as crianças são apresentadas como mais sábias do que os adultos. Estes, por não serem mais crianças, passaram a se preocupar com outros assuntos, julgados por eles mais importantes do que as brincadeiras de criança. Um quadro esquemático que ilustra, a partir do desenvolvimento da narrativa, as diferenças entre crianças e adultos pode ser assim apresentado:

\begin{tabular}{|l|l|}
\hline Crianças & Adultos \\
\hline Essência & Aparência \\
\hline Ser & Ter \\
\hline Emoção & Razão \\
\hline Felicidade & Infelicidade \\
\hline
\end{tabular}

Quadro 1: Diferenças entre crianças e adultos em Le Petit Prince

Parece ser a proposta desse livro, além de alertar às crianças que cresçam sem se esquecer da ingenuidade e espontaneidade que possuem, criticar o modo de vida de muitos adultos, movido pela vaidade, egoísmo e futilidade.

Além da importância conferida aos elementos já citados, é valido ressaltar a condenação de hábitos autodestrutivos, como o alcoolismo. Há um capítulo em que o principezinho chega a um asteroide habitado por um bêbado, que pouco fala e sente-se envergonhado por sempre estar embriagado. A ilustração de uma personagem infeliz e taciturna, devido ao vício, também é um elemento útil à educação e à formação promovidas no ambiente escolar.

Além das justificativas em relação ao enredo, tanto para os alunos das escolas de São Gabriel como para os alunos da Universidade de São Paulo, a tradução de uma obra ao nheengatu mostra-se proveitosa para pô-los em contato com os mecanismos da língua - léxico, sintaxe, morfologia e fonética/fonologia. Em ambas as situações o ambiente em que o nheengatu é estudado contará com mais um material a ser lido. 


\subsection{A tradução como instrumento de revitalização linguística}

\subsubsection{A tradução como enriquecimento da língua-alvo}

Traduções com o intuito de fortalecer a língua e a cultura de destino podem ocorrer de diversas maneiras. Entre os vários exemplos que aqui poderiam ser mencionados, serão destacadas a importância para os romanos das traduções feitas do grego ao latim e a consolidação do alemão como um vernáculo a partir da Bíblia de Lutero.

Não há como entendermos o conceito de tradução para os romanos, de acordo com os preceitos de Cícero e Horácio, se não o associarmos à atividade da imitação. Nas palavras de Susan Bassnett: "a tradução é uma forma de imitação no conceito romano de produção literária", sabendo-se que o tipo de imitação a que a autora se refere concerne à tradução de recursos estilísticos e não se coaduna à ideia de um tradutor subserviente ao texto-fonte (2003, p. 84).

Na Roma Antiga, como boa parte dos leitores era capaz de ler os textos traduzidos do grego para o latim também na língua-fonte, o que diferenciava uma tradução de outra não era o seu acesso ao conteúdo do texto de origem, mas o trabalho estilístico empregado pelos tradutores no texto-meta. Essa situação conferia ao trabalho tradutório relativa liberdade em relação ao texto-fonte, mas também o expunha a julgamentos do público leitor sobre as escolhas tradutológicas nele empreendidas (BASSNETT, 2003, pp. 83-84).

Com o trabalho estilístico dos tradutores romanos, almejava-se enriquecer as potencialidades discursivas da língua latina através de traduções de textos gregos e, até mesmo, suplantá-los na diversidade e beleza de recursos linguísticos: "para Cícero e Quintiliano, e principalmente para Plínio, o Jovem, a tradução era um exercício retórico, cujo objetivo era rivalizar com a língua grega e sobrepujá-la” (ESTEVES, 2014, p. 83). Para Bassnett, "o princípio subjacente de enriquecer a língua e a literatura nativas através da tradução fez com que a ênfase fosse colocada nos critérios estéticos do produto na língua de chegada e não nas noções mais rígidas de "fidelidade"” (2003, p. $82)$. 
Durante séculos, "o Latim foi a língua do sistema educativo em toda a Europa", e a tradução, servindo ao estudo da retórica, relacionava-se a exercícios de escrita mediante os quais o estilo oratório era aprimorado:

Porém, o aparecimento de literaturas nas línguas vernáculas a partir do século $\mathrm{X}$ conduziu a nova mudança no papel da tradução [...] Como em toda a Europa começaram a aparecer literaturas com pouca ou nenhuma tradição escrita própria que pudesse alimentá-las, as obras produzidas noutros contextos culturais eram traduzidas, adaptadas e absorvidas em grande escala. A tradição adquiriu uma dimensão adicional quando os escritores puseram o seu talento ao serviço da tradução como meio de elevar o prestígio da sua própria língua vernácula. Assim, o modelo romano de enriquecimento pela tradução tomou uma nova forma. (BASSNETT, 2003, pp. 93-94)

A importância das traduções para a língua alemã, consolidando-a e propiciando a formação de uma sociedade letrada no idioma vernáculo, insere-se nesse novo contexto histórico.

"A Bíblia de Lutero é considerada um texto fundador da língua e da cultura alemãs" (ESTEVES, 2014, p. 234). Lutero foi o responsável por dar forma ao que seria posteriormente a língua literária da Alemanha: "na época, o alemão tinha muitos dialetos, e Lutero conseguiu unificar e consolidar a língua alemã em seu texto bíblico" (BERMAN apud ESTEVES, 2014, p. 234).

O processo de elaboração desse texto está relacionado ao surgimento do Protestantismo na Europa, visto que a sua função era propiciar o contato "direto" entre a palavra divina e os fiéis. Como, nessa época, a tradução de um texto sagrado a uma língua vernácula era proibida, tornava-se necessário à sua "revelação" o intermédio de autoridades eclesiásticas. Nesse contexto, Lutero mostrou-se um ferrenho contestador da infalibilidade papal, tanto o é que foi excomungado pela Igreja Romana.

Em sua Carta aberta sobre a tradução, rebate veementemente as críticas dos papistas, a quem chama de asnos, sobre as escolhas tradutológicas que fez em sua tradução do Novo Testamento, do latim ao alemão. Em uma passagem dessa carta, ao justificar o acréscimo de uma palavra em sua tradução, atitude condenada pelos papistas, afirma ter priorizado o sentido do seu texto, porque o escrevia em alemão, não em latim nem em grego (LUTHER, 1530/2006, p. 103). Para ele, escrever em "bom alemão" era escrever conforme o uso habitual do idioma, o uso mais "natural aos ouvidos", sem que houvesse prejuízo para o entendimento claro de seu público-alvo. Isso fica patente quando afirma: 
Pois não se tem que perguntar às letras na língua latina como se deve falar alemão, como fazem os asnos, mas, sim, há que se perguntar à mãe em casa, às crianças na rua, ao homem comum no mercado, e olhá-los na boca para ver como falam e depois traduzir; aí então eles vão entender e perceber que se está falando em alemão com eles. (LUTHER, 1530/2006, p. 103)

Assim, a partir de suas considerações inseridas nesse contexto específico, entende-se que a tradução não deve ficar presa ao texto-fonte - sua realização não deve se dar de acordo com os idiomatismos da língua de origem - e que é imprescindível realizá-la com os olhos voltados à língua de destino e às pessoas que irão lê-la.

Com isso, em linhas bem gerais, a partir desses dois exemplos percebe-se, por meio de semelhanças e diferenças, a importância do fazer tradutório para os romanos e para os alemães. Algumas noções que foram aludidas acima são muito importantes ao projeto tradutológico empreendido neste trabalho, o qual, a partir de agora, será mais bem explicitado.

Destaco, como ponto de partida, a importância da atividade tradutória para que se explorem recursos linguísticos e estilísticos de uma língua com pouca tradição escrita e com baixo prestígio em relação à língua da qual se traduz. Pelo fato de a língua francesa possuir uma consolidada tradição escrita, buscarei na tradução do livro Le Petit Prince, de Antoine de Saint-Exupéry, do francês ao nheengatu, a partir de minha leitura e interpretação, apreender a expressividade presente no texto-fonte e adaptá-la às características da língua e do ambiente a que esta tradução se destina. Para isso, procurarei fazer uso de variados recursos linguísticos e estilísticos em nheengatu (presentes em narrativas já coletadas e escritas nessa língua e na modalidade oral da mesma, utilizada nos dias atuais) com a intenção de, como fizeram os tradutores romanos, escolher estratégias tradutológicas que propiciem o trabalho com as formas e a expressividade da língua-alvo.

Somado a isso, é muito importante que a língua falada pela população rionegrina seja observada atentamente, assim como o fez Lutero em relação aos falantes de alemão de sua época, a fim de que o texto-meta não "soe estranho" ao público-alvo. No entanto, além dessa importante atividade de conhecimento da língua em uso, na tradução que proponho procurarei resgatar termos que caíram em desuso devido à frequente substituição do léxico em nheengatu por empréstimos da língua portuguesa. Evidentemente, almeja-se com isso o equilíbrio entre a língua falada nos dias atuais e a 
recuperação de palavras em desuso - registradas na literatura ${ }^{13}$ e conferidas com falantes nativos da língua, sobretudo os mais idosos e experientes no idioma -, com a preocupação de não se construir um texto em uma variante lexical antiga, mas, ao mesmo tempo, de resgatarem-se, por meio de uma pesquisa lexical cuidadosa, algumas dessas palavras, para que a utilização da língua portuguesa fique reservada às situações em que a tradução por elementos lexicais em nheengatu mostrar-se "estranha" ou "artificial" aos falantes desta língua.

Essa postura não tem como pretensão condenar o contato entre o português e o nheengatu, bem como não defende o uso de um idioma em detrimento do outro. No entanto, devido às desiguais influências linguísticas e culturais que a língua portuguesa e o nheengatu exercem entre si, acredito que para a formação de uma língua de registro literário em nheengatu (inicialmente por meio de exercícios de tradução), diferentemente de Lutero, que procurou registrar a modalidade oral, mudando de status a língua alemã, seja benéfico o afastamento entre essas línguas, ainda que somente na escrita.

Para a visualização dessa situação de hibridismo entre o nheengatu e o português, analisemos um exemplo colhido da língua falada:

"Se manha ti upudei uiskrevei.

Minha mãe não pode escrever."

(CRUZ, 2011, p. 536, grifo meu)

Percebe-se nesse caso o léxico da língua portuguesa junto a morfemas do nheengatu - upudei e uiskrevei -, nos quais se utiliza o prefixo número-pessoal $u$-, relativo à terceira pessoa do singular ou do plural, com verbos em português adaptados ao sistema fonético-fonológico do nheengatu. Contudo, a utilização do léxico em nheengatu no período a seguir seria perfeitamente compreendida por seus falantes: se manha ti umupinima-kwaw (minha mãe não pode escrever) ${ }^{14}$. Da mesma forma que se

13 Constam dos materiais que utilizamos narrativas, gramáticas, vocabulários e dicionários em nheengatu, todos do final do século XIX e início do XX.

${ }^{14}$ A palavra manha (mãe) é um decalque da língua portuguesa há muito tempo utilizado em nheengatu. Em tupi antigo, a palavra que traduz "mãe" é sy, esta somente ocorre em nheengatu em formas cristalizadas oriundas daquela língua, como em kurasi (sol), de kó (este) + 'ara (dia) + sy (mãe) = kûarasy 
viu no exemplo acima o registro escrito de verbos colhidos da língua falada, poderiam ser citados muitos outros encontrados em textos escritos, como: valeri, uzari, kunheseri, gustari, pintari etc. ${ }^{15}$

Diferentemente desse hibridismo, minha proposta de tradução assemelha-se a projetos que já foram realizados em traduções para o guarani ${ }^{16}$, língua da família tupiguarani que possui muitas semelhanças linguísticas e culturais com o nheengatu. Esta é a língua com o maior número de falantes no Paraguai ${ }^{17}$ e, por muitos deles, é falada com muitas influências do castelhano, o que fê-la receber nesses casos a designação jopará, cujo significado é "mescla, mistura" em guarani. "Ao guarani paraguaio incorporaramse de 4.500 a 5.000 palavras castelhanas, cifra que se compara com o total de palavras contidas no clássico ‘Tesoro de la Lengua Guarani’, de Ruiz de Montoya, de meados do século XVII, obra que apresenta o guarani clássico” (NAVARRO, 2004, s/ pág.).

A fim de ilustração, analisemos o excerto a seguir, trecho de um diálogo coletado no Paraguai:

\section{"A- La eskuela ndachegustai.}

La escuela no me gusta.

\section{B- Ogustapa chupe la klase?}

Le gusta a el la clase?"

(NAVARRO, 2004, s/ pág., grifo meu)

A presença do castelhano mesclado à língua guarani está bem nítida nesse excerto, percebida pela utilização do artigo "la", pelas formas guaranizadas dos substantivos "escuela" e "clase" e pelo verbo "gustar".

(mãe deste dia). A palavra sy também significa "origem", assim kûarasy (origem deste dia) (NAVARRO, 2013, p. 236).

${ }^{15}$ Estas são as formas adaptadas dos seguintes verbos em português: valer, usar, conhecer, gostar e pintar.

16 O guarani, em 1992, foi declarado idioma oficial do Paraguai junto ao espanhol. Também é língua falada na província de Corrientes, na Argentina, onde foi oficializada em 2004. Em 2006 tornou-se língua oficial do Mercosul, estando legalmente em condições de igualdade com o espanhol e o português. Desde 2009, é um dos vários idiomas oficiais da Bolívia. No Brasil, desde 2010, junto ao português, é língua oficial do município de Tacuru, em Mato Grosso do Sul.

17 O guarani paraguaio também recebe as designações criollo, jopará, avañeẽ e moderno. Na Bolívia, falado por um grupo específico, recebe o nome chiriguano. Além desses, há ainda os dialetos tribais mbyá, nhandeva e kayová, falados por indígenas que vivem em comunidades do Paraguai, Brasil, Argentina e Uruguai (FREIRE, 2009, p. 330). 
Vejamos agora um exemplo de um texto escrito:

"Eremi Pedro orregala hague ndeve plata.

Dice que Pedro te regaló dinero."

(ORTIZ apud NAVARRO, 2004, s/ pág., grifo meu)

No exemplo acima identificamos o verbo "regalar" e o substantivo "plata". No entanto, de acordo com o dicionário guarani-espanhol/espanhol-guarani Ñe'êryru (CANESE \& ALCARAZ, 1997), todas essas ocorrências lexicais podem ser vertidas ao guarani: "escuela" mbo’eharóga; "clase" mbo'eha; "gustar" ha'ã; "regalar" jopói; "plata" pirapire, viru.

Ainda que na modalidade oral do guarani paraguaio seja frequente a presença de palavras castelhanas; em sua modalidade escrita, alguns de seus tradutores optaram por priorizar/valorizar o léxico guarani, com o propósito de conferir maior autonomia a esta língua, fortalecendo-a por meio de traduções de obras literárias, nas quais palavras em desuso passaram a ser novamente utilizadas e neologismos foram criados. Nesse âmbito de enriquecimento da língua e da cultura de chegada, podemos citar a tradução da obra Platero y yo (1914), de Juan Ramón Jiménez (escritor vencedor do prêmio Nobel de literatura em 1956), por Lino Trinidad Sanabria, com o título Platero ha che (1986). Esta foi a tradução pioneira de uma obra da literatura espanhola ao idioma guarani ${ }^{18}$. Além dessa obra, inserem-se nesse mesmo contexto a tradução do livro Le Petit Prince (1943), com o título Mitãmi (2005), pelos tradutores De Las Nieves Domínguez e Enrique Chamorro e, mais recentemente, a tradução da primeira parte de Don Quijote de la Mancha, El ingenioso hidalgo don Quijote de la Mancha (1605), obra composta por Miguel de Cervantes e traduzida por Félix de Guarania, com o título Kuimba'e katupyry ño Quijote yvyũngua (2013).

Félix Giménez Gómez, mais conhecido como Félix de Guarania, talvez tenha sido o tradutor mais profícuo da língua guarani. Entre as suas contribuições para o fortalecimento desta língua, há muitas traduções de obras de diversos autores de grande relevância para a literatura espanhola e mundial. Além da obra máxima de Cervantes, de

\footnotetext{
${ }^{18} \mathrm{~A}$ título de curiosidade àqueles que quiserem ler a declaração de interesse linguístico concedida pela Secretaria de Políticas Linguísticas da República do Paraguai à edição bilíngue Platero ha che, versão guarani de Platero y yo, realizada pelo escritor Lino Trinidad Sanabria, cf.: http://www.portalguarani.com/571_lino_trinidad_sanabria/25941_platero_ha_che_version_guarani_ de_lino_trinidad_sanabria.html. Acesso em 09/10/2015.
} 
Guarania também traduziu, entre outros, autores como Esopo, Shakespeare, Molière, Bécquer, Maiakovski, García Lorca e Pablo Neruda. Além dos autores supracitados, traduziu ao guarani fragmentos da Bíblia, o Hino Nacional Paraguaio e foi um dos tradutores oficiais da Constituição Nacional do Paraguai, além de ser autor de poemas, contos, peças teatrais, gramáticas e dicionários nesta língua ${ }^{19}$.

O seu empenho e a sua proposta de enobrecimento da língua guarani, afirmandoa grande, expressiva e independente das influências da língua castelhana, estão bem claros em suas declarações sobre a importância de sua atividade como tradutor:

Con las traducciones pretendo demostrar que el guaraní es una lengua que vale, que está en condiciones de reflejar los sentimientos y los pensamientos que se dan en los otros idiomas. Que nosotros no estamos atrás de los idiomas, el guaraní es un idioma actual, desarrollado, solo que nosotros lo hemos marginado, lo hemos dejado atrás, no le hemos cuidado y resultó que por obra y gracia de nosotros mismos, lo hemos empobrecido, lo hemos mezclado ensuciándolo. Porque el guaraní no necesita de ese jopará, de ese jehe'a que es una barbaridad, ninguna otra lengua tiene el problema que nosotros tenemos. ${ }^{20}$

Se pudéssemos dialogar com Félix de Guarania, acrescentaríamos que o nheengatu, bem como outros exemplos, também é uma língua em que a mescla entre idiomas se faz evidente. No entanto, não cabe a este trabalho assumir tom semelhante ao da declaração acima. Ainda que dela discordemos em alguns posicionamentos, com ela nos identificamos em relação à necessidade de emancipação entre as línguas para que a de prestígio social mais baixo possa ocupar o seu próprio espaço, sem que para isso dependa do idioma mais prestigiado ${ }^{21}$.

Exemplos como os que se seguiram mostram-nos a importância do registro escrito para o fortalecimento de uma língua, principalmente em ambientes em que a sua permanência encontra-se ameaçada. Assim, creio que traduções ao nheengatu possam contribuir no ambiente escolar do Alto Rio Negro, com a oferta de novos materiais, e

\footnotetext{
19 Àqueles que quiserem conhecer algumas das obras de Félix de Guarania mencionadas acima, cf.: http://www.portalguarani.com/autores_detalles_obras.php?id=391. Acesso em 11/10/2015.

20 Disponível em: http://www.agenciadenoticias.org/paraguay-felix-de-guarania-adios-a-un-grande/. Acesso em 10/10/2015. Esta declaração originalmente foi concedida ao jornal paraguaio "La Nación" e publicada em 29/04/2007 com o título "Dentro de 50 años el guaraní será un recuerdo si no se cuida". ${ }^{21}$ Ainda que a língua guarani seja majoritária no Paraguai, vale a pena destacar que, somente em 1992, ela foi oficializada no país. No entanto, sua condição de língua oficial não lhe colocou no mesmo patamar que o castelhano, o idioma que predominou no ensino escolar, universitário e em âmbito cultural. Até hoje, por mais que já tenha ocupado espaços em que antes não se fazia presente (por exemplo: programas de televisão e sites da internet), o guarani ainda enfrenta preconceitos (também enfrentado por muitas línguas indígenas de diferentes países) que o veiculam à concepção de que se trata de uma língua com baixa expressividade, desatrelada da modernidade e em nada relacionada aos avanços econômicos.
} 
servir ao enriquecimento da língua-alvo, propiciando que nela surja uma tradição escrita, a fim de que, por meio dessa modalidade, uma produção literária própria possa vir a se formar.

\subsection{2. (In)fidelidades e adaptações à língua e à cultura de destino}

Vimos que tanto os romanos como Lutero se preocupavam em ajustar as suas traduções à língua para a qual traduziam. Se, para os romanos, o propósito da tradução consistia em superar o texto-fonte por meio do trabalho estilístico empregado no textometa, alçando, assim, a língua latina a um patamar mais alto que a língua grega; para Lutero, sua atividade como tradutor centrava-se na produção de um texto que, orientado pela língua oral, não ocasionasse prejuízo ao entendimento do público-alvo, falante de alemão, que, por não conhecer o latim, não era capaz de entrar em contato "direto" com o texto bíblico. Por mais que nesses dois exemplos as condições e os objetivos sejam bastante distintos, em ambos os casos nota-se a primazia dos tradutores em relação à língua de destino como estratégia de enriquecê-la, bem como do ambiente em que estão inseridas. Com esse propósito, os mencionados tradutores, em alguns momentos, viamse obrigados a se desprender dos textos de origem. Estariam eles, assim, sendo tradutores infiéis?

$\mathrm{Na}$ verdade, a pergunta que deveria se formular é: estariam eles sendo fiéis ou infiéis a quê? A questão da fidelidade em tradução pode ser pensada, entre outros modos, por meio da relação entre alteridade e identidade (AUBERT, 1993, pp.75-76). Em outras palavras, segundo Schleiermacher, o tradutor pode conduzir os leitores ao autor ou trazê-lo até eles (1813/2007). Mesmo Lutero, que tinha como proposta aproximar o texto bíblico dos falantes de alemão, em certos momentos traduziu-o, como ele mesmo disse em sua Carta aberta sobre a tradução, "segundo a letra"22. Para Aubert:

A fidelidade na tradução caracteriza-se, pois, pela conjuminação de um certo
grau de diversidade com um certo grau de identidade; ela será, não por
deficiência intrínseca ou fortuita, mas por definição, por essencialidade, um
compromisso (instável) entre essas duas tendências aparentemente

22 “[...] não abandonei completamente a letra, mas observei-a com grande cuidado junto a meus ajudantes, de maneira que, quando necessário, mantive-a e dela não me afastei tão livremente [...]" (LUTHER, 1530/2006, p. 111). 
antagônicas, atingindo a sua plenitude nesse compromisso e nessa instabilidade. (AUBERT, 1993, pp.75-76)

Não há, como se vê, um ponto de equilíbrio exato entre essas "duas tendências aparentemente antagônicas". Assim, ainda que uma tradução se afaste mais do que outra das convenções linguístico-culturais presentes no texto-fonte, adaptando-as às características da comunidade de leitores a que se destina, não há como julgá-la infiel ao texto de origem, visto que busca mantê-lo fiel às convenções linguístico-culturais que, no julgamento de seu tradutor, são as mais adequadas à cultura de destino.

Esse processo de assimilação à cultura de destino, chamou-o Lawrence Venuti de "domesticação". Para o autor:

Uma tradução sempre comunica uma interpretação, um texto estrangeiro que é parcial e alterado, suplementado com características peculiares à língua de chegada, não mais inescrutavelmente estrangeiro, mas tornado compreensível num estilo claramente doméstico. As traduções, em outras palavras, inevitavelmente realizam um trabalho de domesticação. (VENUTI, 2002, p. 17)

A domesticação de um texto estrangeiro estará sujeita à interpretação - "que varia de acordo com situações culturais diferentes em momentos históricos diferentes" (VENUTI, 2002, p. 156) - e à própria intencionalidade de seu tradutor, o que se comprova pelo fato de diferentes traduções de um mesmo texto apresentarem graus distintos de domesticação. No entanto, até mesmo as traduções mais domesticadoras estarão, em certa medida, relacionadas ao texto-fonte; se não o fosse assim, seria impossível estabelecer qualquer semelhança entre eles. Nas palavras de Paulo Henriques Britto:

De modo mais preciso, podemos dizer que na tradução cada movimento de autonomização é imediatamente submetido a novo confronto com a primeira fonte - o original - sendo não raro seguido de um movimento corretivo de aproximação (...) Podemos dizer, pois, que a primeira fonte, ou original, exerce um efeito de controle sobre a tradução: sempre que ela começa a se afastar demais do original, este a puxa de volta para perto dele" (1999, p. 251).

Um caso curioso relacionado à autonomização da tradução em relação ao textofonte, devido à necessidade de aclimatação ao repertório cultural do público a que se destina, foi relatado em um estudo da antropóloga Laura Bohannam, feito na década de 
1960, intitulado Shakespeare in the bush ${ }^{23}$. Nele, a pesquisadora discorre sobre o que aconteceu quando tentou apresentar o texto Hamlet, de Shakespeare, a uma tribo de nome Tiv, situada na Nigéria. Devido à surpresa da antropóloga diante da incompreensão dos Tiv a momentos do enredo de Hamlet que ela julgava universais, o texto de Bohannam, que fala sobre "diferenças culturais e os limites da comunicabilidade" (ESTEVES \& AUBERT, 2008, p. 136), põe em xeque o lugarcomum de que há grandes questões entendidas e compartilhadas igualmente por toda a humanidade. A situação apresentada mostra que nem tudo que parece óbvio a uma visão de mundo é entendido da mesma forma por quem integra outro contexto, no qual uma visão de mundo diferente é partilhada. Tratando-se da leitura e interpretação de textos e, por conseguinte, de traduções a partir destes, nada é universalmente óbvio, nada é universalmente evidente.

Sobre o livro Le Petit Prince, um exemplo de domesticação é a sua tradução para o guarani, cujo título é Mitãmi, palavra que em português pode ser traduzida por “criancinha”. Segundo o dicionário guarani-espanhol/espanhol-guarani Ñe'êryru (CANESE \& ALCARAZ, 1997), a acepção dada à palavra "príncipe" é mburuvicha guasu ra'y (filho do grande chefe), uma descrição que contempla a posição hierárquica ocupada por um príncipe, aquele que é filho do rei, o grande chefe. Ainda que essa descrição dicionarizada contemple aproximações semânticas com o conceito de "príncipe", talvez para os tradutores ela não alcance o mesmo efeito expressivo que Mitãmi. A recepção da imagem de uma criancinha dotada de enorme sabedoria, construída pelos leitores de guarani, se dará na unidade global do texto e atrelar-se-á ao efeito de sentido construído pela relação entre uma criança pequena de elevada sabedoria, em oposição aos adultos, pessoas grandes de baixa sabedoria, como se tamanho e sabedoria fossem grandezas inversamente proporcionais, por meio das quais se entende que as crianças são mais sábias que os adultos. Isso ganha força no contraste entre os termos mitã (criança) e yvypóra kakuaa guasu (pessoa grande; adulto):

Yvypóra kakuaa guasukuérape hasyete rehekombo'e hag̃ua, tekotevẽ katuete oñemyesakã porã ichupekuéra ha ome'ẽ kane'õ mitãnguérape.

\footnotetext{
${ }^{23}$ A referência a esse texto será feita por meio do seguinte trabalho: ESTEVES, Lenita Rimoli \& AUBERT, Francis Henrik. "Shakespeare in the bush" - história e tradução. In.: Tradução \& Comunicação - Revista Brasileira de Tradutores, no 17, 2008.
} 
(SAINT-EXUPÉRY/ DOMÍNGUEZ \& CHAMORRO, 2005, p. 10, grifo meu $)^{24}$

Vê-se assim a importância da palavra mitã à leitura que os tradutores do guarani fizeram da obra de Saint-Exupéry, tanto o é que ela intitula a tradução.

Contudo, não é apenas por dar título à tradução que essa escolha lexical mostrase importante. No momento em que os tradutores se depararam com a palavra "rei" (há um rei entre as personagens do livro), eles optaram por traduzi-la pela forma mburuvichaguasu (grande chefe), o que sugere que preferiram evitar associações entre o protagonista do livro e o posto ocupado e a função desempenhada por um rei. Para os tradutores do guarani, a acepção da palavra "príncipe", vinculada ao protagonista - le petit prince -, parece ser interpretada de modo mais simbólico do que efetivo, e isso se materializa em uma escolha lexical distinta para designá-lo - mitãmi, que favorece a leitura de que a nobreza da personagem não está relacionada à transmissão sanguínea, mas, sim, à sabedoria, ao conhecimento, ao modo de pensar.

Devido à grande diferença entre as representações culturais expressas pelo francês e pelo guarani, a adaptação foi uma das modalidades de tradução utilizadas pelos tradutores desta língua. Além da adaptação já mencionada (rei $\approx$ grande chefe), há, entre outras, uma em relação ao instrumento de trabalho do narrador do livro: o avião. Assim, “avião" foi traduzido por pepo'atã (literalmente: “asa dura”), à época, um neologismo em guarani. É interessante notar que avion e pepo'atã possuem abrangência semântica distinta, ainda que mantenham uma relação de contiguidade entre si. Por mais que o uso da palavra "avião" esteja dessemantizado em relação à palavra "ave", cuja etimologia remonta à forma latina avis, is "ave", "pássaro", a associação entre o meio de transporte e uma ave que voa com as asas fixas e rijas possibilitou em guarani a criação de pepo 'at $\tilde{a}^{25}$. Com essa estratégia de tradução, priorizou-se o uso de recursos linguísticos da língua-meta ao associá-los a elementos culturais manifestados por ela.

Por meio dessas breves considerações, percebe-se a acomodação do texto em guarani ao complexo linguístico-cultural no qual se insere. Muitas das escolhas linguísticas se justificam pelo conhecimento que se tem da cultura receptora, a qual

\footnotetext{
${ }^{24}$ Compare esse segmento com: "Les grandes personnes ne comprennent jamais rien toutes seules, et c'est fatigant, pour les enfants, de toujours et toujours leur donner des explications..." (SAINT-EXUPÉRY, 1999, p. 14, negrito meu) e "As pessoas grandes não compreendem nada sozinhas, e é cansativo, para as crianças, estar a toda hora explicando" (SAINT-EXUPÉRY/ BARBOSA, 2008, p. 8, grifo meu)

${ }^{25}$ O dicionário Ñe'ẽryru registra pepo'atã como neologismo: "pepo'atã. neol., s. Avión, aeroplano" (CANESE \& ALCARAZ, 1997).
} 
fornece informações relevantes para a tomada de decisões no ato tradutório. Nesse sentido, para que o texto de partida seja conduzido a um novo contexto cultural, a competência tradutória "remete forçosamente para frente, quer dizer, para a reflexão preparatória que visa à recepção" (AZENHA, 2010, p. 41). Isso não se contrapõe, como expõe Azenha, a um olhar retrospectivo em direção ao texto-fonte para que o textoobjeto da tradução seja recontextualizado e a leitura empreendida por seu tradutor seja validada (2010, p. 55).

Outro exemplo que insere a obra de Saint-Exupéry em um contexto cultural bem distinto do original é a sua adaptação à literatura de cordel. No projeto empreendido pelo cordelista Josué Limeira e pelo ilustrador Vladimir Barros, o discurso em prosa cede lugar às sextilhas (estrofes compostas por seis versos) e os recursos sonoros obtidos pela métrica e pela rima particularizam essa adaptação à cultura de algumas regiões do nordeste brasileiro.

Lorsque j'avais six ans j'ai vu, une fois, une magnifique image, dans un livre sur la forêt vierge qui s'appelait Histoires vécues. Ça représentait un serpent boa qui avalait un fauve. Voilà la copie du dessin. (SAINT-EXUPÉRY, 1999, p. 13)

Certa vez, quando tinha seis anos, vi num livro sobre a Floresta Virgem, Histórias vividas, uma impressionante gravura. Ela representava uma jiboia engolindo um animal. Eis a cópia do desenho. (SAINT-EXUPÉRY/BARBOSA, 2008, p. 7)

Li um livro sobre florestas virgens

Aos seis anos de idade

Uma jiboia engolia um bicho

Com toda voracidade

Eis a cópia do desenho

Mostrando a fatalidade. (SAINT-EXUPÉRY/LIMEIRA, 2015, p. 7)

\section{Quadro 2: Le Petit Prince em cordel}

Além de o texto ser "traduzido" a outro gênero, também as ilustrações de SaintExupéry são "traduzidas" conforme o ambiente de destino: o pequeno príncipe, ainda loiro e com olhos claros, utiliza um típico chapéu de cangaceiro e tem a pele acobreada pelo sol, os pássaros selvagens de Exupéry tornaram-se asas-brancas (bastante afamadas pela canção de Luiz Gonzaga) e a flor de três pétalas encontrada pelo protagonista no deserto foi adaptada a uma flor de mandacaru da caatinga. Por meio de ambientações ao 
regionalismo nordestino, o personagem Vaidoso foi traduzido pelo calunga ${ }^{26}$ do Homem da Meia-Noite, a personagem mais elegante do carnaval pernambucano.

Essa tradução, negada pelos herdeiros de Saint-Exupéry, somente pôde ser publicada em 2015, ano em que as obras do autor passaram a integrar o domínio público. O grau de domesticação presente nessa tradução parece ter incomodado os detentores dos direitos autorais de Exupéry pelo fato de ter ganhado muita autonomia em relação ao texto de origem ${ }^{27}$. No entanto, diferentemente dessa concepção, segundo declaração de Josué Limeira, tradutor da versão em cordel d' O Pequeno Príncipe: “a gente conseguiu trazer Exupéry para o nosso quintal. Foi uma grande responsabilidade transpor isso, mas mantivemos a filosofia e poesia que ele botou no livro" ${ }^{28}$. Nessas palavras, percebe-se, nitidamente, a não exclusão entre a autonomia em domesticar o texto-fonte e, ao mesmo tempo, no julgamento do tradutor, a preservação de elementos importantes da obra de Exupéry.

Além das duas traduções mencionadas, há muitas outras que procederam conforme diversas adaptações linguísticas e culturais, visto que Le Petit Prince já foi traduzido para, pelo menos, 240 línguas $^{29}$, entre as quais idiomas de culturas bem distantes do francês, como o mongol, o albanês, o aramaico, o estoniano, o georgiano, o hindi, o islandês etc.

Questões atinentes à tradução adaptada a características linguístico-culturais do nheengatu também já vieram à baila em alguns momentos da história dessa língua. Vale destacar que Couto de Magalhães, "o mais perfeito conhecedor do nhihingatú no Brasil" segundo o bispo do Amazonas Dom José Lourenço da Costa Aguiar (1898), sofreu críticas que o acusaram de ser um tradutor infiel (FREIRE, 2009, p. 327). No final do século XIX, Couto de Magalhães publicou no jornal Reforma a tradução do auto de

\footnotetext{
${ }^{26}$ Calunga é o boneco conduzido em cortejo de maracatu.

27 Talvez o indeferimento desse projeto tenha se dado, sobretudo, pela modificação das ilustrações de Exupéry, visto que a veiculação dessas ilustrações junto à tradução integral da obra era uma exigência dos membros de sua família.

${ }^{28}$ Esta declaração foi dada por Josué Limeira ao Jornal do Commercio, de Pernambuco, e publicada em 03/10/2015. Para mais informações, cf. http://jconline.ne10.uol.com.br/canal/cultura/literatura/noticia/2015/10/03/o-pequeno-principeganha-versao-em-cordel-201972.php?utm_source=facebook. Acesso em 22/10/2015.

${ }_{29}$ Para mais informações sobre as línguas e sobre os tradutores que participaram desses projetos, cf. http://www.petit-prince.at/collection.htm. Acesso em 28/10/2015.
} 
batismo do neto do imperador D. Pedro II, que, como conhecia o tupi antigo ${ }^{30}$, provavelmente também conseguia entender o nheengatu. Nesse texto foram estabelecidas acomodações linguísticas como as vistas na tradução de "imperador" e "princesa" por muruxáua reté (chefe de fato, chefe a valer; o grande chefe) e "batismo" por cerucaçáua (nomeação) (MAGALHÃES, 1975, $1^{\text {a }}$ parte, pp. 134 e 135). Rebatendo as críticas que recebera de alguns jornais, disse:

Na Nação estranharam que eu não traduzisse litteralmente a expressão -
corpo diplomatico. Effectivamente eu não a traduzi litteralmente, assim como
não traduzi litteralmente as palavras: conselheiros de estado, deputados,
senadores, e servi-me das expressões: homens de governo da nossa patria, e
homens de governo de outras patrias; traduzindo em uma lingua viva, não
me era licito o uso de expressões que nella não são intelligiveis. [...]
Certamente que o verbo cerúca, pelo qual os jesuitas traduziram a palavra
baptisar, e o substantivo cerucaçáua, baptismo, não indicam, entre os
verdadeiros selvagens, a ceremonia christã. Também os mahometanos,
budhistas, os antigos romanos, não tinham o casamento christão, e nem por
isso a palavra casamento é intraductível em árabe, chinez, ou latim.
(MAGALHÃES, 1975, $1^{a}$ parte, p. 137)

Sustentando essa concepção, Couto de Magalhães defende a tarefa de "conservar o sentido fielmente, e traduzi-lo de modo que o selvagem entenda esse pensamento é tudo quanto se deve fazer" (1975, $1^{a}$ parte, p. 140). Na busca por "conservar o sentido" do texto-fonte, Couto de Magalhães procede durante suas traduções mediante adaptações culturais, para obtenção das quais utiliza elementos linguísticos em nheengatu para se fazer entender na cultura de língua nheengatu.

Fazendo proveito da acusação sofrida por Couto de Magalhães, a respeito de sua tradução "infiel", e da sua premissa de "conservar o sentido fielmente", é de extrema valia à condução desta pesquisa e à tradução que proponho do livro Le Petit Prince, ao nheengatu, a discussão sobre o conceito de (in)fidelidade, não somente em relação a assimilações culturais que buscam adequar o texto-fonte à comunidade a que ele se destina, como pôde ser visto nos exemplos desta seção, mas também em relação ao compromisso de fidelidade com a mensagem pretendida pelo autor do texto-fonte. Com relação a esta:

Parece evidente que não se pode exigir uma fidelidade àquilo que é, por definição, inacessível: no caso em pauta, a mensagem pretendida do emissor original. Mesmo a mensagem virtual não é diretamente acessível, mas apenas pela intermediação parcial do processo de decodificação. Assim, a matriz primária da fidelidade há de ser, por imposição dos fatos, a mensagem efetiva

\footnotetext{
30 "Para evitar qualquer duvida no futuro, devo dizer que aqui mesmo no Rio de Janeiro ha diversas pessoas que conhecem a lingua, a saber: Sua Magestade o Imperador que conhece o tupí da costa antigo (...)" (MAGALHÃES, 1975, 1a parte, p. 152).
} 
que o tradutor apreendeu enquanto um entre vários receptores do texto original [...] (AUBERT, 1993, p. 75)

Assim, não há como definir a fidelidade em relação à intenção comunicativa do emissor original e a leituras possíveis da mensagem que ele produziu. O que está submetido ao critério de fidelidade é tão somente a mensagem que se realiza na recepção do texto-fonte. Um mesmo texto pode ser lido por uma mesma pessoa em camadas que desencadeiam mais de uma linha interpretativa, que serão acessadas, entre outros fatores, por meio do conhecimento de mundo de cada leitor e da habilidade de cada um deles em "construir, desconstruir e reconstruir cadeias significativas" (AZENHA, 2006, p. 17). Ademais, a despeito dessas condicionantes individuais, apenas a mudança de lugar ou de época em que o texto de partida é lido, conferir-lhe-á, bem possivelmente, diferentes leituras e interpretações.

Nesse processo, o texto passa de mero depositário de sentidos previamente definidos a ponto de partida para uma rede de associações e dependências efetivadas no ato da leitura e que definem sua singularidade. Suprimida a distância entre um objeto (o texto em si) e um sujeito (seu leitor e tradutor), as relações de sentido se constroem a cada interação e diferentemente. (AZENHA, 2006, p. 19)

Assim, o ato de traduzir está intimamente relacionado ao ato de ler e ao ato de interpretar e é praticado por um sujeito que intervém em um processo de construção de sentido, por meio da interação com o texto-fonte, e de produção de sentido, por meio da elaboração do texto-meta, que, por sua vez, é um novo texto que permitirá novas leituras e interpretações ${ }^{31}$.

Mas o compromisso da fidelidade não se define tão somente na relação texto original/tradutor. Como instrumento humano, suporte, para um ato tradutório, ou seja, de um ato de comunicação interlingual, é de se esperar que o tradutor tenha, como de fato tem - em grau passível, é verdade, de certa variação, conforme a intencionalidade do ato tradutório - um compromisso de fidelidade com as expectativas, necessidades e possibilidades dos receptores finais. $\mathrm{Ou}$, mais apropriadamente, com a imagem que tal tradutor se faz das expectativas, necessidades e possibilidades. (AUBERT, 1993, p. 75)

Esse "compromisso de fidelidade com as expectativas, necessidades e possibilidades dos receptores finais" é firmado, em outras palavras, por meio de um "olhar prospectivo sobre a prática tradutória" que visa à "acomodação do texto traduzido às normas e convenções da cultura receptora" (AZENHA, 2010, pp. 41-42).

\footnotetext{
${ }^{31}$ Essas considerações foram motivadas pela leitura do livro Oficina de Tradução - A teoria na prática, de Rosemary Arrojo.
} 
No entanto, em oposição à noção de acomodação, assimilação ou adaptação, abordada durante esta seção, vale destacar o posicionamento de Antoine Berman em relação ao que chama de "traduções etnocêntricas". Para esse autor, etnocêntrico é: "que traz tudo à sua própria cultura, às suas normas e valores, e considera o que se encontra fora dela - o Estrangeiro - como negativo ou, no máximo, bom para ser anexado, adaptado, para aumentar a riqueza desta cultura" (BERMAN, 2007, p. 28). Berman defende que a tradução etnocêntrica nasce em Roma, no período em que "todo corpus de textos gregos é traduzido", textos que se tornavam irreconhecíveis devido à latinização a que eram submetidos (BERMAN, 2007, p. 30). Além disso, Berman, com a pretensão de associar a cisão platônica entre o "inteligível" e o "sensível" à tradução etnocêntrica, considera que essa separação ratifica a captação de sentido como "traslação", ou seja, como uma mudança de uma língua à outra, acarretando, nesse percurso, a perda de sua matéria.

\begin{abstract}
Partir do pressuposto que a tradução é a captação do sentido, é separá-lo de sua letra, de seu corpo mortal, de sua casca terrestre. É optar pelo universal e deixar o particular. A fidelidade ao sentido opõe-se - como para o crente e o filósofo - à fidelidade à letra. Sim, a fidelidade ao sentido é obrigatoriamente uma infidelidade à letra. (BERMAN, 2007, p. 32)
\end{abstract}

Ademais, "a transmissão do sentido é má porque o sentido está ligado à letra, e a captação do sentido só nos proporciona uma mensagem confusa, deformada [...]" (BERMAN, 2007, p. 43). Evidentemente, não há como manter o mesmo corpo com a mudança de códigos, assim como não é possível mantê-lo dentro de uma mesma língua quando nela procuramos sinônimos. Se se levar à risca esses conceitos, temos de dizer que todas as traduções são infiéis e etnocêntricas, sem exceção. Seria possível traduzir algo e ao mesmo tempo não perder nada? Seria possível traduzir algo de uma língua sem ao menos tentar atinar para o seu sentido e como se dará a tradução desse sentido a outra língua? Se se tomarem como negativas as respostas a essas questões, entende-se a afirmação de Berman: "a captação do sentido afirma sempre a primazia de uma língua" (BERMAN, 2007, p. 33); como: toda tradução afirma a primazia da língua para a qual se traduz. E isso fica patente em:

Para que haja anexação, o sentido da obra estrangeira deve submeter-se à língua dita de chegada. Pois a captação não libera o sentido numa linguagem mais absoluta, mais ideal ou mais "racional": ela o encerra simplesmente numa outra língua, considerada, é verdade, como mais absoluta, mais ideal e mais racional. E esta é a essência da tradução etnocêntrica; fundada sobre a primazia do sentido, ela considera implicitamente ou não sua língua como um 
ser intocável e superior, que o ato de traduzir não poderia perturbar. Trata-se de introduzir o sentido estrangeiro de tal maneira que seja aclimatado, que a obra estrangeira apareça como um "fruto" da língua própria. (BERMAN, 2007, p. 33)

Parece difícil pensar em uma tradução que não aclimate o texto-fonte, visto que o processo tradutório é um processo complexo relacionado a mudanças de participantes, códigos, referentes, espaços, épocas, canais. Assim, até que ponto uma mudança não seria considerada uma captação, anexação, adaptação, acomodação, assimilação ou aclimatação?

Seguindo seu raciocínio, Berman pontua que "cada cultura deve saber se apropriar das produções de sentido estrangeiras. Mas isso não concerne às 'obras'. Evidentemente, as 'obras' fazem sentido e querem a transmissão de seu sentido" (2007, p. 38). Diante dessa concepção, a leitura que se faz da obra - e, por meio dela, a construção de sentido - perde destaque às obras, que por si só, teleologicamente, “querem a transmissão de seu sentido".

Berman fala ainda em um "contrato fundamental que une uma tradução a seu original. Esse contrato - seguramente draconiano - proíbe ir além da textura do original" (2007, pp. 38-39, grifo do autor). Sobre isso, permanecem, ao menos, duas dúvidas: esse contrato é assinado por quem? Tal lei foi/é estipulada por quem?

Em relação ao que chama de "tradução literal” (2007, p. 35), já é difícil imaginar entre línguas próximas, da mesma família, um projeto de tradução que se proponha e que se faça literal. O que dizer, então, entre línguas que são tipológica e culturalmente distantes, como uma indo-europeia (por exemplo: o francês) e uma não indo-europeia (por exemplo: o nheengatu)?

É válido ressaltar, contudo, que Berman situa suas considerações em um contexto muito diferente daquele no qual minha proposta de tradução se insere. Ele reivindica o alargamento das possibilidades linguísticas da língua francesa (língua já consagrada, com vastíssima tradição literária) por meio de traduções que não se acomodem às características linguístico-culturais francesas, mas que, atentas às diferenças encontradas na língua-fonte, possam reproduzi-las na língua-meta, contribuindo, dessa forma, para o aumento do repertório discursivo da cultura de língua francesa. Ainda que adequadas a essa situação, as considerações de Berman são questionáveis, visto que há uma incompatibilidade entre o que se propõe e o que, de fato, é possível se realizar na prática. Autores que discordaram de Berman, curiosos em 
testar ou analisar traduções de acordo com as suas considerações categóricas, verificaram que o próprio Berman ao traduzir não conseguia respeitá-las. Há um interessante texto intitulado Berman, étranger à lui-même?, de Marc Charron (2001), que se propõe a demonstrar que o tradutor Berman não consegue se libertar das tendências deformadoras da tradução que o teórico Berman tanto condenou.

Em uma abordagem mais amena e mais elucidativa, Haroldo de Campos, no texto Da tradução como criação e como crítica (1992), formula a sua argumentação em que entende a tradução como um processo de recriação do material verbal. Partindo da apresentação do ponto de vista do ensaísta Albercht Fabri, do filósofo e crítico Max Bense e de Sartre, que defendem, para alguns textos (sobretudo na poesia, embora em prosa isso também seja possível ${ }^{32}$ ), a palavra como matéria, como palavra-coisa, e a sua intraduzibilidade devido à impossibilidade de substituição de sua expressividade, Campos sustenta o seu posicionamento:

Admitida a tese da impossibilidade em princípio da tradução de textos criativos, parece-nos que esta engendra o corolário da possibilidade, também em princípio, da recriação desses textos. Teremos, como quer Bense, em outra língua, uma outra informação estética, autônoma, mas ambas estarão ligadas entre si por uma relação de isomorfia: serão diferentes enquanto linguagem, mas, como os corpos isomorfos, cristalizar-se-ão dentro de um mesmo sistema. (CAMPOS, 1992, p. 34)

Assim, Haroldo de Campos, como ele mesmo considera, situa-se em uma posição contrária à tradução literal quando propõe um modo de traduzir que dê conta da materialidade das palavras (propriedades sonoras, imagética visual), no qual a semântica funciona como uma "baliza demarcatória da empresa recriadora" (CAMPOS, 1992, p. 35). Em outras palavras, o conteúdo serve de auxílio à recriação estética da forma, assim, nesse processo, esta ganha primazia sobre aquele. Além disso, mais do que o sentido de cada palavra, traduz-se o efeito de sentido interpretado durante a leitura do original, recriado no processo de tradução. Diferentemente de Berman, percebe-se aqui a "mão do tradutor", ciente de uma escolha que lhe acarretará perdas, em um trabalho cujo resultado não poderá ser chamado de "texto infiel", visto que recria fielmente o texto de partida, dentro das possiblidades e limitações da língua para qual se traduz. Se se considerar o signo saussureano, no caso das traduções dos textos chamados

\footnotetext{
${ }^{32}$ Campos cita James Joyce e Guimarães Rosa como autores que utilizam em prosa recursos expressivos encontrados com mais frequência em poesia.
} 
"criativos", a abordagem de Haroldo de Campos, perante os graus de dificuldade impostos pelos textos, prefere corromper o significado ao significante.

Diante de diferentes perspectivas e das dificuldades que se impõem, constitutivas do processo tradutório, caracterizado pelo compromisso instável entre certo grau de diversidade e certo grau de identidade ${ }^{33}$, segundo as já citadas palavras de Francis Aubert, proponho aqui uma reflexão ancorada na concepção de que as traduções constituem um trabalho criativo, por meio do qual um novo texto é criado, em alguns momentos mais próximo e em outros mais distante do texto de partida, gerenciado pelo tradutor - sujeito intermediador entre culturas - e realizado por uma ação necessariamente dinâmica e modificadora.

33 Em outras palavras, Paulo Henriques Britto fala em um pêndulo em que autonomização e aproximação ora afastam ora aproximam o texto traduzido do texto original (BRITTO, 1999, p. 245). 


\section{Algumas fontes para o conhecimento do nheengatu}

Nesta seção serão apresentados de modo contextualizado alguns trabalhos concernentes à língua nheengatu e à sua história, sobretudo aqueles que foram ou são considerados materiais importantes para o seu conhecimento. Ademais, todas as obras mencionadas a seguir foram utilizadas como fonte de pesquisa lexical e sintática ao longo da tradução de Le Petit Prince ao nheengatu.

\subsection{O Selvagem (1876), do general Couto de Magalhães}

O general José Vieira Couto de Magalhães (1837-1898) foi presidente de várias províncias do Brasil: Goiás (1862-3), Pará (1864-5), Mato Grosso (1866-8) e São Paulo (1888) (FREIRE, 2011, p. 144). Durante as várias viagens que fez pelos rincões do Brasil, pôde aprender muito bem o nheengatu, tendo sido considerado por muitos, entre os quais o já citado bispo do Amazonas Dom José Lourenço da Costa Aguiar, "o mais perfeito conhecedor do nhihingatú no Brasil" (1898). Na verdade, tal denominação dada à língua anteriormente conhecida como "língua geral amazônica" foi adotada ${ }^{34}$ em $O$ Selvagem e, devido à sua repercussão, passou a se vulgarizar. Tanto é verdade que essa obra conta com três edições em português - 1876, 1913, 1975 - e foi traduzida e editada em várias línguas, como francês, inglês, alemão e italiano (FREIRE, 2011, p. 144). No entanto, como bem nos esclarece o filólogo Frederico Edelweiss, tal termo já havia sido empregado por Manuel Justiniano de Seixas ${ }^{35}$ em seu Vocabulário da Língua Indígena Geral para Uso do Seminário Episcopal do Paráa ${ }^{36}$, de 1853 (EDELWEISS, 1969, p. 200). Este, então, seria o registro mais antigo do termo nheengatu para designar a língua geral moderna do Amazonas. Contudo, foi Couto de Magalhães o primeiro a utilizar

\footnotetext{
34 "Se dissermos a qualquer indio civilisado do Amazonas: falle em lingua tupi - elle não entende o que Ihe queremos dizer; para que elle entenda que queremos que elle se expresse na sua propria lingua, mister é dizer-lhe: Renhehen nhehengatú rupí, litt.: falle lingua boa pela, isto é: falle pela lingua boa. Estes factos fizeram-me adoptar os vocabulos ava nhehen e nhehengatú para exprimir, o primeiro, a lingua guarani; o segundo, a lingua tupi." (MAGALHÃES, 1975, 1a parte, p. XXXVIII-XXXIX)

35 Manuel Justiniano de Seixas foi o regente da Cadeira de Língua Indígena Geral, em 1851, no seminário do Pará (EDELWEISS, 1969, p. 189).

${ }^{36}$ Segundo Edelweiss (1969, p.189), esta "foi a primeira publicação da terceira etapa na trajetória do tupi, a fase nheengatu".
} 
sistematicamente tal denominação, associando-a, à época, ao entendimento da língua tupi viva, assim como aparece em algumas seções de $O$ Selvagem: "Nhehengatú ou tupí vivo" e "Curso de lingua tupí viva ou nhehengatú".

O Selvagem, publicação mais importante do general Couto de Magalhães, insere-se em um contexto em que o controle de terras e o desenvolvimento econômico do país eram temas de extrema preocupação. Motivado por um grande ímpeto nacionalista e embalado pelo pensamento progressista, influenciado à época pela corrente ideológica do Positivismo ${ }^{37}$, Couto de Magalhães expõe algumas razões à publicação de sua obra, justificando a setores da administração imperial a importância de os militares aprenderem o nheengatu a fim de domesticar/amansar os selvagens processo que consistia em fazê-los entender o português para incorporá-los à civilização. Com esse intuito, ambiciona em seu livro contribuir para a formação de um corpo de militares-intérpretes proficientes em nheengatu para que, por meio desta língua, eles pudessem ensinar aos selvagens a língua portuguesa.

Tendo como pano de fundo esta evidente motivação econômica:

Domesticar os selvagens ou fazer com que elles nos entendam, o que é a mesma cousa, equivale a fazermos a conquista pacifica de um territorio quase do tamanho da Europa, e mais rico que ella.

Só essa conquista vale milhões; feita ella, porém, não conseguiriamos somente a posse real da maior parte do territorio do imperio; conseguiriamos tambem um milhão de braços aclimados, e os unicos que se prestam ás industrias, que por muitos annos serão as unicas possiveis no interior - as extractivas e pastoris. (MAGALHÃES, 1975, $1^{a}$ parte, p. VIII)

e aludindo ao sucesso da colonização portuguesa, na qual os intérpretes tiveram papel fundamental, Couto de Magalhães, com este estudo encomendado pelo governo imperial do Brasil (como ele mesmo faz questão de ressaltar algumas vezes) ${ }^{38}$, justifica a relevância prática de seu trabalho, cuja parte principal é o "Curso de Língua Geral pelo methodo de Ollendorf". Tal método, o qual "os modernos philologos europeus han inventado para vulgarisação das linguas vivas" (1975, $1^{\text {a }}$ parte, p. VII), se vale de diálogos nos quais o léxico e as regras gramaticais são apresentados por meio de exercícios de perguntas e respostas, no caso em questão, ora em português ora em nheengatu. Apresenta, portanto, uma relevância prática que ele adverte a seus leitores

\footnotetext{
${ }^{37}$ Influência que notamos nos dizeres da bandeira nacional brasileira: Ordem e Progresso.

${ }^{38} \mathrm{O}$ Selvagem, que contém uma dedicatória em nheengatu a Dom Pedro II, foi impresso pelo governo imperial para figurar na Exposição Universal da Filadélfia, na qual também seriam apresentados outros trabalhos referentes ao "homem americano" feitos por estudiosos de países da América do Sul, Central e do Norte (MAGALHÃES, 1975, 1a parte, pp. XVIII).
} 
que não se restringe ao estudo da língua geral apenas pelos militares, mas também a todos os civis em contato com o "selvagem”, a fim de assimilá-lo à civilização.

\begin{abstract}
Eu peço especialmente aos habitantes das immensas provincias do Pará e Amazonas, negociantes, seringueiros, donos de barcos, fabricantes de pirarucú, salça, oleo de copahyba, cravo, e em geral a todos quantos dependam do braço do selvagem que, nas horas vagas, leiam ou mandem lêr á este a parte do curso, que vai da pag. 14 até o fim das lendas, lendo primeiro o tupi, e depois o portuguez correspondente, nome por nome, oração por oração, e ficarão sorprehendidos da rapidez com que o selvagem aprenderá nossa lingua.

Aqueles que tomarem em consideração esta lembrança, consultarão a seus legitimos interesses, porque o selvagem que falla o portuguez, vale, pelo menos, tanto como dous boçaes; assim, cada cidadão desses se converterá em um catechista, attendendo aos interesses de seu commercio ou industria. $\mathrm{O}$ commercio e a industria foram, em todos os tempos, os primeiros auxiliares da fé e da civilização. (MAGALHÃES, 1975, $1^{\text {a }}$ parte, p. XLIV)
\end{abstract}

Esse esforço de assimilação das populações indígenas ao ideário da civilização cristã coaduna-se ao que já se observava em países da América do Sul, Central e do Norte.

A importância do índio, na visão de Couto de Magalhães, associa-se, ademais, à necessidade de povoação das terras intertropicais, as quais eram inóspitas aos brancos. Sobre a mão de obra indígena nas terras em que a civilização ainda não se fazia presente, que representavam quase dois terços do território do império, afirma que "tornar productiva uma população, hoje improductiva, é, pelo menos, tão importante como trazer novos braços" (MAGALHÃES, 1975, $1^{\text {a }}$ parte, p. XXI). No entanto o índio, para Couto de Magalhães, é visto como o principal instrumento de riqueza do país devido às atividades extrativistas que só ele pode/consegue desempenhar.

Em linhas gerais, vê-se até então uma concepção utilitarista em relação ao índio, sobre o qual recaem as ambições da elite administrativa, que almeja inseri-lo na civilização a fim de que ele deixe de ser um obstáculo ao povoamento do interior do Brasil e possa servir como mão de obra especializada em atividades cuja riqueza gerada alimentaria um projeto de nação, no qual o próprio índio não tem voz. Ou seja, o "selvagem" é concebido como uma propriedade da nação e encaixotado em um projeto desenvolvimentista que não faz o menor sentido a ele.

O facto da existencia desse milhão de braços, ocupando e dominando a maior parte do territorio do Brazil, podendo irromper para qualquer lado contra as populações christãs, é um embaraço para os progressos do povoamento do interior, e é um perigo que crescerá na proporção em que elles forem ficando mais apertados: a questão pois não versa só sobre a utilidade que podemos tirar do selvagem; versa também sobre os perigos e despesas que faremos, se 
não cuidarmos agora de amansal-os. (MAGALHÃES, 1975, $1^{\text {a }}$ parte, p. XXVII)

Ainda que pareça estranho a esse propósito, o desejo de uma condução pacífica nesse processo é reiterado repetidas vezes pelo autor de $O$ Selvagem. Tal preocupação não se relaciona apenas ao risco de perda de vidas humanas - ou à perda dos "braços aclimados" -, mas também (ou sobretudo) ao gasto financeiro caso um embate violento se desse entre o exército e os "selvagens" 39 .

Couto de Magalhães defende seu projeto de amansamento do "selvagem" afirmando que com ele o governo despenderia menos gastos do que se tivesse de remediar uma situação em que tropas do exército teriam de conter a revolta de enormes grupos indígenas, o que ocasionaria prejuízos sociais devido a conflitos sanguinolentos que se travariam no interior. Para que o derramamento de sangue não ocorresse, as atenções deveriam estar voltadas à criação de um corpo de intérpretes, que seria composto em sua maior parte por integrantes do exército.

Esta só consideração basta para tornar patente o empenho com que devemos nos prover de interpretes para actuar entre esses barbaros, e impedir que eles continuem a ser, como disse, um obstaculo para o povoamento de tão vasta porção do imperio, quando tão uteis lhe podem ser desde que nos deliberemos a empregar os meios para utilisal-os. (MAGALHÃES, 1975, $1^{\text {a }}$ parte, pp. XLI, XLII)

Ademais, corroborando com ideias semelhantes aos dos antigos colonos portugueses, com destaque às atividades desenvolvidas pelos jesuítas e seu corpo de línguas $^{40}$, Couto de Magalhães alude a uma suposta motivação humanitária, a qual contempla o julgamento de superioridade espiritual do homem branco cristão em relação ao índio em estágio "primitivo", "bárbaro":

Além dos fins economicos e administrativos que se ligão ao assumpto, e que
ficaram ligeiramente esboçados, há um fim humanitario a attender-se e que
não pode ser indefferente a nem um povo civilisado, por quanto:
Promover isto: seria tambem promover a realização daquelle sublime
mandato que Christo confiou a todo povo christão diante de um povo
barbaro, nas seguintes sublimes palavras do Evangelho:
Ite ad eos qui in tenebris et umbris mortis sedant, ad dirigendum pedes eorum
in viam pacis.

${ }^{39}$ A questão financeira parece mesmo ser o que mais preocupa Couto de Magalhães. A fim de sustentar o seu argumento, cita como exemplo o que ocorreu na Argentina no ano de publicação de seu livro, 1876: “Em Janeiro d'este anno ainda os jornaes deram noticia dos estragos que elles fizeram na Republica Argentina, estragos que montaram, além da perda de vidas, em mais de mil e quatrocentos contos de nossa moeda!" (MAGALHÃES, 1876, 1a parte, p. XXVIII).

${ }^{40}$ Nome pelo qual eram conhecidos os missionários-intérpretes. 
"Ide á aqueles que jazem sentados nas sombras e trevas da morte, e dirigi seus passos pela estrada da paz." (MAGALHÃES, 1975, $1^{\text {a }}$ parte, p. XLII)

É importante contextualizar que Couto de Magalhães apresenta as justificativas e os meios necessários para o empreendimento de seu trabalho a uma comissão incumbida de avaliar a pertinência de suas considerações a fim de que seu projeto fosse aceito e divulgado entre a classe pensante nacional ${ }^{41}$. Em linhas gerais o autor, que era um militar, faz a propaganda de seu estudo a fim de obter a aprovação de uma comissão específica a serviço do império, a saber: Comissão Superior da Quarta Exposição Nacional.

Por mais que transpareça ao leitor que a sua atenção esteja centrada apenas em interesses econômico-administrativos que beneficiariam o progresso da nação, o autor de $O$ Selvagem enaltece, por meio de comentários elogiosos, a beleza da língua que pretende ensinar, o nheengatu. Além disso, destaca de modo geral a importância de que novas línguas, muitas das quais desconhecidas, sejam estudadas.

\footnotetext{
Cada nova lingua que se estuda, é mais importante para o progresso da humanidade do que a descoberta de um genero novo de mineraes ou de plantas.

Cada lingua que se extingue, sem deixar vestigios escriptos, é uma importante pagina da historia da humanidade que se apaga, e que depois não poderá mais ser restaurada. (MAGALHÃES, 1975, 1ª parte, p. XXXIX)
}

Talvez seja esta mesmo a maior contribuição de Couto de Magalhães: ter deixado um importante registro escrito em nheengatu, importante não só pela qualidade do curso que elaborou, mas também para o conhecimento das lendas em nheengatu que coletou e traduziu ${ }^{42}$.

O general Couto de Magalhães em várias passagens também enaltece a qualidade literária das lendas coligidas por ele, comparando algumas delas à beleza das lendas de La Fontaine (MAGALHÃES, 1975, $1^{\text {a }}$ parte, p. 157).

Tais lendas trouxeram, sobretudo, a personagem jabuti como protagonista em tramas consideradas pioneiras ao público letrado daquela época. Essas narrativas

\footnotetext{
${ }^{41}$ Antes de começar a introdução de seu trabalho, Couto de Magalhães diz: "Memoria apresentada a Comissão Superior da Quarta Exposição Nacional, onde são estudados e discutidos os diversos problemas economico-sociais, que dependem do amansamento do selvagem do Brazil, e em que se pede á Comissão, em nome de interesses futuros muito preponderantes do imperio, que tome a si o recommendar o assumpto á attenção das classes pensantes de nossa patria." (MAGALHÃES, 1975, 1ạ parte, p. XVII)

${ }^{42}$ As narrativas em nheengatu de $O$ Selvagem são acompanhadas de sua tradução interlinear ao português.
} 
serviram de inspiração a muitos escritores brasileiros, principalmente aos da segunda fase do Modernismo paulista, no momento em que elaboravam o Movimento Antropofágico (SÁ, 2012, pp. 203-204). Mário de Andrade, para a composição de Macunaíma (1928), certamente, foi um dos que mais bebeu dessa fonte ${ }^{43}$. Nessa época, período em que se buscava uma teoria de identidade nacional, Oswald de Andrade, autor do Manifesto Antropófago (1928), alude à figura do jabuti como símbolo de resistência cultural às influências colonialistas que perduravam na elite intelectual brasileira - "somos fortes e vingativos como o Jabuti"44 (ANDRADE, 1972, p.17).

Após combater dura e sarcasticamente essa elite, que copiava modelos artísticos europeus, o processo de catequização dos índios e o romance indianista $O$ Guarani, de José de Alencar (bem como sua ópera homônima, composta por Carlos Gomes), em que o herói indígena Peri é retratado "cheio de bons sentimentos portugueses", Oswald diz:

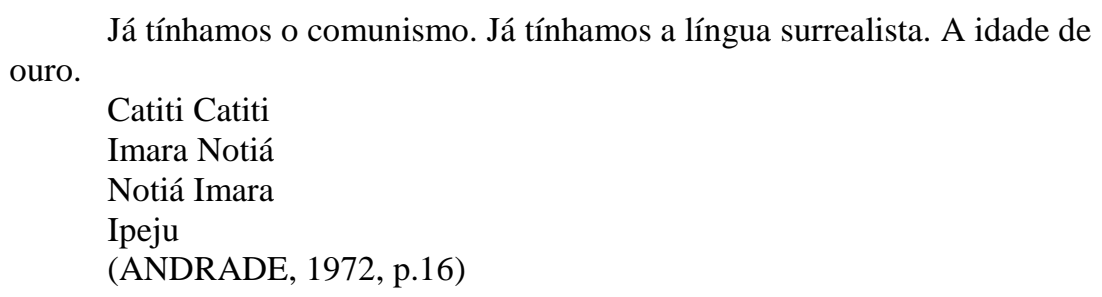

Os versos aludidos acima originalmente compõem uma canção coletada por Couto de Magalhães ${ }^{45}$, presente em O Selvagem (MAGALHÃES, 1975, $2^{\text {a }}$ parte, p. 142). Catiti, segundo Couto, era o nome atribuído à lua nova, que era apenas um entre os vários deuses tupis. Tanto a lua nova - Catiti - como a lua cheia - Cairé - eram entes que tinham a "missão de despertar saudades no amante ausente" (MAGALHÃES, 1975, $2^{\mathrm{a}}$ parte, p. 139).

Como disse acima, as luas cheia e nova, que eram segundo os Tupis, cousas distinctas, e seres diversos, constituiam auxiliares de Rudá, e tinham

\footnotetext{
${ }^{43}$ Não somente de O Selvagem, mas também da Poranduba Amazonense e das Lendas em Nheengatu e em Português, textos que serão apresentados mais adiante.

${ }^{44}$ Lembrando que, de acordo com Couto de Magalhães, o jabuti é um dos animais mais fracos da fauna brasileira, mas que consegue obter êxito sobre quadrúpedes bem mais fortes do que ele por meio de sua astúcia e inteligência (MAGALHÃES, 1975, 1a parte, p. 149).

45 Os versos citados por Oswald não foram traduzidos por Couto de Magalhães pelo fato de este não atinar ao significado de algumas palavras que os compõem, o que foi justificado assim: "ou a lingua está adulterada, ou é algum fragmento de tupí anterior ás transformações porque já tinha passado a lingua, quando nos foi conhecida, porque palavras ha que não entendo" (MAGALHÃES, 1975, 2a parte, p. 140). Isso provavelmente corrobora a escolha de Oswald em relação a versos em que o apelo sonoro e a expressividade característica da oralidade parecem ser mais importantes que o significado que possuem. A valorização da oralidade, sobretudo dos usos não abonados pelas gramáticas e pela literatura considerada canônica, ganhou muita importância no Movimento Modernista.
} 
invocações semelhantes ás que se cantavam áquelle deus, e para o mesmo fim de trazer os amantes ao lar domestico pelo poder da saudade. (MAGALHÃES, 1975, 2a parte, p. 141)

Rudá $^{46}$, o deus mencionado acima, é descrito por Couto de Magalhães como deus do amor ou da reprodução (MAGALHÃES, 1975, $2^{\text {a }}$ parte p. 136). Assim como esse deus, Guaracy (o sol) e Jacy (a lua) também eram considerados deuses superiores, aos quais outros deuses estavam submetidos. Guaracy é o deus responsável pela criação dos homens e de todos os seres vivos animais; Jacy, por sua vez, é a entidade responsável pelos seres vegetais. A ambos os deuses estão associados alguns seres sobrenaturais, entre os quais estão Anhanga, Caipora, Boi-tatá e Curupira (MAGALHÃES, 1975, $2^{\mathrm{a}}$ parte, pp. 136-139).

Ainda em relação à pluralidade dos deuses tupis, a importância de $O$ Selvagem já havia sido percebida antes da elaboração dos pilares do antropofagismo. Machado de Assis, em uma nota referente ao poema "Potira", de seu livro de poesias intitulado Americanas $(1875)^{47}$, diz:

Tinham os índios a religião monoteísta que a tradição lhes atribui? Nega-o positivamente o Sr. Dr. Couto de Magalhães em seu excelente estudo acerca dos selvagens, asseverando nunca ter encontrado a palavra Tupã nas tribos que freqüentou, e ser inadmissível a idéia de tal deus, no estado rudimentário dos nossos aborígenes.

O Sr. Dr. Magalhães restituiu aos selvagens a teogonia verdadeira. Não integralmente, mas só em relação ao sol e à lua (Coaraci e Jaci), acho notícia dela no Tesouro do padre João Daniel; e o que então faziam os índios, quando aparecia a lua nova, me serviu à composição que vai incluída neste livro.

Sem embargo das razões alegadas pelo Sr. Dr. Magalhães, que todas são de incontestável procedência, conservei Tupã nos versos que ora dou a lume; filo por ir com as tradições literárias que achei, tradições que nada valem no terreno da investigação científica, mas que têm por si o serem aceitas e haverem adquirido um como direito de cidade. (ASSIS, s/ data, p. 66) (8 $^{48}$

Essas informações referentes aos deuses tupis, bem como muitas outras de naturezas diversas ${ }^{49}$, compõem uma parte de $O$ Selvagem em que seu autor se debruça

\footnotetext{
${ }^{46}$ A título de curiosidade, tenha influência ou não, Rudá é o nome do segundo filho de Oswald de Andrade, fruto de sua união com a também escritora Patrícia Galvão, a Pagu.

${ }^{47}$ Ainda que a publicação do referido livro de Machado de Assis tenha ocorrido um ano antes de $O$ Selvagem, sabe-se que a segunda parte deste livro foi apresentada por seu autor ao Instituto Histórico e Geográfico Brasileiro em 1874 (SÁ, 2012, p. 162).

48

Texto

disponível

em:

http://www.dominiopublico.gov.br/pesquisa/DetalheObraForm.do?select_action=\&co_obra=2062.

Acesso em 10/01/2017.

${ }^{49} \mathrm{O}$ trabalho de Couto de Magalhães, além de um curso prático ao ensino do nheengatu, "é um trabalho antropológico que contempla aspectos culturais, econômicos, geográficos, linguísticos e mitológicos de povos indígenas brasileiros" (ALTMAN, 2012, p. 27).
} 
em um extenso estudo etnográfico acerca de diferentes etnias em solo brasileiro. Ainda que Couto de Magalhães reiterasse várias vezes que seu trabalho não tinha rigor nem pretensões científicas, $O$ Selvagem "causou impacto nos campos então incipientes da antropologia, etnologia e linguística brasileiras" (ALTMAN, 2012, p. 28), e seu autor passou a ser considerado por muitos o iniciador dos estudos folclóricos no Brasil.

\subsection{Poranduba Amazonense (1890), de João Barbosa Rodrigues}

João Barbosa Rodrigues (1842 - 1909), natural de Minas Gerais, foi um botânico que viveu no Amazonas em dois momentos diferentes (1872-1874 e 18831890) (FREIRE, 2011, p. 104). Dirigiu o Museu Botânico da cidade de Manaus durante sete anos e, ademais dessa atividade, interessou-se pelo estudo do nheengatu e coletou nessa língua uma série de narrativas orais ${ }^{50}$ - lendas mitológicas, contos zoológicos, contos astronômicos e botânicos, cantigas - de diferentes regiões amazônicas, muitas das quais foram reunidas em sua publicação mais conhecida: Poranduba Amazonense ${ }^{51}$.

Apesar da riqueza cultural desse farto material em nheengatu (334 páginas), o filólogo Edelweiss não poupou críticas severas aos estudos de Barbosa Rodrigues, chegando a classificar seu autor como "uma das maiores negações no campo linguístico" (EDELWEISS, 1969, p. 202). Críticas essas que apontam para contradições no discurso do eminente botânico, como a que segue abaixo:

\footnotetext{
Quando emprego a palavra abanheenga, cumpre-me advertir, quero com isso dizer a língua do índio, a matriz anterior à escrita por Anchieta e Montoya, conservando a de nheengatu para o tupi do Amazonas; a de guarani para a do Paraguai. (RODRIGUES apud EDELWEISS, 1969, p. 202)

Aquela nação (dos tupi-guaranis) falava uma só língua: o abanheenga ou nheengatu. (RODRIGUES apud EDELWEISS, 1969, p. 203)
}

Ainda que tal crítica seja de fato muito dura, embora procedente e fundamentada, havia à época, entre muitos estudiosos, uma grande dificuldade em estabelecer distinções entre uma língua e dialetos de uma mesma língua. Muitos estudiosos do nheengatu e do guarani, no século XVIII, partilharam da ideia de uma

\footnotetext{
50 Tais narrativas vêm acompanhas de tradução interlinear ao português e são seguidas de suas respectivas traduções livres.

51 Barbosa Rodrigues, entre outras considerações de ordem etimológica, apresenta o seguinte significado para poranduba : "historias phantasticas, fabulas, abusões" (RODRIGUES, 1890, p. II).
} 
grande unidade linguística (ainda que considerassem a existência de pequenas variantes dialetais) falada em um vastíssimo território, dada a possibilidade de seus falantes estabelecerem níveis satisfatórios de comunicação entre si (FREIRE, 2011, p. 102-103).

A despeito de críticas acerca de suas controversas reflexões linguísticas, Barbosa Rodrigues, em Poranduba Amazonense, contribuiu significativamente para a divulgação do repertório cultural contido nas narrativas em nheengatu que coligiu e traduziu. Das narrativas que compilou, Barbosa Rodrigues identifica-as de acordo com os rios em que as ouviu. Uma delas, colhida no rio Tapajós, intitulada Yurupari camunduçara irumo $(\mathrm{O}$ Jurupari e o caçador), apresenta a seguinte tradução livre ao português ${ }^{52}$ :

Um homem foi caçar e encontrou uma veada com filho. Frechou o filho, e pegou no veadinho. A mãe fugiu. Fez chorar o veadinho e a mãe quando ouviu veio. Frechou, então, também a mãe do veadinho. Morreu. Olhando para ella viu que a veada era sua propria mãe.

O Yurupari transformou a mãe em veada para enganar o filho emquanto dormia. (RODRIGUES, 1890, p. 135)

Essa lenda foi musicada em nheengatu, sem nenhuma alteração em relação ao registro de Barbosa Rodrigues, pelo compositor Heitor Villa-Lobos. Além disso, este é um entre vários enredos de narrativas indígenas que serviram de inspiração a Mário de Andrade na composição de Macunaíma, como se vê abaixo:

- Essa eu caço! ele fez. E perseguiu a viada. Esta escapuliu fácil mas o herói pôde pegar o filhinho dela que nem não andava quase, se escondeu por detrás duma carapanaúba e cotucando o viadinho fez ele berrar. A viada ficou feito louca, esbugalhou os olhos parou turtuveou e veio vindo veio vindo parou ali mesmo defronte chorando de amor. Então o herói flechou a viada parida. Ela caiu esperneou um bocado e ficou rija estirada no chão. O herói cantou vitória. Chegou perto da viada olhou que mais olhou e deu um grito, desmaiando. Tinha sido uma peça do Anhanga... Não era viada não, era mas a própria mãe tapanhumas que Macunaíma flechara e estava morta ali, toda arranhada com os espinhos das titaras e mandacarus do mato. (ANDRADE, 2012, p. 23)

Na versão de Mário de Andrade, Macunaíma ocupa o papel do caçador, e Anhanga, de Jurupari. Jurupari e Anhanga ${ }^{53}$ são entidades que habitam a mata e muitas vezes são confundidos ${ }^{54}$, como neste caso em que uns contam ser o feito uma obra do Jurupari, e outros o atribuem a Anhanga. Como Mário de Andrade bebeu de várias fontes, estabelecendo em seu texto uma miscelânea intertextual de narrativas indígenas

\footnotetext{
52 Tradução feita pelo próprio João Barbosa Rodrigues.

53 Esses dois termos foram utilizados pelos missionários no contexto de catequese para traduzir o conceito de Diabo presente na doutrina cristã.

${ }^{54}$ Barbosa Rodrigues esclarece: "no Norte é Yurupari, no Sul Anhanga" (RODRIGUES, 1890, p. 93).
} 
de diferentes regiões, as alterações dos enredos originais e a criação ficcional em Macunaíma fazem dessa obra uma "cópia modificada" de diversas tradições orais.

A respeito do interesse de se conhecer narrativas indígenas de tradições orais, o objetivo de Barbosa Rodrigues nesse âmbito consistia em, além da ambição de folclorista de fazer com que elas não desaparecessem ao longo do tempo a fim de mostrar o "estado intellectual da raça", registrar o estágio da língua àquela época para que se notasse a modificação pela qual vinha passando desde os escritos dos missionários no século XVI (RODRIGUES, 1890, p. II).

\subsection{Elementos necessários para aprender o nheengatú (1909), de Dom Frederico Costa}

Dom Frederico Benício de Sousa Costa (1875 - 1948) foi o segundo bispo do Amazonas, "natural da Vila de Boim, às margens dos Rios Tapajós, Frederico Costa foi o primeiro prelado de Santarém, ocupando o cargo entre 1904 e 1906, ano em que foi nomeado Bispo do Amazonas" (FONSECA apud ÁVILA, 2016, p. 53). O estudo que ora se apresenta está contido em uma publicação maior, intitulada Carta pastoral de D. Frederico Costa, bispo do Amazonas, a seus amados diocesanos (1909). Nele, além de uma pequena lição gramatical da língua nheengatu, há uma série de relatos de viagens (uma espécie de diário) por rios amazônicos, traduções de orações católicas e um vocabulário em nheengatu/português e em português/nheengatu.

Essa obra está centrada na variante da língua falada no Rio Negro, lugar em que seu autor ouviu e aprendeu o nheengatu. Tal publicação veio à tona, como disse Dom Frederico Costa, devido a pedidos de algumas pessoas e a fim de atender a uma ambição específica: auxiliar no processo de catequização dos índios.

\footnotetext{
Não ousaria jamais publical-o si não fossem os numerosos pedidos que me fizeram no correr da minha viagem, e, sobretudo, o desejo de auxiliar os sacerdotes que tiverem de exercer o ministerio nesta parte importantissima do Amazonas. Sem o conhecimento do Nheengatú, infructiferos serão os esforços para catechizar os indios. (COSTA, 1909, p. 155)
}

Sobre a necessidade de se aprender o nheengatu, o então bispo do Amazonas relata um episódio acontecido no dia 5 de julho de 1908 após a chegada do barco em que estava à cidade de Santa Izabel do Rio Negro. 
Pela primeira vez sentimo-nos como que exilado dentro da nossa propria patria; parecia-nos estar em outras terras, entre povos extranhos. Ouviamos falar ao redor e não entendiamos. Debalde o Snr. Netto, com sua agradavel palestra, procurou distrahir-nos, nosso espirito estava demasiadamente preoccupado. E nossa preoccupação d'então era aprender a lingua geral sem a qual, bem o percebemos immediatamente, inutil, infructifera, baldada seria a nossa viagem. Procuramos, pois, desde esse momento pôr-nos em contacto direto e immediato com o pessoal indigena que nos rodeava muito admirado e começamos a tomar nossos apontamentos. (COSTA, 1909, p. 23)

Dessa forma a iniciação na língua começou a ser feita a partir dos apontamentos mencionados, obtidos no contato direto com falantes, e pelo estudo da doutrina cristã em nheengatu, Christu muhençáua çurimaan-uára arama nhihingatu rupi - doutrina christã destinada aos naturais do Amazonas em nhihingatu (1898) ${ }^{55}$, elaborada pelo primeiro bispo do Amazonas, Dom José Lourenço da Costa Aguiar (COSTA, 1909, p. 26).

Dom Frederico Costa narra ainda outros episódios em sua carta pastoral, à época do seu bispado, durante suas viagens a várias regiões do Amazonas. Além do relato dessas experiências, traz ao leitor a tradução de algumas orações católicas ao nheengatu, bem como a tradução do conhecido poema de Gonçalves Dias "Canção do Exílio", intitulado Ceretama uricú palmeira ${ }^{56}$ (COSTA, 1909, 171). Ademais, publica em tradução bilíngue (nheengatu/português) o Mahie Ia-munhan quau Mendariçaua ti ramé ahiqué Pahy, ou "Modo de celebrar Cazamento na auzencia do Padre" (COSTA, 1909, p. 176).

Assim como O Selvagem e a Poranduba Amazonense, os Elementos necessários para aprender o nheengatú também exerceram uma influência importante na literatura brasileira. Guimarães Rosa, ao que tudo indica, consultou a obra de Dom Frederico Costa para a composição de um longo conto intitulado Meu tio o Iauaretê $(1961)^{57}$. Talvez esta seja a obra da literatura brasileira com a maior profusão de vocábulos tupis $^{58}$.

\footnotetext{
${ }^{55}$ Assim como Dom Frederico Costa, a pretensão do primeiro bispo do Amazonas em publicar sua obra era a de atender às necessidades catequéticas da igreja, mas, diferentemente daquele, com especial atenção às comunidades ribeirinhas do rio Solimões. Na publicação de Dom Costa Aguiar consta o primeiro catecismo bilíngue nheengatu-português.

${ }^{56}$ Literalmente: "minha terra tem palmeira". Este é o primeiro verso do referido poema.

${ }^{57}$ Além de evidências no conto, sabe-se que o livro de Dom Frederico Costa fazia parte da biblioteca particular de Guimarães Rosa, hoje sob os cuidados do Instituto de Estudos Brasileiros da Universidade de São Paulo (IEB - USP).

${ }^{58}$ Vale ressaltar que "vocábulos tupis" é uma definição genérica que pode abarcar desde o tupi antigo até as línguas gerais e o nheengatu.
} 
Em Meu tio o Iauaretê tais vocábulos aparecem majoritariamente na forma do nheengatu e são intercalados com palavras que possuem o mesmo significado em português, o que confere a esse texto uma natureza bilíngue de autotradução. A mescla entre o português e o nheengatu é muito importante para o entendimento do enredo, em que um narrador mestiço (filho de pai branco e mãe índia), isolado no sertão mineiro e contratado para matar todas as onças de uma vasta região, passa por um processo de transformação física, de homem a onça. Renegando veementemente sua herança paterna e exaltando a bondade de sua mãe, cujo nome era Mar'Iara Maria, o narrador de Meu tio o Iauaretê busca resgatar os laços do seio materno, no qual a cultura e a língua indígena estavam presentes. $\mathrm{O}$ nome dado à mãe do narrador aparece em uma oração católica traduzida ao nheengatu por Dom Frederico Costa, intitulada Catú Reté Rosario, ou Bemdito Rosario ${ }^{59}$ (COSTA, 1909, p. 169).

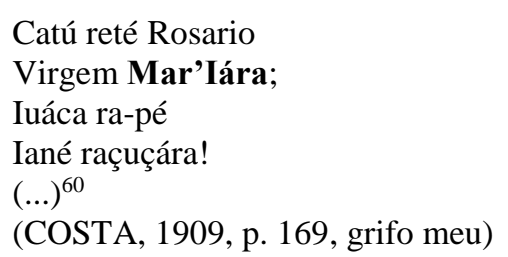

Não somente nessa relação intertextual o trabalho de Dom Frederico Costa parece ter influenciado na composição de Meu tio o Iauaretê. O mesmo registro gráfico $^{61}$ empregado no vocabulário de Elementos necessários para aprender o nheengatú é notado em algumas palavras em nheengatu registradas por Guimarães $\operatorname{Rosa}^{62}$. Sobre a importância do referido vocabulário, Frederico Edelweiss menciona que este é "o primeiro vocabulário nheengatu-português de certa extensão, publicado com o seu reverso, cuja falta era sentida de longa data" (EDELWEISS, 1969, p.191).

\footnotetext{
${ }^{59}$ Catú Reté Rosario literalmente seria traduzido por "rosário muito bom".

60 Uma possível tradução desses versos: "Bendito Rosário/ O da Virgem Maria;/ Do caminho do céu/ O nosso guia!” (ÁVILA \& TREVISAN, 2015, p. 328).

61 É válido ressaltar que há diferenças gráficas significativas entre os autores que compuseram gramáticas ou compilaram narrativas em nheengatu. Como não havia muitos registros da língua, a orientação de cada um deles variava de acordo com aquilo que ouviam dos falantes. Assim, notam-se diferenças em relação à época de produção de um estudo e à região onde os falantes/informantes estavam.

62 Guimarães Rosa, provavelmente, teve acesso a diversos materiais em tupi, devido ao fato de suas escolhas lexicais aparecerem em diferentes vocabulários. Para mais informações sobre a presença de aspectos linguísticos do tupi em Meu tio o lauaretê, consulte: Jaguanhenhém: um estudo sobre a linguagem do iauaretê (ÁVILA \& TREVISAN, 2015). Para a relização desse trabalho utilizou-se a 6a edição do livro Estas estórias, publicada em 2013 pela editora Nova Fronteira.
} 


\subsection{Grammatica da língua tupy (1923), do Pe Constantino Tastevin}

Constantino Tastevin (1890 - 1962) foi um missionário francês que viveu por muitos anos na Amazônia, na região de Tefé, onde estudou e registrou a variante do nheengatu das proximidades do rio Solimões. A edição francesa de sua gramática foi publicada em Viena, em 1910, sob o título de La langue tapïhïya - dite tupï ou ñeengatu (belle langue). A edição em português, intitulada Grammatica da língua tupy, somente fora publicada em 1923. Segundo Tastevin, nesta edição:

Reformei ligeiramente o Prefácio onde exponho novos conceitos sobre a nação dos Tapihiyas ${ }^{63}$, e também não me obriguei a traduzir ao pé da letra a edição francesa da Grammatica. Porém nos seus pontos essenciaes a obra é a mesma, e as ideias propugnadas sustentam-se aqui com a mesma convicção (...) (TASTEVIN, 1923, p. 5).

Embora considerado por Frederico Edelweiss "o melhor compêndio do tupi moderno" (EDELWEISS, 1969, p. 191), as ideias propugnadas por Tastevin no preâmbulo de seu livro foram duramente rebatidas por este filólogo em seus Estudos tupis e tupi-guaranis (EDELWEISS, 1969). A começar pelo título do livro em francês, no qual se consideram erroneamente "tupi" e "tapuia" duas formas da mesma palavra (EDELWEISS, 1969, p. 191). Considerando o que se segue:

Chamamos lingua tupy, nheẽn gatu "boa lingua", nheẽn "lingua", Awa nheẽn "lingua dos Homens", ou lingua geral brasilica, uma língua que nos tempos pre-historicos ao menos extendeu o seu dominio sobre todo o Brasil, as Guyanas, o Uruguay, o Paraguay, e parte dos paizes vizinhos: Perú, Colombia, Venezuela, Argentina. (TASTEVIN, 1969, p. 5)

percebe-se que o missionário entendia a "lingua geral brasilica" (o tupi antigo), o "awa nheẽn" (o guarani), o que ele chama de "nheẽn" (a lingua geral do sul) e o "nheẽn gatu" (a língua geral do norte) como dialetos de uma mesma língua, falada em território muito extenso. Essa concepção equivocada devido ao pouco conhecimento da bibliografia tupi-guarani, segundo Edelweiss (1969, p. 192), fez com que Tastevin considerasse tanto a língua que Anchieta descreveu no século XVI como a que estudava no século XX, o nheengatu, variantes de uma mesma língua. Segundo o missionário francês, a língua que descrevia, deturpada pelos missionários jesuítas - entre os quais Anchieta e Figueira -, influenciados pelo "mecanismo das linguas latinas ou neo latinas", nunca

\footnotetext{
${ }^{63}$ Esta é a palavra utilizada pelo padre francês para se referir aos "tapuios", índios em contato com os brancos.
} 
havia sido devidamente aprofundada (TASTEVIN, 1923, p. 9). Como notava diferenças entre a descrição gramatical dos antigos missionários e as formas às quais estava exposto, julgava ingenuamente que tais registros haviam sido corrompidos pelos primeiros estudiosos da língua.

Não obstante as críticas a esse trabalho, ele apresenta uma rica gramática e um vocabulário nheengatu/português, vocabulário este mais alentado que o de Dom Frederico Costa.

\subsection{Lendas em Nheêngatu e em Portuguêz (1926), de Antônio Brandão de}

\section{Amorim}

Antônio Brandão de Amorim (1865-1926), "nasceu em Manaus, filho de um rico comerciante português radicado no Amazonas", e foi um apaixonado estudioso de narrativas de tradição oral amazônicas (FREIRE, 2011, p. 145). Desenvolveu suas pesquisas no mesmo período em que Barbosa Rodrigues e Ermanno Stradelli também se debruçavam sobre questões da Amazônia, “em pleno florescimento do Museu Botânico de Manaus" (LOUREIRO, 1987, s/ pág.), onde trabalhou como secretário de Barbosa Rodrigues (FREIRE, 2011, p. 145). Seu livro, Lendas em Nheêngatu e em Portuguêz, foi publicado na Revista do Instituto Histórico e Geográfico Brasileiro em $1926^{64}$, após a morte de Brandão de Amorim naquele mesmo ano.

Nesse livro há uma reunião de textos que contemplam mitos fundadores (sobre a origem de alguns povos), lendas de guerras (sobre a ocupação de territórios), contos de amor e mitos que explicam a origem de animais. Tais narrativas foram recolhidas por Maximiano José Roberto, indígena falante de nheengatu, considerado por Rodrigues, Amorim e Stradelli a maior autoridade intelectual no assunto, e revisadas e traduzidas por Brandão de Amorim. No entanto, as 35 narrativas em edição bilíngue que compõem o livro Lendas em Nheêngatu e em Portuguêz foram publicadas pela família de Amorim na revista do IHGB somente com o nome de Brandão de Amorim, publicação em que Maximiano José Roberto não levou crédito algum (FREIRE, 2011, p. 145).

\footnotetext{
${ }^{64}$ Este livro foi novamente publicado em 1987, pela Comissão Cultural do Fundo Editorial da Associação Comercial do Amazonas, em Manaus.
} 
$\mathrm{Na}$ literatura brasileira, a contribuição dessa publicação aparece no poema narrativo Cobra Norato (1931), de Raul Bopp ${ }^{65}$. A obra se insere no contexto da antropofagia modernista, fruto da pesquisa de Bopp a respeito da lenda amazônica da Cobra Grande ${ }^{66}$, durante o período em que morou em Belém. Foi nessa época, tendo viajado muito pela Amazônia, que tomou conhecimento do trabalho de Brandão de Amorim, cuja obra "passava de mão em mão como um manuscrito ainda não impresso" (SÁ, 2012, p. 282).

Em seu livro intitulado Vida e morte da antropofagia, Bopp menciona a descoberta e a importância de Lendas em Nheêngatu e em Portuguêz:

Uma ocasião, [Alberto Andrade Queiroz] mostrou-me trabalhos avulsos de Antônio Brandão de Amorim (1865-1936), de um forte sabor indígena. Foi uma revelação. Eu não havia lido nada mais delicioso. Era um idioma novo. A linguagem tinha às vezes uma grandiosidade bíblica...

Essas leituras me conduziram a um novo estado de sensibilidade. Alarguei instintivamente a visão que formava das coisas. Abeirei-me das falas rurais, de uma deliciosa formação sintática (BOPP apud SÁ, 2012, 283).

Em Cobra Norato $^{67}$ essa influência é muito mais perceptível no plano da linguagem do que no plano do enredo (SÁ, 2012, p. 284), isso é o que se vê, por exemplo, no uso do vocativo "- Ah compadre Tatu” (BOPP, 2013, p. 177) ${ }^{68}$, “Ai compadre” (p. 180), “- Mar fica longe, compadre?” (p. 185), de verbos no diminutivo, como "E eu virei vira-mundo/ para ter um querzinho" (p. 180), "Então esperazinho um pouco" (p. 206), "Quero estarzinho com ela” (p. 210), na reduplicação verbal - “Ai o capim pirixi/ Rema Rema deste lado” (p. 181), “Garcinha branca voou voou...” (p. 184) - e na utilização frequente de onomatopeias - "Cai lá adiante um pedaço de pau seco:/ Pum” (p. 171), “Tiúg... Tiúg... Tiúg.../ Twi. Twi-twi” (p.173), “Uei! Aqui vai passando

\footnotetext{
65 Além de Bopp, a linguagem empregada por Mário de Andrade em Macunaíma foi influenciada por Lendas em Nheêngatu e em Portuguêz. Entre as evidências que corroboram isso, a utilização do verbo "brincar" para denotar o ato sexual e as repetições de sílabas em verbos com aspecto frequentativo, como "cantacantando" e "falafalando" (SÁ, 2012, p. 282).

${ }^{66}$ A lenda da Cobra Grande, ou Boiúna (que literalmente significa "cobra preta"), está relacionada ao nome Norato. Segundo Câmara Cascudo, a narrativa da cobra Norato é:

uma das lendas mais conhecidas no extremo norte brasileiro, Amazonas e Pará. Uma mulher indígena tomava banho no paraná do Cachoeiri, entre o rio Amazonas e o rio Trombetas, município de Óbidos, Pará, quando foi engravidada pela Cobra Grande. Nasceram um menino e uma menina, que a mãe, a conselho do pajé, atirou ao rio, onde se criaram, transformados em cobras d'água. O menino, Honorato, Norato, e a menina, Maria Caninana, andavam sempre juntos. Norato era bom e Maria, má (CASCUDO apud SÁ, 2012, p. 284).

${ }^{67}$ Utilizou-se nesta dissertação a seguinte edição de Cobra Norato: BOPP, Raul. (2013) Poesia completa de Raul Bopp. Organização de Augusto Massi. 2a edição. Rio de Janeiro: José Olympio.

${ }^{68}$ Todas as citações deste trecho referem-se ao livro Cobra Norato, de Raul Bopp, publicado em 2013 pela editora José Olympio.
} 
um riozinho/ de águas órfãs fugindo/ - Ai glu-glu-glu" (p. 186), "Pajé tonteou Se acocorou Foi-se sumindo/ assobiando baixinho fiu... fiu... fiu..." (p. 201), "Uma árvore telegrafou para outra: psi psi psi” (p. 203), “- Devagar/ que chão duro dói chô chô” (p. 206). Esses recursos, presentes em Amorim (tanto em nheengatu como nas traduções ao português) e reproduzidos por Bopp, vivificam a oralidade da língua portuguesa tipicamente amazônica, bastante influenciada pelo nheengatu. Na opinião de Carlos Drummond de Andrade, Cobra Norato é "o mais brasileiro de todos os livros de poemas de poetas brasileiros, escritos em qualquer tempo" (apud TUFIC, 1987, s/ pág.).

\subsection{Vocabularios da lingua geral portuguez-nheêngatú e nheêngatú- portuguez (1929), do Conde Ermanno Stradelli}

Ermanno Stradelli (1852-1926) nasceu na Itália em uma família nobre, aos 27 anos fez a sua primeira viagem ao Brasil, como membro da Reale Società Geografica Italiana. Após essa viagem, regressou à Itália a fim de terminar seus estudos em Direito. Retornaria ao Brasil em 1888, dessa vez instalando-se definitivamente no Estado do Amazonas, onde trabalhou como promotor público de Tefé e Lábrea; faleceu, em 1926, devido à lepra, no leprosário de Umirizal, em Manaus (BROTHERSTON \& SÁ, 2014, p. 11). Stradelli, que se naturalizou brasileiro em 1893, dedicou grande parte de sua vida à elaboração de seu vocabulário, que só foi publicado em $1929^{69}$, três anos após a sua morte, na Revista do Instituto Histórico e Geográfico Brasileiro.

A sua obra mais conhecida é "mais do que um simples vocabulário, o volume pode ser descrito, sem exagero, como uma enciclopédia amazônica" (BROTHERSTON \& SÁ, 2014, p. 13). Esse trabalho de caráter enciclopédico traz em suas 768 páginas informações sobre diversas categorias do conhecimento, entre as quais: "fauna, flora, medicina, pesca, caça, agricultura, astronomia, história política, rituais e costumes, além de literatura e folclore indígena e caboclo" (BROTHERSTON \& SÁ, 2014, p. 13).

A elaboração do grande vocabulário de Stradelli, ou dicionário, recebeu a valiosa ajuda de Maximiano José Roberto, o mesmo que colaborou nos trabalhos de Barbosa Rodrigues e Brandão de Amorim. "Maximiano passou uma grande parte de sua

\footnotetext{
69 Ao longo desta dissertação farei menção à obra máxima de Ermanno Stradelli por meio da edição publicada em 2014 pela Ateliê Editorial.
} 
vida recolhendo histórias em nheengatu na região do Uaupés - histórias que eventualmente seriam publicadas sob o nome de um ou outro dos três estudiosos" (BROTHERSTON \& SÁ, 2014, p. 12).

Pode-se considerar o dicionário de Stradelli como uma obra sui generis, visto que pode ser lido não apenas como uma obra de consulta, mas também como um relato de sua experiência na Amazônia. Veja-se, por exemplo, a definição do verbete iисиаси (jejum):

\begin{abstract}
Jejuado. O indígena, pode-se dizer, passa uma grande parte da vida a jejuar. Começa a jejuar quando chega a puberdade, jejua na véspera das festas instituídas por Jurupari $^{70}$, o Legislador indígena; jejua antes de casar; o casado jejua todas as vezes que a própria mulher é menstruada, quando esta pare $[s i c]$ e durante o resguardo a que ele fica submetido, quando os filhos estão doentes e não sei mais em que circunstâncias. Se aos jejuns rituais porém juntarmos os forçados, que também não são poucos, precisa convir que eu não exagero dizendo que passa a vida a jejuar. Disso pois, talvez, a razão por que, quando tem, come à tripa forra. É para refazer o tempo perdido. (STRADELLI, 2014, p. 387)
\end{abstract}

Além de um extenso vocabulário (o maior que foi feito até agora), Stradelli apresenta um "Esboço de Gramática Nheengatu” e uma "Coleção de Trechos Nheengatu", narrativas já publicadas nos livros de Couto de Magalhães, Constantino Tastevin, Lourenço da Costa Aguiar, Frederico Costa, Barbosa Rodrigues e três lendas que ele afirma serem inéditas ${ }^{71}$, recolhidas por Maximiano José Roberto e transcritas por Brandão de Amorim, todas elas com tradução ao português.

\footnotetext{
70 Stradelli também publicou um importante texto chamado "Lenda do Jurupari", recolhido em nheengatu por Maximiano José Roberto e publicado em italiano pelo conde, como La Leggenda dell' Jurupary, em 1890, sete anos após a sua chegada ao Brasil (BROTHERSTON \& SÁ, 2014, pp. 12 e 19). Segundo o historiador José Ribamar Bessa Freire, Stradelli "foi o responsável pela desconstrução da imagem satanizada de Jurupari, herói civilizador representado durante três séculos pelos missionários e cronistas como um diabo ameríndio" (FREIRE, 2011, p. 105).

${ }^{71}$ Como a publicação de Brandão de Amorim saiu três anos antes que a de Stradelli, duas dessas três lendas já constavam no livro daquele autor.
} 


\section{Ferramentas tradutórias e para a análise da tradução}

\subsection{Sobre a ortografia}

Como o nheengatu é uma língua de tradição oral que sobrevive até hoje basicamente por meio dessa modalidade, os registros gráficos utilizados nos textos em que ela foi grafada variam de época para época, de região para região e de autor para autor. A orientação dos autores que escreveram em e sobre o nheengatu era guiada principalmente pelo que ouviam "da boca" dos falantes e pela capacidade de identificação do que lhes era dito. Muito do que se fez sobre o nheengatu, desde o final do século XIX e começo do XX até os dias atuais, centra-se justamente na tentativa de reproduzir no papel o nheengatu em sua modalidade oral. A despeito de sua oficialização em 2002 no município de São Gabriel da Cachoeira, o nheengatu, até o presente momento, ainda se encontra distante de uma tradição escrita, o que se reflete na falta de padronização ortográfica da língua.

Desse modo, o registro gráfico escolhido para a tradução de Le Petit Prince ao nheengatu seguirá as mesmas orientações dos trabalhos que vêm sendo desenvolvidos na Universidade de São Paulo ${ }^{72}$, os quais, além de se balizarem pelos registros antigos da língua, confrontando-os com a língua em seu estado atual, seguem tendências ortográficas atualmente utilizadas no Rio Negro.

\subsubsection{Ortografia adotada na tradução de Le Petit Prince ao nheengatu}

Eis as principais considerações sobre a ortografia adotada neste trabalho:

\footnotetext{
72 Além da publicação de duas edições do Curso de Língua Geral (2011; 2016), elaborado pelo professor Eduardo de Almeida Navarro, já foram realizados dois importantes trabalhos de tradução ao nheengatu na Universidade de São Paulo, um dos quais é uma produção coletiva feita pelos alunos da disciplina Tupi IV em 2012, trabalho este que contempla traduções de textos de Esopo, La Fontaine, Monteiro Lobato, entre outros autores. O outro trabalho consiste na tradução do conto infantil $A$ terra dos meninos pelados, de Graciliano Ramos, feita por Marcel Twardowsky Ávila, cuja dissertação de mestrado, intitulada "Estudo e prática da tradução da obra infantil $A$ terra dos meninos pelados, de Graciliano Ramos, do português para o nheengatu", foi defendida em março de 2016. Tanto as traduções dos alunos de Tupi IV como a de Ávila ainda não foram publicadas em livro.
} 
- Acentuação gráfica:

Acentuam-se todas as palavras proparoxítonas: pitérupi (no meio de), árupi (sobre) etc.

Acentuam-se todas as palavras oxítonas: kurasí (sol), ixé (eu), turusú (grande) etc.

Acentuam-se as vogais tônicas que formam hiato: kwaíra (pequeno), suí (de; desde), suú (animal; morder) etc.

Não se acentuam as palavras paroxítonas, exceto as que possuem vogais tônicas que formam hiato: puranga (bonito), putira (flor), iwaka (céu) etc.

Acentuam-se os monossílabos tônicos: pú (mão), pé (caminho), í (vez) etc.

Não se acentuam os monossílabos átonos: $t i$ (não), se (meu), $i$ (seu, sua; dele, dela) etc.

Acentuam-se todos os ditongos oxítonos: yeréu (virar), akayú (ano) etc.

As vogais que levam til ( ) geralmente são tônicas, mas, em raras exceções, se a sílaba tônica for outra, esta receberá acento gráfico: pisãwéra (pedaço), nhãrú (bravo) etc.

\section{- Notas sobre a ortografia:}

Nos ditongos crescentes (semivogal + vogal), no lugar de "i" e "u", utilizam-se “y” e "w" na representação das semivogais: yakira (verde) e watá (andar).

Nos ditongos decrescentes (vogal + semivogal), utilizam-se "i" e " $u$ " na representação das semivogais: maité (achar, pensar) e sikindáu (fechar).

Apenas os sufixos -itá, que indica a desinência de plural, e -íma, que indica ausência e se traduz ao português por "sem" ou "des-", são acompanhados de hífen (-): putira-itá (flores) e iwitú-íma (sem vento).

A vogal "o" é substituída pela vogal "u" nas palavras adaptadas ao sistema fonético-fonológico do nheengatu ${ }^{73}$ : morar $\rightarrow$ murari; pano $\rightarrow$ panu.

Verbos da língua portuguesa adaptados ao sistema fonético-fonológico do nheengatu recebem o acréscimo da letra "i" em sua terminação: vender $\rightarrow$ venderi; enganar $\rightarrow$ ganani.

\footnotetext{
${ }^{73} \mathrm{O}$ nheengatu apresenta quatro vogais orais $-a, e, i, u-e$ quatro vogais nasais $-\tilde{a}, \tilde{e}, \tilde{I}, \tilde{u}$.
} 
O sistema fonético-fonológico do nheengatu não possui os fonemas correspondentes aos sons das letras "f", "l”, "rr", "v", “z” e "d" $\rightarrow$ panera; cavalo $\rightarrow$ cawaru; camarada $\rightarrow$ camarara.

\title{
3.2. Modalidades de tradução
}

Alguns dos termos presentes nos comentários a respeito de minha tradução relacionam-se à abordagem técnica proposta por Francis Henrik Aubert em Modalidades de tradução: teoria e resultados (AUBERT, 1998). Tal abordagem remonta ao modelo de Vinay e Darbelnet (1958), que foi adaptado, segundo Aubert, com a finalidade de contribuir com a análise quantitativa de dados textuais, por meio de uma "descrição comparada das estruturas de superfície entre um texto fonte e seu texto meta correspondente" (AUBERT, 1998, p. 110). Em outras palavras:

\begin{abstract}
Esse modelo foi adaptado aos objetivos de um projeto específico, tendo por finalidade a descrição de "grau de diferenciação" entre o texto original e o texto traduzido [...] Neste enfoque, o modelo não mais pretendia descrever procedimentos e sim produtos, razão pela qual a designação "procedimentos de tradução" foi substituída por "modalidades de tradução". (AUBERT, 1998, p. 103)
\end{abstract}

Com base no estudo de Aubert, na análise de minha tradução, utilizarei, com o propósito de classificar as estratégias tradutológicas adotadas por mim, alguns termos empregados para descrever as modalidades de tradução. A partir dessa delimitação, as considerações sobre a tradução estão organizadas por meio de modalidades relacionadas tanto a aspectos de natureza gramatical como a elementos culturais próprios de determinada visão de mundo.

De acordo com a proposta de Vinay e Darbelnet, os procedimentos de tradução iriam de um "grau zero" da tradução, o empréstimo, até o seu oposto, a adaptação (VINAY \& DARBELNET apud AUBERT, 1998, p. 102). Nessa escala, alguns procedimentos podem ser associados à tradução "direta" (os mais próximos do empréstimo e, por conseguinte, do texto-fonte), e outros, à tradução "indireta" (os que se aproximam mais da adaptação e, assim, são mais distantes do texto-fonte) (AUBERT, 1998, p. 102 e 110). É válido ressaltar que Aubert, em seu modelo adaptado de Vinay e Darbelnet, menciona 13 modalidades de tradução - omissão, transcrição,

\footnotetext{
${ }^{74}$ A letra " $d$ " ocorre em nheengatu apenas na forma "nd", como em manduari (pensar; lembrar).
} 
empréstimo, decalque, tradução literal, transposição, explicitação/implicitação, modulação, adaptação, tradução intersemiótica, erro, correção e acréscimo (1998, pp. 105-110).

Nos comentários sobre a tradução de Le Petit Prince ao nheengatu não ficarei preso aos nomes dessas modalidades, visto que em alguns momentos mais de uma delas aparecerão, ainda que com nomes diferentes, nas seções em que a análise foi organizada - estrangeirismos, neologismos, circunlóquios e questões culturais.

Ademais, como analisarei uma tradução de minha autoria, pretendo não apenas situar o leitor sobre o produto final da tradução (a escolha final de um termo ou de uma construção sintática) mas também mostrar, quando possível, o caminho que percorri até essa escolha. Assim, conduzirei meu texto de forma semelhante ao de Paulo Henriques Britto em seu estudo Tradução e Criação (1999), no qual ele autoanalisa uma de suas traduções, mostrando ao público leitor suas hesitações, escolhas lexicais que foram substituídas e depois novamente retomadas e as influências que o seu repertório cultural exerceu no ato tradutório. 
4. Muruxawamirĩ (tradução integral da obra Le Petit Prince ao nheengatu) $)^{75}$

1 - Lorsque j'avais six ans j'ai vu, une fois, une magnifique image, dans un livre sur la forêt vierge qui s'appelait Histoires vécues.

1 - Mairamé arikú puyepé akayú amaã, yepé ara, yepé sangawa amurupí retana, yepé papera resé kaawasú resewara sera waá Mbeusawa uyusasá ana waá-itá.

2 - Ça représentait un serpent boa qui avalait un fauve.

2 - Aé umukameẽ yepé buyawasú umukuna uikú waá yepé suú kaapura.

3 - Voilà la copie du dessin.

3 - Xukúi sangawa.

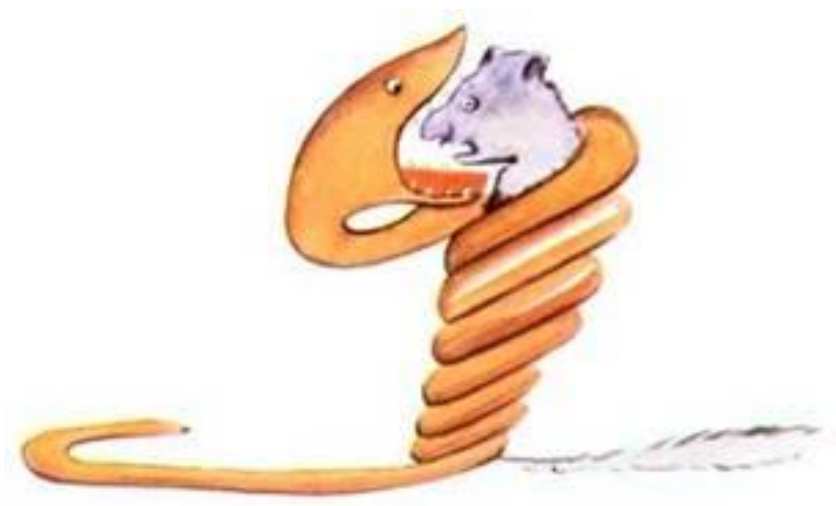

4 - On disait dans le livre: "Les serpents boas avalent leur proie tout entière, sans la mâcher. Ensuite ils ne peuvent plus bouger et ils dorment pendant les six mois de leur digestion."

4 - Papera unheẽ: "Buyawasú-itá umukuna aintá rimiara pawa usuú-suú-íma aintá. Asuí aintá ti ukataka-kwáu, aintá ukíri puyepé yasí aintá apú pukusawa."

5 - J'ai alors beaucoup réfléchi sur les aventures de la jungle et, à mon tour, j'ai réussi, avec un crayon de couleur, à tracer mon premier dessin.

5 - Aramé amanduari retana kaá mbeusawa-itá resé asuí, se rupí tẽ, amunhãkwáu, yepé pinimasara rupiara irumu, se yepesawa kwatiarisawa.

6 - Mon dessin numéro 1 . Il était comme ça:

6 - Se yepesawa kwatiarisawa. Yawé tẽ upitá:

\footnotetext{
${ }^{75}$ A edição de Le Petit Prince utilizada nesta dissertação e reproduzida a seguir foi publicada em 1999 pela editora Gallimard. No entanto a ordem de algumas ilustrações foi alterada a fim de facilitar a associação entre elas e o texto.
} 


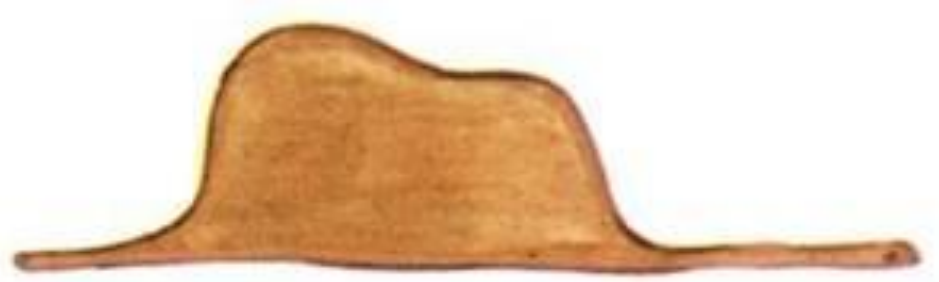

7 - J'ai montré mon chef-d'œuvre aux grandes personnes et je leur ai demandé si mon dessin leur faisait peur.

7 - Amukameẽ se munhangawa puranga piri mira-itá turusú ana waá-itá supé, asuí apurandú aintá suí sa se kwatiarisawa umusikié aintá.

8 - Elles m’ont répondu: "Pourquoi un chapeau ferait-il peur?"

8 - Aintá usuaxara kwayé-ntu: "Marã taá maã yepé xapewa umusikié?"

9 - Mon dessin ne représentait pas un chapeau.

9 - Se kwatiarisawa ti umukameẽ yepé xapewa.

10 - Il représentait un serpent boa qui digérait un éléphant.

10 - Aé umukameẽ yepé buyawasú i apú waá erepanti kwera resewara.

11 - J'ai alors dessiné l'intérieur du serpent boa, afin que les grandes personnes puissent comprendre.

11 - Aramé akwatiari buyawasú i pira kwara rupí mira-itá turusú tá umaã-kwáu arama puranga piri.

12 - Elles ont toujours besoin d'explications.

12 - Ti ramé yamusakakanga puranga pawa, aintá ti upisika puranga.

13 - Mon dessin numéro 2 était comme ça:

13 - Yawé upitá se mukũisáwa kwatiarisawa:

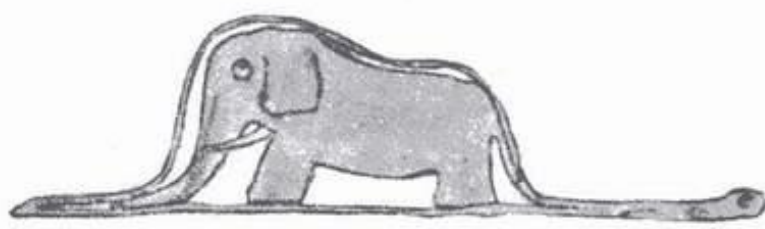

14 - Les grandes personnes m'ont conseillé de laisser de côté les dessins de serpents boas ouverts ou fermés, et de m'intéresser plutôt à la géographie, à l'histoire, au calcul et à la grammaire. 
14 - Mira-itá turusú tá umungitá ixé se resarái arama buyawasú kwatiarisawa-itá suí, ayumbué arama puranga piri iwí-kwausawa, mirasawa-itá marandua, paparisawa asuí yané nheenga.

15 - C'est ainsi que j'ai abandonné, à l'âge de six ans, une magnifique carrière de peintre.

15 - Yawé, puyepé akayú irumu, axari se suí yepé puranga murakí kwatiarisara yawé.

16 - J'avais été découragé par l'insuccès de mon dessin numéro 1 et de mon dessin numéro 2.

16 - Se rimutara uyaruka nhaãsé mira-itá turusú ti uwasemu se kwatiarisawa-itá puranga.

17 - Les grandes personnes ne comprennent jamais rien toutes seules, et c'est fatigant, pour les enfants, de toujours et toujours leur donner des explications...

17 - Mira-itá turusú ti usika tá ukwáu nẽ maã aintá rupí tẽ, sesewara taína-itá upitá tá kweré retana, nhaãsé, panhẽ mairamé, tá urikuté umbué pawa mira-itá turusú supé.

18 - J'ai donc dû choisir un autre métier et j'ai appris à piloter des avions.

18 - Aramé arikuté aparawaka amú murakí asuí ayumbué atiari pepusantá.

19 - J'ai volé un peu partout dans le monde.

19 - Awewé ana xinga Iwí pawa ara rupí.

20 - Et la géographie, c'est exact, m'a beaucoup servi.

20 - Iwí-kwausawa, supí, upitimũ retana ixé.

21 - Je savais reconnaître, du premier coup d'œil, la Chine de l'Arizone.

21 - Aramé yeperesé amaã-kwáu amurupí China Arizona suí.

22 - C'est très utile, si l'on s'est égaré pendant la nuit.

22 - Kwá upitimũ retana mairamé yayusupari pituna ramé.

23 - J'ai ainsi eu, au cours de ma vie, des tas de contacts avec des tas de gens sérieux.

23 - Yawé, se rikwesawa pukusawa, akwáu ana siía mira musarái-íma-wera waáitá.

24 - J'ai beaucoup vécu chez les grandes personnes. Je les ai vues de très près. Ça n'a pas trop amélioré mon opinion.

24 - Aikú ana retana mira-itá turusú irumu. Akwáu aintá puranga retana, ma kwá ti upitimũ retana ixé awasemu arama aintá mira katú piri. 
25 - Quand j'en rencontrais une qui me paraissait un peu lucide, je faisais l'expérience sur elle de mon dessin numéro 1 que j'ai toujours conservé.

25 - Mairamé asuantí yepé mira turusú ukwawara xinga waá, apuranduwera i suí se rangawa yepesawa resewara, amukaturú rẽ waá se irumu.

26 - Je voulais savoir si elle était vraiment compréhensive.

26 - Akwáu-putari sa aé ukwawara tẽ.

27 - Mais toujours elle me répondait: "C'est un chapeau".

27 - Ma, panhẽ mairamé, nhaã mira usuaxara ixé arama: “Kwá yepé xapewa”.

28 - Alors je ne lui parlais ni de serpents boas, ni de forêts vierges, ni de d'étoiles. Je me mettais à sa portée.

28 - Aramé ti ana apurungitá buyawasú resé, nẽ kaawasú resé, nẽ yasitatá resé. Amunhã-ntu i yawé.

29 - Je lui parlais de bridge, de golf, de politique et de cravates.

29 - Apurungitá tetama-itá ruixawa-itá resé asuí muamundewa-itá resé.

30 - Et la grande personne était bien contente de connaître un homme aussi raisonnable...

30 - Yawé nhaã mira turusú surí retana upitá, ukwáu resewara yepé apigawa mayé i yawé...

1 - J'ai ainsi vécu seul, sans personne avec qui parler véritablement, jusqu'à une panne dans le désert du Sahara, il y a six ans.

1 - Sesewara aikú yepenhũ, nẽ awá irumu apurungitá arama supí, té ara mairamé se pepusantá upena yepé tetama mira-íma upé, sera waá Saara, aikwé ana puyepé akayú.

2 - Quelque chose s'était cassé dans mon moteur.

2 - Manungara upena uikú se pepusantá mukatakasara upé.

3 - Et comme je n'avais avec moi ni mécanicien, ni passagers, je me préparai à essayer de réussir, tout seul, une réparation difficile.

3 - Mayé ti aikwé nẽ awá se irumu, arikuté amungaturú se pepusantá se rupí tẽ.

4 - C'était pour moi une question de vie ou de mort.

4 - Nhaã, ixé arama, se rikwesawa u se manũsawa. 
5 - J'avais à peine de l'eau à boire pour huit jours.

5 - Arikú-ntu ií aú arama pumusapiri ara pukusawa.

6 - Le premier soir je me suis donc endormi sur le sable à mille milles de toute terre habitée.

6 - Yepesawa pituna ramé akiri iwikuí árupi, apekatú retana mayewa tetama suíntu mamé mira-itá uikú.

7 - J'étais bien plus isolé qu'un naufragé sur un radeau au milieu de l'oceán.

7 - Yawé aikú yepenhũ piri awá uyusupari waá suí yepé igaramirĩ irumu paranãwasú pitérupi.

8 - Alors vous imaginez ma surprise, au lever du jour, quand une drôle de petite voix m’a réveillé.

8 - Aramé pemanduari mayé tẽ se akanhemu, mairamé, kwemaité, yepé nheengamirĩ amurupí umupaka ixé.

9 - Elle disait: ...

9 - Unheẽ: ...

10 - "S'il vous plaît... dessine-moi un mouton!

10 - - Ayururéu ne suí... rekwatiari ixé arã yepé suumé ${ }^{76}$ mimbira!

11 - - Hein!

11 - - Maã taá?

12 - - Dessine-moi un mouton..."

12 - - Rekwatiari ixé arã yepé suumé mimbira...

13 - J'ai sauté sur mes pieds comme si j'avais été frappé par la foudre. J'ai bien frotté mes yeux. J'ai bien regardé.

13 - Apuri se akanhemu mayé yepé uerawa uwari ramé maã se árupi, akitika se resá asuí amaã katú sesé.

14 - Et j'ai vu un petit bonhomme tout à fait extraordinaire qui me considérait gravement.

14 - Aramé amaã yepé apigawamirĩ amurupí retana umanhana uikú waá ixé.

15 - Voilà le meilleur portrait que, plus tard, j'ai réussi à faire de lui.

15 - Xukúi sangawa puranga piri amunhã-kwáu waá sesé asuiwara.

16 - Mais mon dessin, bien sûr, est beaucoup moins ravissant que le modèle.

\footnotetext{
${ }^{76}$ Yepé suú i nheenga waá "mé".
} 
16 - Ma nhaã apigawamirĩ, supí, puranga piri katú se kwatiarisawa suí.

17 - Ce n'est pas ma faute.

17 - Ti usemu kwayé se resewara-ntu.

18 - J'avais été découragé dans ma carrière de peintre par les grandes personnes, à l'âge de six ans, et je n'avais rien appris à dessiner, sauf les boas fermés et les boas ouverts.

18 - Mairamé arikú puyepé akayú mira-itá turusú uyuka se suí se rimutara ti arama apurakí kwatiarisara yawé, sesewara ayumbué-ntu akwatiari buyawasú-itá.

19 - Je regardai donc cette apparition avec des yeux tout ronds d'étonnement.

19 - Amaã-maã nhaã apigawamirĩ resé se resá-itá irumu tá teresemu akanhemusawa irumu.

20 - N'oubliez pas que je me trouvais à mille milles de toute région habitée.

20 - Té pe resarái ixé aikú aramé apekatú retana mayewa tetama suí-ntu mamé mira-itá uikú.

21 - Or mon petit bonhomme ne me semblait ni égaré, ni mort de fatigue, ni mort de faim, ni mort de soif, ni mort de peur.

21 - Ma nhaã apigawamirĩ ti uyukwáu mayé awá uyusupari waá yawé, nẽ i kweré retana nungara, nẽ i yumasí retana, nẽ i isí retana, nẽ sikiesawa turusú irumu.

22 - Il n'avait en rien l'apparence d'un enfant perdu au milieu du désert, à mille milles de toute région habitée.

22 - Aé ti tẽ yepé kurumimirĩ nungara uyusupari waá yepé tetama mira-íma upé, apekatú retana mayewa tetama suí-ntu mamé mira-itá umurari.

23 - Quand je réussis enfin à parler, je lui dis:

23 - Mairamé apurungitá-kwáu, anheẽ i xupé:

24 - "Mais... qu'est-ce que tu fais là?"

24 - - Ma... maã taá remunhã iké?

25 - Et il me répéta alors, tout doucement, comme une chose très sérieuse:

25 - Aramé unheẽ amú í ixé arama, kuíri merupí, unheẽ waá yawé manungara satambika retana:

26 - "S'il vous plaît... dessine-moi un mouton..."

26 - - Ayururéu ne suí... rekwatiari ixé arã yepé suumé mimbira!

27 - Quand le mystère est trop impressionant, on n’ose pas désobéir.

27 - Mairamé usika manungara ti tẽ yakwáu waá, puranga piri yapusú aé. 
28 - Aussi absurde que cela me semblât à mille milles de tous les endroits habités et en danger de mort, je sortis de ma poche une feuille de papier et un stylographe.

28 - Apekatú retana mayewa tetama suí-ntu mamé mira-itá uikú asuí sikiesawa irumu manusawa suí, nhaã pawa akangaiwasawa nungara. Ma yawé tẽ apisika yepé papera asuí yepé pinimasara rupiara.

29 - Mais je me rappelai alors que j'avais surtout étudié la géographie, l'histoire, le calcul et la grammaire et je dis au petit bonhomme (avec un peu de mauvaise humeur) que je ne savais pas dessiner.

29 - Ma, aramé tẽ, amanduari ayumbué-ntu puranga iwí-kwausawa, mirasawa-itá marandua, paparisawa asuí yané nheenga. Asuí anheẽ apigawamirĩ supé (se piaíwa xinga aikú) ti akwatiari-kwáu.

30 - Il me répondit:

30 - Aé usuaxara ixé arama:

31 - "Ça ne fait rien. Dessine-moi un mouton."

31 - - Puranga pá. Rekwatiari ixé arã yepé suumé mimbira.

32 - Comme je n'avais jamais dessiné un mouton je refis, pour lui, l'un des deux seuls dessins dont j'étais capable. Celui du boa fermé.

32 - Mayé nẽ mairamé akwatiari ana kwera yepé suumé mimbira, amunhã i xupé yepé sangawa akwáu katú waá: se yepesawa kwatiarisawa.

33 - Et je fus stupéfait d'entendre le petit bonhomme me répondre:

33 - Ma se akanhemu apitá mairamé asendú nhaã apigawamirĩ unheẽ ixé arama:

34 - "Non! Non! Je ne veux pas d'un éléphant dans un boa. Un boa c'est très dangereux, et un éléphant c'est très encombrant. Chez moi c'est tout petit. J'ai besoin d'un mouton. Dessine-moi un mouton."

34 - - Umbaá, umbaá! Ti aputari yepé erepanti kwera yepé buyawasú kwara upé. Buyawasú i yawaité retana asuí erepanti turusú retana. Mamé ixé amurari panhẽ maã mirĩ. Uwatari tẽ ixé arã yepé suumé mimbira. Rekwatiari ixé arã yepé suumé mimbira.

35 - Alors j’ai dessiné.

35 - Aramé akwatiari.

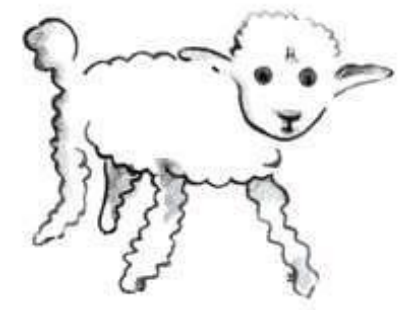


36 - Il regarda attentivement, puis:

36 - Umaã katú asuí unheẽ:

37 - "Non! Celui-là est déjà très malade. Fais-en un autre."

37 - - Umbaá! Kwá i maasí retana. Rekwatiari amú ixé arã.

38 - Je dessinai:

38 - Aramé akwatiari.

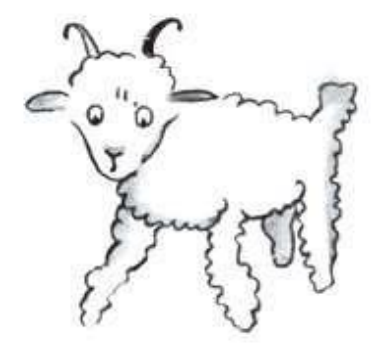

39 - Mon ami sourit gentiment, avec indulgence:

39 - Se rumuara upuká seẽ:

40 - "Tu vois bien... ce n'est pas un mouton, c'est un bélier. Il a des cornes..."

40 - - Rekwáu tẽ kwá ti yepé suumé mimbira. Kwá yepé suumé waimĩ. Aé urikú i aka-itá.

41 - Je refis donc encore mon dessin:

41 - Aramé amunhã yuíri se kwatiarisawa:

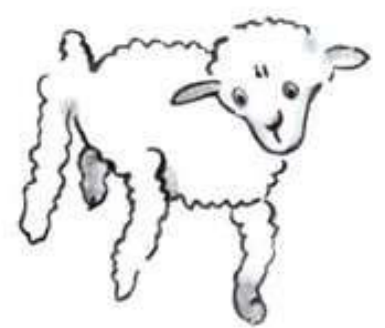

42 - Mais il fut refusé, comme les précédents:

42 - Ma, mayé amú kwatiarisawa-itá yawé, muruxawamirĩ ti uputari nhaã yuíri:

43 - "Celui-là est trop vieux. Je veux un mouton qui vive longtemps."

43 - - Kwá waimĩ retana. Ixé aputari yepé suumé mimbira upitá waá se irumũ siía ara rupí.

44 - Alors, faute de patience, comme j'avais hâte de commencer le démontage de mon moteur, je griffonnai ce dessin-ci: 
44 - Aramé, mayé susanga-íma ana aikú asuí ti maã aikupukú-putari amungaturú arama se pepusantá mukatakasara, amunhã kutara nungara amú kwatiarisawa.

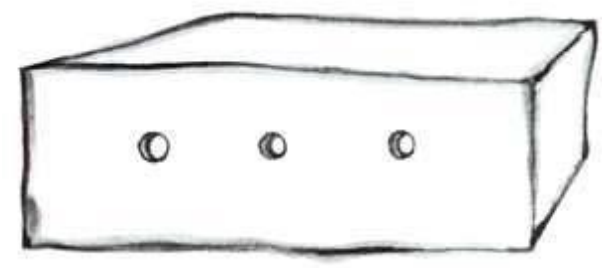

45 - Et je lançai:

45 - Asuí anheẽ:

46 - "Ça c'est la caisse. Le mouton que tu veux est dedans."

46 - - Kwá yepé patuá. Suumé mimbira reputari waá uikú patuá kwara upé.

47 - Mais je fus bien surpris de voir s'illuminer le visage de mon jeune juge:

47 - Ma se akanhemu retana mairamé amaã uwerá nhaã kurumĩ purandusara ruá.

48 - “C'est tout à fait comme ça que je le voulais! Crois-tu qu'il faille beaucoup d'herbe à ce mouton?

48 - - Yawé tẽ aputari waá! Remaité será kwá suumé mimbira umbaú kapĩ turusú?

49 - - Pourquoi?

49 - - Marã taá?

50 - - Parce que chez moi c'est tout petit...

50 - - Nhaãsé mamé amurari panhẽ maã mirĩ...

51 - - Ça suffira sûrement. Je t'ai donné un tout petit mouton.”

51 - - Kapĩ mirĩ uikú ana puranga. Ameẽ indé arã yepé suumé mimbira mirĩ retana.

52 - Il pencha la tête vers le dessin:

52 - Umuyawika i akanga kwatiarisawa resé.

53 - "Pas si petit que ça... Tiens! Il s'est endormi..."

53 - - Aé ti tẽ kwaíra retana... Remaã! Ukiri ana...

54 - Et c'est ainsi que je fis la connaissance du petit prince.

54 - Kwayé akwáu nhaã muruxawamirĩ. 


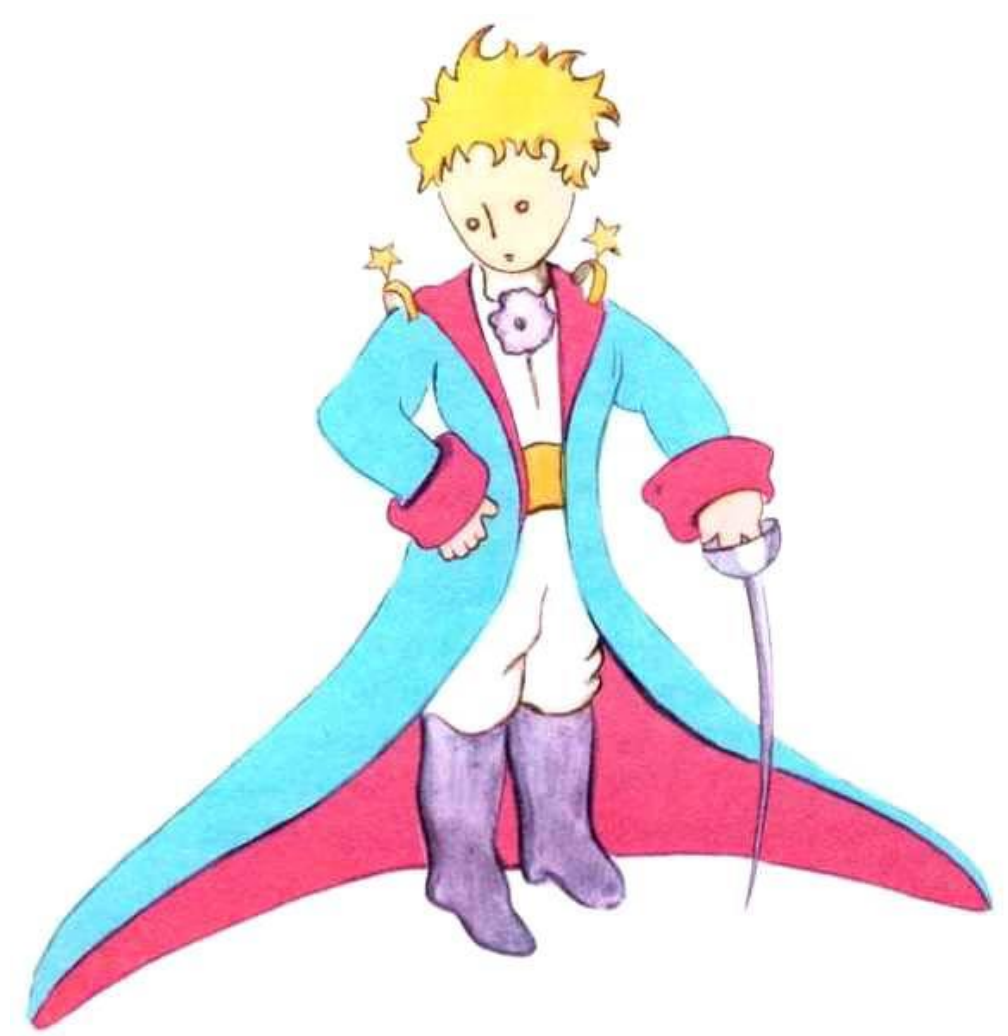

Voilà le meilleur portrait que, plus tard, j’ai réussi à faire de lui.

Xukúi sangawa puranga piri amunhã-kwáu waá sesé asuiwara.

1 - Il me fallut longtemps pour comprendre d'où il venait.

1 - Aikupukú retana akwáu arama masuí nhaã muruxawamirĩ uri.

2 - Le petit prince, qui me posait beaucoup de questions, ne semblait jamais entendre les miennes.

2 - Muruxawamirĩ, upurandú waá kwera siía maã se suí, nẽ mairamé usendú maã apurandú i suí.

3 - Ce sont des mots prononcés par hasard qui, peu à peu, m’ont tout révélé.

3 - Aramé yepé-yepé nheenga unheẽ waá, merupí tá umukameẽ pawa ixé arama.

4 - Ainsi, quand il aperçut pour la première fois mon avion (je ne dessinerai pas mon avion, c'est un dessin beaucoup trop compliqué pour moi) il me demanda:

4 - Yawé, mairamé umaã, yepesawa í, se pepusantá (ti akwatiari kurí se pepusantá, kwá yepé sangawa iwasú retana ixé arama), aé upurandú se suí: 
5 - “Qu'est-ce que c'est que cette chose-lá?

5 - - Maã taá nhaã maã mimi?

6 - - Ce n'est pas une chose. Ça vole. C'est un avion. C'est mon avion.”

6 - - Nhaã ti yepé maã. Nhaã uwewé. Nhaã yepé pepusantá. Se pepusantá.

7 - Et j'étais fier de lui apprendre que je volais. Alors il s'écria:

7 - Se rurí apitá mairamé ambeú i xupé awewewera. Aramé, i akanhemu xinga, upurandú se suí:

8 - “Comment! tu es tombé du ciel!

8 - - Maã taá? Rewari iwaka suí?

9 - - Oui, fis-je modestement.

9 - - Eẽ - anheẽ-ntu nhaã.

10 - - Ah! ça c'est drôle!...”

10 - - Ah! Kwá amurupí retana!

11 - Et le petit prince eut un très joli éclat de rire qui m'irrita beaucoup.

11 - Aramé muruxawamirĩ sé upuká, sesewara se piaíwa retana.

12 - Je désire que l'on prenne mes malheurs au sérieux. Puis il ajouta:

12 - Ti aputari mira-itá umusarai se purarasawa irumu. Asuí, aé umuapiri:

13 - "Alors, toi aussi tu viens du ciel! De quelle planète es-tu?"

13 - - Aramé, indé yuíri reyuri iwaka suí! Maã iwaka-retama suí indé reyuri?

14 - J'entrevis aussitôt une lueur, dans le mystère de sa présence, et j'interrogeai brusquement:

14 - Aramé tẽ ayupirũ amaã masuí uri nhaã muruxawamirĩ, asuí apurandú i suí:

15 - “Tu viens donc d'une autre planète?"

15 - - Reyuri yepé tetama suí ti waá upitá Iwí upé?

16 - Mais il ne me répondit pas. Il hochait la tête doucement tout en regardant mon avion:

16 - Ma aé ti usuaxara. Umuyatimú merupí i akanga umaã pukusawa se pepusantá:

17 - "C'est vrai que, là-dessus, tu ne peux pas venir de bien loin...”

17 - - Kwá irumu, supí, ti reyuri-kwáu tẽ apekatú retana suí... 
18 - Et il s'enfonça dans une rêverie qui dura longtemps.

18 - Aramé uyapumi yepé manduarisawa upé uikupukú retana waá.

19 - Puis, sortant mon mouton de sa poche, il se plongea dans la contemplation de son trésor.

19 - Upisika amú í nhaã sangawa asuí umaã-maã nhaã suumirĩ puranga resé.

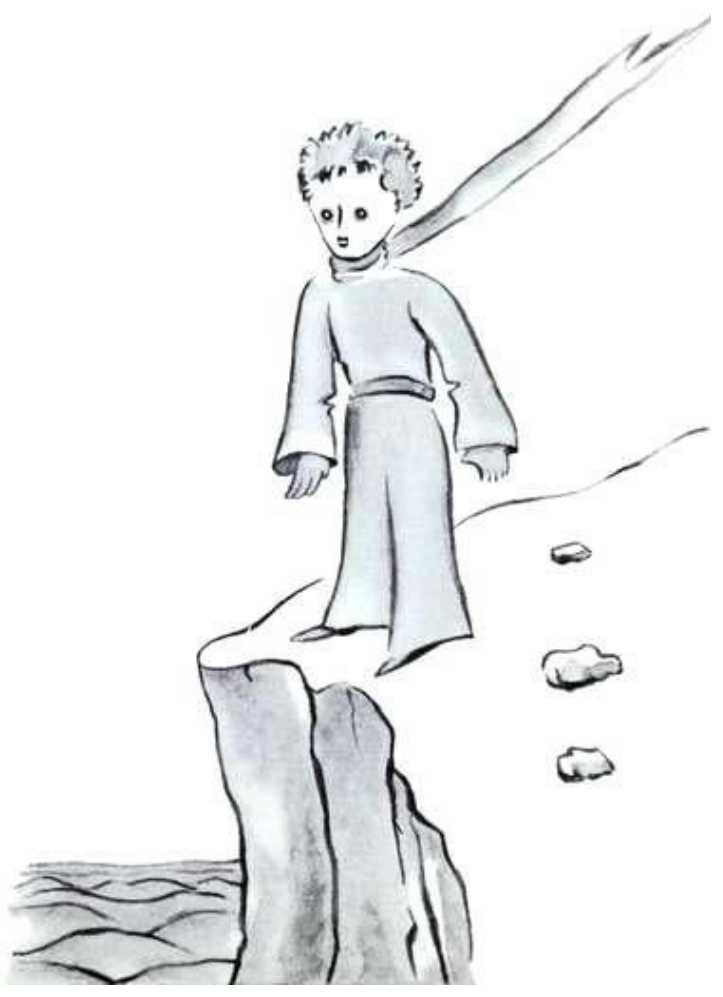

20 - Vous imaginez combien j'avais pu être intrigué par cette demi-confidence sur "les autres planètes".

20 - Pemanduari mayé se akanhemu asendú resewara amú awá upurungitá tetama-itá resé ti waá-itá upitá Iwí upé.

21 - Je m'efforçai donc d'en savoir plus long:

21 - Aramé akwáu-putari piri xinga sesewara:

22 - "D'où viens-tu, mon petit bonhomme? Où est-ce "chez toi"? Où veux-tu emporter mon mouton?"

22 - - Masuí taá reyuri, apigawamirĩ? Mamé taá ne ruka? Makití taá rerasúputari kwá suumé mimbira?

23 - Il me répondit après un silence méditatif:

23 - Usuaxara ixé arama umanduari xinga riré: 
24 - “Ce qui est bien, avec la caisse que tu m'as donnée, c'est que, la nuit, ça lui servira de maison.

24 - - Patuá remeẽ waá ixé arã, aé kurí yepé uka nungara i xupé pituna ramé.

25 - - Bien sûr. Et si tu es gentil, je te donnerai aussi une corde pour l'attacher pendant le jour. Et un piquet."

25 - - Supí. Ne katú ramé kurí se irumu, ameẽ kurí indé arã yepé tupasama repukwari arã aé ara pukusawa asuí yepé mirá pisãwéra upitasuka arã aé.

26 - La proposition parut choquer le petit prince:

26 - Maã anheẽ waá umuakanhemu pu muruxawamirĩ:

27 - “L'attacher? Quelle drôle d'idée!

27 - - Apukwari arã aé? Kwá yepé akangaiwasawa!

28 - - Mais si tu ne l'attaches pas, il ira n'importe où, et il se perdra."

28 - - Ma ti ramé repukwari aé, usú kurí amú tendawa kití asuí uyusupari.

29 - Et mon ami eut un nouvel éclat de rire:

29 - Aramé se rumuara uyupirũ upuká amú í:

30 - "Mais où veux-tu qu'il aille!

30 - - Ma... makití taá remaité aé usú?

31 - - N'importe où. Droit devant lui..."

31 - - Ti akwáu marupí. Senundé kití tẽ...

32 - Alors le petit prince remarqua gravement:

32 - Aramé muruxawamirĩ unheẽ santá:

33 - "Ça ne fait rien, c'est tellement petit, chez moi!"

33 - - Puranga pá, mamé amurari panhẽ maã mirĩ retana!

34 - Et, avec un peu de mélancolie, peut-être, il ajouta:

34 - Asuí, araneíma sasiara xinga, aé unheẽ rẽ:

35 - "Droit devant soi on ne peut pas aller bien loin..."

35 - - Mairamé yawatawara yané renundé kití, ti tẽ yasú-kwáu apekatú retana... 


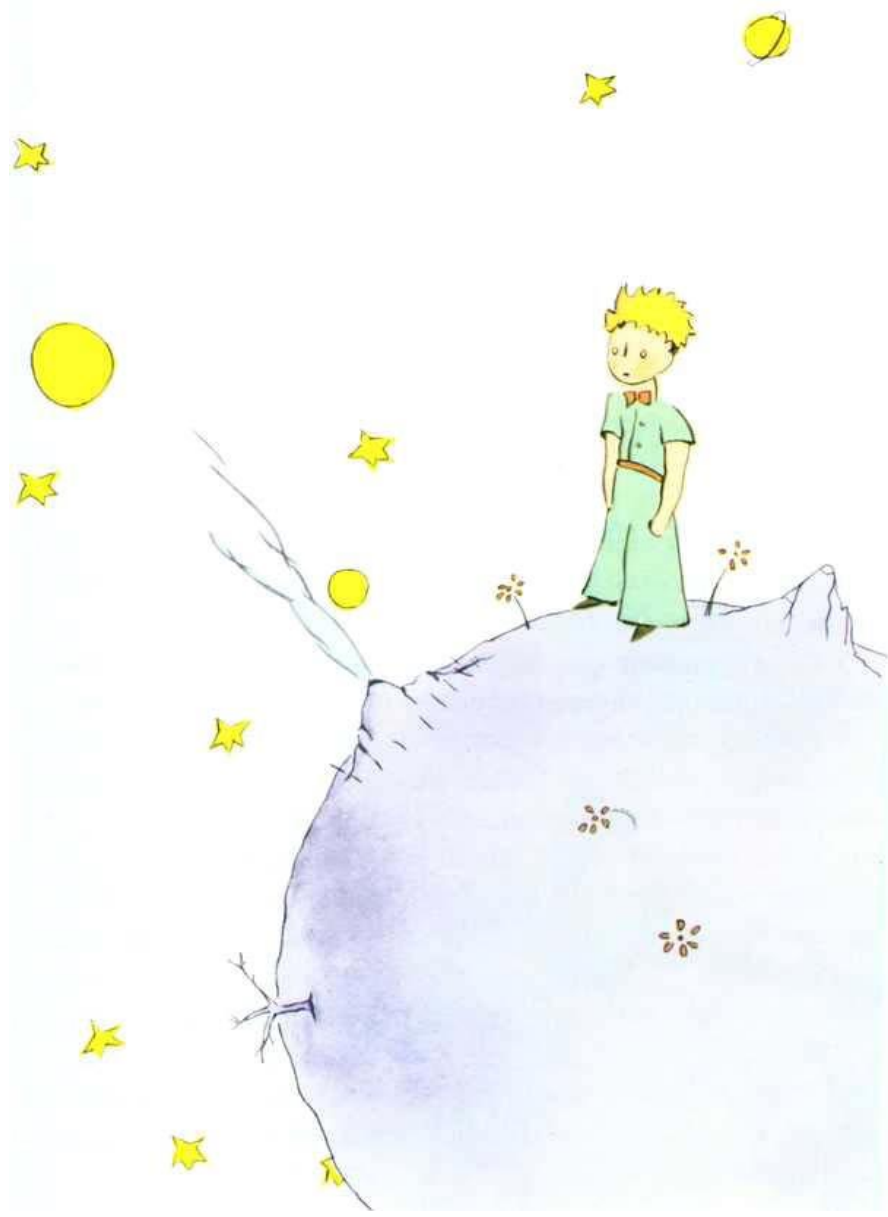

Le petit prince sur l'astéroïde B 612.

Muruxawamirĩ iwaka-retama B 612 resé.

1 - J'avais ainsi appris une seconde chose très importante: c'est que sa planète d'origine était à peine plus grande qu'une maison!

1 - Asuí ayumbué amú maã sesewara: iwaka-retama masuí muruxawamirĩ uri, aé kwera turusú piri xinga yepé uka suí!

2 - Ça ne pouvait pas m'étonner beaucoup.

\section{2 - Ma kwá ti umuakanhemu ixé.}

3 - Je savais bien qu'en dehors des grosses planètes comme la Terre, Jupiter, Mars, Vénus, auxquelles on a donné des noms, il y a en a des centaines d'autres qui sont quelquefois si petites qu'on a beaucoup de mal à les apercevoir au télescope.

3 - Akwáu ti aikwé anhũ iwaka-retama turusú mayé Iwí, Yupiteri, Máriti u Wénusi yawé, tá urikú ana waá aintá rera, ma aikwé yuíri amú-itá, kwaíra retana, ti waá-itá yamaã-kwáu nẽ yasitatá-maãsára irumu. 
4 - Quand un astronome découvre l'une d'elles, il lui donne pour nom un numéro. Il l'appelle par exemple: "l'astéroïde 325".

4 - Mairamé yepé yasitatá-sikarisara uwasemu yepé aintá suiwara, useruka aé yepé paparisawa rupí. Yawé kwá iwaka-retama uyuseruka-kwáu "iwaka-retama 325".

5 - J'ai de sérieuses raisons de croire que la planète d'où venait le petit prince est l'astéroïde B 612.

5 - Aruyari tẽ muruxawamirĩ uri yepé tetama suí sera waá “iwaka-retama B 612”.

6 - Cet astéroïde n'a été aperçu qu'une fois au télescope, en 1909, par un astronome turc.

6 - 1909 ramé, yepé yasitatá-sikarisara Turquiawara umaã kwá iwaka-retama yepé yasitatá-maãsára pupé.

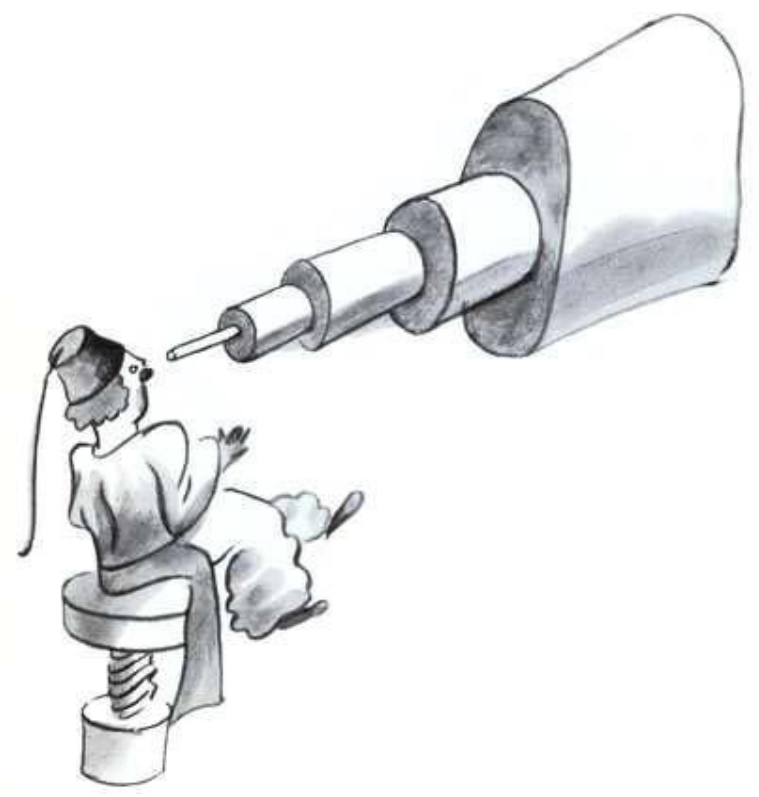

7 - Il avait fait alors une grande démonstration de sa découverte à un congrès internacional d'astronomie.

7 - Nhã̃ akayú ramé, aé umukameẽ i wasemusawa yepé wayurí upé yasitatásikarisara-itá irumu Iwí retama riía suiwara.

8 - Mais personne ne l'avait cru à cause de son costume. Les grandes personnes sont comme ça.

8 - Ma nẽ awá uruyari sesé i muamundewa resewara. Mira-itá turusú tá yawé tẽ. 

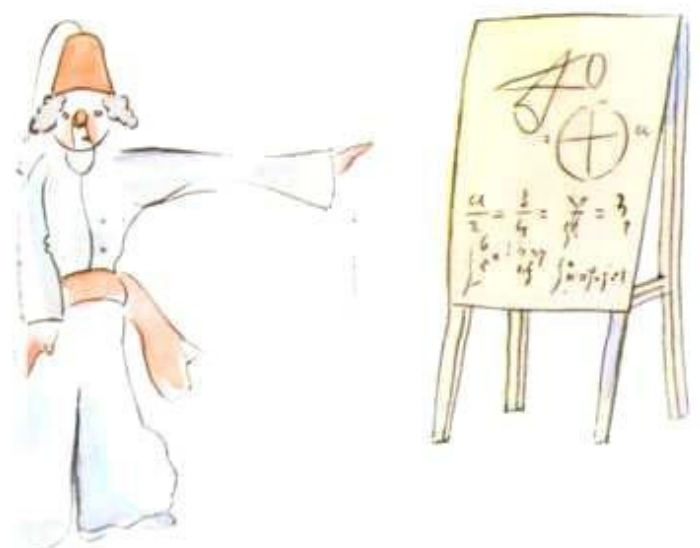

9 - Heureusement pour la réputation de l'astéroïde B 612, un dictateur turc imposa à son peuple, sous peine de mort, de s'habiller à l'européenne.

9 - Ma tá uyupirũ uruyari iwaka-retama B 612 wasemusawa resé mairamé yepé muruxawa puxí retana Turquiawara umundú setamawara-itá umuamundéu mayé Europawara-itá yawé.

10 - L'astronome refit sa démonstration en 1920, dans un habit très élégant. Et cette fois-ci tout le monde fut de son avis.

10 - Yasitatá-sikarisara umukameẽ i wasemusawa, amú í, 1920 ramé. Aramé, mayé umundéu uikú yepé muamundewa puranga retana, tá uruyari sesé.
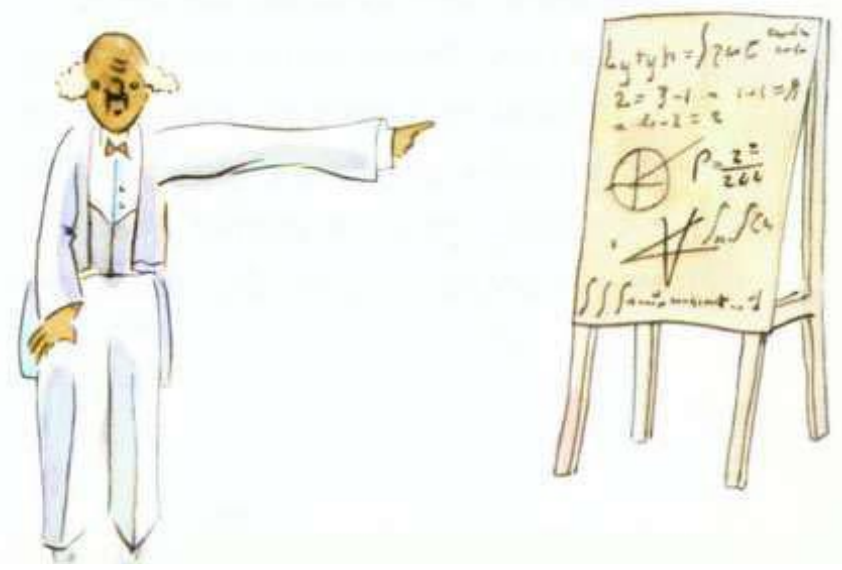

11 - Si je vous ai raconté ces détails sur l'astéroïde B 612 et si je vous ai confié son numéro, c'est à cause des grandes personnes.

11 - Ambeú ramé penhẽ arama siía maã iwaka-retama B 612 resewara, mayé i paparisawa, yawé amunhã mira-itá turusú resewara.

12 - Les grandes personnes aiment les chiffres.

12 - Mira-itá turusú usaisú paparisawa-itá. 
13 - Quand vous leur parlez d'un nouvel ami, elles ne vous questionnent jamais sur l'essentiel.

13 - Mairamé yapurungitá yané rumuara pisasú resé, aintá ti upurandú nẽ mairamé sesewara tẽ.

14 - Elles ne vous disent jamais: “Quel est le son de sa voix? Quels sont les jeux qu'il préfère? Est-ce qu'il collectionne les papillons?”

14 - Aintá ti upurandú nẽ mairamé: "Mayé taá i nheenga? Mayewa musaraisawa umusurí piri waá aé? Umuatiri será panapanã-itá?"

15 - Elles vous demandent: "Quel âge a-t-il? Combien a-t-il de frères? Combien pèse-til? Combien gagne son père?"

15 - Ma tá upurandú: "Muíri akayú aé urikú? Muíri mũ aé urikú? Muíri i pusesawa urikú? Muíri real i paya upisika?"

16 - Alors seulement elles croient le connaître.

16 - Aramé, yawé-ntu tá uruyari tá ukwáu aé.

17 - Si vous dites aux grandes personnes: "J'ai vu une belle maison en briques roses, avec des géraniums aux fenêtres et des colombes sur le toit...", elles ne parviennent pas à s'imaginer cette maison.

17 - Yanheẽ ramé mira-itá turusú supé: "Amaã yepé uka piranga puranga retana, putira-itá irumu ukenaĩ upé asuí pikasú-itá uka-pupekasara upé...", aintá ti umanduari-kwáu kwá uka rangawa.

18 - Il faut leur dire: "J'ai vu une maison de cent mille francs."

18 - Uwatari rẽ yanheẽ aintá supé: “Amaã yepé uka sepiasú retana.”

19 - Alors elles s'écrient: “Comme c'est joli!"

19 - Aramé aintá unheẽ: "Kwá uka puranga tẽe"

20 - Ainsi, si vous leur dites, 'La preuve que le petit prince a existé c'est qu'il était ravissant, qu'il riait, et qu'il voulait un mouton. Quand on veut un mouton, c'est la preuve qu'on existe", elles hausseront les épaules et vous traiteront d'enfant!

20 - Yawé, yanheẽ ramé aintá supé: "Muruxawamirĩ ti yepé marandua nhaãsé aé puranga retana, aé upuká asuí uputari yepé suumé mimbira. Awá-ntu sikwé uputari-kwáu yepé suumé mimbira", aintá ti uruyari kurí yané resé asuí tá unheẽ kurí yandé mayé taína-itá yawé!

21 - Mais si vous leur dites: "La planète d'où il venait est l'astéroïde B 612", alors elles seront convaincues, et elles vous laisseront tranquille avec leurs questions. 
21 - Ma yanheẽ ramé : “Tetama masuí aé uri iwaka-retama B 612", aramé aintá uruyari kurí asuí ti kurí tá umunhã amú-itá purandusawa.

22 - Elles sont comme ça. Il ne faut pas leur en vouloir.

22 - Yawé tẽ aintá. I katú rẽ ti yaxari yasaisú aintá sesewara.

23 - Les enfants doivent être très indulgents envers les grandes personnes.

23 - Taína-itá urikuté tá susanga retana mira-itá turusú irumu.

24 - Mais, bien sûr, nous qui comprenons la vie, nous nous moquons bien des números!

24 - Ma yandé arama, yakwáu puranga waá mayé kwá sikwesawa, paparisawa-itá ti tẽ maã-itá supiwara!

25 - J'aurais aimé commencer cette histoire à la façon de contes de fées. J'aurais aimé dire: "Il était une fois un petit prince qui habitait une planète à peine plus grande que lui, et qui avait besoin d'un ami..."

25 - Aputari maã ayupirũ kwá papera mayé marandua-itá kuxiimawara yawé. Aputari maã ayupirũ aé kwayé: "Aikwé, paá, yepé muruxawamirĩ umurari waá yepé iwaka-retama upé turusú piri xinga i suí, awá supé uwatari rẽ yepé sumuara..."

26 - Pour ceux qui comprennent la vie, ça aurait eu l'air beaucoup plus vrai.

26 - Mira-itá supé ukwáu waá-itá sikwesawa purangasawa, araneíma kwá supiwara piri.

27 - Car je n'aime pas qu'on lise mon livre à la légère.

27 - Ti asaisú tá umaã ara rupí se papera.

28 - J'éprouve tant de chagrin à raconter ces souvenirs.

28 - Sasiara retana apitá mairamé ambeú kwá manduarisawa-itá.

29 - Il y a six ans déjà que mon ami s'en est allé avec son mouton.

29 - Aikwé ana puyepé akayú se rumuara usú ana se suí i suumé mimbira irumu.

30 - Si j'essaie ici de le décrire, c'est afin de ne pas oublier.

30 - Ambeú sesewara kwá papera upé nhaãsé ti aputari se resarái i suí.

31 - C'est triste d'oublier un ami.

31 - Sasiara retana yané resarái yané rumuara suí.

32 - Tout le monde n'a pas eu un ami. 
32 - Nẽ panhẽ awá urikú yepé sumuara.

33 - Et je puis devenir comme les grandes personnes qui ne s'intéressent plus qu'aux chiffres.

33 - Araneíma ayeréu yepé mira turusú mayé amú-itá yawé, upurungitá-ntu waáitá paparisawa resewara.

34 - C'est donc pour ça encore que j'ai acheté une boîte de couleurs et des crayons.

34 - Sesewara tẽ apiripana yepé pinimasara rupiara riía.

35 - C'est dur de se remettre au dessin, à mon âge, quand on n'a jamais fait d'autres tentatives que celle d'un boa fermé et celle d'un boa ouvert, à l'âge de six ans!

35 - Iwasú ixé arama ayuíri akwatiari uií ara ramé, nhaãsé, mairamé arikú puyepé akayú, ayumbué-ntu akwatiari buyawasú rangawa-itá!

36 - J'essaierai, bien sûr, de faire des portraits le plus ressemblants possible.

36 - Asikari kurí amunhã sangawa-itá puranga piri akwáu waá-itá.

37 - Mais je ne suis pas tout à fait certain de réussir.

37 - Ma ti tẽ akwáu sa akwáu kurí.

38 - Un dessin va, et l'autre ne ressemble plus.

38 - Yepé kwatiarisawa usemu pu puranga, ma amú-itá usemu ana amurupí.

39 - Je me trompe un peu aussi sur la taille.

39 - Ixé yuíri ayuganani xinga sangawa turususawa resewara.

40 - Ici le petit prince est trop grand. Là il est trop petit.

40 - Amuramé muruxawamirĩ usemu turusú retana, amuramé kwaíra retana.

41 - J'hésite aussi sur la couleur de son costume.

41 - Ti amanduari puranga retana i muamundewa pinimasawa resé.

42 - Alors je tâtonne comme ci et comme ça, tant bien que mal.

42 - Aramé amunhã siía kwatiarisawa, yepé-yepé puranga, umú-itá puxiwera.

43 - Je me tromperai enfin sur certains détails plus importants. Mais ça, il faudra me le pardonner.

43 - Se resarái kurí rẽ siía maã suí, ma ayururéu pe suí peyerũ arama ixé. 
44 - Mon ami ne donnait jamais d'explications.

44 - Se rumuara nẽ mairamé umusakakanga amu-itá nheenga irumu maã aé unheẽ waá.

45 - Il me croyait peut-être semblable à lui.

45 - Araneíma aé umaité ixé mayé i yawé.

46 - Mais moi, malheureusement, je ne sais pas voir les moutons à travers les caisses.

46 - Ma ixé amurupí i suí, ti amaã-kwáu suumé mimbira patuá pitera rupí.

47 - Je suis peut-être un peu comme les grandes personnes. J'ai dû vieillir.

47 - Araneíma ixé xinga mayé mira-itá turusú yawé. Tuyué apitá pu aikú.

1 - Chaque jour j'apprenais quelque chose sur la planète, sur le départ, sur le voyage.

1 - Muíri ara ayumbué manungara tetama resewara masuí aé uri asuí i watasawa resewara.

2 - Ça venait tout doucement, au hasard des réflexions.

2 - Ma kwá usika merupí, maã-itá rupí upurungitá waá kwera se irumu.

3 -C'est ainsi que, le troisième jour, je connus le drame de baobabs.

3 - Kwayé, musapirisawa ara ramé, akwáu baobá-itá resewara.

4 - Cette fois-ci encore ce fut grâce au mouton, car brusquement le petit prince m'interrogea, comme pris d'un doute grave:

4 - Akwáu baoba-itá resewara suumé mimbira resewara, mairamé muruxawamirĩ upurandú se suí:

5 - “C'est bien vrai, n'est-ce pas, que les moutons mangent les arbustes?

5 - - Supisawa será suumé mimbira-itá umbaú yaitiwa?

6 - - Oui. C'est vrai.

6 - - Eẽ. Supí.

7 - - Ah! Je suis content!"

7 - - Ah! Ixé se rurí! 
8 - Je ne compris pas pourquoi il était si important que les moutons mangeassent les arbustes.

8 - Ti akwáu nhaãsé puranga tẽ suumé mimbira-itá umbaú maã yaitiwa.

9 - Mais le petit prince ajouta:

9 - Ma muruxawamirĩ umuapiri:

10 - "Par conséquent ils mangent aussi les baobabs?"

10 - - Yawé tá umbaú baobá-itá yuíri?

11 - Je fis remarquer au petit prince que les baobabs ne sont pas des arbustes, mais des arbres grands comme des églises et que, si même il emportait avec lui tout un troupeau d'éléphants, ce troupeau ne viendrait pas à bout d'un seul baobab.

11 - Anheẽ muruxawamirĩ supé baobá amurupí yaitiwa suí, yepé baobá mirá turusú mayé yepé tupauku yawé, asuí aé urasú ramé tẽ maã yepé erepanti riía i irumu, aintá ti uitika-kwáu maã nẽ yepé baobá.

12 - L’idée du troupeau d'éléphants fit rire le petit prince:

12 - Manduarisawa yepé erepanti riía resewara umupuká muruxawamirĩ:

13 - "Il faudrait les mettre les uns sur les autres..."

13 - - Arikuté maã amburi aintá yepé amú árupi...

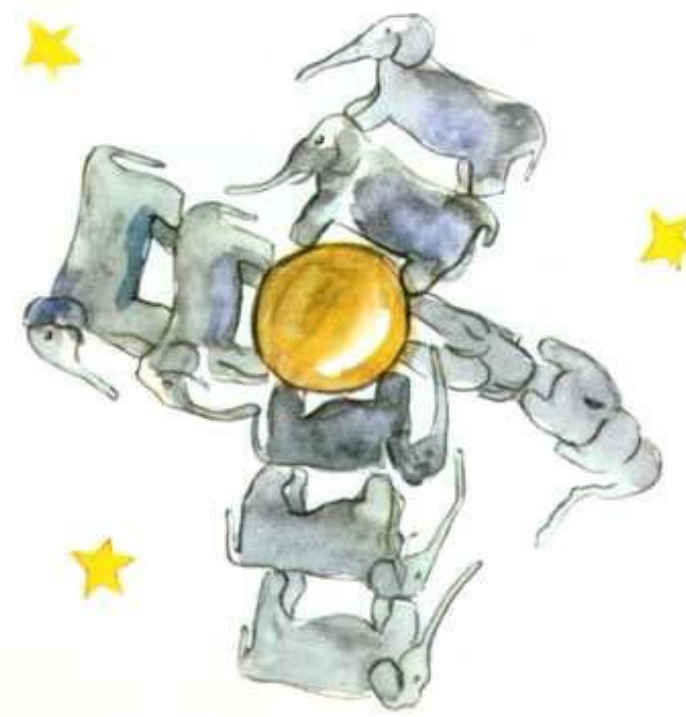

14 - Mais il remarqua avec sagesse:

14 - Ma, kwausawa irumu, unheẽ:

15 - "Les baobabs, avant de grandir, ça commence par être petit. 
15 - - Baobá-itá uyumunhã renundé, aintá kwaíra.

16 - - C'est exact! Mais pourquoi veux-tu que tes moutons mangent les petits baobabs?"

16 - - Supí! Ma, marã taá indé reputari ne suumé mimbira umbaú baobá kwaíra waá-itá?

17 - Il me répondit: “Ben! Voyons!”, comme s’il s’agissait là d'une évidence.

17 - Aé usuaxara: "Remaã katu!”, mayé unheẽ ramé maã manungara sakakanga retana.

18 - Et il me fallut un grand effort d'intelligence pour comprendre à moi seul ce problème.

18 - Arikuté amanduari katú akwáu arama maã aé unheẽ-putari uikú waá.

19 - Et en effet, sur la planète du petit prince, il y avait, comme sur toutes les planètes, de bonnes herbes et de mauvaises herbes.

19 - Supí, aikwé muruxawamirĩ retama upé, mayé panhẽ iwaka-retama upé yawé, íwa-itá puranga, íwa-itá puxí.

20 - Par conséquent de bonnes graines de bonnes herbes et de mauvaises graines de mauvaises herbes.

20 - Yawé, aikwé tainha-itá puranga íwa-itá puranga suiwara asuí tainha-itá puxí íwa-itá puxí suiwara.

21 - Mais les graines sont invisibles.

21 - Ma ti yamaã-kwáu tainha-itá.

22 - Elles dorment dans le secret de la terre jusqu'à ce qu'il prenne fantaisie à l'une d'elles de se réveiller.

22 - Aintá ukiri iwí marika upé té ara mairamé yepé aintá suiwara uparawaka upaka asuí usemu.

23 - Alors elle s'étire, et pousse d'abord timidement vers le soleil une ravissante petite brindille inoffensive.

23 - Aramé, upaka riré, aé usú usemu merupí asuí umukameẽ kurasí supé yepé puranga sakangamirĩ.

24 - S'il s'agit d'une brindille de radis ou de rosier, on peut la laisser pousser comme elle veut.

24 - Kwá sakangamirĩ ramé íwa puranga suiwara, yaxari-kwáu aé usemu asuí uyumunhã. 
25 - Mais s'il s'agit d'une mauvaise plante, il faut arracher la plante aussitôt, dès qu'on a su la reconnaître.

25 - Ma yepé íwa puxí ramé, yarikuté yayuka mairamé yamaã aé.

26 - Or il y avait des graines terribles sur la planète du petit prince... c'étaient les graines de baobabs.

26 - Aikwé tainha-itá puxí retana muruxawamirĩ retama upé... baobá rainha-itá.

27 - Le sol de la planète en était infesté.

27 - Setama iwí teresemu uikú tá irumu.

28 - Or un baobab, si l'on s'y prend trop tard, on ne peut jamais plus s'en débarrasser.

28 - Ti ramé yamaã kutara nungara nhaã íwamirĩ yepé baobá, ti yayuka-kwáu aé asuiwara.

29 - Il encombre toute la planète. Il la perfore de ses racines.

29 - Aé upupeka tetama pawa, asuí sapú-itá umukwara iwí.

30 - Et si la planète est trop petit, et si les baobabs sont trop nombreux, ils la font éclater.

30 - Yepé tetama ramé kwaíra retana ma aikwé siía baobá sesé, aé upuka pawa.

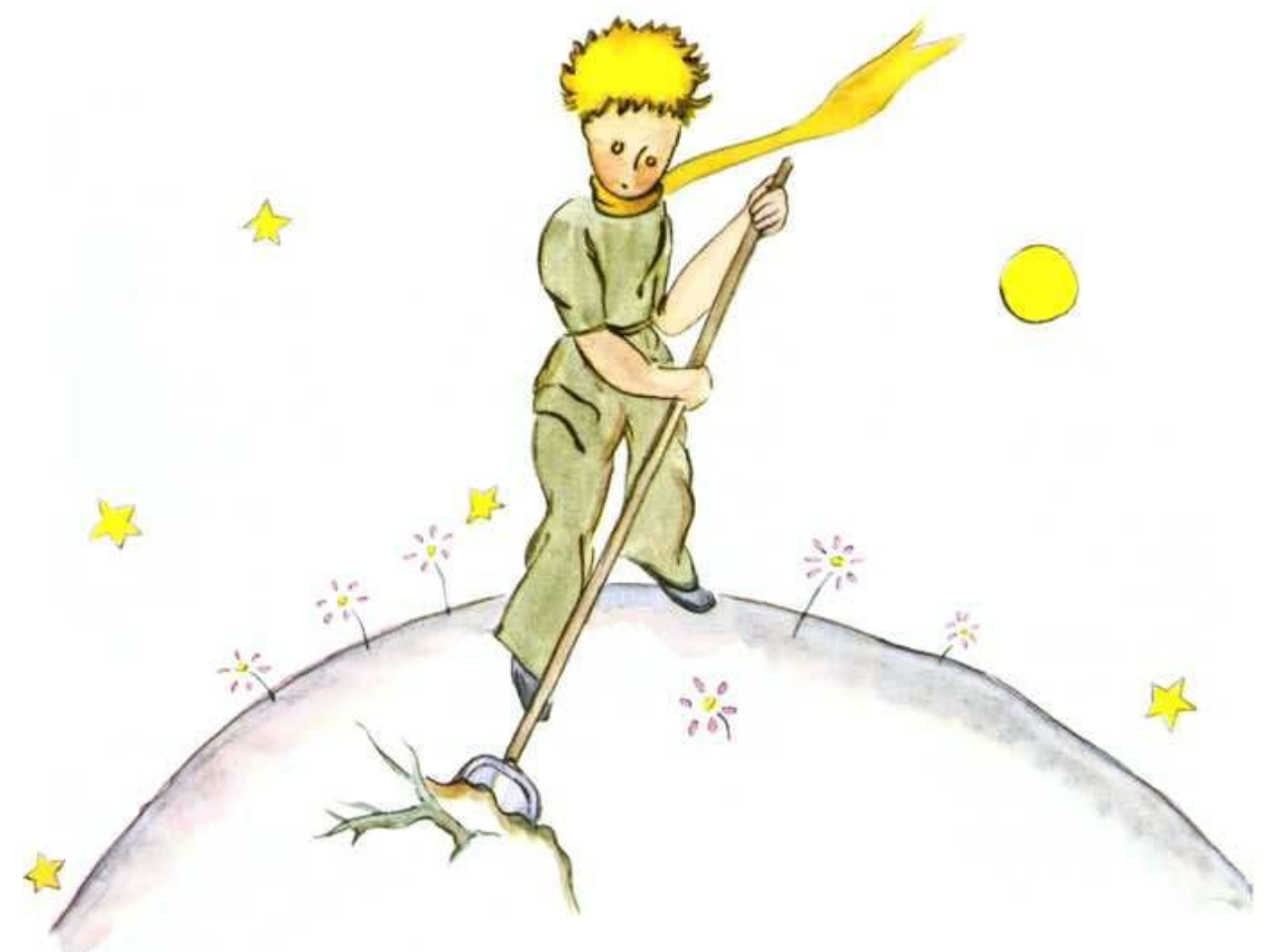


31 - “C'est une question de discipline, me disait plus tard le petit prince.

31 - "Yarikuté yamanhana yaikú", muruxawamirĩ unheẽ ixé arama.

32 - Quand on a terminé sa toilette du matin, il faut faire soigneusement la toilette de la planète.

32 - "Mairamé yapawa yayuyusí kwema ramé, yarikuté yamunhã tetama yusisawa".

33 - Il faut s'astreindre régulièrement à arracher les baobabs dès qu'on les distingue d'avec les rosiers auxquels ils ressemblent beaucoup quand ils sont très jeunes.

33 - Yarikuté yayuka baobá-itá panhẽ mairamé yamaã-kwáu aintá amurupí íwaitá puranga suí, nhaãsé baobá pisasú mayé íwa puranga yawé.

34 - C'est un travail très ennuyeux, mais très facile."

34 - Kwá yepé murakí maraariwera retana, ma ti iwasú.

35 - Et un jour il me conseilla de m'appliquer à réussir un beau dessin, pour bien faire entrer ça dans la tête des enfants de chez moi.

35 - Yepé ara, aé umungitá ixé amunhã arama yepé kwatiarisawa puranga, amukameẽ arama baobá-itá yawaitesawa taína-itá se retamawara supé.

36 - "S’ils voyagent un jour, me disait-il, ça pourra leur servir.

36 - "Yepé ara, tá uwatá ramé”, unheẽ ixé arama, "kwá kurí puranga aintá supé.

37 - Il est quelquefois sans inconvénient de remettre à plus tard son travail.

37 - Amuramé yaikupukú-kwáu yapawa arama yepé murakí.

38 - Mais, s'il s'agit des baobabs, c'est toujours une catastrophe.

38 - Ma baobá-itá resewara panhẽ mairamé yepé yawaitesawa turusú retana.

39 - J'ai connu une planète, habitée par un paresseux. Il avait négligé trois arbustes..."

39 - Akwáu yepé iwaka-retama mamé umurari yepé apigawa yatimamanha. Ape, aé uxari uyumunhã musapiri yaitiwa..."

40 - Et, sur les indications du petit prince, j'ai dessiné cette planète-là.

40 - Aramé, muruxawamirĩ nheenga-itá rupí, ixé akwatiari-kwáu nhaã iwakaretama.

41 - Je n'aime guère prendre le ton d'un moraliste.

41 - Ti aputari tá uwasemu ixé yepé mira mungitasara. 
42 - Mais le danger des baobabs est si peu connu, et les risques courus par celui qui s'égarerait dans un astéroïde sont si considérables, que, pour une fois, je fais exception à ma réserve.

42 - Ma, mayé kwaíra mira-itá ukwáu baobá-itá yawaitesawa mairamé amú awá uyusupari uikú yepé tetama upé mamé aikwé siía mirá kwayé, anheẽ penhẽ arama:

43 - Je dis: "Enfants! Faites attention aux baobabs!"

43 - "Taína-itá, pemaã katú baobá-itá resé!"

44 - C'est pour avertir mes amis d'un danger qu'ils frôlaient depuis longtemps, comme moi-même, sans le connaître, que j'ai tant travaillé ce dessin-là.

44 - Aikupukú retana apawa arama nhaã kwatiarisawa nhaãsé amukameẽ-putari puranga retana se rumuara-itá supé yawaitesawa-itá yasasá waá baobá-itá resewara.

45 - La leçon que je donnais en valait la peine.

45 - Se mbuesawa upitimũ-kwáu aintá.

46 - Vous vous demanderez peut-être: Pourquoi n'y a-t-il pas, dans ce livre, d'autres dessins aussi grandioses que le dessin des baobabs?

46 - Araneíma pepurandú kurí: "Marã taá ti yamaã, kwá papera upé, amú kwatiarisawa puranga mayé baobá-itá kwatiarisawa yawé?"

47 - La réponse est bien simple: J'ai essayé mais je n'ai pas pu réussir.

47 - Se suaxarasawa yawé-ntu: Ixé akwatiari-putari, ma aé ti upitá puranga.

48 - Quand j'ai dessiné les baobabs j'ai été animé par le sentiment de l'urgence.

48 - Mairamé akwatiari baobá-itá, ixé amanduari aikú-ntu yawaitesawa resé aintá resewara. 


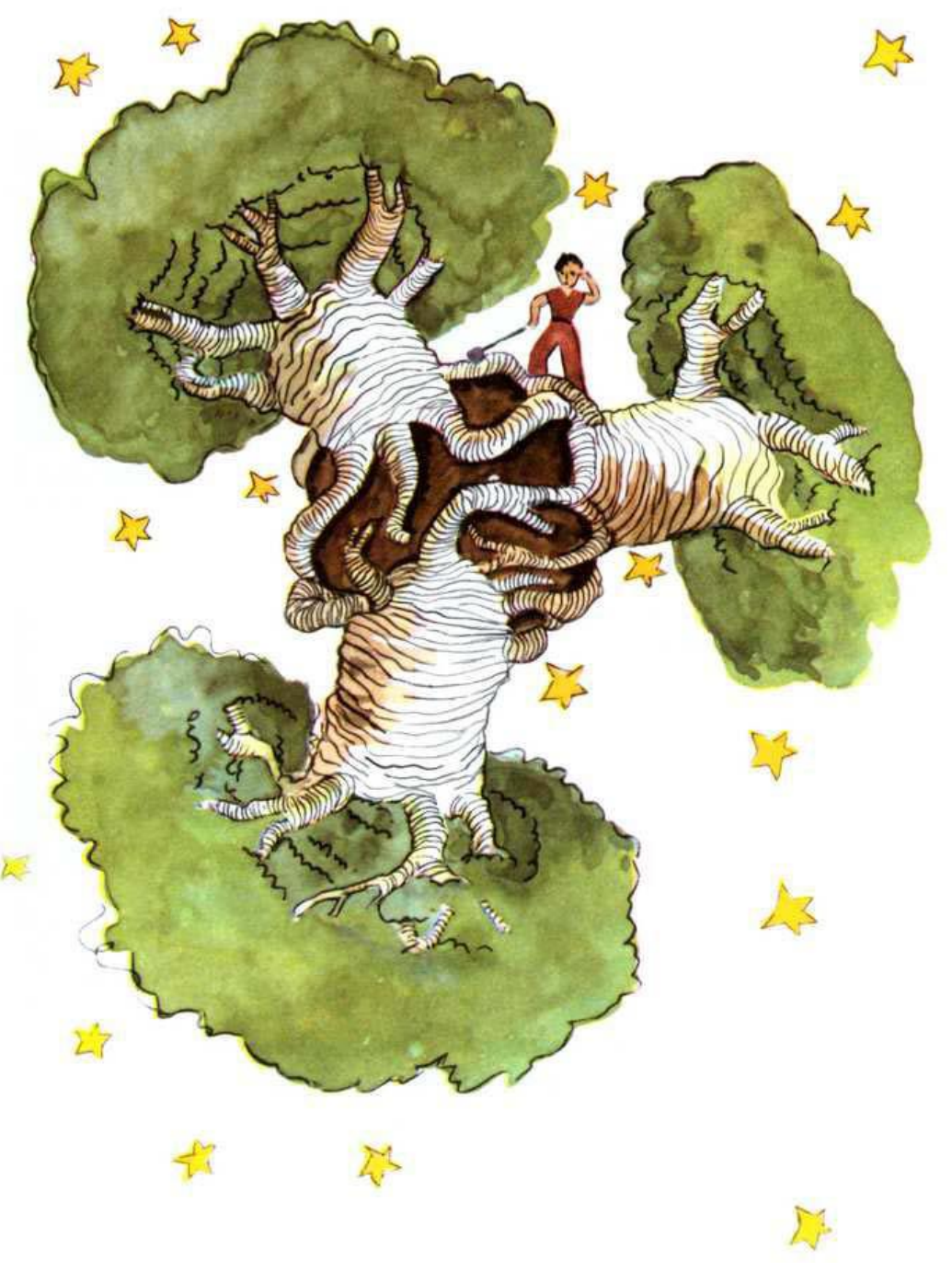

Les baobabs.

Baobá-itá.

6

1 - Ah! petit prince, j’ai compris, peu à peu, ainsi, ta petite vie mélancolique.

1 - Ah!, muruxawamirĩ, ariré ayupirũ amaã puranga piri xinga ne rikwesawa sasiara resewara.

2 - Tu n'avais eu longtemps pour distraction que la douceur des couchers de soleil.

2 - Siía ara pukusawa, repitá-ntu ne rurí kurasí wapikasawa-itá purangasawa irumu.

3 - J'ai appris ce détail nouveau, le quatrième jour au matin, quand tu m'as dit:

4 - Akwáu sesewara, ara irundisawa kwema ramé, mairamé renheẽ ixé arama: 
5 - "J'aime bien les couchers de soleil. Allons voir un coucher de soleil...

5 - - Ixé asaisú amaã kurasí wapikasawa. Yasú yamaã yepé kurasí wapikasawa...

6 - - Mais il faut attendre...

6 - - Ma yarikuté yasarú...

7 - - Attendre quoi?

7 - - Maã taá yarikuté yasarú?

8 - - Attendre que le soleil se couche."

8 - - Yarikuté yasarú kurasí uwapika.

9 - Tu as eu l'air très surpris d'abord, et puis tu as ri de toi-même. Et tu m'as dit:

9 - Ne akanhemu retana yupirungawa ramé, ma asuí reyupirũ repuká ne resé tẽ. Aramé, renheẽ ixé arama:

10 - "Je me crois toujours chez moi!"

10 - - Amaité, muíri tendawa upé, aikú se retama upé.

11 - En effet. Quand il est midi aux États-Unis, le soleil, tout le monde le sait, se couche sur la France.

11 - Supí, mairamé yandara Estados Unidos upé, panhẽ awá ukwáu, kurasí uwapika França árupi.

12 - Il suffirait de pouvoir aller en France en une minute pour assister au coucher du soleil. Malheureusement la France est bien trop éloignée.

12 - Akwáu ramé maã, asú maã França kití yepé minutu rupí amaã arama kurasí wapikasawa, ma França upitá apekatú retana.

13 - Mais, sur ta si petite planète, il te suffisait de tirer ta chaise de quelques pas.

13 - Ma, ne iwaka-retama upé, rerikuté remutirika xinga-ntu ne wapikawa.

14 - Et tu regardais le crépuscule chaque fois que tu le désirais...

14 - Yawé remaã-kwáu kurasí uwapika muíri í reputári waá ...

15 - "Un jour, j’ai vu le soleil se coucher quarante-quatre fois!"

15 - - Yepé ara, amaã kurasí uwapika 44 í!

$16-$ Et un peu plus tard tu ajoutais: 
16 - Ariré xinga indé remuapiri:

17 - "Tu sais... quand on est tellement triste on aime les couchers de soleil...

17 - - Indé rekwáu... mairamé sasiara yaikú, i katú yamaã-maã kurasí wapikasawa...

18 - - Le jour des quarante-quatre fois, tu étais donc tellement triste?"

18 - - Indé kuité sasiara retana reikú mairamé remaã kurasí uwapika 44 í?

19 - Mais le petit prince ne répondit pas.

19 - Ma muruxawamirĩ ti usuaxara nẽ maã.

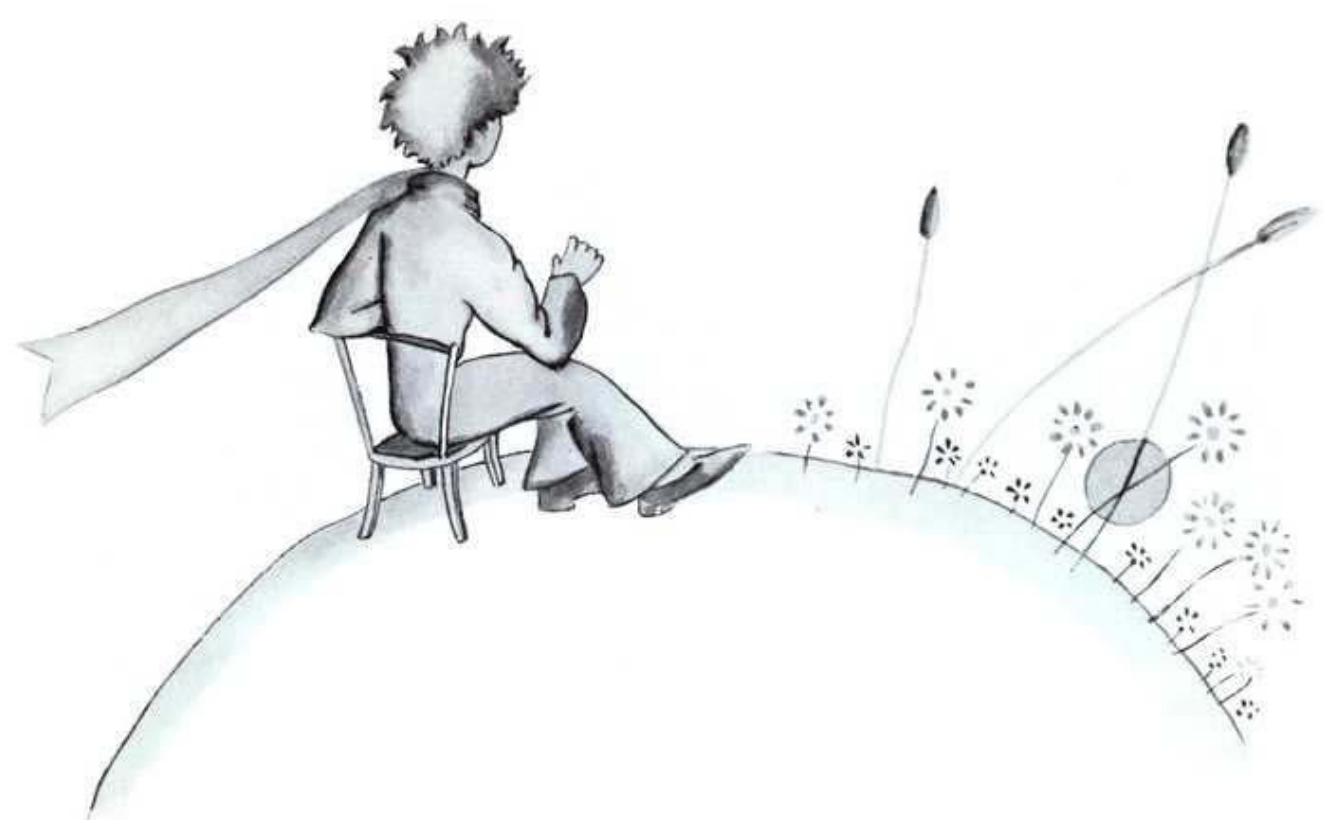

7

1 - Le cinquième jour, toujours grâce au mouton, ce secret de la vie du petit prince me fut révélé.

1 - Yepepusawa ara ramé, suumé mimbira rẽ resewara, akwáu manungara yumimiwera muruxawamirĩ rikwesawa resewara.

2 - Il me demanda avec brusquerie, sans préambule, comme le fruit d'un problème longtemps médité en silence:

2 - Aé kutara nungara upurandú se suí manungara umanduari pu uikú waá siía ara pukusawa: 
3 - "Un mouton, s'il mange les arbustes, il mange aussi les fleurs?

3 - - Yepé suumé mimbira, umbaú ramé yaitiwa, umbaú será putira yuíri?

4 - - Un mouton mange tout ce qu'il rencontre.

4 - - Eẽ, yepé suumé mimbira umbaú panhẽ maã aé uwasemu waá.

5 - - Même les fleurs qui ont des épines?

5 - - Aé yuíri umbaú putira-itá urikú waá tá yú-itá?

6 - - Oui. Même les fleurs qui ont des épines.

6 - - Eẽ, aé yuíri umbaú nhaã-itá.

7 - - Alors les épines, à quoi servent-elles?"

7 - - Kwayé, marã taá putira urikú i yú?

8 - Je ne le savais pas. J'étais alors très occupé à essayer de dévisser un boulon trop serré de mon moteur.

8 - Ti asuaxara-kwáu. Aramé ayuka-putari aikú yepé beruma ti waá usemu se pepusantá mukatakasara suí.

9 - J'étais très soucieux car ma panne commençait de m'apparaître comme très grave, et l'eau à boire qui s'épuisait me faisait craindre le pire.

9 - Amanduari kwera siía maã puxiwera resé ti resewara amungaturú-kwáu aikú se pepusantá, asuí arikú ií mirĩ-ntu aú arama. Sesewara asikié.

10 - "Les épines, à quoi servent-elles?"

10 - - Yú-itá... marã taá putira urikú i yú?

11 - Le petit prince ne renonçait jamais à une question, une fois qu'il l'avait posée.

11 - Muruxawamirĩ nẽ mairamé uxari tẽ yepé purandusawa umunhã riré aé.

12 - J'étais irrité par mon boulon et je répondis n'importe quoi:

12 - Mayé se piaíwa aikú nhaã beruma resewara, asuaxara maã-ntu:

13 - “Les épines, ça ne sert à rien, c’est de la pure méchanceté de la part des fleurs!

13 - - Yú-itá ti puranga, putira-itá urikú tá yú-itá nhaãsé aintá puxí!

$14-$ - Oh!”

14 - - Oh! 
15 - Mais après un silence il me lança, avec une sorte de rancune:

15 - Aé usarú xinga, asuí unheẽ ixé arama i piaíwa xinga:

16 - "Je ne te crois pas! Les fleurs sont faibles. Elles sont naïves. Elles se rassurent comme elles peuvent. Elles se croient terribles avec leurs épines..."

16 - - Ti aruyari ne resé! Putira-itá pitua. Aintá ti puxí. Tá uyupisirũ maã irumu tá urikú waá asuí tá uruyari tá kirimbawa retana tá yú-itá resewara...

17 - Je ne répondis rien. À cet instant-là je me disais: "Si ce boulon résiste encore, je le ferai sauter d'un coup de marteau."

17 - Ti asuaxara nẽ maã. Aramé amanduari: "Ti ramé usemu kwá beruma, asú ayuka aé yepé petekasara pupé."

18 - Le petit prince dérangea de nouveau mes réflexions:

18 - Ma muruxawamirĩ umuapatuka amú í se manduarisawa-itá:

19 - "Et tu crois, toi, que les fleurs...

19 - - Indé, indé remaité tẽ putira-itá...

20 - - Mais non! Mais non! Je ne crois rien! J'ai répondu n'importe quoi. Je m’occupe, moi, de choses sérieuses!"

20 - - Umbaá! Umbaá! Ti amaité nẽ maã! Asuaxara maã-ntu. Ti apitá amanduari tenhuntusawa resé!

21 - Il me regarda stupéfait.

21 - Aé umaã se resé akanhemusawa irumu:

22 - "De choses sérieuses!"

22 - - Tenhuntusawa!

23 - Il me voyait, mon marteau à la main, et le doigts noirs de cambouis, penché sur un objet qui lui semblait très laid.

23 - Aramé aikú se petekasara pupé se pú resé, i kiá mukatakasara resewara, asuí amuyawika yepé maã amurupí resé aé uwasemu waá kwera puxiwera retana.

24 - "Tu parles comme les grandes personnes!"

24 - - Indé repurungitá mayé mira-itá turusú yawé!

25 - Ça me fit un peu honte. Mais, impitoyable, il ajouta:

25 - Nhaã uxari ixé tĩsáwa irumu. Asuí, aé umuapiri santá: 
26 - "Tu confonds tout... tu mélanges tout!"

26 - - Indé ti remanduari puranga... indé remunani pawa!

27 - Il était vraiment très irrité. Il secouait au vent des cheveux tout dorés:

27 - Aé i piaíwa retana uikú tẽ. Iwitú umuwewé i awa itá-tawá nungara.

28 - "Je connais une planète où il y a un monsieur cramoisi. Il n'a jamais respiré une fleur.

28 - - Akwáu yepé iwaka-retama mamé umurari yepé apigawa piranga retana nẽ mairamé usetuna waá yepé putira sakwena.

29 - Il n'a jamais regardé une étoile. Il n'a jamais aimé personne. Il n'a jamais rien fait d'autre que des additions. Et toute la journée il répète comme toi:

29 - Aé yuíri nẽ mairamé umaã yepé yasitatá resé asuí nẽ mairamé usaisú nẽ awá. Aé usasá panhẽ ara umunhã-ntu paparisawa-itá, asuí muíri ara aé unheẽ mayé ne yawé:

30 - 'Je suis un homme sérieux! Je suis un homme sérieux!', et ça le fait gonfler d'orgueil. Mais ce n'est pas un homme, c'est un champignon!

30 - "Ti amanduari tenhuntusawa resé, ixé yepé apigawa murakisara! Ixé yepé apigawa murakisara!" Yawé surí aé upitá. Ma aé ti yepé apigawa, aé yepé urupé!

31 - - Un quoi?

31 - - Maã taá?

32 - - Un champignon!"

32 - - Yepé urupé!

33 - Le petit prince était maintenant tout pâle de colère.

33 - Muruxawamirĩ, aramé tẽ, i piaíwa piri uikú rẽ.

34 - "Il y a des millions d'années que les fleurs fabriquent des épines. Il y a des millions d'années que les moutons mangent quand même les fleurs.

34 - Aikwé ana tẽ siía akayú putira-itá urikú tá yú-itá. Aikwé ana tẽ siía akayú yuíri suumé mimbira-itá umbaú putira-itá, tá yú-itá irumu tẽ.

35 - Et ce n'est pas sérieux de chercher à comprendre pourquoi elles se donnent tant de mal pour se fabriquer des épines qui ne servent jamais à rien?

35 - Remaité tẽ yepé tenhuntusawa yandé yasikari yakwáu nhaãsé putira-itá urikú tá yú-itá ti ramé tá upisirũ kurí aintá? 
36 - Ce n'est pas important la guerre des moutons et des fleurs? C'est n'est pas plus sérieux et plus important que les additions d'un gros monsieur rouge?

36 - Yepé tenhuntusawa será suumé mimbira-itá maramunhangawa putira-itá irumu? Nhaã apigawa piranga paparisawa-itá, tá supiwara piri putira-itá mbeusawa suí?

37 - Et si je connais, moi, une fleur unique au monde, qui n'existe nulle part, sauf dans ma planète, et qu'un petit mouton peut anéantir d'un seul coup, comme ça, un matin, sans se rendre compte de ce qu'il fait, ce n'est pas important ça!”

37 - Akwáu ramé yepé putira amurupí amú-itá suí, uikú waá se retama upé, asuí, yepé kwema ramé, yepé suumé mimbira uyuká-kwáu aé, umaã-íma maã umunhã waá, - kwá yepé tenhuntusawa?!

38 - Il rougit, puis reprit:

38 - Suá upitá piranga, asuí umuapiri:

39 - "Si quelqu'un aime une fleur qui n'existe qu'à un exemplaire dans les millions et les millions d'étoiles, ça suffit pour qu'il soit heureux quand il les regarde.

39 - - Amú awá usaisú ramé yepé putira amurupí panhẽ suí, kwá i katú ana umusurí arã aé mairamé umaã kwá putira resé.

40 - Il se dit: 'Ma fleur est là quelque part...'

40 - Yawé, aé umanduari-kwáu: "Se putira uikú yepé tendawa kití..."

41 - Mais, si le mouton mange la fleur, c'est pour lui comme si, brusquement, toutes les étoiles s'éteignaient! Et ce n'est pas important ça!"

41 - Ma, suumé mimbira umbaú ramé putira, awá supé usaisú aé mayé panhẽ yasitatá uxari tá uwerá ramé maã! Kwá yepé tenhuntusawa?!

42 - Il ne put rien dire de plus. Il éclata brusquement en sanglots. La nuit était tombée. J'avais lâché mes outils.

42 - Asuí, ti ana unheẽ nẽ maã. Aramé tẽ aé uyupirũ uyaxiú. Pituna usika. Axari se murakí rupiara-itá.

43 - Je me moquais bien de mon marteau, de mon boulon, de la soif et de la mort.

43 - Ayupirũ apuká petekasara resé, beruma resé, isisawa resé asuí manũsawa resé.

44 - Il y avait, sur une étoile, une planète, la mienne, la Terre, un petit prince à consoler!

44 - Aramé aikwé, yepé iwaka-retama upé, se yara, sera waá Iwí, yepé muruxawamirĩ amurí arama! 
45 - Je le pris dans le bras. Je le berçai. Je lui disais: "La fleur que tu aimes n'est pas en danger... Je lui dessinerai une muselière, à ton mouton... Je te dessinerai une armure pour ta fleur... Je..."

45 - Asupiri aé se yuwá resé, amuyatimú aé. Asuí anheẽ: "Putira resaisú waá uikú katú... Akwatiari kurí yepé yurú-pukwarisara ne suumé mimbira supé... asuí yepé kurara ne putira supé... Ixé..."

46 - Je ne savais pas trop quoi dire. Je me sentais très maladroit. Je ne savais comment l'atteindre, où le rejoindre... C'est tellement mystérieux, le pays des larmes!

46 - Aramé ti akwáu maã unheẽ i xupé. Aikú tĩsáwa irumu. Ti akwáu mayé amurí aé, mayé ayumuruakí sesé... Nẽ awá ukwáu supí sesayukisé retama!
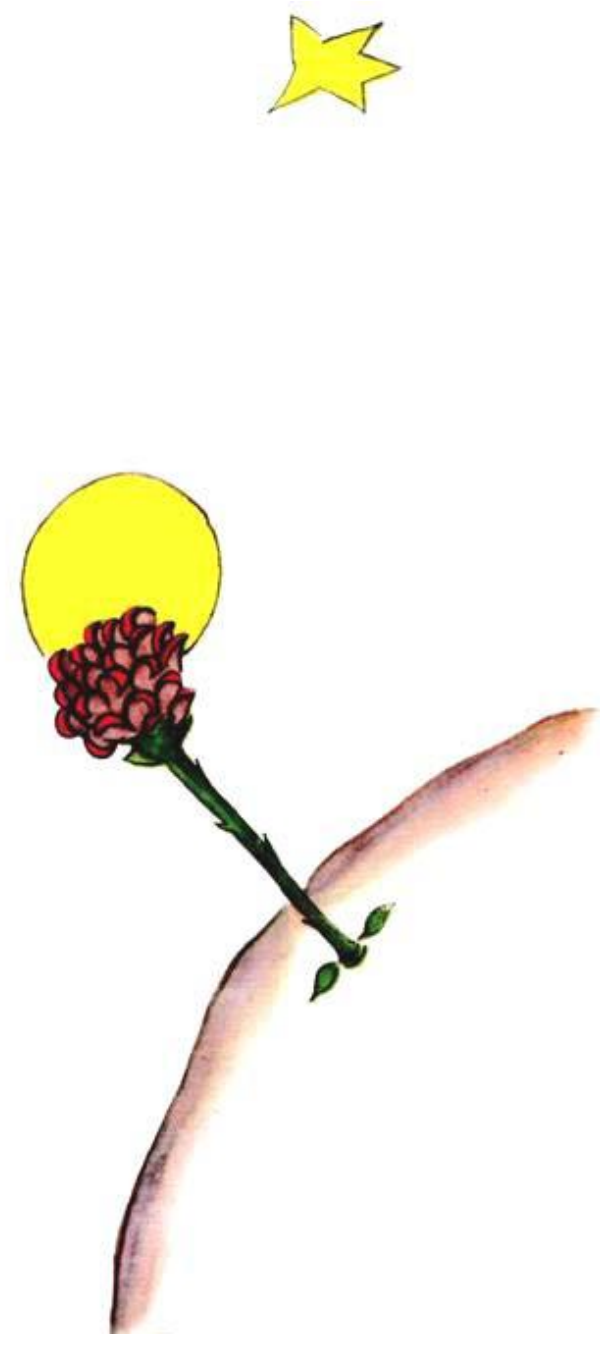
1 - J'appris bien vite à mieux connaître cette fleur. Il y avait toujours eu, sur la planète du petit prince, des fleurs très simples, ornées d'un seul rang de pétales, et qui ne tenaient point de place, et qui ne dérangeaient personne.

1 - Kutara nungara ayumbué akwáu katú piri nhaã putira. Panhẽ mairamé kwera aikwé ana muruxawamirĩ retama upé, putira-itá siía-íma putira-rawa. Aintá kwaíra, asuí nẽ mairamé tá umuapatuka nẽ awá.

2 - Elles apparaissaient un matin dans l'herbe, et puis elles s'éteignaient le soir.

2 - Tá uyukwáu kwema ramé, asuí karuka pausawa ramé tá susanga-íma.

3 - Mais celle-là avait germé un jour, d'une graine apportée d'on ne sait où, et le petit prince avait surveillé de très près cette brindille qui ne ressemblait pas aux autres brindilles.

3 - Ma nhaã putira usemu yepé tainha suí uri waá yepé tendawa suí mamé nẽ awá ukwáu. Sesewara muruxawamirĩ umanhã-manhana kwá putiramirĩ, amurupí retana waá amú-itá suí.

4 - Ça pouvait être un nouveau genre de baobab. Mais l'arbuste cessa vite de croître, et commença de préparer une fleur.

4 - Araneíma nhaã putira baobá nungara. Ma kutara nungara aé upituú uyumunhã, asuí yepé putira uyupirũ usemu sesé.

5 - Le petit prince, qui assistait à l'installation d'un bouton énorme, sentait bien qu'il en sortirait une apparition miraculeuse, mais la fleur n'en finissait pas de se préparer à être belle, à l'abri de sa chambre verte.

5 - Muruxawamirĩ, umaã waá kwera yepé putira-resá turusú retana uyukwáu, ukwáu tẽ usika uikú manungara puranga retana nhaã tendawa upé, ma nhã̃ putira nẽ mairamé umupawa uyumupuranga, i ukapí yakira kwara upé.

6 - Elle choisissait avec soin ses couleurs. Elle s'habillait lentement, elle ajustait un à un ses pétales.

6 - Ape, aé uparawaka katú reté i pinimasawa-itá. Uyumuamundéu merupí asuí umupuranga muíri putira-rawa.

7 - Elle ne voulait pas sortir toute fripée comme les coquelicots. Elle ne voulait apparaitre que dans le plein rayonnement de sa beauté.

7 - Aé ti uyukwáu-putari puxiwera mayé amú-itá putira yawé, usemu-putari mairamé-ntu puranga retana uikú maã.

8 - Eh! oui. Elle était très coquette! Sa toilette mystérieuse avait donc duré des jours et des jours. 
8 - Eẽ, eré, aé yepé putira warixí retana! Uikupukú tẽ siía ara uyumupuranga arama.

9 - Et puis voici qu'un matin, justement à l'heure du lever du soleil, elle s'était montrée.

9 - Ma, yepé kwema ramé, mairamé kurasí usemu uikú, aé uyukwáu.

10 - Et elle, qui avait travaillé avec tant de précision, dit en bâillant:

10 - Aramé, uyumupuranga riré siía ara pukusawa, aé unheẽ tipusimanha xinga:

11 - "Ah! je me réveille à peine... Je vous demande pardon... Je suis encore toute décoiffée..."

11 - - Ah, apaka kuíri tẽ... Reyerũ ixé... Se awa ti rẽ uikú puranga...

12 - Le petit prince, alors, ne put contenir son admiration:

12 - Muruxawamirĩ i akanhemu mairamé umaã aé:

13 - "Que vous êtes belle!"

13 - - Indé puranga retana!

14 - - N'est-ce pas, répondit doucement la fleur. Et je suis née en même temps que le soleil..."

14 - - Supí, ixé puranga - usuaxara seẽ nhaã putira. - Asemu yepewasú kurasí irumu...

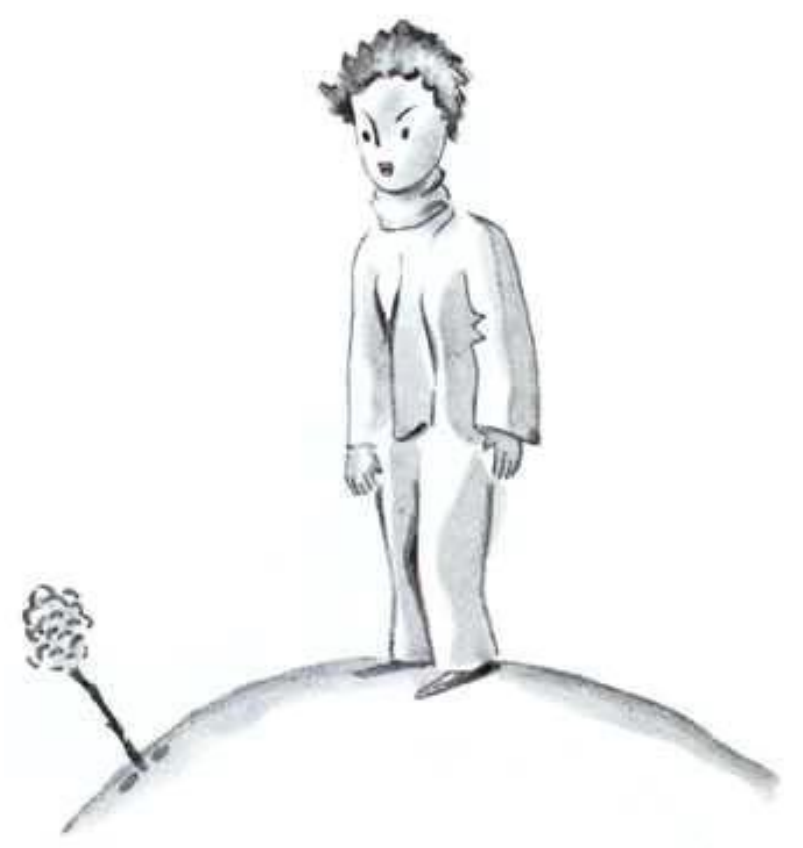


15 - Le petit prince devina bien qu'elle n'était pas trop modeste, mais elle était si émouvante!

15 - Muruxawamirĩ ukwáu kutara nungara aé yepé putira warixí, ma aé puranga retana!

16 - “C'est l'heure, je crois, du petit déjeuner, avait-elle bientôt ajouté, auriez-vous la bonté de penser à moi..."

16 - - Amaité, kuíri tẽ, uwatari ixé arã se kwema mbausawa - unheẽ putira. - Indé remanduari-kwáu maã se resewara...

17 - Et le petit prince, tout confus, ayant été chercher un arrosoir d'eau fraîche, avait servi la fleur.

17 - Aramé, muruxawamirĩ, i apatuka pawa, usikari riré yepé mururusara, umururú putira ií irusangarana irumu.

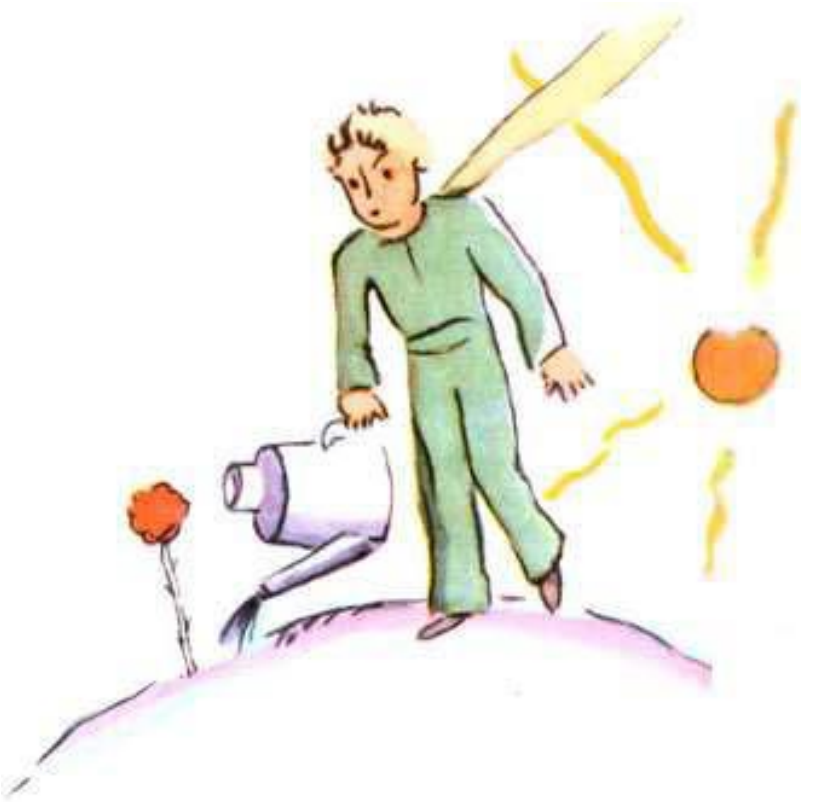

18 - Ainsi l'avait-elle bien vite tourmenté par sa vanité un peu ombrageuse. Un jour, par exemple, parlant de ses quatre épines, elle avait dit au petit prince:

18 - Ariré, mayé nhaã putira upurungitawera-ntu sesewara tẽ, muruxawamirĩ i piaíwa upitá ana uikú. Yepé ara, mairamé umbeú i irundí yú resewara, unheẽ i xupé:

19 - "Ils peuvent venir, les tigres, avec leurs griffes!

19 - - Yawareté-pinima-itá, tá uyukwáu-kwáu tá puampé irumu! 


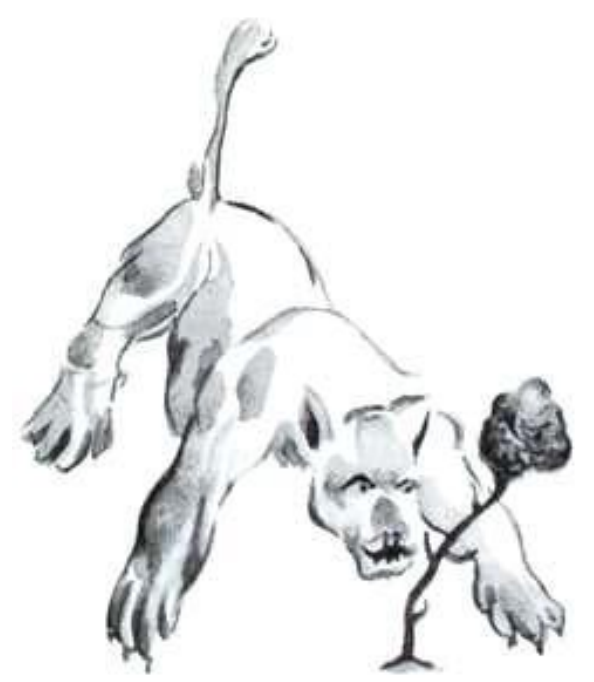

20 - - Il n'y a pas de tigres sur ma planète, avait objecté le petit prince, et puis les tigres ne mangent pas d'herbe.

20 - - Ti yamaã yawareté-pinima-itá se retama upé - unheẽ muruxawamirĩ. - Asuí, yawareté-pinima-itá ti umbaú mitima-itá.

21 - - Je ne suis pas une herbe, avait doucement répondu la fleur.

21 - - Ixé ti yepé mitima - nhaã putira usuaxara seẽ.

22 - - Pardonnez-moi...

22 - - Reyerũ ixé...

23 - - Je ne crains rien des tigres, mais j'ai horreur des courants d'air. Vous n'auriez pas un paravent?"

23 - - Ti asikié yawareté-pinima suí, ma ti tẽ asaisú mairamé iwituwasú utuká se resé. Rerikú será yepé iwitú-pitasukasara ixé arã?

24 - "Horreur des courants d'air... ce n'est pas de chance, pour une plante, avait remarqué le petit prince. Cette fleur est bien compliquée..."

24 - "Aé ti usaisú mairamé iwituwasú utuká sesé... Kwá ti i katú yepé íwa supé”, umanduari muruxawamirĩ. "Aé yepé putira iwasú retana..."

25 - “Le soir vous me mettrez sous globe. Il fait très froid chez vous. C'est mal installé. Là d'où je viens..."

25 - - Pituna ramé, remburi kurí ixé yepé riruwasú sakakanga upé. Ne rendawa irusanga retana. Ti asasá puranga. Masuí ayuri...

26 - Mais elle s'était interrompue. Elle était venue sous forme de graine. Elle n'avait rien pu connaître des autres mondes. 
26 - Ma aé tẽ ukirirĩ. Aé uri nhaã iwaka-retama kití mairamé aé yepé tainha. Ti ukwáu nẽ maã amú-itá tetama resewara.

27 - Humiliée de s'être laissé surprendre à préparer un mensonge aussi naïf, elle avait toussé deux ou trois fois, pour mettre le petit prince dans son tort:

27 - Tĩsáwa irumu ti resewara unheẽ supisawa, aé utusé mukũi u musapiri í, asuí, umunhã arama muruxawamirĩ uyusaã puxiwera, unheẽ:

28 - "Ce paravent?...

28 - - Mamé taá uikú se iwitú-pitasukasara?

29 - - J'allais le chercher mais vous me parliez!”

29 - - Apisika arã waá kwera aé, ma indé repurungitá...

30 - Alors elle avait forcé sa toux pour lui infliger quand même des remords.

30 - Aramé aé utusé-putari amú í uxari arama-ntu aé puxiwera.

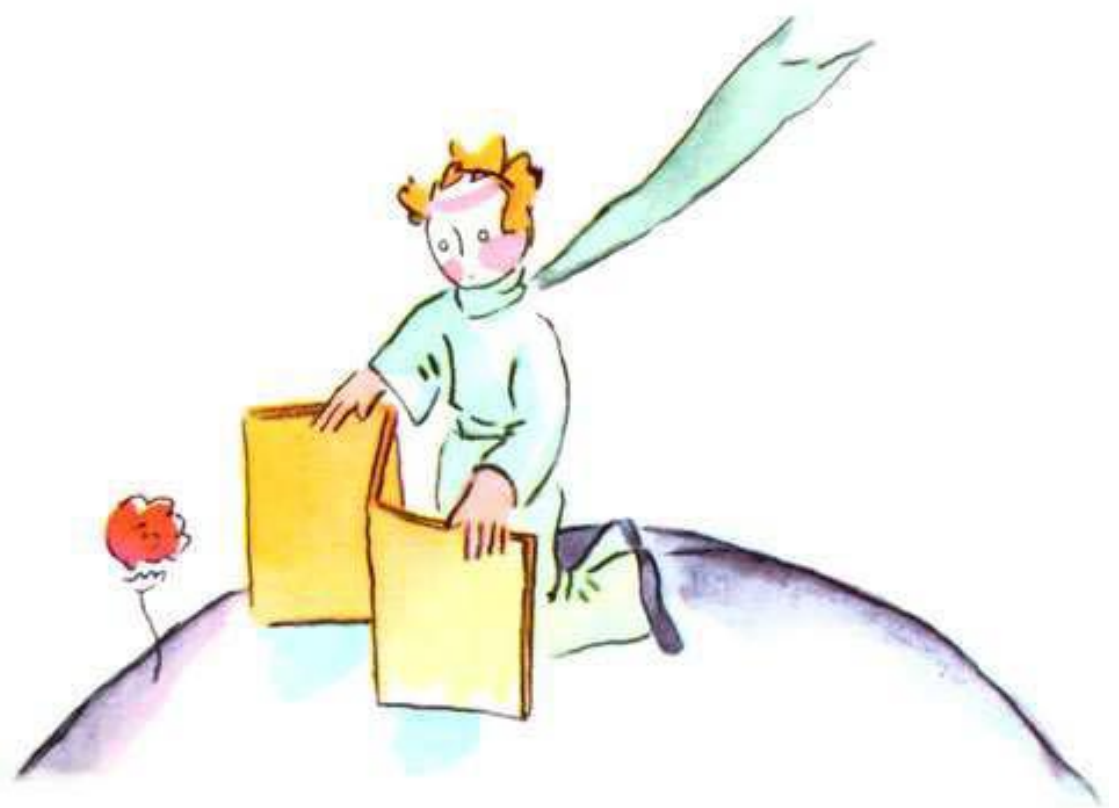

31 - Ainsi le petit prince, malgré la bonne volonté de son amour, avait vite douté d'elle.

31 - Sesewara muruxawamirĩ, usaisú supí waá nhã̃ putira, uyupirũ ana uikú ti uruyari i nheenga-itá resé.

32 - Il avait pris au sérieux des mots sans importance, et était devenu très malheureux.

32 - Aé uruyari nheenga-itá tenhuntuwara resé uxari waá-itá aé sasiara retana.

33 - “J'aurais dû ne pas l'écouter, me confia-t-il un jour, il ne faut jamais écouter les fleurs. 
33 - "Ti arã waá kwera asendú aé", aé unheẽ ixé arama yepé ara, "nẽ mairamé yaruyari-kwáu putira-itá resé.

34 - Il faut les regarder et les respirer. La mienne embaumait ma planète, mais je ne savais pas m'en réjouir.

34 - I katú yamaã-ntu aintá resé asuí yasetuna aintá sakwena. Se yara umusakwena se retama pawa, ma ti akwáu mayé ayumuruakí sesé.

35 - Cette histoire de griffes, qui m'avait tellement agacé, eût dû m'attendrir...”

35 - Nhaã mbeusawa puampé-itá resewara umupiaíwa waá kwera ixé, kuíri ti ana uyuakí se irumu..."

36 - Il me confia encore:

36 - Asuí unheẽ rẽ ixé arama:

37 - 'Je n'ai alors rien su comprendre! J'aurais dû la juger sur les actes et non sur les mots.

37 - “Ti akwáu nẽ maã sesewara! Puranga piri maã amanduari ramé sesé maã-itá rupí umunhã waá, ti nheenga-itá rupí unheẽ waá.

38 - Elle m'embaumait et m'éclairait. Je n'aurais jamais dû m'enfuir!

38 - Aé umusakwena ixé asuí umusurí ixé. Ti arama waá kwera axari aé yepenhũ!

39 - J'aurais dû deviner sa tendresse derrière ses pauvres ruses.

39 - Ixé amaã arama waá kwera i seẽsawa, uyuyumimi waá i puité-itá tenhutuwara pitérupi.

40 - Les fleurs sont si contradictoires! Mais j'étais trop jeune pour savoir l'aimer."

40 - Putira-itá iwasú tẽ! Ma pisasú retana rẽ ixé akwáu arã asaisú aé." 


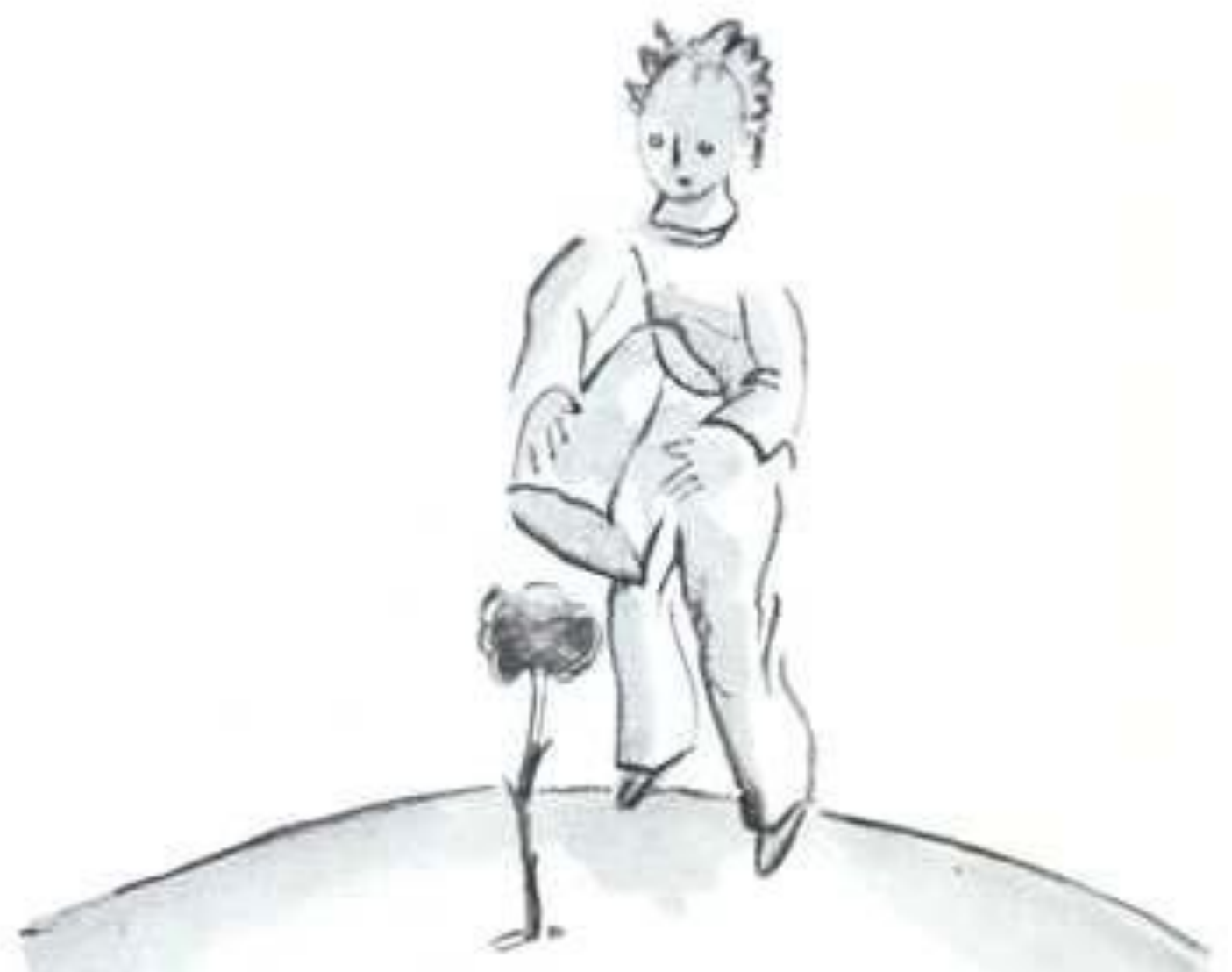




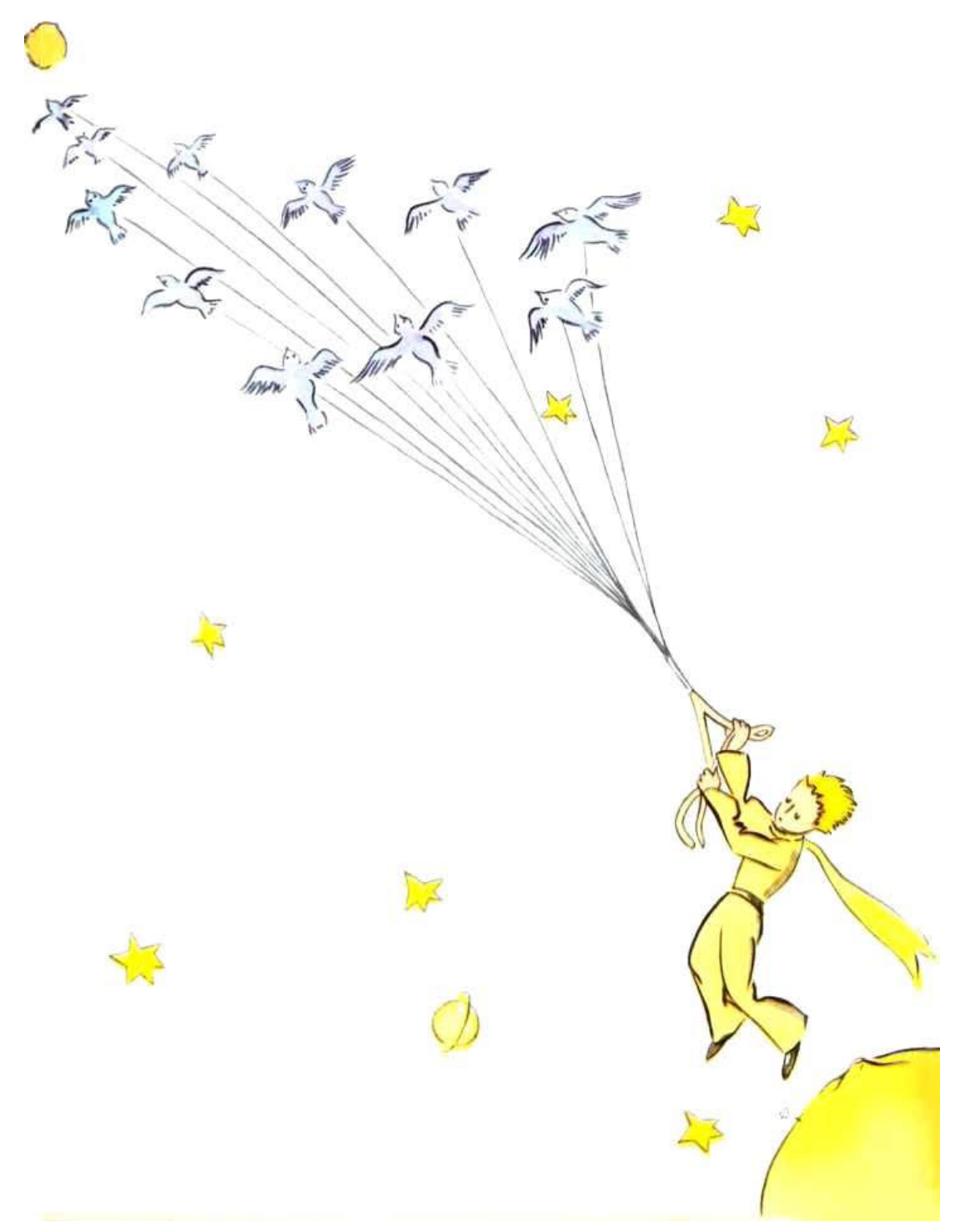

1 - Je crois qu'il profita, pour son évasion, d'une migration d'oiseaux sauvages.

1 - Aruyari aé uyawáu yepé wirá kaapura riía irumu, mairamé tá uwewé amú tendawa kití.

2 - Au matin du départ il mit sa planète bien en ordre. Il ramona soigneusement ses volcans en activité.

2 - Kwema ramé usemu waá, umungaturú setama pawa. Uyusí katú i iwitepukaitá upuka rẽ waá.

3 - Il possédait deux volcans en activité. Et c'était bien commode pour faire chauffer le petit déjeuner du matin.

3 - Aé urikú mukũi iwitepuka upuka rẽ waá. Puranga umuakú arama tá resé kwema mbausawa. 
4 - Il possédait aussi un volcan éteint. Mais, comme il disait: “On ne sait jamais!" Il ramona donc également le volcan éteint.

4 - Urikú yuíri yepé iwitepuka uwéu uikú waá. Ma, mayé unheẽwéra: "Nẽ mairamé yakwáu maã uyusasá kurí!” Yawé uyusí yuíri nhaã uwéu uikú waá.

5 - S'ils sont bien ramonés, les volcans brûlent doucement et régulièrement, sans éruptions.

5 - Yayusí katú ramé iwitepuka-itá, aintá ukái merupí asuí ti tá upuka.

6 - Les éruptions volcaniques sont comme des feux de cheminée.

6 - Mairamé yepé iwitepuka upuka, aé umusému tatá kwera mayé yepé tatá rendawa yawé.

7 - Évidemment sur notre terre nous sommes beaucoup trop petits pour ramoner nos volcans.

7 - Ma Iwí upé yandé kwaíra retana yayusí arama yané iwitepuka.

8 - C'est pourquoi ils nous causent des tas d'ennuis.

8 - Sesewara tá yawaité retana yané retama upé.

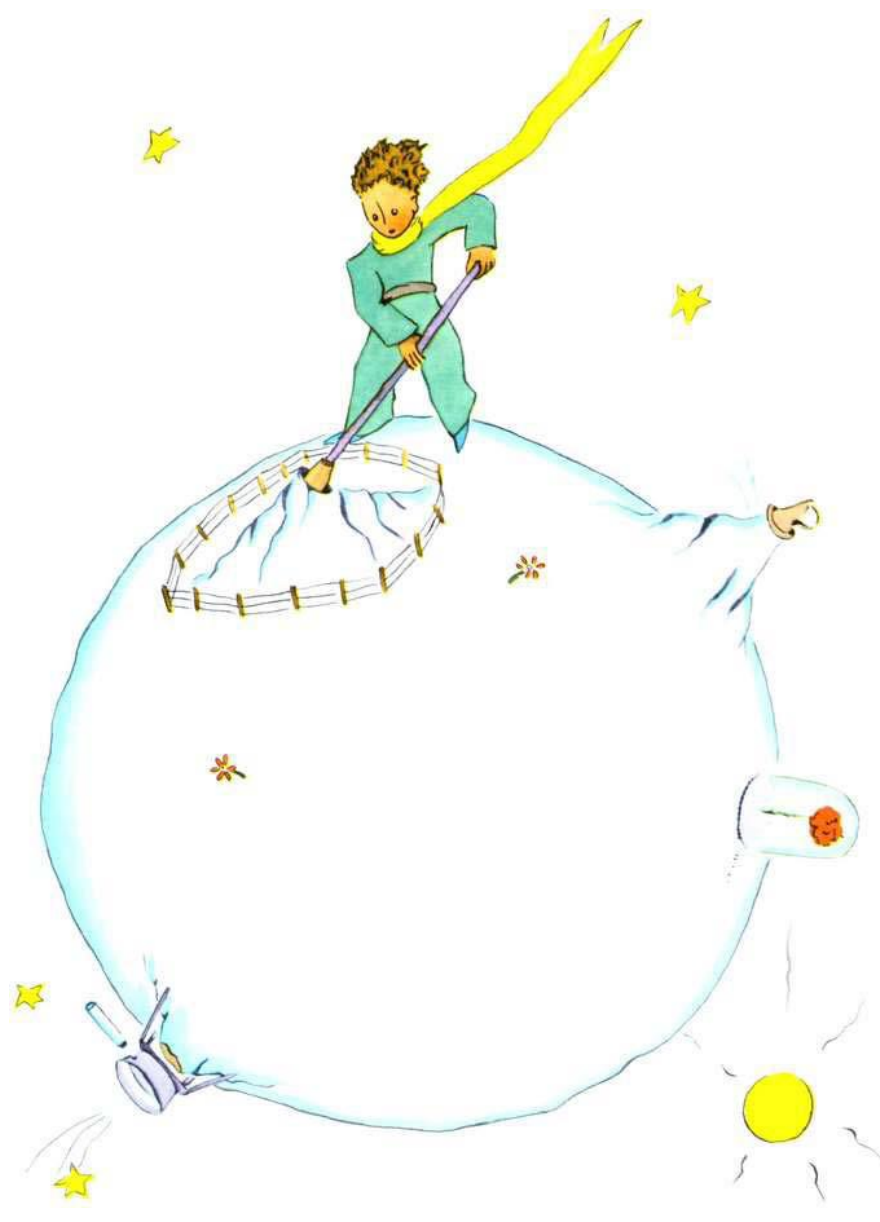


9 - Le petit prince arracha aussi, avec un peu de mélancolie, les dernières pousses de baobabs.

9 - Muruxawamirĩ, sasiara xinga, uyuka yuíri yepé-yepé baobá íwa.

10 - Il croyait ne jamais devoir revenir.

10 - Aramé umanduari uikú ti uyuíri setama kití.

11 - Mais tous ces travaux familiers lui parurent, ce matin-là, extrêmement doux.

11 - Ma, nhaã kwema ramé, murakí-itá umunhãwera waá muíri ara tá umusurí piri muruxawamirĩ.

12 - Et, quand il arrosa une dernière fois la fleur, et se prépara à la mettre à l'abri sous son globe, il se découvrit l'envie de pleurer.

12 - Asuí mairamé muruxawamirĩ umururú putira anhuarama rupí, umburi renundé aé riruwasú sakakanga upé, umaã aé uyaxiú-putari.

13 - “Adieu”, dit-il à la fleur.

13 - - Asú rẽ ne suí - unheẽ putira supé.

14 - Mais elle ne lui répondit pas.

14 - Ma putira ti usuaxara.

15 - “Adieu”, dit-il à la fleur.

15 - - Asú rẽ ne suí - unheẽ amú í.

16 - La fleur toussa. Mais ce n'était pas à cause de son rhume.

16 - Putira utusé. Ma ti irusangasawa resewara.

17 - “J'ai été sotte, lui dit-elle enfin. Je te demande pardon. Tâche d'être heureux."

17 - - Ixé yepé putira yakwaíma - unheẽ muruxawamirĩ supé. Reyerũ ixé. Resikari ne rurisawa.

18 - Il fut surpris par l'absence de reproches. Il restait là tout déconcerté, le globe en l'air.

18 - Aé i akanhemu putira nheenga-itá irumu. Ti ana ukwáu maã umunhã, riruwasú sakakanga irumu i pú resé.

19 - Il ne comprenait pas cette douceur calme.

19 - Ti ukwáu supisawa nhaã nheenga-itá seẽ resewara. 
20 - “Mais oui, je t'aime, lui dit la fleur. Tu n'en as rien su, par ma faute. Cela n'aucune importance.

20 - - Asaisú retana indé - putira unheẽ i xupé. - Ti rẽ rekwáu kwá se resewara. Ma, kuíri, ti repitá remanduari se nheenga-itá resé.

21 - Mais tu as été aussi sot que moi. Tâche d'être heureux... Laisse ce globe tranquille. Je n'en veux plus.

21 - Ma indé yakwaíma mayé se yawé. Resikari ne rurisawa... Rexari kwá riruwasú sakakanga. Ti ana aputari piri aé.

22 - - Mais le vent...

22 - - Ma iwitú...

23 - - Je ne suis pas si enrhumée que ça... L'air frais de la nuit me fera du bien. Je suis une fleur.

23 - - Ti irusangasawa retana aikú tẽ... Pituna ramé iwitú irusangarana umunhã kurí ixé ayusaã katú. Ixé yepé putira.

24 - - Mais les bêtes...

24 - - Ma suú-itá...

25 - - Il faut bien que je supporte deux ou trois chenilles si je veux connaître les papillons.

25 - - Arikuté apitasuka mukũi u musapiri tapurú, akwáu-putari ramé panapanãitá.

26 - Il paraît que c'est tellement beau. Sinon qui me rendra visite? Tu seras loin, toi.

26 - Tá unheẽ aintá puranga retana. Ti ramé kwayé, awá taá uri kurí umaã ixé? Indé apekatú reikú kurí.

27 - Quant aux grosses bêtes, je ne crains rien. J'ai mês griffes."

27 - Suú-itá turusú resewara, ti asikié aintá suí. Arikú se puampé-itá.

28 - Et elle montrait naïvement ses quatre épines. Puis elle ajouta:

28 - Aramé umukameẽ i irundí yú. Asuí, umuapiri:

29 - "Ne traîne pas comme ça, c'est agaçant. Tu as décidé de partir. Va-t'en."

29 - - Té reikupukú resemu arã kwá suí, se piaíwa apitá ana aikú. Indé resemuputari kwá suí, resemu kuíri tẽ!

30 - Car elle ne voulait pas qu'il la vît pleurer C'était une fleur tellement orgueilleuse... 
30 - Aé ti maã uputari muruxawamirĩ umaã aé uyaxiú. Aé yepé putira warixí retana...

\section{0}

1 - Il se trouvait dans la région des astéroïdes 325, 326, 327, 328, 329 et 330.

1 - Aé uikú yepé-yepé iwaka-retama ruakí: 325, 326, 327, 328, 329, 330.

2 - Il commença donc par les visiter pour y chercher une occupation et pour s'instruire.

2 - Aramé uyupirũ uwatá kwá tetama-itá rupí usikari arama maã umunhã asuí ukwáu arama aintá resewara.

3 - Le premier était habité par un roi. Le roi siégeait, habillé de pourpre et d'hermine, sur un trône très simple et cependant majestueux.

3 - Yepesawa iwaka-retama upé aikwé yepé muruxawa. Muruxawa umundéu waá kwera yepé muamundewa piranga asuí murutinga, uwapika uikú yepé wapikawawasú upé, ti waá kwera sepiasú, ma puranga retana.

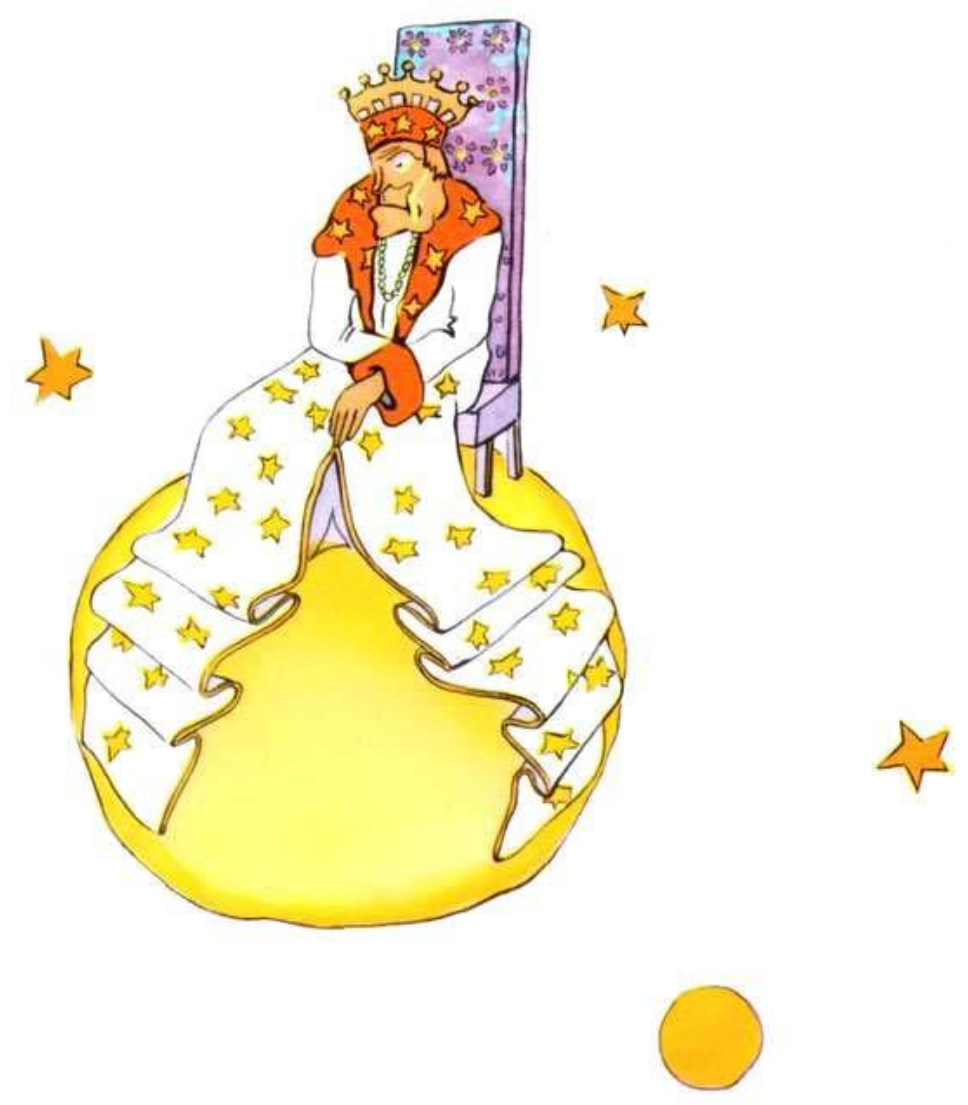

4 - “Ah! Voilá un sujet!”, s’écria le roi quand il aperçut le petit prince.

4 - - Ah! Xukúi yepé miasua! - unheẽ muruxawa mairamé umaã muruxawamirĩ. 
5 - Et le petit prince se demanda: “Comment peut-il me reconnaître puisqu'il ne m'a encore jamais vu!"

5 - Aramé muruxawamirĩ umanduari: “Ti mayé aé ukwáu ixé nhaãsé nẽ mairamé umaã ixé!"”

6 - Il ne savait pas que, pour les rois, le monde est très simplifié. Tous les hommes sont des sujets.

6-Aé ti ukwáu muruxawa-itá supé panhẽ awá tá miasua.

7 - "Approche-toi que je te voie mieux", lui dit le roi qui était tout fier d'être enfin roi pour quelqu'un.

7 - - Reyumuruakí se resé amaã puranga arã indé - unheẽ muruxawa, surí uikú waá nhaãsé aikwé yepé miasua setama upé.

8 - Le petit prince chercha des yeux où s'asseoir, mais la planète était tout encombrée par le magnifique manteau d'hermine.

8 - Muruxawamirĩ usikari yepé tendawa uwapika arama, ma nhaã iwaka-retama upupeka ana uikú muamundewa turusú retana rupí muruxawa waá umundeuwera.

9 - Il resta donc debout, et, comme il était fatigué, il bâilla.

9 - Aramé aé upitá mamé uikú waá. Ma mayé i kweré asuí tipusí irumu, uyupirũ upirari i yurú.

10 - "Il est contraire à l'étiquette de bâiller en présence d'un roi, lui dit le monarque. Je te l'interdis.

10 - - Ti arã indé repirá-pirari ne yurú yepé muruxawa ruakí - muruxawa unheẽ. Atimuapú indé.

11 - - Je ne peux pas m'en empêcher, répondit le petit prince tout confus. J'ai fait un long voyage et je n'ai pas dormi...

11 - - Ti apituú-kwáu - muruxawamirĩ unheẽ tĩsáwa irumu. - Ixé awatá siía ara pukusawa asuí ti rẽ akiri-kwáu...

12 - - Alors, lui dit le roi, je t'ordenne de bâiller. Je n'ai vu personne bâiller depuis des années.

12 - - Yawé - unheẽ muruxawa - amundú indé repirá-pirari ne yurú. Ti ana amaã nẽ awá upirá-pirari i yurú aikwé siía akayú.

13 - Les bâillements sont pour moi des curiosités. Allons! bâille encore. C'est un ordre.

13 - Kwá amurupí retana se retama upé. Resú, repirá-pirari ne yurú! Kwá yepé mundusawa! 
14 - - Ça m'intimide... je ne peux plus..., fit le petit prince tout rougissant.

14 - - Yawé apitá tĩsáwa irumu... yawé ti ukwáu... - unheẽ muruxawamirĩ.

15 - - Hum! Hum! répondit le roi. Alors je... je t'ordonne tantôt de bâiller et tantôt de..."

15 - - Hum! Hum! - usuaxara muruxawa. - Yawé ixé... ixé amundú indé amuramé repirá-pirari ne yurú, amuramé...

16 - Il bredouillait un peu et paraissait vexé.

16 - Aé uyumuapatuka xinga asuí uikú pu tĩsáwa irumu.

17 - Car le roi tenait essentiellement à ce que son autorité fût respectée. Il ne tolérait pas la désobeissance.

17 - Muruxawa uputari tẽ panhẽ awá upusú aé. Ti uxari mira-itá ti tá upusú aé.

18 - C'était un monarque absolu. Mais, comme il était très bon, il donnait des ordres raisonnables.

18 - Aé yepé muruxawa umundú waá setama pawa resé, ma mayé aé yepé apigawa katú retana, umanduariwera retana uyururéu renundé manungara yepé miasua suí.

19 - “Si j'ordonnais, disait-il couramment, si j'ordonnais à un général de se changer en oiseau de mer, et si le général n'obéissait pas, ce ne serait pas la faute du géneral. Ce serait ma faute."

19 - “Amundú ramé maã", unheẽwera, "yepé miasua muruxawawara uyeréu yepé paranawasú wirá arã asuí aé ti upusú maã ixé, ti maã i yawisawa, ma se yara.

20 - “Puis-je m'asseoir? s'enquit timidement le petit prince.

20 - - Awapika-kwáu será? - muruxawamirĩ upurundú tĩsáwa xinga irumu.

21 - - Je t'ordonne de t'asseoir', lui répondit le roi, qui ramena majestueusement un pan de son manteau d'hermine.

21 - - Amundú indé rewapika - muruxawa usuaxara i xupé, asuí usikí i muamundewa pisãwéra.

22 - Mais le petit prince s'étonnait. La planète était minuscule. Sur quoi le roi pouvait-il bien régner?

22 - Ma muruxawamirĩ i akanhemu. Nhã̃ yepé iwaka-retama mirĩ retana. Yawé, muruxawa umundú awá resé?

23 - "Sire, lui dit-il... je vous demande pardon de vous interroger... 
23 - - Muruxawa... - muruxawamirĩ unheẽ - reyerũ ixé, apurandú-kwáu manungara ne suí?...

24 - - Je t'ordonne de m'interroger, se hâta de dire le roi.

24 - - Amundú indé remunhã yepé purandusawa - kutara nungara unheẽ muruxawa.

25 - - Sire... sur quoi régnez-vous?

25 - - Muruxawa... indé remundú awá resé?

26 - - Sur tout, répondit le roi, avec une grande simplicité.

26 - - Panhẽ awá resé - muruxawa usuaxara kwayé-ntu.

27 - - Sur tout?"

27 - - Panhẽ awá resé?

28 - Le roi d'un geste discret désigna sa planète, les autres planètes et les étoiles.

28 - Aramé muruxawa umukameẽ setama, amú-itá iwaka-retama, yasitatá-itá yuíri.

29 - "Sur tout ça? dit le petit prince.

29 - - Panhẽ awá resé será? - muruxawamirĩ unheẽ.

30 - - Sur tout ça...”, répondit le roi.

30 - - Eẽ, panhẽ awá resé tẽ... - muruxawa usuaxara.

31 - Car non seulement c'était un monarque absolu mais c'était un monarque universel.

31 - Aé ti yepé muruxawa umundú waá setama resé-ntu, aé umundú yuíri panhẽ iwaka-retama resé.

32 - "Et les étoiles vous obéissent?

32 - - Yasitatá-itá upusú indé?

33 - - Bien sûr, lui dit le roi. Elles obéissent aussitôt. Je ne tolère pas l'indiscipline.”

33 - - Eẽ, panhẽ yasitatá - muruxawa unheẽ. Aintá kutara nungara upusú ixé. Atimuapú pususawa-íma.

34 - Un tel pouvoir émerveilla le petit prince.

34 - Panhẽ nhaã uyuakí muruxawamirĩ irumu. 
35 - S'il l'avait détenu lui-même, il aurait pu assister, non pas à quarante-quatre, mais à soixante-douze, ou même à cent, ou même à deux cents couchers de soleil dans la même journée, sans avoir jamais à tirer sa chaise!

35 - Aé umundú ramé maã panhẽ yasitatá resé, umaã-kwáu maã kurasí wapikasawa mairamé uputari maã. Umaã-kwáu maã tẽ siía kurasí wapikasawa yepé-ntu ara ramé, asuí ti maã urikuté umutirika i wapikawa.

36 - Et comme il se sentait un peu triste à cause du souvenir de sa petite planète abandonnée, il s'enhardit à solliciter une grâce du roi:

36 - Aramé, mayé uyusaã sasiara xinga nhaãsé setama uwatari i xupé, umunhãputari yepé yurureusawa muruxawa supé:

37 - "Je voudrais voir un coucher de soleil... Faites-moi plaisir... Ordonnez au soleil de se coucher...

37 - - Se rurí apitá maã ixé amaã-kwáu ramé maã yepé kurasí wapikasawa... Remunhã kwá ixé arã... Remundú kurasí uwapika...

38 - Si j'ordonnais à un géneral de voler d'une fleur à l'autre à la façon d'un papillon, ou d'écrire une tragédie, ou de se changer en oiseau de mer, et si le géneral n'exécutait pas l'ordre reçu, qui, de lui ou de moi, serait dans son tort?

38 - - Amundú ramé maã yepé miasua muruxawawara uwewé yepé putira suí té amú putira mayé panapanã yawé u umupinima yepé papera pukú u uyeréu paranawasú wirá arã, ma aé ti maã upusú ixé, awá taá uyawí maã uikú, aé u ixé?

39 - - Ce serait vous, dit fermement le petit prince.

39 - - Indé tẽ - muruxawamirĩ usuaxara sikiesawa-íma.

40 - - Exact. Il faut exiger de chacun ce que chacun peut donner, reprit le roi.

40 - - Eré, yarikuté yayururéu mira-itá suí nhaã-ntu aintá umeẽ-kwáu waá yandé arã - unheẽ muruxawa.

41 - - L'autorité repose d'abord sur la raison. Si tu ordonnes à ton peuple d'aller se jeter à la mer, il fera la révolution.

41 - - Yarikuté yamanduari katú yayururéu renundé maã-ntu. Remundú ramé ne miasua-itá uiké yepé paranã yawaité upé, aintá nẽ mairamé upusú indé.

42 - J'ai le droit d'exiger l'obéissance parce que mes ordres sont raisonnables.

42 - Ixé aputari-kwáu mira-itá upusú ixé nhaãsé amanduari katú ayururéu renundé maã-ntu aintá suí.

43 - - Alors mon coucher de soleil? rappela le petit prince qui jamais n'oubliait une question une fois qu'il l'avait posée. 
43 - - Kurasí wapikasawa resewara? - upurandú muruxawamirĩ, nhaãsé aé nẽ mairamé sesarái yepé purandusawa suí umunhã ana waá kwera.

44 - - Ton coucher de soleil, tu l'auras. Je l'exigerai. Mais j'attendrai, dans ma science du gouvernement, que les conditions soient favorables.

44 - - Rerikú kurí kurasí wapikasawa. Amundú kurí kwá usika. Ma asarú kurí, se muruxawa kwausawa irumu, ara uikú puranga.

45 - - Quand ça sera-t-il? s'informa le petit prince.

45 - - Mairamé taá kwá usika kurí? - upurandú muruxawamirĩ.

46 - - Hem! hem! lui répondit le roi, qui consulta d'abord un gros calendrier, hem! hem! ce sera, vers... vers... ce sera ce soir vers sept heures quarante! Et tu verras comme je suis bien obéi."

46 - - Hum, hum! - usuaxara muruxawa, umaã uikú waá yepé yasí-mukameẽsára turusú retana resé. - Hum, hum! Kurasí wapikasawa usika kurí... usika kurí... kwá pituna, 19: 40 ramé! Remaã kurí kurasí upusú ixé.

47 - Le petit prince bâilla. Il regrettait son coucheur de soleil manqué. Et puis il s'ennuyait déjà un peu:

47 - Aramé muruxawamirĩ uyuíri upirari i yurú. Kurasí wapikasawa uwatari i xupé, asuí aé i piaíwa xinga ana:

48 - “Je n'ai plus rien à faire ici, dit-il au roi. Je vais repartir!

48 - - Ti arikú nẽ maã amunhã arã iké - unheẽ aé muruxawa supé. - Ayuíri kurí awatá!

49 - - Ne pars pas, répondit le roi qui était si fier d'avoir un sujet. Ne pars pas, je te fais ministre!

49 - - Té resú - unheẽ muruxawa, surí uikú waá nhaãsé urikú yepé miasua. - Té resú rẽ, amuyeréu indé se miasua muruxawawara arã!

50 - - Ministre de quoi?

50 - - Maã miasua nungara taá?

51 - - De... de la Justice!

51 - - Satambikasawa supé arã!

52 - - Mais il n'y a personne à juger!

52 - - Ma ti aikwé nẽ awá iké anheẽ arã maã satambika! 
53 - - On ne sait pas, lui dit le roi. Je n'ai pas fait encore le tour de mon royaume. Je suis très vieux, je n'ai pas de place pour un carrosse, et ça me fatigue de marcher.

53 - - Mayé taá rekwáu? - unheẽ muruxawa. - Ti rẽ amaã se retama pawa. Tuyué retana aikú, iké ti mayé arikú yepé muruxawa-siyesara, asuí se kweré apitá mairamé arikuté awatá.

54 - - Oh! Mais j'ai déjà vu, dit le petit prince qui se pencha pour jeter encore un coup d'œil sur l'autre côté de la planète. Il n'y a personne là-bas non plus...

54 - - Oh! Ma ixé amaã ana - unheẽ muruxawamirĩ, umuyeréu waá i akanga amú suaxara kití. - Ti yamaã nẽ awá mimi yuíri...

55 - - Tu te jugeras donc toi-même, lui répondit le roi. C'est le plus difficile. Il est bien plus difficile de se juger soi-même que de juger autrui. Si tu réussis à bien te juger, c'est que tu es un véritable sage.

55 - - Resikari kurí rekwáu mairamé reyawí reikú asuí mairamé satambika reikú unheẽ muruxawa. - Iwasú piri repurungitá suí amú mira-itá resewara. Rekwáu katú ramé indé tẽ resewara, indé supí yepé apigawa kwausawa irumu.

56 - - Moi, dit le petit prince, je puis me juger moi-même n'importe où. Je n'ai pas besoin d'habiter ici.

56 - - Amanduari-kwáu kwá resé mayewa tendawa upé-ntu - unheẽ muruxawamirĩ. Ti arikuté amurari iké sesewara.

57 - - Hem! hem! dit le roi, je crois bien que sur ma planète il y a quelque part un vieux rat. Je l'entends la nuit.

57 - - Ah! - unheẽ muruxawa - amaité tẽ aikwé yepé wawirú tuyué se retama upé. Asendú aé pituna ramé.

58 - Tu pourras juger ce vieux rat. Tu le condamneras à mort de temps en temps. Ainsi, sa vie dépendra de ta justice.

58 - Renheẽ-kwáu kurí maã satambika kwá wawirú resewara. Indé remundúkwáu kurí aé umanũ. Yawé, sikwesawa uikú kurí ne pú resé.

59 - Mais tu le gracieras chaque fois pour l'économiser. Il n'y en a qu'un.

59 - Ma panhẽ mairamé reyerũ kurí aé nhaãsé ti aikwé amú wawirú kwá rupí.

60 - - Moi, répondit le petit prince, je n'aime pas condamner à mort, et je crois bien que je m'en vais.

60 - - Ixé... - usuaxara muruxawamirĩ - ixé ti anheẽ-putari awá urikuté umanũ, kuíri amaité tẽ asú ana.

61 - - Non", dit le roi. 
61 - - Umbaá! - unheẽ muruxawa.

62 - Mais le petit prince, ayant achevé ses préparatifs, ne voulut point peiner le vieux monarque:

62 - Ma muruxawamirĩ, uxari-putari waá nhaã tetama, ti umusasiara-putari nhaã muruxawa tuyué waá:

63 - "Si votre Majesté désirait être obéie ponctuellement, Elle pourrait me donner un ordre raisonable.

63 - - Reputari ramé apusú indé kuíri tẽ, reyururéu-kwáu maã se suí manungara ti waá iwasú.

64 - Elle pourrait m'ordonner, par example, de partir avant une minute. Il me semble que les conditions sont favorables..."

64 - Reyururéu-kwáu se suí asemu kwá suí kuíri tẽ. Amaité ara uikú puranga...

65 - Le roi n'ayant rien répondu, le petit prince hésita d'abord, puis, avec un soupir, prit le départ...

65 - Mayé muruxawa ti unheẽ nẽ maã, muruxawamirĩ usarú xinga, ma kutara nungara uxari nhaã iwaka-retama.

66 - "Je te fais mon ambassadeur", se hâta alors de crier le roi.

66 - - Amuyeréu indé se miasua muruxawawara arã! - aramé tẽ usasemu muruxawa.

67 - Il avait un grand air d'autorité.

67 - Nhaã muruxawa uruyari tẽ aé umundú panhẽ awá resé.

68 - "Les grandes personnes sont bien étranges", se dit le petit prince, en lui-même, durant son voyage.

68 - "Mira-itá turusú amurupí retana", umanduari muruxawamirĩ i watasawa pukusawa.

1 - La seconde planète était habitée par un vaniteux:

1 - Mukũisáwa iwaka-retama upé umurari yepé apigawa warixí.

2 - “Ah! Ah! Voilá la visite d'un admirateur!" s'écria de loin le vaniteux dès qu'il aperçut le petit prince. 
2 - - Ah! Ah! Xukúi yepé mira usaisú umaã waá se resé! - unheẽ apigawa warixí mairamé umaã muruxawamirĩ.

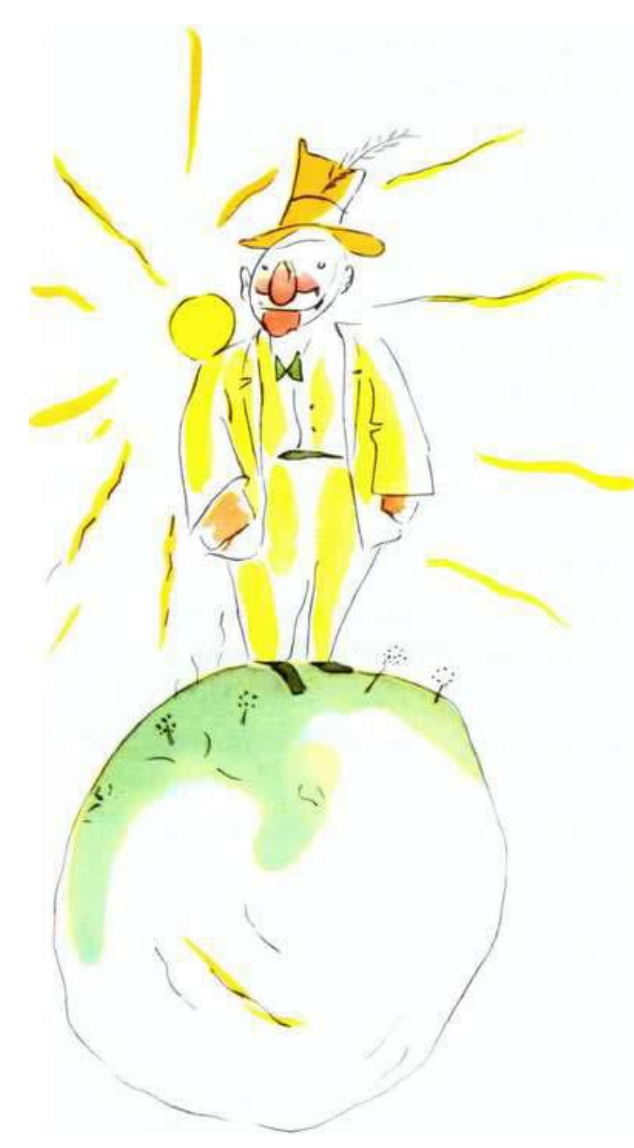

3 - Car, pour les vaniteux, les autres hommes sont des admirateurs.

3 - Apigawa-itá warixí uruyari panhẽ awá usaisú tá umaã aintá resé.

4 - "Bonjour, dit le petit prince. Vous avez un drôle de chapeau.

4 - - Yané ara - unheẽ muruxawamirĩ. - Ne xapewa amurupí tẽ.

5 - - C'est pour saluer, lui répondit le vaniteux. C'est pour saluer quand on m'acclame. Malheureusement il ne passe jamais personne par ici.

5 - - Arikú aé se irumu amukwekatú arã mira-itá. Amusá se xapewa mairamé tá umaã se resé - unheẽ apigawa warixí. Ma nẽ mairamé usasá nẽ awá kwá rupí.

6 - - Ah oui? dit le petit prince qui ne comprit pas.

6 - - Ah, puranga! - unheẽ muruxawamirĩ, ti waá ukwáu nẽ maã.

7 - - Frappe tes mains l'une contre l'autre", conseilla donc le vaniteux.

7 - - Repeteka ne pú-itá yepé amú resé - unheẽ apigawa warixí. 
8 - Le petit prince frappa ses mains l'une contre l'autre. Le vaniteux salua modestement en soulevant son chapeau.

8 - Muruxawamirĩ upeteka i pú-itá yepé amú resé. Aramé apigawa warixí umusá i xapewa umukwekatú arama aé.

9 - "Ça, c'est plus amusant que la visite au roi”, se dit en lui-même le petit prince.

9 - "Iké amurupí piri muruxawa retama suí", muruxawamirĩ umanduari.

10 - Et il recommença de frapper ses mains l'une contre l'autre.

10 - Aramé, aé uyuíri upeteka i pú-itá yepé amú resé.

11 - Le vaniteux recommença de saluer en soulevant son chapeau.

11 - Apigawa warixí umusá i xapewa umukwekatú arama aé amú í.

12 - Après cinq minutes d'exercice le petit prince se fatigua de la monotonie du jeu:

12 - Muruxawamirĩ, upeteka riré i pú-itá yepepú minutu pukusawa, i kweré ana uikú.

13 - "Et, pour que le chapeau tombe, demanda-t-il, que faut-il faire?"

13 - - Indé rexari arã ne xapewa uwari - muruxawamirĩ upurandú -, maã taá arikuté amunhã?

14 - Mais le vaniteux ne l'entendit pas. Les vaniteux n'entendent jamais que les louanges.

14 - Ma apigawa warixí ti usendú aé. Apigawa-itá warixí usendú-ntu mira-itá mairamé tá unheẽ maã-itá puranga aintá resewara.

15 - “Est-ce que tu m'admires vraiment beaucoup? demanda-t-il au petit prince.

15 - - Supí será resaisú remaã-maã se resé? - upurandú aé muruxawamirĩ supé.

16 - - Qu'est-ce que signifie “admirer”?

16 - - Maã taá renheẽ-putari kwá nheenga-itá irumu?

17 - - "Admirer" signifie reconnaître que je suis l'homme le plus beau, le mieux habillé, le plus riche et le plus intelligent de la planète.

17 - - Anheẽ-putari indé remaité ixé apigawa puranga piri, nhaã uyumuamundéu waá puranga piri, apigawa maãsiyara piri asuí kwawara piri kwá tetama upé.

18 - - Mais tu es seul sur ta planète!

18 - - Ma aikwé-ntu indé ne retama upé! 
19 - - Fais-moi ce plaisir. Admire-moi quand même!

19 - - Remusurí ixé. Remaã-maã se resé kwayé tẽ!

20 - - Je t'admire, dit le petit prince, en haussant un peu les épaules, mais en quoi cela peut-il bien t'intéresser?"

20 - - Puranga pá - unheẽ muruxawamirĩ, umaité ana uikú waá nhaã yepé yakwaimasawa. - Ma ti tẽ akwáu mayé kwá umusurí indé!

$21-$ Et le petit prince s'en fut.

21 - Ariré muruxawamirĩ usú ana i suí.

22 - "Les grandes personnes sont décidément bien bizzarres", se dit-il simplement en lui-même durant son voyage.

22 - "Mira-itá turusú amurupí retana tẽ", umanduari muruxawamirĩ i watasawa pukusawa.

12

1 - La planète suivante était habitée par un buveur.

1 - Amú iwaka-retama upé umurari yepé kawera.

2 - Cette visite fut très courte mais elle plongea le petit prince dans une grande mélancolie:

2 - Muruxawamirĩ upitá xinga-ntu mimi, ma kwayé tẽ nhaã tendawa uxari aé sasiara retana.

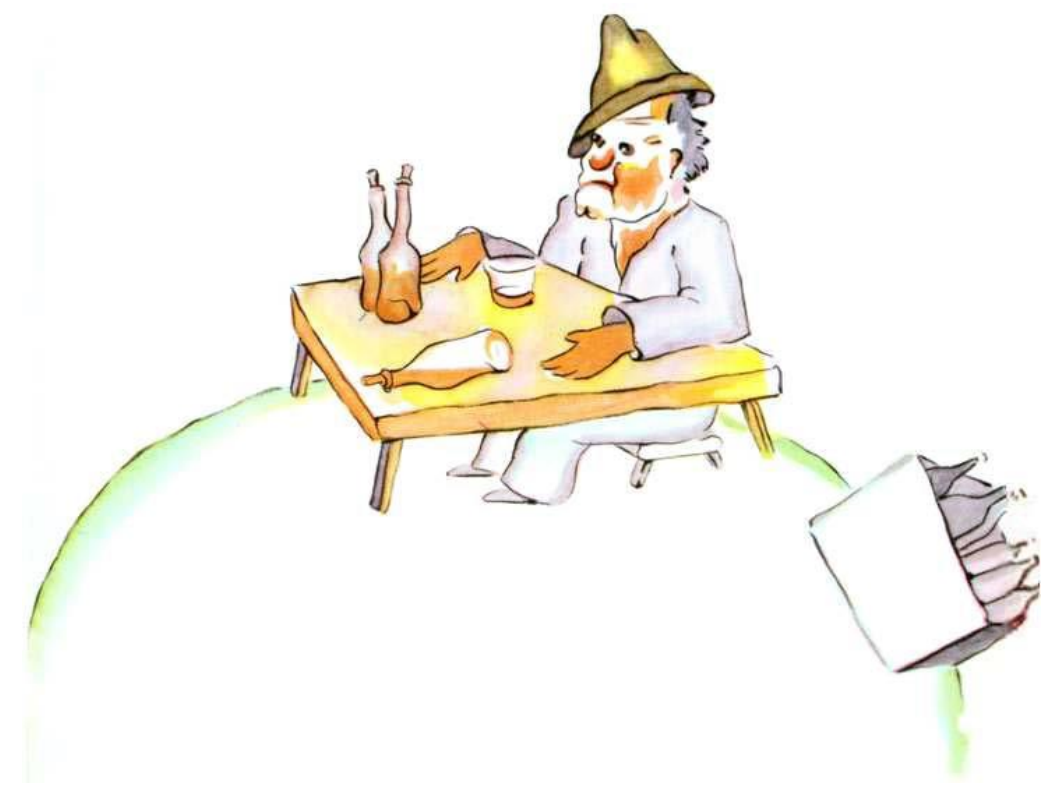


3 - "Que fais-tu là? dit-il au buveur, qu'il trouva installé en silence devant une collection de bouteilles vides et une collection de bouteilles pleines.

3 - - Maá taá remunhã iké? - muruxawamirĩ upurandú kawera suí, ukirirĩ uikú waá kawĩ rirú riía ruakí, yepé-yepé teresemu-íma asuí amu-itá teresemu.

4 - - Je bois, répondit le buveur, d'un air lugubre.

4 - - Akaú - kawera usuaxara sasiara xinga.

5 - - Pourquoi bois-tu? lui demanda le petit prince.

5 - - Marã taá rekaú? - muruxawamirĩ upurandú i suí.

6 - - Pour oublier, répondit le buveur.

6 - - Se resarái arã - usuaxara kawera.

7 - - Pour oublier quoi? s’enquit le petit prince qui déjà le plaignait.

7 - - Maã taá reputari ne resarái? - upurandú muruxawamirĩ, sasiara ana uikú waá sesewara.

8 - - Pour oublier que j'ai honte, avoua le buveur en baissant la tête.

8 - - Se resarái arã asaã tĩsáwa - kawera unheẽ umuyawika i akanga.

9 - - Honte de quoi? s'informa le petit prince qui désirait le secourir.

9 - - Tĩsáwa maã resewara? - upurandú muruxawamirĩ, upitimũ-putari waá aé.

10 - - Honte de boire!” acheva le buveur qui s'enferma définitivement dans le silence.

10 - - Tĩsáwa akaú resewara! - kawera unheẽ, asuí uikuntu amú í.

11 - Et le petit prince s'en fut, perplexe.

11 - Ariré muruxawamirĩ usú rẽ i suí, i akanhemu xinga.

12 - "Les grandes personnes sont décidément très très bizarres", se disait-il en lui-même durant le voyage.

12 - "Mira-itá turusú amurupí retana, tá amurupí retana tẽ", umanduari muruxawamirĩ i watasawa pukusawa. 
1 - La quatrième planète était celle du businessman.

1 - Irundisawa iwaka-retama upé umurari yepé apigawa umunhãwera-ntu waá paparisawa-itá.

2 - Cet homme était si occupé qu'il ne leva même pas la tête à l'arrivée du petit prince.

2 - Mayé nhã̃ apigawa upurakiwera retana, ti umupuamu i akanga mairamé muruxawamirĩ usika.

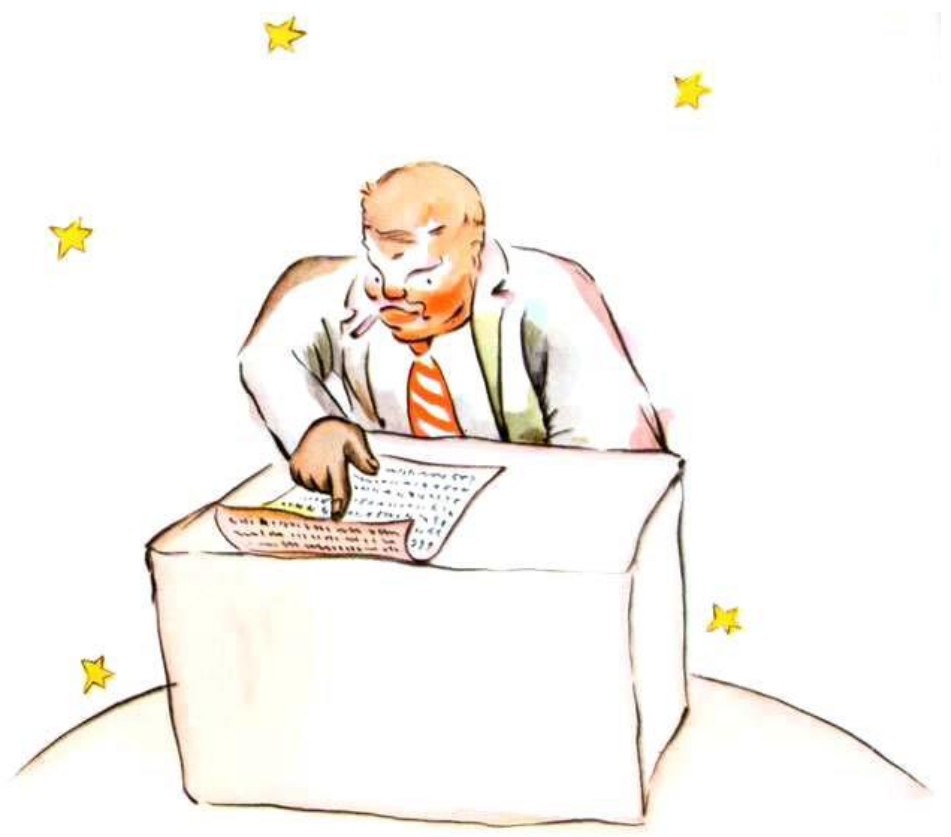

3 - "Bonjour, lui dit celui-ci. Votre cigarette est éteinte.

3 - - Yané ara! - unheẽ muruxawamirĩ. - Ne pitima uwéu uikú.

4 - - Trois et deux font cinq. Cinq et sept douze. Douze et trois quinze. Bonjour. Quinze et sept vingt-deux. Vingt-deux et six vingt-huit. Pas le temps de la rallumer. Vingt-six et cinq trente et un. Ouf! Ça fait donc cinq cent un millions six cent vingt-deux mille sept cent trente et un.

4 - - Musapiri asuí mukũi umunhã yepepú. Yepepú asuí yepepumukũi umunhã mukũipú-mukũi. Mukũipú-mukũi asuí musapiri umunhã musapiripú. Yané ara! Musapiripú asuí yepepumukũi umunhã irundipú-mukũi. Irundipú-mukũi asuí yepepuyepé umunhã irundipú-yepepumusapiri. Ti mayé amundeka aé. Irundipúyepepuyepé asuí yepepú umunhã puyepepú-yepé. Twiante! Aikwé siía, sía, siía...

5 - - Cinq cents millions de quoi?

5 - - Maã taá aikwé sía? 
6 - - Hein? Tu es toujours là? Cinq cent un millions de... je ne sais plus... j'ai tellement de travail! Je suis sérieux, moi, je ne m'amuse pas à des balivernes! Deux et cinq sept...

6 - - Hein? Reikú iké rẽ? Siía, siía, siía... ti ana akwáu, se resarái ana... arikú murakí retana. Ixé yepé apigawa murakisara, ti amanduari tenhuntusawa resé! Mukũi asuí yepepú umunhã yepepumukũi...

7 - - Cinq cent un millions de quoi?" répéta le petit prince qui jamais de sa vie n'avait renoncé à une question, une foi qu'il avait posée.

7 - - Maã taá aikwé siía? - unheẽ amú í muruxawamirĩ, nẽ mairamé uxari waá yepé purandusawa umunhã riré aé.

8 - Le businessman leva la tête:

8 - Aramé nhaã apigawa umupuamu i akanga.

9 - "Depuis cinquante-quatre ans que j'habite cette planète-ci, je n'ai été dérangé que trois fois.

9 - Aikwé mukũipupú-irundí akayú amurari kwá tetama upé, asuí tá umuapatuka-ntu ixé musapiri í.

10 - La première fois ç'a été, il y a vingt-deux ans, par un hanneton qui était tombé dieu sait d'où.

10 - Yepesawa, aikwé ana irundipú-mukũi akayú, yepé arawé nungara resewara uri waá ti akwáu masuí.

11 - Il répandait un bruit épouvantable, et j'ai fait quatre erreurs dans une addition.

11 - Aé umunhã yepé tiapú turusú, sesewara ayawí irundí í paparisawa resé.

12 - La seconde fois ç’a été, il y a onze ans, par une crise de rhumatisme. Je manque d'exercise. Je n'ai pas le temps de flâner. Je suis sérieux, moi.

12 - Mukũisáwa, aikwé ana mukũipú-yepé akayú, mairamé asaã aikú siía sasisawa se pira resé. Ti akataka, ti mayé awatá mirupí. Ixé yepé apigawa murakisara.

13 - La troisième fois... la voici! Je disais donc cinq cent un millions...

13 - Musapirisawa... kuíri tẽ! Yawé, anheẽ aikú, aikwé siía, siía, siía...

14 - - Millions de quoi?"

14 - - Maã taá aikwé siía?

15 - Le businessman comprit qu'il n'était point d'espoir de paix:

15 - Nhaã apigawa umaã ti maã uikuntu-kwáu: 
16 - "Millions de ces petites choses que l'on voit quelquefois dans le ciel.

16 - - Kwá maãmirĩ yamaã waá-itá amuramé iwaka upé.

17 - - Des mouches?

17 - - Merú-itá?

18 - - Mais non, des petites choses qui brillent.

18 - - Umbaá, kwá maãmirĩ uwerá waá-itá.

19 - - Des abeilles?

19 - - Kuisí-itá?

20 - - Mais non. Des petites choses dorées qui font rêvasser les fainéants. Mais je suis sérieux, moi! Je n'ai pas le temps de rêvasser.

20 - - Umbaá. Kwá maãmirĩ-itá werawara umukerpi waá-itá mira-itá yatimamanha. Ma ixé yepé apigawa murakisara! Ti amanduari tenhuntusawa resé.

$21--\mathrm{Ah}$ ! des étoiles?

21 - - Ah! Yasitatá-itá?

22 - - C'est bien ça. Des étoiles.

22 - - Eẽ, yasitatá-itá.

23 - - Et que fais-tu de cinq cents millions d'étoiles?

23 - - Maã taá remunhã siía, sía, siía yasitatá irumu?

24 - - Cinq cent un millions six cent vingt-deux mille sept cent trente et un. Je suis sérieux, moi, je suis précis.

24 - - Aikwé siía, siía, siía yasitatá iwaka upé. Ixé murakisara, apapari tẽ muíri yasitatá.

25 - - Et que fais-tu de ces étoiles?

25 - - Maã taá remunhã kwá-itá yasitatá irumu?

26 - - Ce que j'en fais?

26 - - Maã taá amunhã tá irumu?

27 - - Oui. 
27 - - Eẽ.

28 - - Rien. Je les possède.

28 - - Nẽ maã. Aintá se yara.

29 - - Tu possèdes les étoiles?

29 - - Yasitatá-itá, aintá ne yara?

$30--$ Oui.

30 - - Ẽ̃.

31 - - Mais j'ai déjà vu un roi qui...

31 - - Ma amaã ana yepé muruxawa...

32 - - Les rois ne possèdent pas. Ils "règnent" sur. C'est très différent.

32 - - Muruxawa-itá ti urikú nẽ maã. Aintá umundú panhẽ maã resé, ma nẽ maã tá yara. Kwá amurupí retana.

33 - - Et à quoi cela te sert-il de posséder les étoiles?

33 - - Marã taá puranga indé arã rerikú yasitatá-itá?

34 - - Ça me sert à être riche.

34 - - Aintá umunhã ixé maãsiyara.

35 - - Et à quoi cela te sert-il d'être riche?

35 - - Marã taá puranga indé yepé apigawa maãsiyara?

36 - - À acheter d'autres étoiles, si quelqu'un en trouve."

36 - - Apiripana arã amú-itá yasitatá, amú awá uwasemu ramé aintá.

37 - "Celui-là, se dit en lui-même le petit prince, il raisonne un peu comme mon ivrogne."

37 - "Kwá apigawa”, umanduari muruxawamirĩ, "aé umanduari xinga mayé nhaã kawera yawé."

38 - Cependant il posa encore des questions:

38 - Ma muruxawamirĩ umunhã rẽ amú-itá purandusawa:

39 - "Comment peut-on posséder les étoiles?

39 - - Mayé taá yarikú-kwáu yasitatá-itá? 
40 - - À qui sont-elles? riposta, grincheux, le businessman.

40 - - Awá yara aintá? - apigawa usuaxara i piaíwa.

41 - - Je ne sais pas. À personne.

41 - - Ti akwáu. Aintá nẽ awá yara.

42 - - Alors elles sont à moi, car j’y ai pensé le premier.

42 - - Kwayé, aintá se yara, nhaãsé amanduari kwá resé amú mira-itá renundé.

43 - - Ça suffit?

43 - - Kwá usika?

44 - - Bien sûr. Quand tu trouves un diamant qui n'est à personne, il est à toi. Quand tu trouves une île qui n'est à personne, elle est à toi.

44 - - Eré! Mairamé rewasemu yepé itá-sendí i yara-íma, aé ne yara. Mairamé rewasemu yepé kapuamu i yara-íma, aé ne yara.

45 - Quand tu as une idée le premier, tu la fais breveter: elle est à toi. Et moi je possède les étoiles, puisque jamais personne avant moi n'a songé à les posséder.

45 - Mairamé rerikú yepé manduarisawa amú mira-itá renundé, remupinima aé: aé ne yara. Sesewara yasitatá-itá se iara, nhaãsé nẽ awá se renundé umanduari upitá tá yara mayé se yawé.

46 - - Ça c'est vrai, dit le petit prince. Et qu'en fais-tu?

46 - - Supí - unheẽ muruxawamirĩ. - Maã taá remunhã tá irumu?

47 - - Je les gère. Je les compte et je les recompte, dit le businessman. C'est difficile. Mais je suis un homme sérieux!"

47 - - Amanhana aintá. Apapari aintá siía í - unheẽ nhaã apigawa. - Kwá iwasú, ma ixé yepé apigawa murakisara!

48 - - Le petit prince n'était pas satisfait encore.

48 - - Ma muruxawamirĩ unheẽ-putari rẽ amú maã-itá i xupé.

49 - "Moi, si je possède un foulard, je puis le mettre autour de mon cou et l'emporter. Moi, si je possède une fleur, je puis cueillir ma fleur et l'emporter. Mais tu ne peux pas cueillir les étoiles!

49 - - Ixé, arikú ramé yepé panu pisãwéra, amburi-kwáu aé se ayura resé asuí arasú aé se irumu. Ixé, arikú ramé yepé putira, apuú-kwáu aé asuí arasú aé se irumu. Ma indé ti rerasú-kwáu yasitatá-itá! 
50 - - Non, mais je puis les placer en banque.

50 - - Umbaá, ma amburi-kwáu aintá banku upé.

51 - - Qu'est-ce que ça veut dire?

51 - - Maã taá kwá unheẽ-putari?

52 - - Ça veut dire que j'écris sur un petit papier le nombre de mes étoiles. Et puis j'enferme à clef ce papier-là dans un tiroir.

52 - - Kwá unheẽ-putari amupinima yepé papera pisãwéra resé muíri yasitatá paparisawa arikú waá asuí amburi kwá papera yepé mukaturusara kwara upé.

53 - - Et c'est tout?

53 - - Kwá-ntu?

54 - - Ça suffit!”

54 - - Eẽ.

55 - "C'est amusant, pensa le petit prince. C'est assez poétique. Mais ce n'est pas très sérieux."

55 - "Kwá amurupí retana", umanduari muruxawamirĩ. "Ma yepé murakí tenhuntu."

56 - Le petit prince avait sur les choses sérieuses des idées très différentes des idées des grandes personnes.

56 - Muruxawamirĩ umanduari amurupí mira-itá turusú suí maã-itá resewara aintá umaité waá yepé tenhuntusawa.

57 - "Moi, dit-il encore, je possède une fleur que j'arrose tous les jours. Je possède trois volcans que je ramone toutes les semaines. Car je ramone aussi celui qui est éteint. On ne sait jamais.

57 - - Ixé - unheẽ aé rẽ - arikú yepé putira amururú waá muíri ara. Arikú musapiri iwitepuka ayusí waá muíri sumana. Ayusi yuíri nhaã uwéu uikú waá nhaãsé nẽ mairamé yakwáu maã uyusasá kurí.

58 - C'est utile à mes volcans, et c'est utile à ma fleur, que je les possède. Mais tu n'es pas utile aux étoiles..."

58 - Puranga se iwitepuka-itá supé, se putira supé yuíri, arikú aintá. Ma ti mayé remunhã nẽ maã yasitatá-itá supé...

59 - Le businessman ouvrit la bouche mais ne trouva rien à répondre, et le petit prince s'en fut. 
59 - Aramé, nhaã apigawa umunhãwera-ntu waá paparisawa-itá upirari i yurú ma ti uwasemu nẽ yepé suaxarasawa. Ape, muruxawamirĩ usú ana...

60 - "Les grandes personnes sont décidément tout à fait extraordinaires", se disait-il simplement en lui-même durant le voyage.

60 - "Mira-itá turusú iwasú tẽ", umanduá-duari i watasawa pukusawa.

1 - La cinquième planète était très curieuse. C'était la plus petite de toutes.

1 - Yepepusawa iwaka-retama amurupí retana. Aé mirĩ piri amú-itá suí.

2 - Il y avait là juste assez de place pour loger un réverbère et un allumeur de réverbères.

2 - Nhã̃ tetama upé aikwé-ntu tendawa yepé lamparina supé asuí lamparina mundekasara supé.

3 - Le petit prince ne parvenait pas à s'expliquer à quoi pouvaient servir, quelque part dans le ciel, sur une planète sans maison ni population, un réverbère et un allumeur de réverbères.

3 - Muruxawamirĩ ti ukwáu nhaãsé, iwaka upé, aikwé yepé tetama uka-íma asuí mira-íma, mamé aikwé-ntu yepé lamparina asuí yepé lamparina mundekasara.

4 - Cependant il se dit en lui-même:

4 - Ma umanduari:

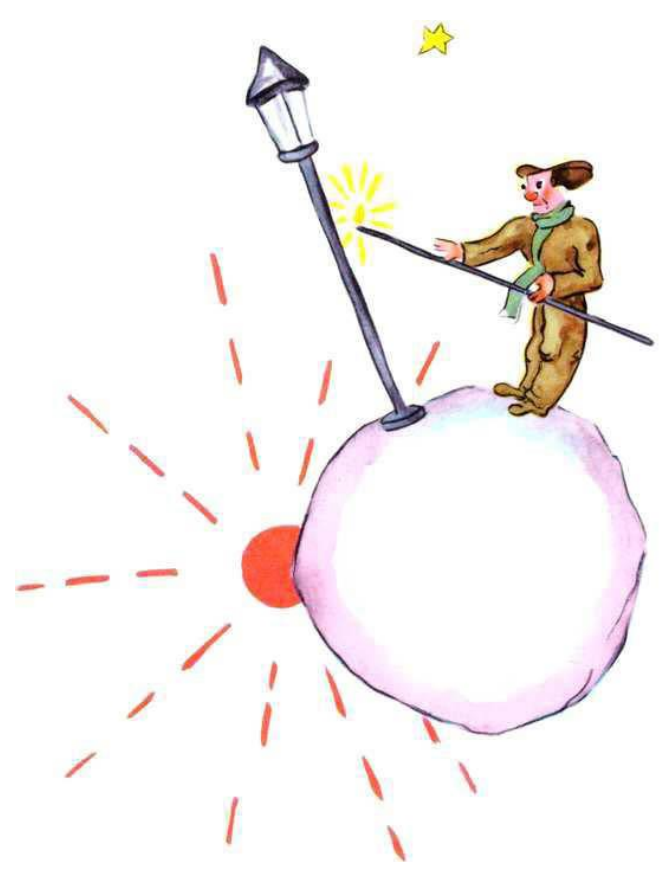


5 - "Peut-être bien que cet homme est absurde. Cependant il est moins absurde que le roi, que le vaniteux, que le businessman et que le buveur.

5 - "Araneíma kwá apigawa yepé yakwaíma. Ma muruxawa, apigawa warixí, apigawa umunhã-ntu waá paparisawa-itá, kawera yuíri, panhẽ aintá yakwaíma piri kwá apigawa suí.

6 - Au moins son travail a-t-il un sens. Quand il allume son réverbère, c'est comme s'il faisait naître une étoile de plus, ou une fleur.

6 - Amurupí amú mira-ítá suí, kwá apigawa murakí puranga amú awá supé. Mairamé umundeka lamparina, nhaã mayé yepé yasitatá uyukwáu ramé maã iwaka upé u mayé yepé putira usemu ramé maã iwí suí.

7 - Quand il éteint son réverbère, ça endort la fleur ou l'étoile. C'est une occupation très jolie. C'est véritablement utile puisque c'est joli."

7 - Ma mairamé umuwéu lamparina, aé umukiri putira u yasitatá. Kwá yepé murakí puranga. Aé puranga nhaãsé upitimũ-kwáu amú awá."

8 - Lorsqu'il aborda la planète, il salua respectueusement l'allumeur:

8 - Mairamé usika nhaã tetama upé, aé umumurã nhaã lamparina mundekasara.

9 - "Bonjour. Pourquoi viens-tu d'éteindre ton réverbère?

9 - - Yané ara. Marã taá remuwéu kuíri tẽ ne lamparina?

10 - - C'est la consigne, répondit l'allumeur. Bonjour.

10 - - Se retama rikusawa resewara - usuaxara mundekasara. - Yané ara.

11 - - Qu'est-ce que la consigne?

11 - - Mayewa taá ne retama rikusawa?

12 - - C'est d'éteindre mon réverbère. Bonsoir."

12 - - Se lamparina muweusawa. Yané pituna.

13 - Et il le ralluma.

13 - Aramé umundeka aé amú í.

14 - "Mais pourquoi viens-tu de le rallumer?

14 - - Marã taá remundeka lamparina amú í?

15 - - C'est la consigne, répondit l'allumeur.

15 - - Se retama rikusawa resewara - usuaxara mundekasara. 
16 - - Je ne comprends pas, dit le petit prince.

16 - - Ixé ti akwáu - unheẽ muruxawamirĩ.

17 - - Il n'y a rien à comprendre, dit l'allumeur. La consigne c'est la consigne. Bonjour."

17 - - Ti aikwé nẽ maã rekwáu arã - unheẽ mundekasara. Arikuté apusú se retama rikusawa. Yané ara.

18 - Et il éteignit son réverbère.

18 - Asuí umuwéu lamparina.

19 - Puis il s'épongea le front avec un mouchoir à carreaux rouges.

19 - Ariré umutikanga i siwá yepé panu piranga irumu.

20 - “Je fais là un métier terrible. C'était raisonnable autrefois. J'éteignais le matin et j'allumais le soir. J'avais le reste du jour pour me reposer, et le reste de la nuit pour dormir...

20 - - Se murakí iwasú retana. Kuxiíma ti kwayé. Amuwéu kwema ramé asuí amundeka pituna ramé. Arikú yepé ara remirera apituú arã asuí pituna remirera akiri arã...

21 - - Et, depuis cette époque, la consigne a changé?

21 - - Asuí, ne retama rikusawa uyumuamurupí?

22 - - La consigne n'a pas changé, dit l'allumeur. C'est bien là le drame! La planète d'année en année a tourné de plus en plus vite, et la consigne n'a pas changé!

22 - - Aé ti uyumuamurupí - unheẽ mundekasara. - Kwá se apatukasawa! Tetama, muíri akayú, uyeréu kutara piri, ma sikusawa ti utirika!

23 - - Alors? dit le petit prince.

23 - - Aramé? - unheẽ muruxawamirĩ.

24 - - Alors maintenant qu'elle fait un tour par minute, je n'ai plus une seconde de repos. J'allume et j'éteins une fois par minute!

24 - - Kuíri, mayé aé uyeréu yepé í muíri minutu, ti apituú-kwáu nẽ mairamé. Amundeka asuí amuwéu yepé í muíri minutu!

25 - - Ça c'est drôle! Les jours chez toi durent une minute!

25 - - Kwá amurupí! Ara-itá iké tá uikupukú yepé minutu! 
26 - - Ce n'est pas drôle du tout, dit l'allumeur. Ça fait déjà un mois que nous parlons ensemble.

26 - - Kwá amurupí tẽ - unheẽ mundekasara. - Aikwé ana yepé yasí yapurungitá yaikú waá.

27 - - Un mois?

27 - - Yepé yasí?

28 - - Oui. Trente minutes. Trente jours! Bonsoir."

28 - - Eẽ. Puyepeyepepú minutu. Puyepeyepepú ara! Yané pituna.

29 - Et il ralluma son réverbère.

29 - Amú í aé umundeka lamparina.

30 - Le petit prince le regarda et il aima cet allumeur qui était tellement fidèle à la consigne.

30 - Muruxawamirĩ usaisú nhaã lamparina mundekasara upusú waá setama rikusawa muíri ara.

31 - Il se souvint des couchers de soleil que lui-même allait autrefois chercher, en tirant sa chaise.

31 - Umanduari kurasí wapikasawa-itá resé umaã-kwáu waá-itá umutirika xinga i wapikawa.

32 - Il voulut aider son ami:

32 - Aramé upitimũ-putari nhaã mundekasara:

33 - "Tu sais... je connais un moyen de te reposer quand tu voudrais...

33 - - Remaã... akwáu mayé repituú-kwáu mairamé indé reputari...

34 - - Je veux toujours", dit l'allumeur.

34 - - Apituú-putari panhẽ mairamé - unheẽ mundekasara.

35 - Car on peut être, à la fois, fidèle et paresseux.

35 - Yandé yakwáu murakisara asuí yatimamanha.

36 - Le petit prince poursuivit:

36 - Muruxawamirĩ unheẽ rẽ: 
37 - "Ta planète est tellement petite que tu en fais le tour en trois enjambées. Tu n'as qu'à marcher assez lentement pour rester toujours au soleil. Quand tu voudras te reposer tu marcheras... et le jour durera aussi longtemps que tu voudras.

37 - - Ne retama kwaíra retana, rerikuté rewatá xinga-ntu ukwáu arã aé pá. Indé rerikuté-ntu rewatá merupí repitá arã kurasí wírupi. Mairamé repituú-putari, indé rewatá kurí... asuí ara uikupukú kurí muíri reputari.

38 - - Ça ne m'avance pas à grand-chose, dit l'allumeur. Ce que j'aime dans la vie, c'est dormir.

38 - - Kwá ti upitimũ retana ixé - unheẽ mundekasara. - Maã asaisú piri waá akirikwáu.

39 - - Ce n'est pas de chance, dit le petit prince.

39 - - Yawé... ti apitimũ-kwáu indé - unheẽ muruxawamirĩ.

40 - - Ce n'est pas de chance, dit l'allumeur. Bonjour."

40 - - Ti mayé - unheẽ mundekasara. - Yané ara.

41 - Et il éteignit son réverbère.

41 - Asuí umuwéu lamparina.

42 - "Celui-là, se dit le petit prince, tandis qu'il poursuivait plus loin son voyage, celuilà serait méprisé par tous les autres, par le roi, par le vaniteux, par le buveur, par le businessman. Cependant c'est le seul qui ne me paraisse pas ridicule. C'est, peut-être, parce qu'il s'occupe d'autre chose que de soi-même."

42 - "Kwá apigawa", umanduari muruxawamirĩ i watasawa pukusawa amú tetama kití, "kwá apigawa maã mutara-íma amú-itá rupí - muruxawa, apigawa warixí, kawera asuí apigawa umunhã-ntu waá paparisawa-itá. Ma aé anhuãté mira ti waá amaité yakwaíma. Araneíma nhaãsé aé umanduari manungara resé amurupí i suí tẽ."

43 - Il eut un soupir de regret et se dit encore:

43 - Asuí aé rẽ unheẽ sasiara xinga:

44 - "Celui-là est le seul dont j'eusse pu faire mon ami. Mais sa planète est vraiment trop petite. Il n'y a pas de place pour deux..."

44 - "Aé anhuãté mira ukwáu maã waá se rumuara. Ma setama kwaíra retana. Ti mayé mukũi mira upitá mimi..."

45 - Ce que le petit prince n'osait pas s'avouer, c'est qu'il regrettait cette planète bénie à cause, surtout, des mille quatre cent quarante couchers de soleil par vingt-quatre heures! 
45 - Muruxawamirĩ ti maã unheẽ-putari aé sasiara uikú uxari resewara nhaã iwaka-retama puranga retana siía, siía, siía kurasí wapikasawa irumu muíri ara.

1 - La sixième planète était une planète dix fois plus vaste. Elle était habitée par un vieux monsieur qui écrivait d'énormes livres.

1 - Puyepesawa iwaka-retama turusú piri retana senundewara suí. Umurari mimi yepé apigawa tuyué umupinima waá papera-itá turusú retana.

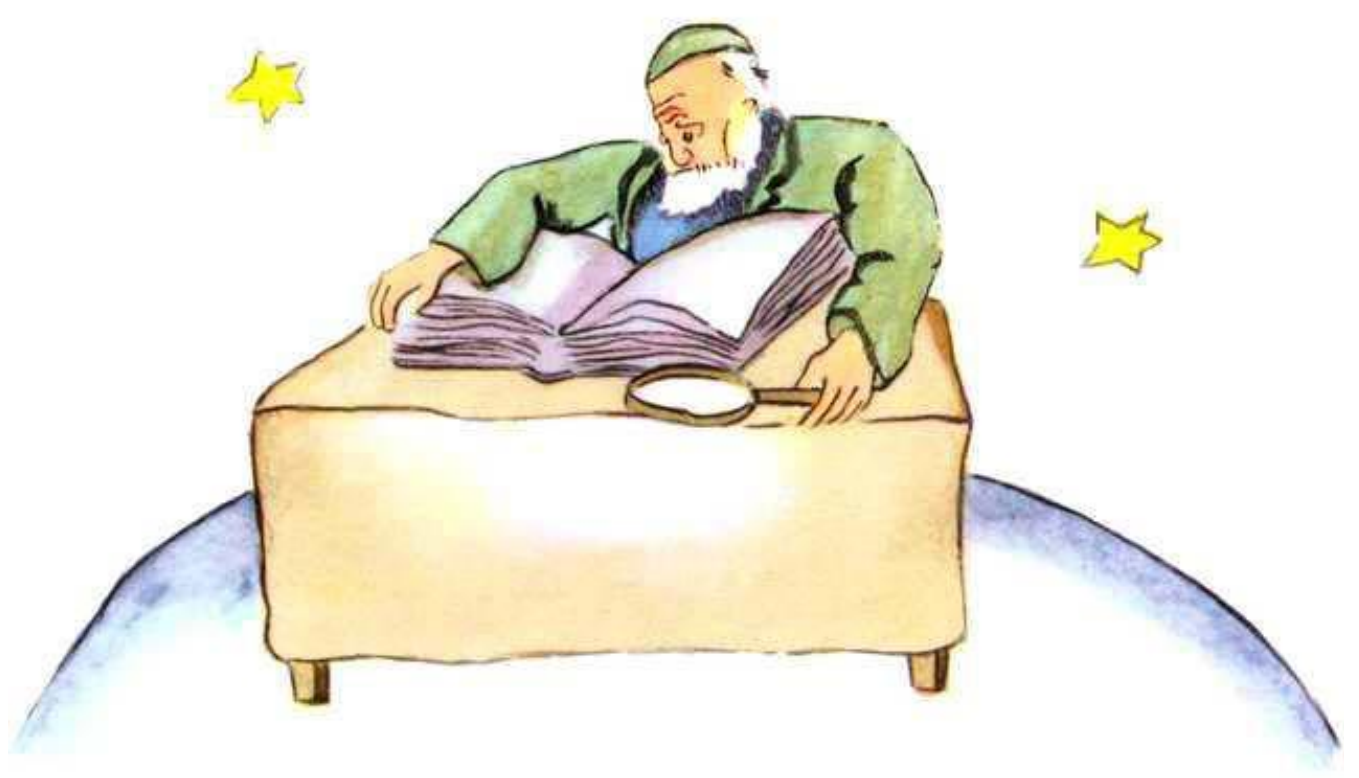

2 - “Tiens! voilà un explorateur!” s'écria-t-il, quand il aperçut le petit prince.

2 - - Pemaã! Xukúi yepé watawera! - unheẽ tuyué mairamé umaã muruxawamirĩ.

3 - Le petit prince s'assit sur la table et souffla un peu. Il avait déjà tant voyagé!

3 - Muruxawamirĩ uwapika nhaãsé aé i kweré. Aé uwatá ana siía tetama rupí!

4 - “D'où viens-tu? lui dit le vieux monsieur.

4 - - Masuí taá reyuri? - upurandú tuyué.

5 - - Quel est ce gros livre? dit le petit prince. Que faites-vous ici?

5 - - Maã taá kwá papera turusú? - unheẽ muruxawamirĩ. - Maã taá remunhã iké?

6 - - Je suis géographe, dit le vieux monsieur.

6 - - Ixé yepé iwí-kwausara - unheẽ tuyué. 
7 - - Qu'est-ce qu'un géographe?

7 - - Maã taá yepé "iwí-kwausara"?

8 - - C'est un savant qui connaît où se trouvent les mers, les fleuves, les villes, les montagnes et les déserts.

8 - - Iwí-kwausara yepé mira ukwáu waá mamé upitá paranãwasú-itá, paranã-itá, tawa-itá, iwitera-itá asuí tetama-itá mira-íma.

9 - - Ça c'est bien intéressant, dit le petit prince. Ça c'est enfin un véritable métier!"

9 - - Kwá amurupí retana - unheẽ muruxawamirĩ. - Kwá yepé murakí supí!

10 - Et il jeta un coup d'œil autour de lui sur la planète du géographe. Il n'avait jamais vu encore une planète aussi majestueuse.

10 - Aramé umaã xinga iwí-kwausara retama. Nẽ mairamé umaã ana yepé iwakaretama turusú piri nhaã suí.

11 - "Elle est bien belle, votre planète. Est-ce qu'il y a des océans?

11 - - Ne retama puranga retana. Aikwé será paranãwasú-itá iké?

12 - - Je ne puis pas le savoir, dit le géographe.

12 - - Ti akwáu - unheẽ iwí-kwausara.

13 - - Ah! (Le petit prince était déçu.) Et des montagnes?

13 - - Ah! (Muruxawamirĩ upitá sasiara.) Aikwé iwitera-itá?

14 - - Je ne puis pas le savoir, dit le géographe.

14 - - Ti akwáu - unheẽ iwí-kwausara.

15 - - Et des villes et des fleuves et des déserts?

15 - - Aikwé tawa-itá, paranã-itá, tetama-itá mira-íma?

16 - - Je ne puis pas le savoir non plus, dit le géographe.

16 - - Ti akwáu yuíri - unheẽ, amú í, iwí-kwausara.

17 - - Mais vous êtes géographe!

17 - - Ma indé yepé iwí-kwausara!

18 - - C'est exact, dit le géographe, mais je ne suis pas explorateur. Je manque absolument d'explorateurs. Ce n'est pas le géographe qui va faire le compte de villes, des fleuves, des montagnes, des mers, des océans et des déserts. Le géographe est trop 
important pour flâner. Il ne quitte pas son bureau. Mais il y reçoit les explorateurs. Il les interroge, et il prend en note leurs souvenirs. Et si les souvenirs de l'un d'entre eux lui paraissent intéressants, le géographe fait faire une enquête sur la moralité de l'explorateur.

18 - - Supí! - unheẽ iwí-kwausara. - Ma ixé ti watawera. Uwatari watawera-itá upitimũ arã ixé. Ti iwí-kwausara awá usú upapari tawa-itá, paranã-itá, iwitera-itá, paranãwasú-itá, tetama-itá mira-íma. Ti iwí-kwausara murakí uwatá-watá mirupí. Iwí-kwausara nẽ mairamé uxari i papera-itá. Ma aé upurungitá watawera-itá irumu, upurandú siía maã aintá suí asuí umupinima maã aintá unheẽ tá watasawaitá resewara. Mairamé yepé iwí-kwausara usendú manungara amurupí, aé upurandú siía maã watawera suí, umaã arã sa nhaã aé umbeú waá ti será yepé puité.

19 - - Pourquoi ça?

19 - - Marã taá?

20 - - Parce qu'un explorateur qui mentirait entraînerait des catastrophes dans les livres de géographie. Et aussi un explorateur qui boirait trop.

20 - - Nhaãsé yepé watawera umbeú ramé maã puité-itá, aé umuaíwa maã iwíkwausawa papera-itá, mayé yepé watawera kawera yawé.

21 - - Pourquoi ça? fit le petit prince.

21 - - Marã taá? - upurandú muruxawamirĩ.

22 - - Parce que les ivrognes voient double. Alors le géographe noterait deux montagnes, là où il n'y en a qu'une seule.

22 - - Nhaãsé kawera-itá ti umaã puranga. Sesewara iwí-kwausara umupinima maã aikwé mukũi iwitera mamé, supí, aikwé yepé-ntu iwitera.

23 - - Je connais quelqu'un, dit le petit prince, qui serait mauvais explorateur.

23 - - Akwáu yepé mira aé maã waá yepé watawera puxiwera - unheẽ muruxawamirĩ.

24 - - C'est possible. Donc, quand la moralité de l'explorateur parait bonne, on fait une enquête sur sa découverte.

24 - Araneíma indé rekwáu tẽ. Ma, mairamé iwí-kwausara umaité yepé watawera ti unheẽ puité-itá, siía purandusawa uyumunhã i wasemusawa resewara.

25 - - On va voir?

25 - - Asuí iwí-kwausara usú umaã wasemusawa? 
26 - - Non. C'est trop compliqué. Mais on exige de l'explorateur qu'il fournisse des preuves. S'il s'agit par exemple de la découverte d'une grosse montagne, on exige qu'il en rapporte de grosses pierres."

26 - - Umbaá. Kwá iwasú retana. Ma watawera urikuté umukameẽ sangawa-itá. Watawera umbeú ramé uwasemu yepé iwitera turusú, aé urikuté ururi yepé-yepé itá turusú ixé arã.

27 - Le géographe soudain s'émut.

27 - Aramé iwí-kwausara uyumusurí:

28 - "Mais toi, tu viens de loin! Tu es explorateur! Tu vas me décrire ta planète!"

28 - - Ma indé... indé reyuri apekatú suí! Indé yepé watawera! Aputari rembeú ixé arã ne retama resewara!

29 - Et le géographe, ayant ouvert son registre, tailla son crayon. On note d'abord au crayon les récits des explorateurs. On attend, pour noter à l'encre, que l'explorateur ait fourni des preuves.

29 - Aramé iwí-kwausara, upirari riré yepé papera turusú, umusakapira i pinimasara rupiara. Yamupinima yepé pinimasara rupiara pupé maã wataweraitá unheẽ yandé arã. Ariré yasarú watawera-itá ururi sangawa-itá yapawa arama yané murakí.

30 - “Alors? interrogea le géographe.

30 - - Aramé? - upurandú iwí-kwausara.

31 - - Oh! chez moi, dit le petit prince, ce n'est pas très intéressant, c'est tout petit. J'ai trois volcans. Deux volcans en activité, et un volcan éteint. Mais on ne sait jamais.

31 - - Oh! Mamé amurari - unheẽ muruxawamirĩ - ti aikwé siía maã, se retama kwaíra retana. Arikú musapiri iwitepuka. Mukũi iwitepuka upuka rẽ waá asuí yepé uwéu uikú waá. Nẽ mairamé yakwáu maã uyusasá kurí...

32 - - On ne sait jamais, dit le géographe.

32 - - Nẽ mairamé yakwáu maã uyusasá kurí... - unheẽ iwí-kwausara.

33 - - J'ai aussi une fleur.

33 - - Arikú yuíri yepé putira.

34 - - Nous ne notons pas les fleurs, dit le géographe.

34 - - Iwí-kwausara-itá ti umupinima putira-itá resewara - unheẽ iwí-kwausara.

35 - - Pourquoi ça! c'est les plus joli! 
35 - - Marã taá? Aintá puranga retana!

36 - - Parce que les fleurs sont éphémères.

36 - - Nhaãsé putira-itá susanga-íma.

37 - - Qu'est-ce que signifie: "éphémère”?

37 - - Maã taá "susanga-íma"?

38 - - Les géographies, dit le géographe, sont les livres les plus sérieux de tous les livres. Elles ne se démodent jamais. Il est très rare qu'une montagne change de place. Il est très rare qu'un océan se vide de son eau. Nous écrivons des choses éternelles.

38 - - Iwí-kwausawa papera-itá - unheẽ iwí-kwausara - tá unheẽ-ntu supisawa. Nẽ mairamé tá upitá tuyué. Iwasú retana yepé iwitera ukataka. Iwasú retana yepé paranãwasú utikanga. Yamupinima maã-itá resewara nẽ mairamé umanũ waá-itá.

39 - - Mais les volcans éteints peuvent se réveiller, interrompit le petit prince. Qu'est-ce que signifie: "éphémère"?

39 - - Ma iwitepuka-itá uwéu uikú waá tá uyuíri-kwáu tá upuka amú í - unheẽ muruxawamirĩ. - Maã taá "susanga-íma"?

40 - - Que les volcans soient éteints ou soient éveillés, ça revient au même pour nous autres, dit le géographe. Ce qui compte pour nous, c'est la montagne. Elle ne change pas.

40 - - Iwitepuka-itá uwéu uikú ramé u tá upuka ramé, yandé arã yepewasú pawa unheẽ iwí-kwausara. - Yamupinima iwitera-itá resewara. Aintá nẽ mairamé ukataka.

41 - - Mais qu'est-ce que signifie “éphémère"? répéta le petit prince qui, de sa vie, n'avait renoncé à une question, une fois qu'il l'avait posée.

41 - - Ma... maã taá "susanga-íma"? - unheẽ amú í muruxawamirĩ, nẽ mairamé sesarái waá yepé purandusawa suí.

42 - - Ça signifie "qui est menacé de disparition prochaine".

42 - - Aintá ukanhemu-kwáu kutara nungara.

43 - - Ma fleur est menacée de disparition prochaine?

43 - - Se putira ukanhemu-kwáu kutara nungara?

44 - - Bien sûr."

44 - - Ẽ̃. 
45 - "Ma fleur est éphémère, se dit le petit prince, et elle n'a que quatre épines pour se défendre contre le monde! Et je l'ai laissée toute seule chez moi!"

45 - “Araneíma se putira umanũ kurí”, umanduari muruxawamirĩ, "aé urikú-ntu irundí yú uyupisirũ arã asuí ixé axari aé yepenhũ se retama upé!"

46 - Ce fut là son premier mouvement de regret. Mais il reprit courage:

46 - Sesewara muruxawamirĩ uyumusasiara. Ma, kutara nungara, upitá katú yuíri:

47 - “Que me conseillez-vous d'aller visiter? demanda-t-il.

47 - - Maã iwaka-retama indé remungitá ixé akwáu arã? - upurandú aé.

48 - - La planète Terre, lui répondit le géographe. Elle a une bonne réputation..."

48 - - Tetama sera waá Iwí - usuaxara iwí-kwausara. Kwá iwaka-retama serakwena retana.

49 - Et le petit prince s'en fut, songeant à sa fleur.

49 - Aramé muruxawamirĩ usú ana, umanduari i putira resé.

1 - La septième planète fut donc la Terre.

1 - Pumukũisáwa iwaka-retama muruxawamirĩ ukwáu waá uyuseruka Iwí.

2 - La Terre n'est pas une planète quelconque! On y compte cent onze rois (en n'oubliant pas, bien sûr, les rois nègres), sept mille géographes, neuf cent mille businessmen, sept millions et demi d'ivrognes, trois cent onze millions de vaniteux, c'est-à-dire environ deux milliards de grandes personnes.

2 - Iwí ti yepé tetama mayé amú-itá yawé! Iwí upé aikwé siía muruxawa kariwa asuí tapayuna, siía iwí-kwausara, siía apigawa umunhã-ntu waá paparisawa-itá, siía kawera, siía apigawa warixí - yawé, aikwé kwá tetama upé siía, siía, siía mira turusú.

3 - Pour vous donner une idée des dimensions de la Terre je vous dirai qu'avant l'invention de l'électricité on y devait entretenir, sur l'ensemble des six continents, une véritable armée de quatre cent soixante deux mille cinq cent onze allumeurs de réverbères.

3 - Pekwáu arama Iwí turususawa resewara, anheẽ penhẽ arama itirisitati munhangawa renundé yepé lamparina mundekasara riía urikuté umundeka tá lamparina-itá umuturí arama panhẽ Iwí retama. 
4 - Vu d'un peu loin ça faisait un effet splendide. Les mouvements de cette armée étaient réglés comme ceux d'un ballet d'opéra. D'abord venait le tour des allumeurs de réverbères de Nouvelle-Zélande et d'Australie.

4 - Mairamé yaikú apekatú lamparina-itá sendí suí, aintá upitá rẽ puranga piri. Mundekasara riía katakasawa-itá mayé yepé purasisawa yawé. Yepesawa mundekasara-itá Nova Zelândia, Austrália suiwara.

5 - Puis ceux-ci, ayant allumé leurs lampions, s'en allaient dormir. Alors entraient à leur tour dans la danse les allumeurs de réverbères de Chine et de Sibérie. Puis eux aussi s'escamotaient dans les coulisses.

5 - Kwá-itá, tá umundeka riré tá lamparina-itá, tá usú tá ukiri. Asuí mundekasara-itá China, Sibéria suiwara yuíri tá uwiké nhaã purasisawa kití. Aramé, tá upawa riré tá murakí, tá usú tá upituú yuíri.

6 - Alors venait le tour des allumeurs de réverbères de Russie et des Indes. Puis de ceux d'Afrique et d'Europe. Puis de ceux d'Amérique du Sud. Puis de ceux d'Amérique du Nord. Et jamais ils ne se trompaient dans leur ordre d'entrée em scène. C'était grandiose.

6 - Ariré xinga tá uyukwáu mundekasara Rússia, Índia suiwara. Asuí, mundekasara-itá África, Europa suiwara. Ariré, mundekasara-itá América-itá suiwara. Aintá nẽ mairaré uyawí mairamé tá uwiké purasisawa kití. Nhaã puranga retana!

7 - Seuls, l'allumeur de l'unique réverbère du pôle Nord, et son confrère de l'unique réverbère du pôle Sud, menaient des vies d'oisiveté et de nonchalance: ils travaillaient deux fois par an.

7 - Mukũi-ntu mundekasara - mundekasara Polo-itá suiwara - tá upurakí xinga. Aikwé-ntu yepé lamparina muíri Polo upé. Kwá-itá mundekasara urasú yepé sikwesawa yatimamanha nhaãsé tá upurakí-ntu mukũi í muíri akayú ramé.

1 - Quand on veut faire de l'esprit, il arrive que l'on mente un peu. Je n'ai pas été très honnête en vous parlant des allumeurs de réverbères.

1 - Mairamé yamunhã-munhã-putari, amuramé yapuitemunhã xinga. Ti anhẽ̃ supisawa pawa mairamé ambeú lamparina mundekasara-itá resewara.

2 - Je risque de donner une fausse idée de notre planète à ceux qui ne la connaissent pas. Les hommes occupent très peu de place sur la Terre.

2 - Araneíma mira ti waá-itá ukwáu Iwí ti tá ukwáu maã anheẽ aikú waá. Mira-itá uikú, supí, kwaíra Iwí rendawa upé. 
3 - Si les deux milliards d'habitants qui peuplent la Terre se tenaient debout et un peu serrés, comme pour un meeting, ils logeraient aisément sur une place publique de vingt milles de long sur vingt milles de large.

3 - Panhẽ mira umurari waá Iwí upé tá upuamu ramé maã asuí tá upitá maã yepewasú amú-itá ruaxara mayé yepé wayurí nungara yawé, panhẽ aintá upitákwáu maã yepé tawa turusú upé.

4 - On pourrait entasser l'humanité sur le moindre petit îlot du Pacifique.

4 - Yamburi-kwáu maã panhẽ mira Pacífico kapuamu kwaíra piri upé.

5 - Les grandes personnes, bien sûr, ne vous croiront pas. Elles s'imaginent tenir beaucoup de place. Elles se voient importantes comme des baobabs.

5 - Mira-itá turusú, supí, ti tá uruyari kurí kwá nheenga-itá resé. Aintá umaité tá uikú siía tendawa upé. Aintá umanduari tá turusú mayé baobá-itá yawé.

6 - Vous leur conseillerez donc de faire le calcul. Elles adorent les chiffres: ça leur plaira. Mais ne perdez pas votre temps à ce pensum. C'est inutile. Vous avez confiance en moi.

6 - Peyururéu tá suí tá umunhã yepé-yepé paparisawa. Aintá usaisú paparisawa, yawé tá surí upitá kurí. Ma té pemanduá-duari retana kwá resé, kwá yepé tenhuntusawa. Akwáu peruyari se resé!

7 - Le petit prince, une fois sur Terre, fut donc bien surpris de ne voir personne. Il avait déjà peur de s'être trompé de planète, quand un anneau couleur de lune remua dans le sable.

7 - Muruxawamirĩ i akanhemu mairamé usika Iwí upé, nhaãsé aé ti usuantí nẽ awá. Aé umaité tẽ araneíma uikú maã amú iwaka-retama upé, mairamé umaã manungara ukataka iwikuí upé.

8 - "Bonne nuit, fit le petit prince à tout hasard.

8 - - Yané pituna - unheẽ muruxawamirĩ.

9 - - Bonne nuit, fit le serpent.

9 - - Yané pituna - usuaxara buya.

10 - - Sur quelle planète suis-je tombé? demanda le petit prince.

10 - - Mamé taá aikú? - upurandú muruxawamirĩ.

11 - - Sur la Terre, en Afrique, répondit le serpent.

11 - - Iwí upé, África upé - usuaxara buya. 


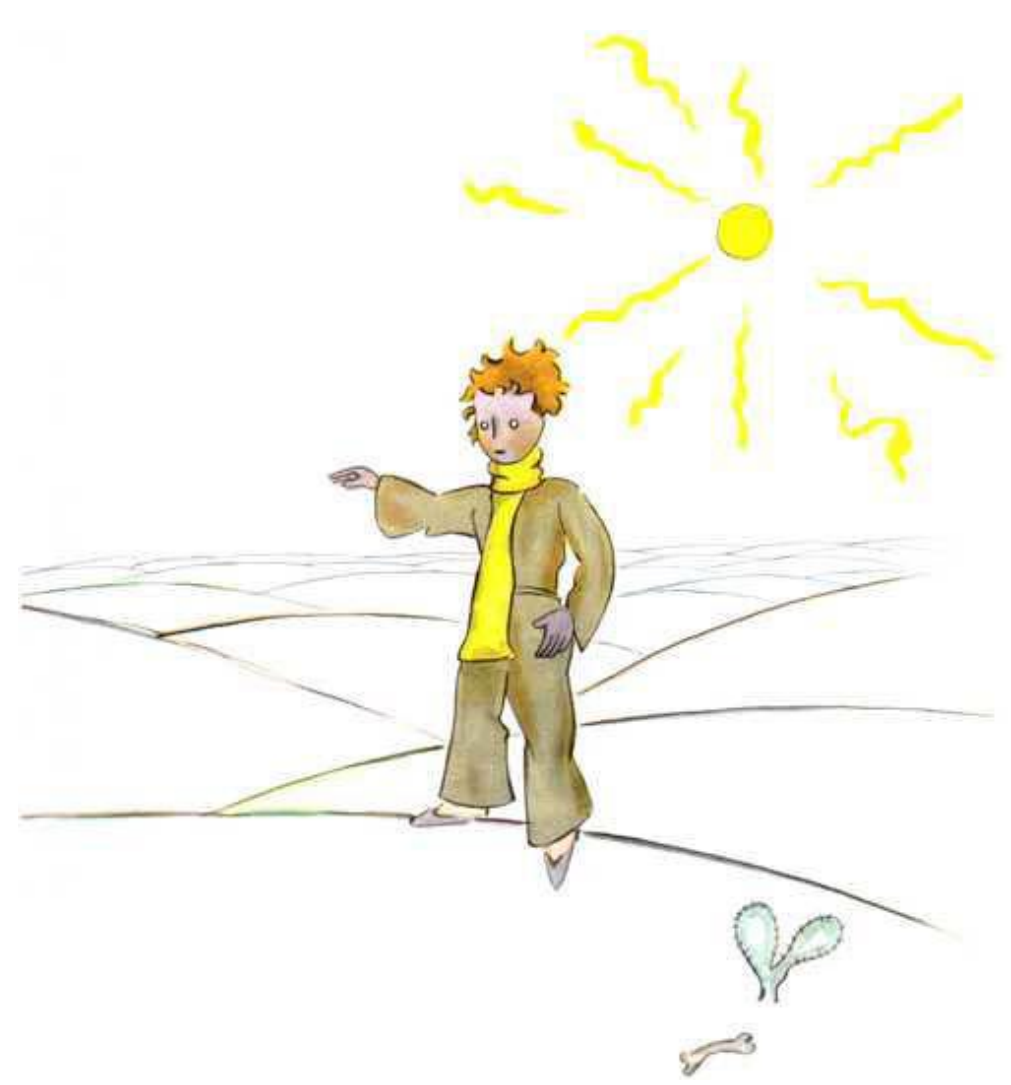

12 - - Ah!... Il n'y a donc personne sur la Terre?

12 - - Ah!... Ti yamaã nẽ awá Iwí upé?

13 - - Ici c'est le désert. Il n'y a personne dans les déserts. La Terre est grande", dit le serpent.

13 - - Yaikú yepé tetama mira-íma upé. Ti yamaã nẽ awá tetama-itá mira-íma upé. Iwí turusú - unheẽ buya.

14 - Le petit prince s'assit sur une pierre et leva les yeux vers le ciel:

14 - Muruxawamirĩ uwapika yepé itá resé, asuí umupuamu sesá-itá iwaka kití:

15 - "Je me demande, dit-il, si les étoiles sont éclairées afin que chacun puisse un jour retrouver la sienne. Regarde ma planète. Elle est juste au-dessus de nous... Mais comme elle est loin!

15 - - Apurandú se suí tẽ sa yasitatá-itá uwerá iwaka upé muíri mira uwasemu arã i yara. Remaã se iwaka-retama. Aé uikú yané árupi... Ma uikú apekatú retana kwá suí!

16 - - Elle est belle, dit le serpent. Que viens-tu faire ici?

16 - - Aé puranga - unheẽ buya. - Maã taá indé reyuri remunhã iké?

17 - - J'ai des difficultés avec une fleur, dit le petit prince. 
17 - - Arikú yepé-yepé iwasusawa yepé putira irumu - unheẽ muruxawamirĩ.

18 - - Ah!” fit le serpent.

18 - - Ah! - unheẽ buya.

$19-$ Et ils se turent.

19 - Aintá ukirirĩ.

20 - "Où sont les hommes? reprit enfin le petit prince. On est un peu seul dans le désert...

20 - - Mamé taá uikú mira-itá? - upurandú amú í muruxawamirĩ. - Yayusaã yepenhũ xinga yepé tetama mira-íma upé...

21 - - On est seul aussi chez les hommes", dit le serpent.

21 - - Mira-itá pitérupi yayusaã yepenhũ yuíri - unheẽ buya.

22 - Le petit prince le regarda longtemps:

22 - Muruxawamirĩ umaã-maã nhaã buya resé:

23 - "Tu es une drôle de bête, lui dit-il enfin, mince comme un doigt...

23 - - Indé yepé suú amurupí - unheẽ aé. - Indé puĩ mayé se pú-rakapira yawé...

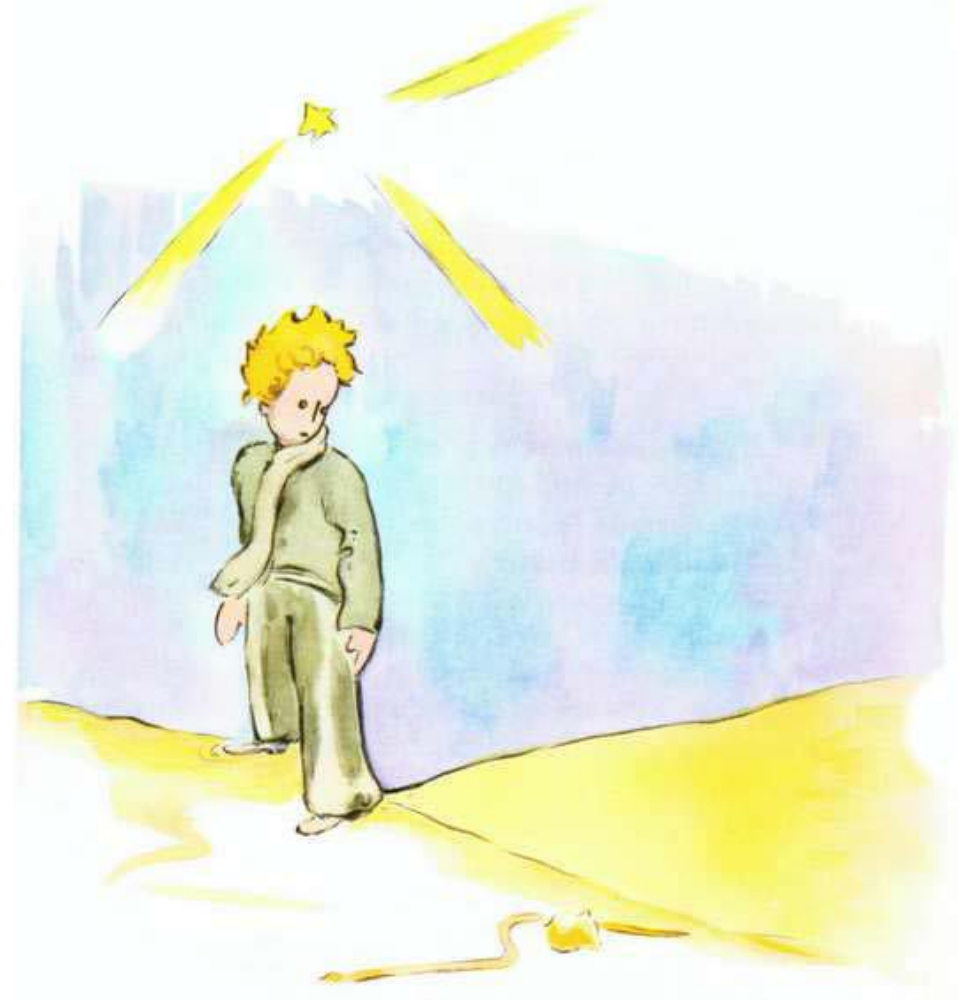


24 - - Mais je suis plus puissant que le doigt d'un roi", dit le serpent.

24 - - Ma ixé kirimbawa piri yepé muruxawa pú-rakapira suí - unheẽ buya.

25 - Le petit prince eut un sourire:

25 - Aramé muruxawamirĩ upuká xinga:

26 - “Tu n'es pas bien puissant... tu n'as même pas de pattes... tu ne peux même pas voyager...

26 - - Indé ti tẽ kirimbawa retana... ti rerikú ne pú, ne pí... ti rewatá-kwáu yuíri...

27 - - Je puis t'emporter plus loin qu'un navire", dit le serpent.

27 - - Arasú-kwáu indé apekatú piri yepé igarité suí - unheẽ buya.

28 - Il s'enroula autour de la cheville du petit prince, comme un bracelet d'or:

28 - Aé uyumamana muruxawamirĩ retimã resé mayé yepé mupurangawa itátawá suiwara yawé.

29 - "Celui que je touche, je le rends à la terre dont il est sorti, dit-il encore. Mais tu es pur et tu viens d'une étoile..."

29 - - Mairamé ayumamana yepé mira resé, amundú aé tetama kití masuí uri unheẽ buya. - Ma ne piá katú asuí akwáu reyuri yepé yasitatá suí...

30 - Le petit prince ne répondit rien.

30 - Muruxawamirĩ ti usuaxara nẽ maã.

31 - "Tu me fais pitié, toi si faible, sur cette Terre de granit. Je puis t'aider un jour si tu regrettes trop ta planète. Je puis...

31 - - Apitá sasiara ne rupí, indé kwairamirĩ, kwá tetama upé itá suiwara. Apitimũ-kwáu indé yepé ara, mairamé ne retama uwatari indé arã. Akwáu...

32 - - Oh! J'ai très bien compris, fit le petit prince, mais pourquoi parles-tu toujours par énigmes?

32 - - Oh! Amaã puranga maã renheẽ-putari waá - unheẽ muruxawamirĩ. - Ma marã taá renheẽ nheenga-itá rupí uyumimi waá-itá maã renheẽ-putari waá?

33 - - Je les résous toutes", dit le serpent.

33 - - Akwáu puranga maã nheenga-itá uyumimi - unheẽ buya.

$35-$ Et ils se turent.

35 - Aramé aintá ukirirĩ. 
1 - Le petit prince traversa le désert et ne rencontra qu'une fleur. Une fleur à trois pétales, une fleur de rien du tout...

1 - Muruxawamirĩ uyasá nhaã tetama mira-íma ma uwasemu yepé-ntu putira. Yepé putira musapiri putira-rawa irumu, yepé putiramirĩ mayé amú-itá yawé...

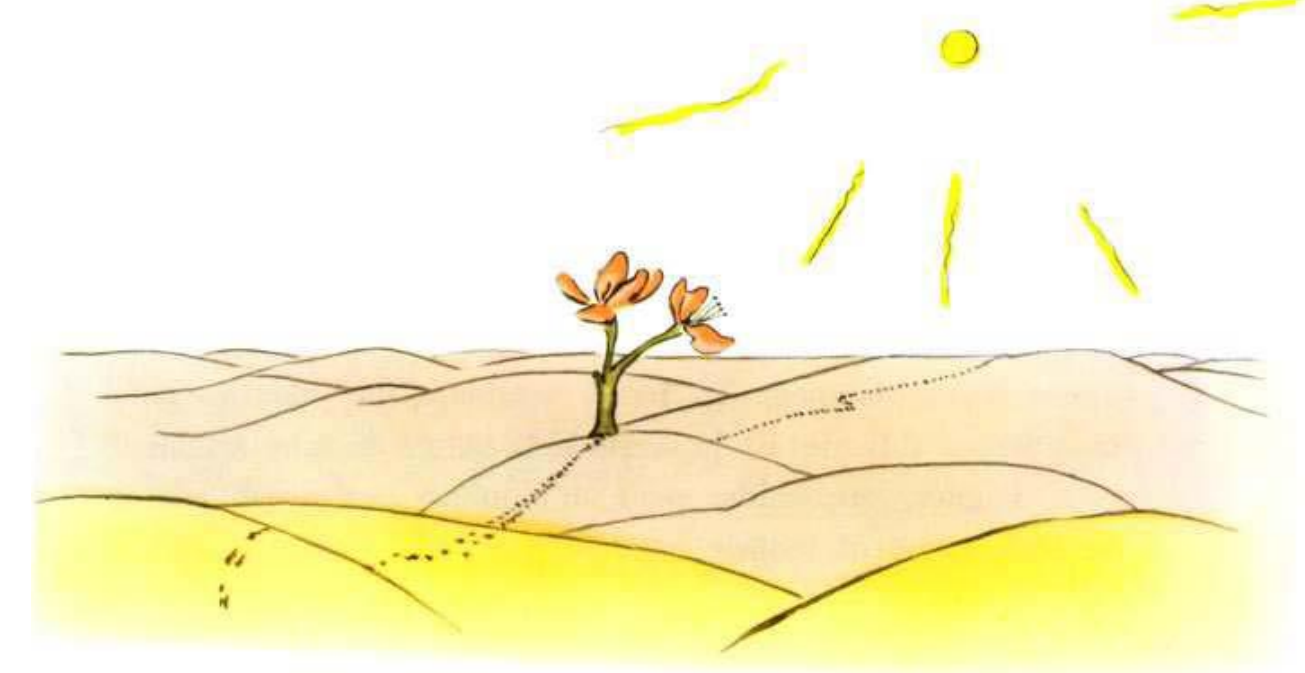

2 - "Bonjour, dit le petit prince.

2 - - Yané ara - unheẽ muruxawamirĩ.

3 - - Bonjour, dit la fleur.

3 - - Yané ara - unheẽ putira.

4 - - Où sont les hommes?" demanda poliment le petit prince.

4 - - Indé rekwáu mamé mira-itá uikú? - upurandú muruxawamirĩ.

5 - La fleur, un jour, avait vu passer une caravane:

5 - Nhaã putira, yepé ara, umaã ana usasá yepé miratiwa:

6 - "Les hommes? Il en existe, je crois, six ou sept. Je les ai aperçus il y a des années. Mais on ne sait jamais où les trouver. Le vent les promène. Ils manquent de racines, ça les gêne beaucoup.

6 - - Mira-itá? Amaité aikwé puyepé u pumukũi. Aikwé ana siía akayú ixé amaã yepé mira. Nẽ mairamé yakwáu mamé aintá uikú. Iwitú urasú aintá. Aintá ti urikú tá rapú, sesewara iwasú yamaã aintá. 
7 - - Adieu, fit le petit prince.

7 - - Té kurimirĩ - unheẽ muruxawamirĩ.

8 - - Adieu", dit la fleur.

8 - - Té kurimirĩ - unheẽ putira.

1 - Le petit prince fit l'ascencion d'une haute montagne.

1 - Muruxawamirĩ uyupiri yepé iwitera iwaté.

2 - Les seules montagnes qu'il eût jamais connues étaient les trois volcans qui lui arrivaient au genou.

2 - Aé ukwáu-ntu iwitera-itá urikú waá senipiã iwatesawa mayé musapiri iwitepuka setama suiwara yawé.

3 - Et il se servait du volcan éteint comme d'un tabouret.

3 - Muruxawamirĩ supé, iwitepuka uwéu uikú waá mayé wapikawamirĩ yawé.

4 - 'D'une montagne haute comme celle-ci, se dit-il donc, j'apercevrai d'un coup toute la planète et tous les hommes..."

4 - "Yepé iwitera iwaté árupi mayé nhaã yawé", umanduari muruxawamirĩ, "amaã kurí Iwí pawa asuí panhẽ mira..."

5 - Mais il n'aperçut rien que des aiguilles de roc bien aiguisées.

5 - Ma umaã-ntu itá sakapirawara mayé awí-itá yawé. 


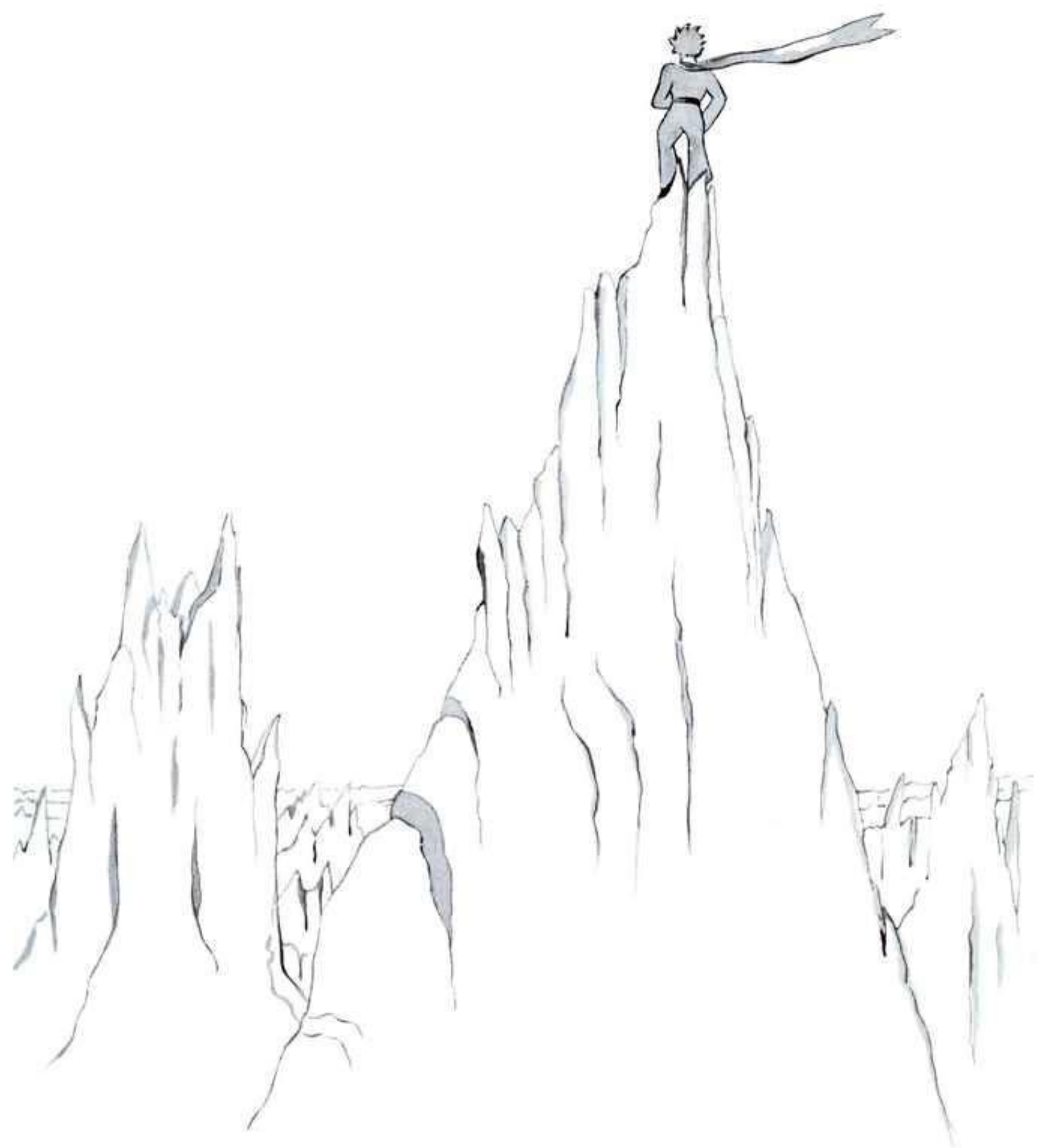

6 - "Bonjour, dit-il à tout hasard.

6 - - Yané ara - unheẽ aé tenhuntu.

7 - - Bonjour... Bonjour... Bonjour..., répondit l'écho.

7 - - Yané ara... Yané ara... Yané ara... - usuaxara itá-nheenga.

8 - - Qui êtes-vous? dit le petit prince. 
8 - - Awá taá indé? - unheẽ muruxawamirĩ.

9 - - Qui êtes-vous... qui êtes-vous... qui êtes-vous..., répondit l'écho.

9 - - Awá taá indé... awá taá indé... awá taá indé... - usuaxara itá-nheenga.

10 - - Soyez mes amis, je suis seul, dit-il.

10 - - Aputari penhẽ se rumuara-itá arama, anhuíra aikú... - unheẽ aé.

11 - - Je suis seul... je suis seul... je suis seul...", répondit l'écho.

11 - - Anhuíra aikú... anhuíra aikú... anhuíra aikú... - usuaxara itá-nheenga.

12 - "Quelle drôle de planète! pensa-t-il alors. Elle est toute sèche, et toute pointue et toute salée. Et les hommes manquent d'imagination.

12 - "Kwá tetama amurupí retana!", umanduari aramé. "Iké tikangawara pá, sakapirawara pá, yukirawara pá. Asuí mira-itá umanduariwara mayé amú-itá yawé.

13 - Ils répètent ce qu'on leur dit... Chez moi j'avais une fleur: elle parlait toujours la première..."

13 - Aintá nẽ mairamé unheẽ manungara amurupí... Se retama upé arikú yepé putira: panhẽ mairamé aé upurungitá se renundé.

1 - Mais il arriva que le petit prince, ayant longtemps marché à travers les sables, les rocs et les neiges, découvrit enfin une route.

1 - Ma muruxawamirĩ, uwatá retana riré iwikuí rapé-itá rupí, itá rapé-itá rupí asuí tendawa-itá irusanga rupí, aé uwasemu yepé pewasú.

2 - Et les routes vont toutes chez les hommes.

2 - Pewasú-itá, panhẽ aintá usika té mira-itá.

3 - "Bonjour", dit-il.

3 - - Yané ara! - unheẽ aé.

4 -C'était un jardin fleuri de roses.

4 - Aikwé ape yepé putira-itá piranga riía.

5 - - "Bonjour", dirent les roses. 
5 - - Yané ara! - unheẽ putira-itá piranga.

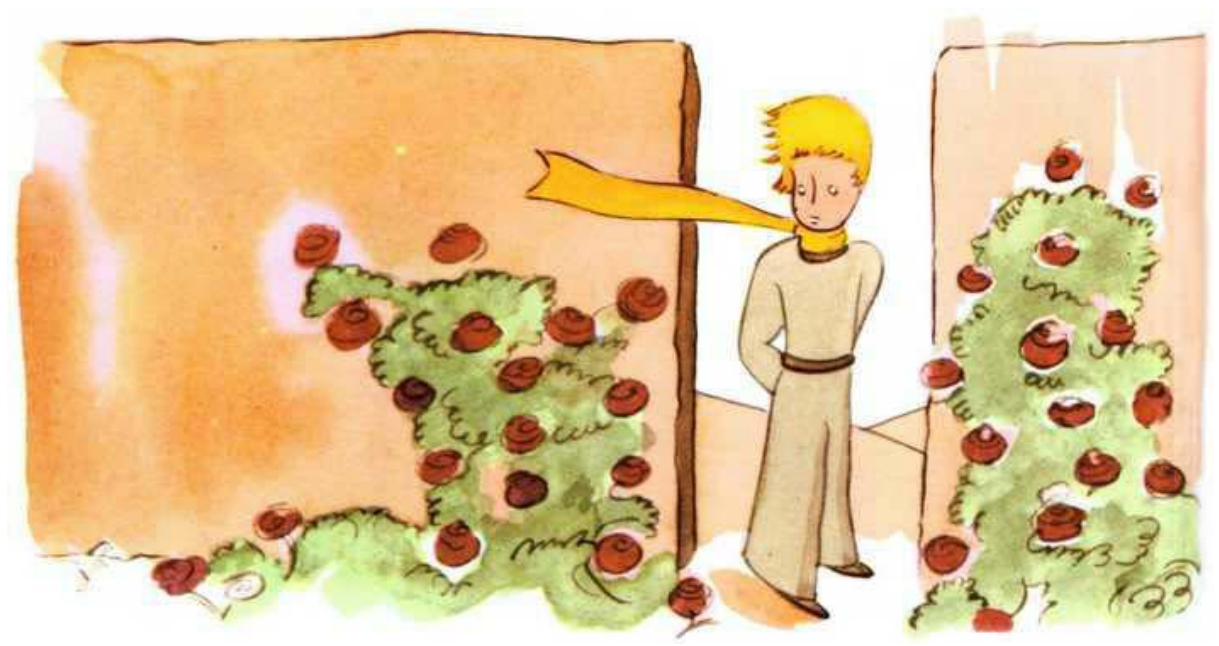

6 - Le petit prince les regarda. Elles ressemblaient toutes à sa fleur.

6 - Muruxawamirĩ umaã aintá resé. Panhẽ aintá mayé i putira yawé.

7 - “Qui êtes-vous? leur demanda-t-il, stupéfait.

7 - Awá taá penhẽ? - upurandú aé i akanhemu.

8 - - Nous sommes des roses, dirent les roses.

8 - - Yandé putira-itá piranga - usuaxara aintá.

$9--$ Ah!” fit le petit prince...

9 - - Ah! - unheẽ muruxawamirĩ.

10 - Et il se sentit très malheureux. Sa fleur lui avait raconté qu'elle était seule de son espèce dans l'univers.

10 - Aé upitá sasiara retana. I putira unheẽ i xupé aé yepé putira amurupí panhẽ suí.

11 - Et voici qu'il en était cinq mille, toutes semblables, dans un seul jardin!

11 - Ma aé umaã, nhã̃ putiratiwa upé-ntu, siía putira mayé i yara yawé. 


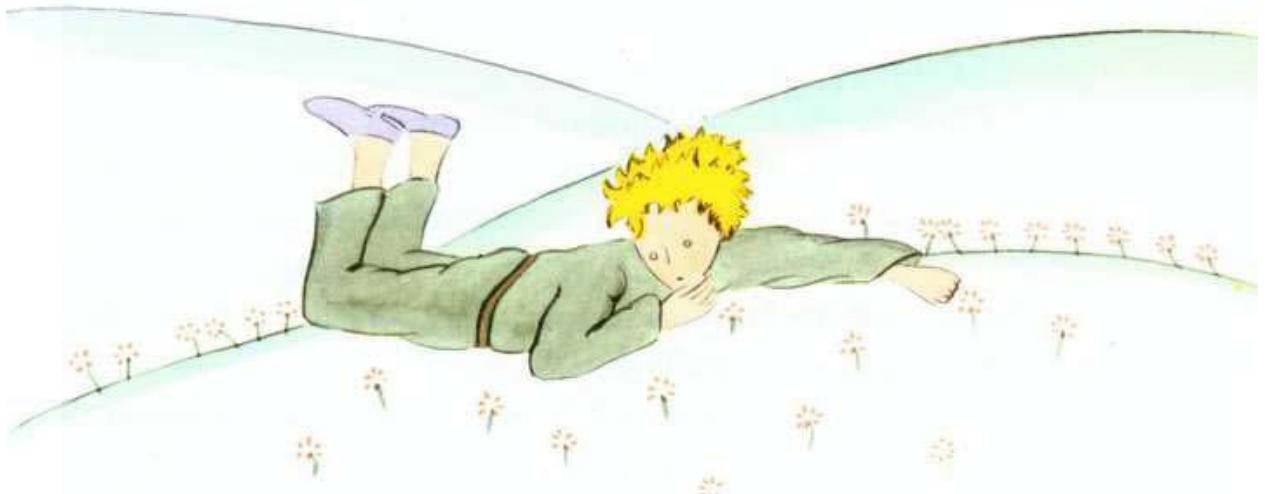

12 - "Elle serait bien vexée, se dit-il, si elle voyait ça... elle tousserait énormément et ferait semblant de mourir pour échapper au ridicule.

12 - "Se putira upitá maã tĩsáwa irumu", umanduari aé, "aé umaã ramé maã kwa putira-itá... aramé utusé maã asuí unheẽ maã aé umanũ ana uikú ti arã-ntu uyumaã tĩsáwa retana irumu.

13 - Et je serais bien obligé de faire semblant de la soigner, car, sinon, pour m'humilier moi aussi, elle se laisserait vraiment mourir..."

13 - Sesewara arikuté maã apisirũ aé, nhaãsé araneíma aé umanũ-putari maã supí umumirĩ arã-ntu ixé.

14 - Puis il se dit encore: "Je me croyais riche d'une fleur unique, et je ne possède qu'une rose ordinaire. Ça et mes trois volcans qui m'arrivent au genou, et dont l'un, peut-être, est éteint pour toujours, ça ne fait pas de moi un bien grand prince..."

14 - Ariré umanduari rẽ: "Se rurí kwera arikú yepé putira resewara amurupí amú-itá suí, ma maã arikú supí yepé putira mayé amú-itá yawé. Yepé putira asuí musapiri iwitepuka urikú waá se renipiã iwatesawa, asuí araneíma yepé iwitepuka-itá suí ti kurí uyuíri upuka amú í. Kwá maã-itá ti umuyeréu ixé yepé muruxawa supí arã..."

15 - Et, couché dans l'herbe, il pleura.

17 - Asuí, aé uyaxiú uyenũ kapiĩ resé.

1 - C'est alors qu'apparut le renard:

1 - Ariré xinga uyukwáu yepé yawara kaapura: 


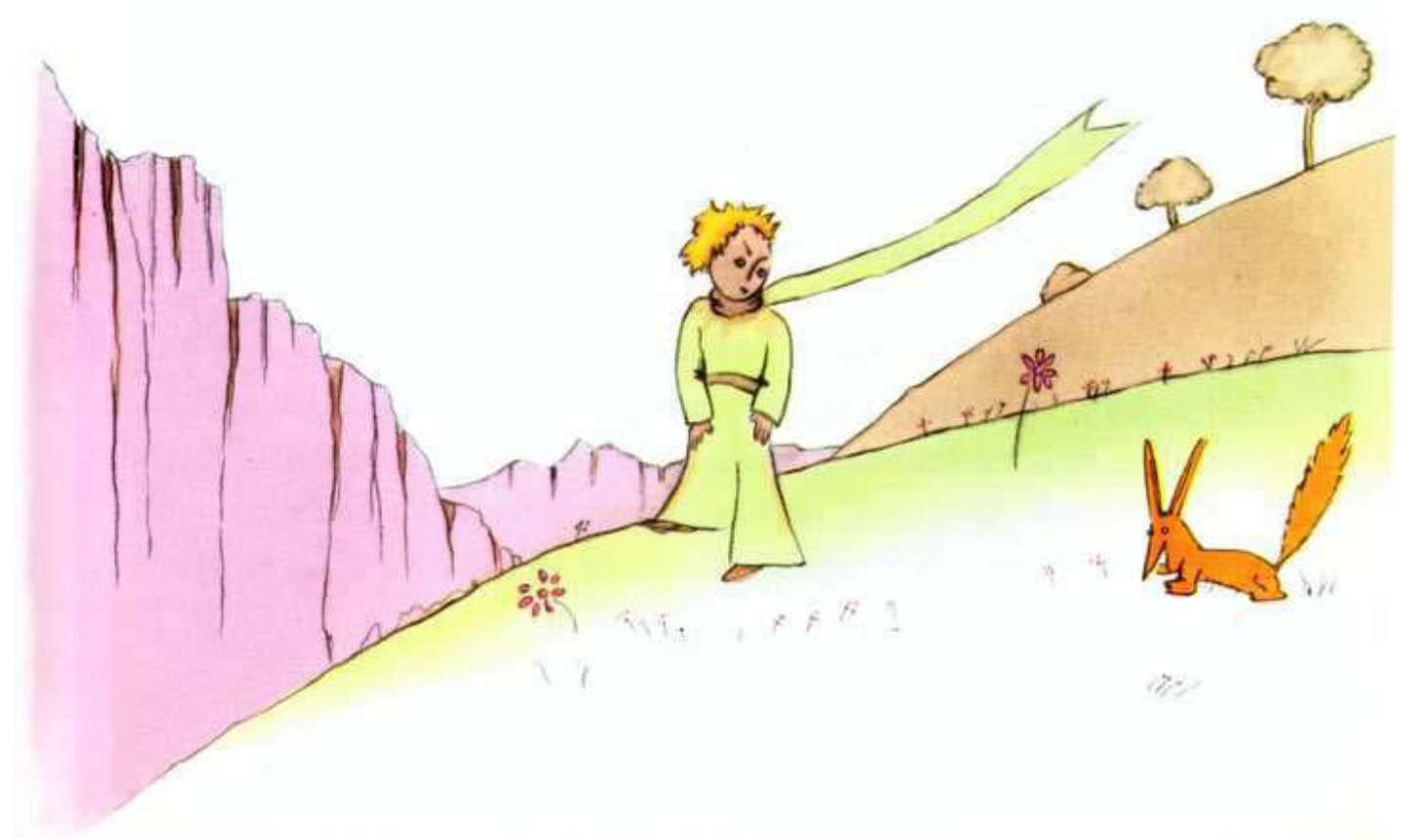

2 - "Bonjour, dit le renard.

2 - - Yané ara - unheẽ yawara kaapura.

3 - - Bonjour, répondit poliment le petit prince, qui se retourna mais ne vit rien.

3 - - Yané ara - usuaxara muruxawamirĩ, uyeréu waá amú suaxara kití ma ti umaã nẽ maã.

4 - - Je suis là, dit la voix, sous le pommier...

4 - - Aikú iké - unheẽ nheenga - kumãíwa wírupi...

5 - - Qui es-tu? dit le petit prince. Tu es bien joli...

5 - - Awá taá indé? - unheẽ muruxawamirĩ. - Indé puranga retana...

6 - - Je suis un renard, dit le renard.

6 - - Ixé yepé yawara kaapura - unheẽ aé.

7 - - Viens jouer avec moi, lui proposa le petit prince. Je suis tellement triste...

7 - - Reyuri remusarái se irumu - unheẽ muruxawamirĩ. - Sasiara retana aikú...

8 - - Je ne puis pas jouer avec toi, dit le renard. Je ne suis pas apprivoisé.

8 - - Ti amusarai-kwáu ne irumu - unheẽ yawara kaapura. - Indé ti rẽ reyusá se piá.

9 - - Ah! pardon", fit le petit prince. 
9 - - Ah! Reyerũ ixé - unheẽ muruxawamirĩ.

10 - Mais, après réflexion, il ajouta:

10 - Ma, umanduari xinga riré, aé umuapiri:

11 - “Qu'est-ce que signifie ‘apprivoiser'?”

11 - - Maã taá renheẽ-putari kwá nheenga-itá irumu?

12 - - Tu n'es pas d'ici, dit le renard, que cherches-tu?

12 - - Indé ti ikewara - unheẽ yawara kaapura. Maã taá resikari reikú?

13 - - Je cherche les hommes, dit le petit prince. Qu'est-ce que signifie “apprivoiser”?

13 - - Asikari mira-itá - unheẽ muruxawamirĩ. - Maã taá indé renheẽ-putari nhaã nheenga-itá irumu?

14 - - Les hommes, dit le renard, ils ont des fusils et ils chassent. C'est bien gênant! Ils élèvent aussi des poules. C'est leur seul intérêt. Tu cherches des poules?

14 - - Mira-itá - unheẽ yawara kaapura - tá urikú mukawa asuí tá ukamundú. Kwá umusikié! Tá umimbáu sapukaya yuíri. Anhuãté maã puranga tá umunhã waá. Resikari será sapukaya-itá?

15 - - Non, dit le petit prince. Je cherche des amis. Qu'est-ce que signifie “apprivoiser”?

15 - - Umbaá - unheẽ muruxawamirĩ. - Akwáu-putari mira-itá. - Maã taá indé renheẽ-putari nhaã nheenga-itá irumu?

16 - - C'est une chose trop oubliée, dit le renard. Ça signifie "créer des liens...".

16 - - Nhaã nheenga-itá umukameẽ manungara siía mira tá resarái ana waá unheẽ yawara kaapura. - Aintá irumu, anheẽ-putari ti rẽ yarikú nẽ yepé yusana nungara umuapiri waá yandé.

17 - - Créer des liens?

17 - - "Yepé yusana nungara umuapiri waá yandé”?

18 - - Bien sûr, dit le renard. Tu n'es encore pour moi qu'un petit garçon tout semblable à cent mille petits garçons. Et je n'ai pas besoin de toi. Et tu n'as pas besoin de moi non plus. Je ne suis pour toi qu'un renard semblable à cent mille renards. Mais, si tu m'apprivoises, nous aurons besoin l'un de l'autre. Tu seras pour moi unique au monde. Je serai pour toi unique au monde...

18 - - Yawé tẽ - unheẽ yawara kaapura. - Indé ti rẽ ixé arã yepé kurumĩ amurupí amú-itá suí. Ixé ti rẽ awatari indé arã, indé yuíri ti rẽ rewatari ixé arã. Ixé rẽ indé arã yepé yawara kaapura mayé amú-itá yawé. Ma, reyusá ramé se piá, yawatari 
kurí amú supé. Yawé indé kurí ixé arã amurupí amú-itá kurumĩ suí, ixé kurí indé arã amurupí amú-itá yawara kaapura suí...

19 - - Je commence à comprendre, dit le petit prince. Il y a une fleur... je crois qu'elle m'a apprivoisé...

19 - - Amaité akwáu kuíri - unheẽ muruxawamirĩ. - Aikwé yepé putira... amaité aé uyusá ana se piá...

20 - - C'est possible, dit le renard. On voit sur la Terre toutes sortes de choses...

20 - - Araneíma kwá supisawa - unheẽ yawara kaapura. - Yamaã tẽ siía maã Iwí upé...

21 - - Oh! ce n'est pas sur la Terre", dit le petit prince.

21 - - Oh! Kwá ti uyusasá Iwí upé - unheẽ muruxawamirĩ.

22 - Le renard parut très intrigué:

22 - Aramé yawara kaapura umanduá-duari:

23 - "Sur une autre planète?

23 - - Amú iwaka-retama upé?

$24-$ - Oui.

24 - - Eẽ.

25 - - Il y a des chasseurs, sur cette planète-là?

25 - - Aikwé kamundusara-itá kwá tetama upé?

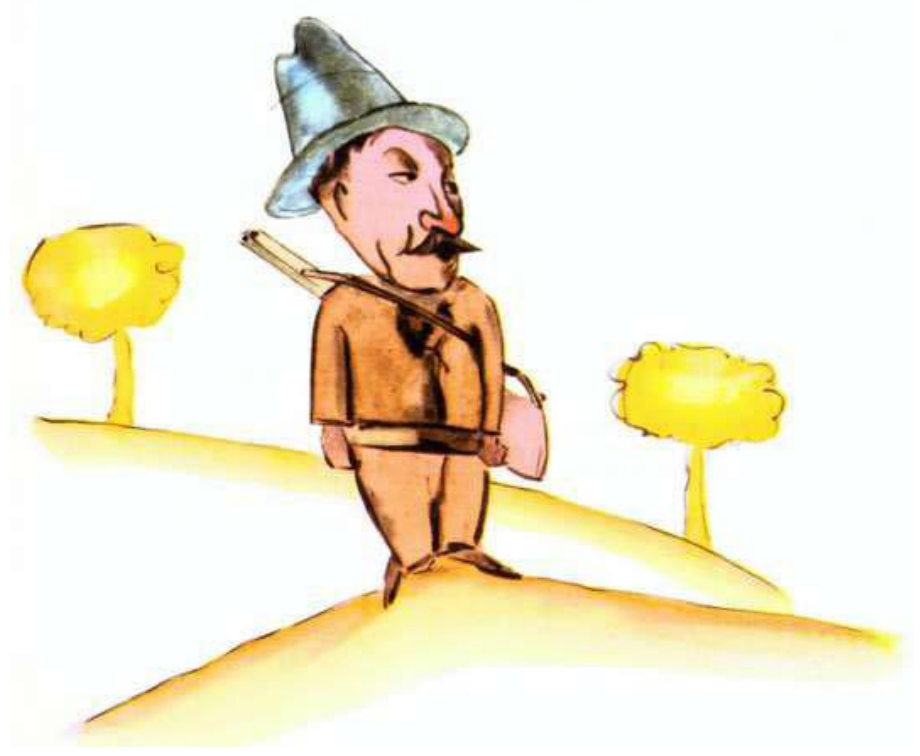


$26--$ Non.

26 - - Umbaá.

27 - - Ça, c'est intéressant! Et des poules?

27 - - Kwá puranga retana! Aikwé sapukaya-itá?

28 - - Non.

28 - - Umbaá.

29 - - Rien n'est parfait", soupira le renard.

29 - - Nẽ pawa puranga retana - unheẽ yawara kaapura.

30 - Mais le renard revint à son idée:

30 - Ariré xinga yawara kaapura unheẽ rẽ:

31 - "Ma vie est monotone. Je chasse les poules, les hommes me chassent. Toutes les poules se ressemblent, et tous les hommes se ressemblent.

31 - - Ixé arã, panhẽ ara yepewasú pawa. Akamundú sapukaya-itá, mira-itá ukamundú ixé. Panhẽ sapukaya tá yepewasú, panhẽ mira tá yepewasú yuíri.

32 - Je m'ennuie donc un peu. Mais, si tu m'apprivoises, ma vie sera comme ensoleillée.

32 - Kwá umusasiara xinga ixé. Ma, reyusá ramé se piá, panhẽ ara kurí ixé arã mayé yepé ara kurasiwara yawé.

33 - Je connaîtrai un bruit de pas qui sera différent de tous les autres. Les autres pas me font rentrer sous terre. Le tien m'appellera hors du terrier, comme une musique.

33 - Akwáu kurí tiapú ne pirusawa suí, aé kurí amurupí amú-itá suí. Amú pirusawa-itá umuwiké ixé iwí kwara upé. Ma, ne pirusawa-itá usenũi kurí ixé mayé yepé nheengarisawa yawé, asuí ixé asemu kurí se kwara suí.

34 - Et puis regarde! Tu vois, là-bas, les champs de blé? Je ne mange pas de pain. Le blé pour moi est inutile. Les champs de blé ne me rappellent rien.

34 - Asuí, remaã! Indé remaã-kwáu apekatú kwá suí awatí kupixawa-itá? Ti ambaú miapé. Ixé arã awatí ti puranga. Awatí kupixawa-itá, ti tá umumanduari ixé nẽ maã resé.

35 - Et ça, c'est triste! Mais tu as des cheveux couleur d'or. Alors ce sera merveilleux quand tu m'auras apprivoisé!

35 - Kwá umusasiara ixé! Ma ne awa pinimasawa itá-tawá nungara. Aramé, puranga retana kurí mairamé indé reyusá se piá! 
36 - Le blé, qui est doré, me fera souvenir de toi. Et j'aimerai le bruit du vent dans le blé..."

36 - Awatí rawa, tawá waá, umumanduari kurí ixé ne resé. Asaisú kurí tiapú awatí rawa umunhã waá mairamé iwitú upeyú...

37 - Le renard se tut et regarda longtemps le petit prince:

37 - Yawara kaapura ukirirĩ asuí umaã-maã muruxawamirĩ resé:

38 - "S'il te plaît... apprivoise-moi! dit-il.

38 - - Ayururéu ne suí... reyusá se piá! - unheẽ yawara kaapura.

39 - - Je veux bien, répondit le petit prince, mais je n'ai pas beaucoup de temps. J'ai des amis à découvrir et beaucoup de choses à connaître.

39 - - Puranga maã - unheẽ muruxawamirĩ -, ma ti aikupukú-kwáu iké. Uwatari rẽ awasemu mira-itá asuí amaã siía maã.

40 - - On ne connaît que les choses que l'on apprivoise, dit le renard. Les hommes n'ont plus le temps de rien connaître. Ils achètent des choses toutes faites chez les marchands. Mais comme il n'existe point de marchands d'amis, les hommes n'ont plus d'amis. Si tu veux un ami, apprivoise-moi!

40 - - Yakwáu katú nhaã-ntu yamukaturú waá yané piá kwara upé - unheẽ yawara kaapura. - Uií ara mira-itá ti ana tá ukwáu nẽ maã katú reté. Aintá upiripana pá piripanasawa ruka-itá upé. Ma, mayé ti yamaã piripanasawa rukaitá uvenderi waá mira-itá, ti ana tá urikú aintá rumuara. Reputari ramé ixé ne rumuara arã, reyusá se piá!

41 - - Que faut-il faire? dit le petit prince.

41 - - Maã taá arikuté amunhã? - unheẽ muruxawamirĩ.

42 - - Il faut être très patient, répondit le renard. Tu t'assoiras d'abord un peu loin de moi, comme ça, dans l'herbe. Je te regarderai du coin de l'œil et tu ne diras rien. Le langage est source de malentendus. Mais, chaque jour, tu pourras t'asseoir un peu plus près..."

42 - - Rerikuté resarú - usuaxara yawara kaapura. - Rewapika kurí apekatú xinga se suí, kapiĩ resé. Amaã kurí ne resé se resá rakapira irumu asuí ti renheẽ kurí nẽ maã. Nheenga-itá ti uxari yandé yamaã puranga. Ma, muíri ara, rewapika kurí se ruakí piri...

43 - Le lendemain revint le petit prince.

43 - Amú ara ramé, muruxawamirĩ uyuíri. 
44 - "Il eût mieux valu revenir à la même heure, dit le renard. Si tu viens, par exemple, à quatre heures de l'après-midi, dès trois heures je commencerai d'être heureux. Plus l'heure avancera, plus je me sentirai heureux. À quatre heures, déjà, je m'agiterai et m'inquiéterai: je découvrirai le prix du bonheur! Mais si tu viens n'importe quand, je ne saurai jamais à quelle heure m'habiller le cœur... Il faut des rites.

44 - - Puranga piri maã reyuíri ramé maã yepé tẽ ara pisáwera ramé - unheẽ yawara kaapura. Reyuri ramé muíri ara karuka pitérupi, karuka yupirungawa ramé ana se rurí. Mairamé watari xinga resika renundé, ixé susangaíma ana: resika ramé kurí se rurí katú! Ma, reyuri ramé mairamé-ntu, ti mayé amukaturu se piá asuantí arama indé... Sesewara puranga maã yarikú yané rikusawa!

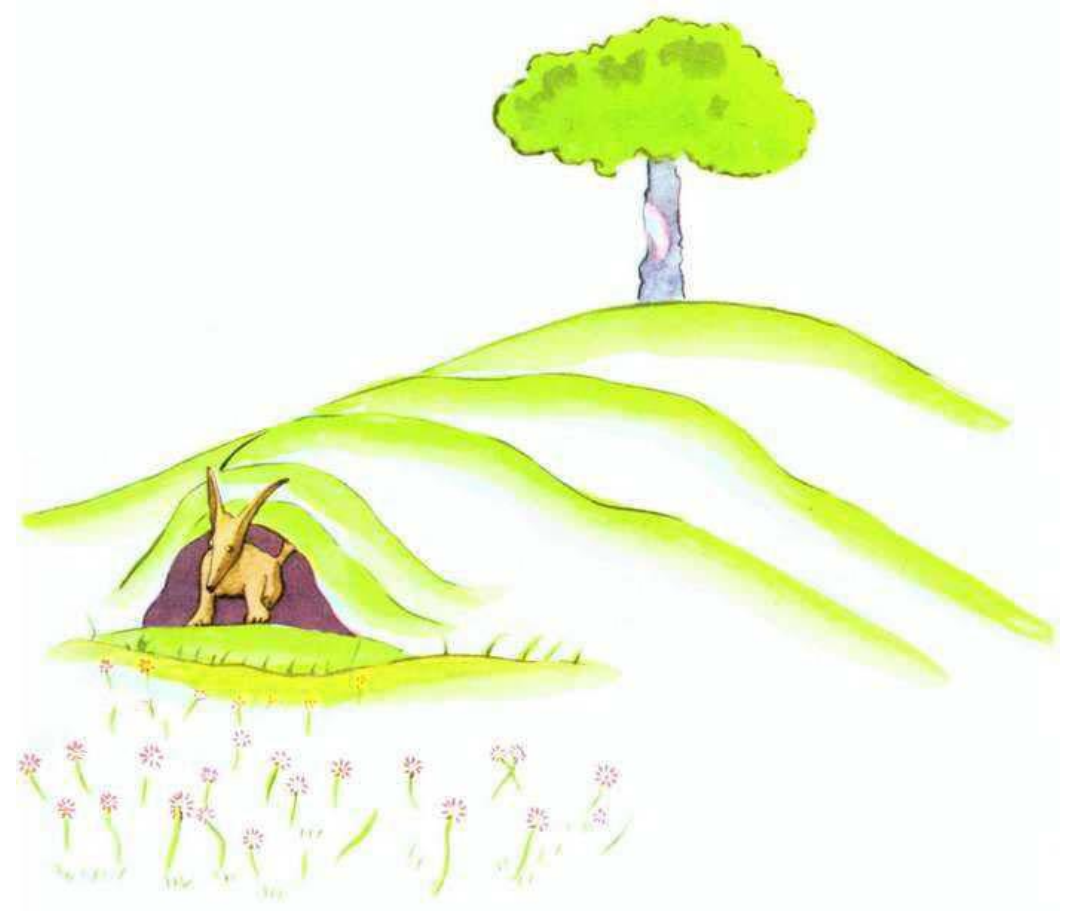

45 - - Qu'est-ce qu'un rite? dit le petit prince.

45 - - Maã taá renheẽ-putari “yané rikusawa” irumu? - unheẽ muruxawamirĩ.

46 - - C'est aussi quelque chose de trop oublié, dit le renard. C'est ce qui fait qu'un jour est différent des autres jours, une heure, des autres heures. Il y a un rite, par exemple, chez mes chasseurs. Ils dansent le jeudi avec les filles du village. Alors le jeudi est jour merveilleux! Je vais me promener jusqu'à la vigne. Si les chasseurs dansaient n'importe quand, les jours se ressembleraient tous, et je n'aurais point de vacances."

46 - - Kwá yuíri manungara mira-itá tá resarái waá - unheẽ yawara kaapura. Kwá umunhã yepé ara amurupí amú suí, yepé ara pisáwera amurupí amú-itá suí. Kamundusara-itá upurasí muíri supapáu kunhãmukú irumu tawa suiwara. Aramé supapáu yepé ara puranga retana! Kwá ara ramé, awatawara kukuratiwa rupí. Kamundusara-itá upurasí ramé maã mayewa ara ramé-ntu, ara-itá ti maã amurupí, asuí nẽ mairamé apituú-kwáu maã. 
47 - Ainsi, le petit prince apprivoisa le renard. Et quand l'heure du départ fut proche:

47 - Yawé, muruxawamirĩ uyusá yawara kaapura piá. Ma, mairamé urikuté usú i suí:

48 - "Ah! dit le renard... Je pleurerai.

48 - - Ah! - unheẽ yawara kaapura. - Ixé asú ayaxiú.

49 - - C'est ta faute, dit le petit prince, je ne te souhaitais point de mal, mais tu as voulu que je t'apprivoise...

49 - - Indé tẽ reputari kwayé - unheẽ muruxawamirĩ. - Ti maã axari-putari indé sasiara, ma indé reputari ixé ayusá maã ne piá...

50 - - Bien sûr, dit le renard.

50 - - Aputari tẽ - unheẽ yawara kaapura.

51 - - Mais tu vas pleurer! dit le petit prince.

51 - - Ma indé resú reyaxiú! - unheẽ muruxawamirĩ.

52 - - Bien sûr, dit le renard.

52 - - Asú tẽ - unheẽ yawara kaapura.

53 - - Alors tu n'y gagnes rien!

53 - - Ma ti kurí rerikú nẽ maã ne irumu!

54 - - J'y gagne, dit le renard, à cause de la couleur du blé."

54 - - Arikú kurí manungara supí - unheẽ yawara kaapura - awatí rawa resewara.

55 - Puis il ajouta:

55 - Asuí, aé umuapiri:

56 - "Va revoir les roses. Tu comprendras que la tienne est unique au monde. Tu reviendras me dire adieu, et je te ferai cadeau d'un secret."

56 - - Resú remaã amu í putira-itá piranga. Remaã kurí ne yara amurupí amú-itá suí. Reyuíri kurí renheẽ arã "té kurimirî” ixé arã, asuí ambéu kurí manungara indé arã.

57 - Le petit prince s'en fut revoir les roses:

57 - Aramé muruxawamirĩ usú umaã putira-itá piranga: 
58 - "Vous n'êtes pas du tout semblables à ma rose, vous n'êtes rien encore, leur dit-il. Personne ne vous a apprivoisées et vous n'avez apprivoisé personne. Vous êtes comme était mon renard. Ce n'était qu'un renard semblable à cent mille autres. Mais j'en ai fait mon ami, et il est maintenant unique au monde."

58 - - Penhẽ ti mayé se putira yawé, penhẽ ti rẽ nẽ maã. Nẽ awá rẽ uyusá penhẽ piá, penhẽ yuíri ti rẽ peyusá nẽ awá piá. Penhẽ mayé yawara kaapura yawé ixé akwáu renundé aé. Aé kwera yepé yawara kaapura mayé amú-itá yawé. Ma amuyeréu aé se rumuara arã, kuíri aé amurupí panhẽ yawara kaapura suí.

59 - Et les roses étaient bien gênées.

59 - Aramé putira-itá piranga upitá sasiara retana.

60 - "Vous êtes belles, mais vous êtes vides, leur dit-il encore. On ne peut pas mourir pour vous. Bien sûr, ma rose à moi, un passant ordinaire croirait qu'elle vous ressemble. Mais à elle seule elle est plus important que vous toutes, puisque c'est elle que j'ai arrosée. Puisque c'est elle que j'ai mise sous globe. Puisque c'est elle que j'ai abritée par le paravent. Puisque c'est elle dont j'ai tué les chenilles (sauf les deux ou trois pour les papillons). Puisque c'est elle que j'ai écoutée se plaindre, ou se vanter, ou même quelquefois se taire. Puisque c'est ma rose."

60 - - Penhẽ puranga, ma penhẽ ti rẽ amurupí ixé arã - unheẽ muruxawamirĩ. - Nẽ awá umanũ kurí penhẽ rupí. Amú mira umaité maã se putira mayé penhẽ yawé. Ma ixé arã aé purunga piri penhẽ suí, nhaãsé amururú aé. Nhaãsé amburi aé yepé riruwasú sakakanga upé. Nhaãsé apisirũ aé iwituwasú suí yepé iwitú-pitasukasara irumu. Nhaãsé ayuká tapurú-itá uikú waá sesé (axari-ntu mukũi u musapiri panapanã-itá resewara). Nhaãsé asendú aé ukururuka u upurungitá i purangasawa resé, asuí amuramé ukirirĩ. Nhaãsé aé se putira piranga.

$61-$ Et il revint vers le renard:

61 - Asuí uyuíri yawara kaapura piri:

62 - "Adieu, dit-il...

62 - - Té kurimirĩ... - unheẽ aé.

63 - - Adieu, dit le renard. Voici mon secret. Il est très simple: on ne voit bien qu'avec le cœur. L'essentiel est invisible pour les yeux.

63 - - Té kurimirĩ - unheẽ yawara kaapura. - Xukúi maã nẽ mairamé waá anheẽ nẽ awá supé: yamaã-ntu puranga yané piá irumu. Yané resá ti umaã-kwáu maã-itá rumitera.

64 - - L'essentiel est invisible pour les yeux, répéta le petit prince, afin de se souvenir.

64 - - Yané resá ti umaã-kwáu maã-itá rumitera - unheẽ muruxawamirĩ ti arã sesarái. 
65 - - C'est le temps que tu as perdu pour ta rose qui fait ta rose si importante.

65 - - Ara resasá waá ne putira irumu umuyeréu aé yepé putira amurupí amú-itá suí.

66 - - C'est le temps que j'ai perdu pour ma rose..., fit le petit prince, afin de se souvenir.

66 - - Ara asasá waá se putira irumu... - unheẽ muruxawamirĩ ti arã sesarái.

67 - - Les hommes ont oublié cette vérité, dit le renard. Mais tu ne dois pas l'oublier. Tu deviens responsable pour toujours de ce que tu as apprivoisé. Tu es responsable de ta rose...

67 - - Mira-itá tá resarái kwá supisawa - unheẽ yawara kaapura. - Té ne resarái i suí! Rerikuté repisirũ awá piá reyusá waá. Rerikuté repisirũ ne putira...

68 - - Je suis responsable de ma rose...”, répéta le petit prince, afin de se souvenir.

68 - - Arikuté apisirũ se putira... - unheẽ yuíri muruxawamirĩ ti arã sesarái.

1 - "Bonjour, dit le petit prince.

1 - - Yané ara - unheẽ muruxawamirĩ.

2 - - Bonjour, dit l'aiguilleur.

2 - - Yané ara - unheẽ mira-siyesara muyereusara.

3 - - Que fais-tu ici? dit le petit prince.

3 - - Maã taá remunhã iké? - upurandú muruxawamirĩ.

4 - - Je trie les voyageurs, par paquets de mille, dit l'aiguilleur. J'expédie les trains qui les emportent, tantôt vers la droite, tantôt vers la gauche."

4 - - Ambuí mira-itá suaxara-itá rupí, aikwé mira riía muíri suaxara suí - unheẽ muyereusara. - Amusemu mira-siyesara-itá urasú waá aintá, amuramé katusawa kití, amuramé yaparasawa kití...

5 - Et un rapide illuminé, grondant comme le tonnerre, fit trembler la cabine d'aiguillage.

5 - Aramé yepé mira-siyesara sendí, tiapuwara mayé tupã yawé, umurirí tendawa mamé muyereusara upurakí waá.

6 - "Ils sont bien pressés, dit le petit prince. Que cherchent-ils? 
6 - - Tá ranhẽ retana tá uikú - unheẽ muruxawamirĩ. - Maã taá aintá usikari uikú?

7 - - L'homme de la locomotive l'ignore lui-même", dit l'aiguilleur.

7 - - Nẽ mira-siyesara tiarisara ukwáu - unheẽ muyereusara.

8 - Et gronda, en sens inverse, un second rapide illuminé.

8 - Yepé tiapú uri uikú waá amú suaxara suí umukameẽ mukũisáwa mira-siyesara sendí.

9 - "Ils reviennent déjà? demanda le petit prince...

9 - - Mira-itá uyuíri ana uikú? - upurandú muruxawamirĩ.

10 - - Ce ne sont pas les mêmes, dit l'aiguilleur. C'est un échange.

10 - - Kwá amú mira-itá - unheẽ muyereusara. - Nhaã mira-itá usemu uikú asuí kwa-itá uwiké uikú.

11 - - Ils n'étaient pas contents, là où ils étaient?

11 - - Ti tá rurí será mamé tá uikú waá?

12 - - On n'est jamais content là où l'on est", dit l'aiguilleur.

12 - - Mira-itá nẽ mairamé tá rurí mamé tá uikú - unheẽ muyereusara.

13 - Et gronda le tonnerre d'un troisième rapide illuminé.

13 - Aramé, tá usendú tiapú uri uikú waá musapirisawa mira-siyesara sendí suí.

14 - "Ils poursuivent les premiers voyageurs? demanda le petit prince.

14 - - Kwá mira-itá uyana tá uikú amú mira-itá rakakwera usemu waá-itá kwá suí tá renundé? - upurandú muruxawamirĩ.

15 - - Ils ne poursuivent rien du tout, dit l'aiguilleur. Ils dorment là-dedans, ou bien ils bâillent. Les enfants seuls écrasent leur nez contre les vitres.

15 - - Aintá ti uyana tá uikú nẽ awá rakakwera - unheẽ muyereusara. - Tá ukiri mira-siyesara upé, tá ripusí tá uikú. Taína-itá-ntu upitá umaã ukara kití.

16 - - Les enfants seuls savent ce qu'ils cherchent, fit le petit prince. Ils perdent du temps pour une poupée de chiffons, et elle devient très importante, et si on la leur enlève, ils pleurent...

16 - - Taína-itá-ntu ukwáu maã tá usikari waá - unheẽ muruxawamirĩ. - Aintá usasá siía ara yepé taína-rangawa irumu asuí tá usaisú tá umusarái i irumu, tá uyaxiú mairamé amú awá upisika aé i suí... 
17 - - Ils ont de la chance", dit l'aiguilleur.

17 - - Aintá tá rurí... - unheẽ muyereusara.

1 - "Bonjour, dit le petit prince.

1 - - Yané ara - unheẽ muruxawamirĩ.

2 - - Bonjour", dit le marchand.

2 - - Yané ara - unheẽ venderisara.

3 - C'était un marchand de pilules perfectionnées qui apaisent la soif. On en avale une par semaine et l'on n'éprouve plus le besoin de boire.

3 - Aé yepé pusanga venderisara umupawa waá-itá isisawa. Ti arama yané isí yapitá, yarikuté yaú kwá pusanga yepé í muíri sumana.

4 - "Pourquoi vends-tu ça? dit le petit prince.

4 - - Marã taá revenderi kwá? - unheẽ muruxawamirĩ.

5 - - C'est une grosse économie de temps, dit le marchand. Les experts ont fait des calculs. On épargne cinquante-trois minutes par semaine.

5 - - Nhaãsé mira-itá urikú kurí ara piri sumana pukusawa - unheẽ venderisara. Ti ramé tá uú ií, tá umunhã-kwáu kurí amú maã-itá sumana pukusawa.

6 - - Et que fait-on de ces cinquante-trois minutes?

6 - - Maã taá aintá umunhã kurí sumana pukusawa?

7 - - On en fait ce que l'on veut...”

7 - - Maã-ntu tá uputari waá..."

8 - "Moi, se dit le petit prince, si j'avais cinquante-trois minutes à dépenser, je marcherais tout doucement vers une fontaine..."

8 - "Ixé", umanduari muruxawamirĩ, "arikú ramé maã ara piri sumana pukusawa, ixé awatá maã merupí té yepé ií-kwara kití..." 


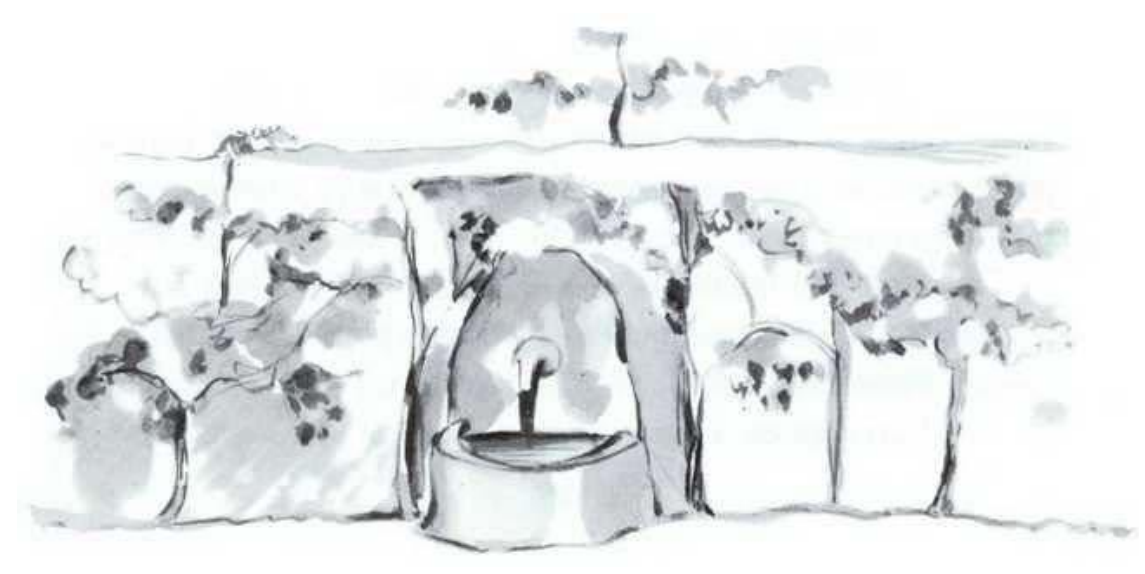

24

1 - Nous en étions au huitième jour de ma panne dans le désert, et j'avais écouté l'histoire du marchand en buvant la dernière goutte de ma provision d'eau:

1 - Aikwé ana pumusapiri ara se pepusantá upena uikú waá nhaã tetama miraíma upé. Mairamé muruxawamirĩ umbéu venderisara resewara, aú aikú se ií tikira anhuarama.

2 - “Ah! dis-je au petit prince, ils sont bien jolis, tes souvenirs, mais je n'ai pas encore réparé mon avion, je n'ai plus rien à boire, et je serais heureux, moi aussi, si je pouvais marcher tout doucement vers une fontaine!

2 - - Ah! - anheẽ muruxawamirĩ supé. - Ne manduarisawa-itá, tá puranga retana, ma ti rẽ amungaturú se pepusantá, ti arikú nẽ maã aú arã, se rurí maã yuíri awatá-kwáu ramé maã té yepé ií-kwara kití!

3 - - Mon ami le renard, me dit-il...

3 - - Se rumuara, yawara kaapura, unheẽ ixé arã...

4 - - Mon petit bonhomme, il ne s'agit plus du renard!

4 - - Apigawamirĩ, kwá amurupí yawara kaapura nheenga-itá suí!

5 - - Pourquoi?

5 - - Marã taá?

6 - - Parce qu'on va mourir de soif..."

6 - - Nhaãsé yasú yamanũ isisawa suí...

7 - Il ne comprit pas mon raisonnement, il me répondit:

7 - Aé ti umanduariwera mayé se yawé. Asuí, unheẽ ixé arama: 
8 - “C'est bien d'avoir eu un ami, même si l'on va mourrir. Moi, je suis bien content d'avoir eu un ami renard..."

8 - - Panhẽ mira umanũ kurí, ma, yané rikwesawa pukusawa, yarikuté yarikú yané rumuara. Se rurí retana arikú resewara yawara kaapura se rumuara yawé...

9 - "Il ne mesure pas le danger, me dis-je. Il n'a jamais ni faim ni soif. Un peu de soleil lui suffit..."

9 - "Aé ti umaã yawaitesawa turusawa", amanduari. "Nẽ mairamé i yumasí uikú nẽ i isí. Kurasí xinga uikú ana puranga i xupé..."

10 - Mais il me regarda et répondit à ma pensée:

10 - Ma aé umaã se resé asuí usuaxara se manduarisawa supé:

11 - "J'ai soif aussi... cherchons un puits..."

11 - - Se isí yuíri... yarikuté yasikari yepé ií-kwara...

12 - J'eus un geste de lassitude: il est absurde de chercher un puits, au hasard, dans l'immensité du désert. Cependant nous nous mîmes en marche.

12 - Ti aruyari aikú nhaã resé: usikari yepé ií-kwara nhaã tetama mira-íma turusú retana upé yepé akangaiwasawa. Ma, yawé tẽ, yayupirũ yawatá.

13 - Quand nous eûmes marché, des heures, en silence, la nuit tomba, et les étoiles commencèrent de s'éclairer.

13 - Yaikú ana kwera apekatú mairamé pituna usika asuí yasitatá-itá uyupirũ tá uwerá iwaka upé.

14 - Je les apercevais comme en rêve, ayant un peu de fièvre, à cause de ma soif. Les mots du petit prince dansaient dans ma mémoire:

14 - Ixé amaã yasitatá-itá mayé yepé kerpisawa upé, nhaãsé isisawa uxari ixé takua irumu. Nheenga-itá muruxawamirĩ unheẽ waá ti tá usemu se akanga suí.

15 - "Tu as donc soif, toi aussi?" lui demandai-je.

15 - - Ne isí yuíri? - apurandú i suí.

16 - Mais il ne répondit pas à ma question. Il me dit simplement:

16 - Ma aé ti usuaxara se purandusawa. Unheẽ-ntu kwayé:

17 - "L'eau peut aussi être bonne pour le cœur..."

17 - - Ií yuíri ukwáu katú yané piá supé... 
18 - Je ne compris pas sa réponse mais je me tus... Je savais bien qu'il ne fallait pas l'interroger.

18 - Ti akwáu maã aé unheẽ-putari waá, ma aikuntu... Amaã puranga piri ti apurandú-randú i suí.

19 - Il était fatigué. Il s'assit. Je m'assis auprès de lui. Et, après un silence, il dit encore:

19 - Aé i kweré ana uikú. Uwapika. Awapika suakí. Asuí, yepé kirirĩ riré, aé unheẽ rẽ:

20 - "Les étoiles sont belles, à cause d'une fleur que l'on ne voit pas..."

20 - - Yasitatá aintá puranga yepé putira resewara ti waá yamaã-kwáu...

21 - Je répondis “bien sûr” et je regardai, sans parler, les plis du sable sous la lune.

21 - Asuaxara "supí”, asuí akirirĩ. Amaã-maã iwikuí iwitera-itá sendí yasí rupí.

22 - "Le désert est beau", ajouta-t-il...

22 - - Tetama mira-íma puranga - aé unheẽ.

23 - Et c'était vrai. J'ai toujours aimé le désert. On s'assoit sur une dune de sable. On ne voit rien. On n'entend rien. Et cependant quelque chose rayonne en silence...

23 - Supí, tetama mira-íma puranga tẽ. Panhẽ mairamé asaisú tetama-itá miraíma. Yawapika yepé iwikuí iwitera resé. Ti yamaã nẽ maã. Ti yasendú nẽ maã. Ma, mairamé nẽ awá usarú uikú, manungara uwerá kirirĩ rupí...

24 - "Ce qui embellit le désert, dit le petit prince, c'est qu'il cache un puits quelque part..."

24 - - Yepé maã umupuranga tetama mira-íma - unheẽ muruxawamirĩ: aé uyumimi-kwáu yepé ií-kwara mayewa tendawa upé-ntu.

25 - Je fus surpris de comprendre soudain ce mystérieux rayonnement du sable. Lorsque j'étais petit garçon, j'habitais une maison ancienne, et la légende racontait qu'un trésor y était enfoui.

25 - Se akanhemu amaã resewara kwá amurupí iwikuí werasawa. Mairamé kwaíra rẽ ixé, amurari yepé uka kuxiimawara upé. Ape, tá umbeú marandua-itá, aikwé manungara mayé itá-tawá yawé uyutima uikú waá iwí upé.

26 - Bien sûr, jamais personne n'a su le découvrir, ni peut-être même ne l'a cherché. Mais il enchantait toute cette maison. Ma maison cachait un secret au fond de son cœur...

26 - Nẽ mairamé tá uwasemu-kwáu kwá itá-tawá, araneíma tẽ nẽ awá usikari ana aé. Ma kwá marandua umusurí panhẽ awá. Se ruka uyumimi manungara i piá kwara upé... 
27 - “Oui, dis-je au petit prince, qu'il s'agisse de la maison, des étoiles ou du désert, ce qui fait leur beauté est invisible!

27 - - Supí - anheẽ muruxawamirĩ supé -, uka, yasitatá-itá asuí tetama mira-íma, maã umupuranga aintá ti uyumaã-kwáu yané resá rupí!

28 - - Je suis content, dit-il, que tu sois d'accord avec mon renard."

28 - - Se rurí aikú - unheẽ muruxawamirĩ - remanduari resewara mayé yawara kaapura yawé.

29 - Comme le petit prince s'endormait, je le pris dans mes bras, et me remis en route. J'étais ému. Il me semblait porter un trésor fragile.

29 - Mayé muruxawamirĩ ukiri ana uikú, amburi aé se iuwá resé asuí awatá se renundé kití. Aramé, se piá surí retana nhaãsé arasú aikú se irumu nhaã apigawamirĩ itá-tawá nungara.

30 - Il me semblait même qu'il n'y eût rien de plus fragile sur la Terre. Je regardais, à la lumière de la lune, ce front pâle, ces yeux clos, ces mèches de cheveux qui tremblaient au vent, et je me disais:

30 - Uyukwáu ixé arama aé maã pitua piri aikwé waá Iwí upé. Amaã aikú, yasí werasawa irumu, nhaã suá suaíwa, sesá-itá usikindáu, i awa urirí waá iwitú irumu. Aramé, amanduari:

31 - “Ce que je vois là n'est qu'une écorce. Le plus important est invisible..."

31 - “Maã amaã aikú kuíri i pira-ntu. Yané resá ti umaã-kwáu maã-itá rumitera..."

32 - Comme ses lèvres entrouvertes ébauchaient un demi-sourire je me dis encore: "Ce qui m'émeut si fort de ce petit prince endormi, c'est sa fidélité pour une fleur, c'est l'image d'une rose qui rayonne en lui comme la flamme d'une lampe, même quand il dort..."

32 - Mayé sembé-itá umukameẽ yepé pukasawa nungara, amanduari rẽ: "Se piá upitá surí akwáu resewara kwá muruxawamirĩ nhaãsé aé panhẽ mairamé usaisú kurí i putira. Amaã putira rangawa uwerá waá sesé mayé lamparina werasawa yawé, té mairamé aé ukiri uikú..."

33 - Et je le devinai plus fragile encore. Il faut bien protéger les lampes: un coup de vent peut les éteindre...

33 - Aramé amaité aé pitua piri rẽ. Yarikuté yapisirũ katú lamparina-itá: araneíma iwitú xinga umuwéu ana aintá...

34 - Et, marchant ainsi, je découvris le puits au lever du jour.

34 - Awatá rẽ se renundé kití asuí awasemu yepé ií-kwara mairamé kurasí usemu. 
1 - 'Les hommes, dit le petit prince, ils s'enfournent dans les rapides, mais ils ne savent plus ce qu'ils cherchent. Alors ils s'agitent et tournent en rond..."

1 - - Mira-itá - unheẽ muruxawamirĩ - tá uyuruari mira-siyesara-itá upé, ma ti tá ukwáu maã tá uwasemu. Aintá uwatá, ma ti tá ukwáu makití tá usú...

$2-$ Et il ajouta:

2 - Asuí aé umuapiri:

3 - "Ce n'est pas la peine..."

3 - - Kwá yepé tenhuntusawa...

4 - Le puits que nous avions atteint ne ressemblait pas aux puits sahariens. Les puits sahariens sont de simples trous creusés dans le sable. Celui-là ressemblait à un puits de village. Mais il n’y avait là aucun village, et je croyais rêver.

4 - Ií-kwara mamé yasika amurupí ií-kwara suí yamaã waá-itá Saara upé. Iíkwara Saarawara yepé-ntu kwara iwikuí upé. Ma nhaã mayé ií-kwara yawé yamaã waá tawa upé. Ma, mayé ti aikwé nẽ yepé tawa ape, amaité se kerpi aikú.

5 - "C'est étrange, dis-je au petit prince, tout est prêt: la poulie, le seau et la corde..."

5 - - Kwá amurupí - anheẽ muruxawamirĩ supé. - Panhẽ maã tá uikú ana iké: iíkwara wawakawara, ií rirú, tupasama...

6 - Il rit, toucha la corde, fit jouer la poulie.

6 - Aé upuká, upisika tupasama, asuí umuyeréu ií-kwara wawakawara.

7 - Et la poulie gémit comme gémit une vieille girouette quand le vent a longtemps dormi.

7 - Nhaã ií-kwara wawakawara ukururuka mayé yepé iwitú wawakawara aíwa yawé, mairamé uikupukú ana iwitú-íma.

8 - "Tu entends, dit le petit prince, nous réveillons ce puits et il chante..."

8 - - Resendú será? - unheẽ muruxawamirĩ. - Yapaka kwá ií-kwara asuí aé unheengari uikú...

9 - Je ne voulais pas qu'il fît un effort:

9 - Ti aputari muruxawamirĩ i kweré upitá:

10 - "Laisse-moi faire, lui dis-je, c'est trop lourd pour toi."

10 - - Rexari ixé asikí - anheẽ i xupé. - I pusé retana indé arã. 
11 - Lentement je hissai le seau jusqu'à la margelle. Je l'y installai bien d'aplomb. Dans mes oreilles durait le chant de la poulie et, dans l'eau qui tremblait encore, je voyais trembler le soleil.

11 - Merupí asikí ií rirú té ií-kwara rembiwa, asuí axari aé mimi. Ií-kwara wawakawara nheengarisawa uikú rẽ se apisá upé, asuí ií upé urirí uikú rẽ waá ixé amaã-kwáu kurasí werasawa.

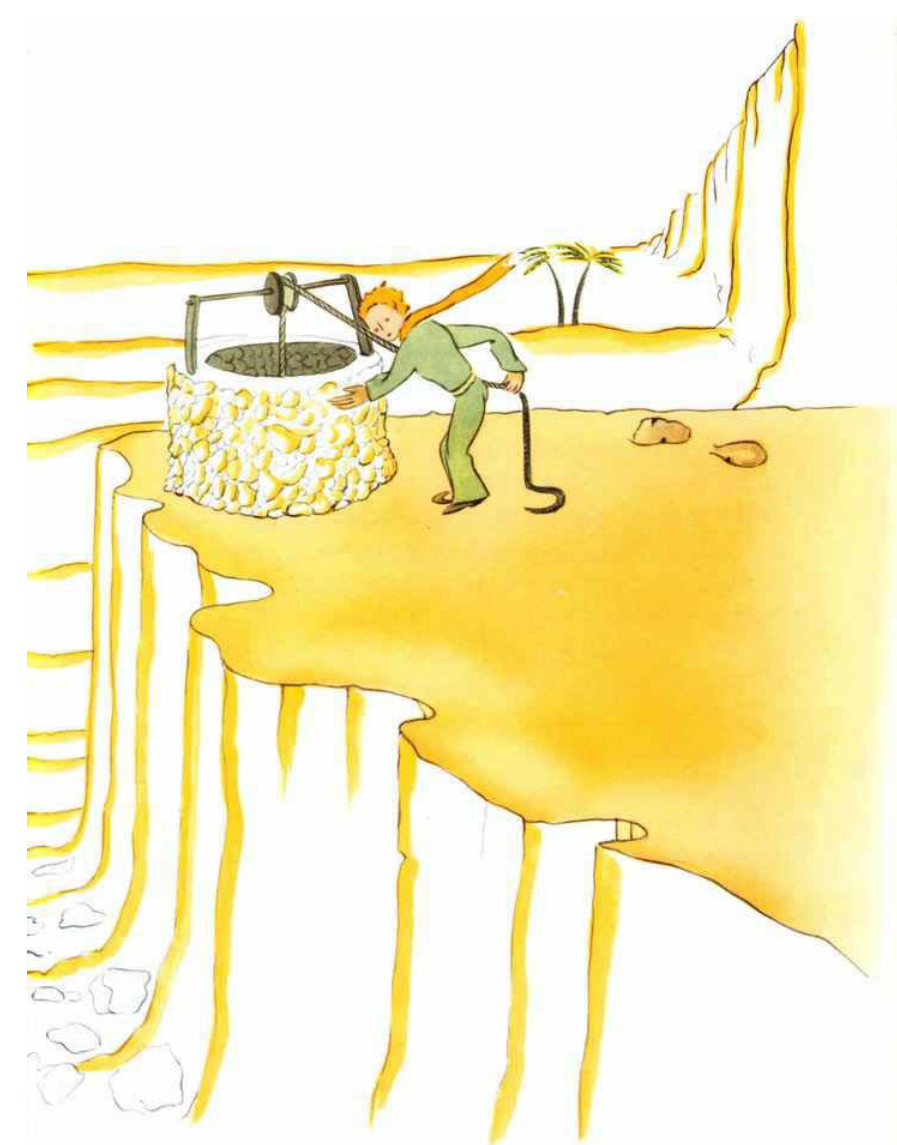

12 - "J'ai soif de cette eau-là, dit le petit prince, donne-moi à boire..."

12 - - Aú-putari kwá ií - unheẽ muruxawamirĩ. - Remeẽ aú arã kwá ií...

13 - Et je compris ce qu'il avait cherché!

13 - Aramé amaã maã muruxawamirĩ usikari uikú waá!

14 - Je soulevai le seau jusqu'à ses lèvres. Il but, les yeux fermés. C'était doux comme une fête. Cette eau était bien autre chose qu'un aliment. Elle était née de la marche sous les étoiles, du chant de la poulie, de l'effort de mes bras. Elle était bonne pour le cœur, comme un cadeau.

14 - Asupiri ií rirú té i yurú. Aé uú ií, ti upirari sesá-itá. Nhaã seẽ mayé yepé murasí yawé. Nhaã ií, aé piri timbiú suí. Aé usemu watasawa suí yasitatá-itá wírupi, ií-kwara wawakawara nheengarisawa suí, se iuwá kirimbasawa suí. Aé katú piá supé, mayé yepé meẽsawa yawé. 
15 - Lorsque j'étais petit garçon, la lumière de l'arbre de Nöel, la musique de la messe de minuit, la douceur des sourires faisaient, ainsi, tout le rayonnement du cadeau de Nöel que je recevais.

15 - Mairamé kwaíra rẽ ixé, Natal mirá werasawa, tupauku nheengarisawa pisayé ramé asuí pukasawa-itá seẽsawa, tá uxari puranga piri meẽsawa tá umeẽ waá ixé arama.

16 - "Les hommes de chez toi, dit le petit prince, cultivent cinq mille roses dans un même jardin... et ils n'y trouvent pas ce qu'ils cherchent...

16 - - Mira-itá ikewara - unheẽ muruxawamirĩ - tá urikú siía putira piranga yepé putiratiwa upé... ma ti tá uwasemu maã tá usikari waá.

17 - - Ils ne le trouvent pas, répondis-je...

17 - - Aintá ti tẽ uwasemu - anheẽ...

18 - - Et cependant ce qu'ils cherchent pourrait être trouvé dans une seule rose ou un peu d'eau...

18 - - Ma maã tá usikari waá, tá uwasemu-kwáu maã yepé-ntu putira resé u ií xinga resé...

19 - - Bien sûr", répondis-je.

19 - - Supí - anheẽ.

20 - Et le petit prince ajouta:

20 - Asuí muruxawamirĩ unheẽ rẽ:

21 - "Mais les yeux sont aveugles. Il faut chercher avec le cœur."

21 - - Yané resá ti umaã puranga. Yamaã-ntu puranga yané piá irumu...

22 - J'avais bu. Je respirais bien. Le sable, au lever du jour, est couleur de miel. J'étais heureux aussi de cette couleur de miel. Pourquoi fallait-il que j'eusse de la peine...

22 - Ixé aú ana ií asuí asikí se anga puranga. Iwikuí, kurasí usemu ramé, mayé ira yawé. Ira pinimasawa uxariwara ixé se rurí. Marã taá, aramé, sasiara aikú?...

23 - "Il faut que tu tiennes ta promesse, me dit doucement le petit prince, qui, de nouveau, s'était assis auprès de moi.

23 - - I katú rẽ remunhã maã renheẽ waá ixé arã - unheẽ muruxawamirĩ, uwapika ana uikú waá, amu í, se ruakí.

24 - - Quelle promesse?

24 - - Maã taá ixé anheẽ? 
25 - - Tu sais... une muselière pour mon mouton... je suis responsable de cette fleur!"

25 - - Indé rekwáu... yepé yurú-pukwarisara se suumé mimbira supé... arikuté apisirũ nhaã putira!

26 - Je sortis de ma poche mes ébauches de dessin. Le petit prince les aperçut et dit en riant:

26 - Aramé apisika se rangawa-itá. Muruxawamirĩ umaã aintá resé asuí unhẽ̃ upuká:

27 - “Tes baobabs, ils ressemblent un peu à des choux...

27 - - Ne baobá-itá, tá mayé karurú yawé...

$28--\mathrm{Oh} ! ”$

$28--$ Oh!

29 - Moi qui étais si fier des baobabs!

29 - Amaité se baoba-itá uikú puranga!

30 - "Ton renard... ses oreilles... elles ressemblent un peu à des cornes... et elles sont trop longues!"

30 - - Ne yawara kaapura... i nambí-itá... aka-itá nungara... tá pukú retana!

$31-$ Et il rit encore.

31 - Aé upuká amu í.

32 - "Tu es injuste, petit bonhomme, je ne savais rien dessiner que les boas fermés et les boas ouverts.

32 - - Kwá iwasú ixé arã, apigawamirĩ. Ixé akwatiariwera-ntu buyawasú-itá...

33 - - Oh! ça ira, dit-il, les enfants savent."

33 - - Puranga pá! - unheẽ muruxawamirĩ. - Taína-itá umaã puranga.

34 - Je crayonnai donc une muselière. Et j' eus le cœur serré en la lui donnant:

34 - Aramé, kutara nungara akwatiari yepé yurú-pukwarisara. Ma, mairamé ameẽ aé muruxawamirĩ supé, asaã yepé muasisawa se piá upé:

35 - "Tu as des projets que j'ignore..."

35 - - Indé remanduari reikú manungara resé ti rẽ waá rembeú ixé arã...

36 - Mais il ne me répondit pas. Il me dit: 
36 - Ma aé ti usuaxara ixé arama. Asuí, unheẽ:

37 - "Tu sais, ma chute sur la Terre... c'en sera demain l'anniversaire...”

37 - "Remanduari será mairamé asika Iwí kití? Wirandé kurí akayú ara...

38 - Puis, après un silence il dit encore:

38 - Asuí, yepé kirirĩ riré, aé unheẽ rẽ:

39 - "J'étais tombé tout près d'ici..."

39 - - Awari kwá ruakí...

$40-$ Et il rougit.

40 - Suá upitá piranga.

41 - Et de nouveau, sans comprendre pourquoi, j'éprouvai un chagrin bizarre. Cependant une question me vint:

41 - Amú í, ti akwáu maã resewara sasiara aikú. Ma, apurandú-putari i suí:

42 - “Alors ce n'est pas par hasard que, le matin où je t'ai connu, il y a huit jours, tu te promenais comme ça, tout seul, à mille milles de toutes les régions habitées! Tu retournais vers le point de ta chute?"

42 - - Aramé, mairamé asuantí indé aikwé ana pumusapiri ara, apekatú retana mayewa tetama suí-ntu mamé mira-itá umurari, indé reyuíri reikú tendawa kití mamé resika?

43 - Le petit prince rougit encore.

43 - Muruxawamirĩ ruá upitá piranga amú í.

44 - Et j'ajoutai, en hésitant:

44 - Asuí amuapiri:

45 - "À̀ cause, peut-être, de l'anniversaire?..."

45 - - Araneíma akayú ara resewara?...

46 - Le petit prince rougit de nouveau. Il ne répondait jamais aux questions, mais, quand on rougit, ça signifie "oui", n'est-ce pas?

46 - Muruxawamirĩ ruá upitá piranga piri rẽ. Nẽ mairamé usuaxara se purandusawa-itá. Ma, mairamé amú awá ruá upitá piranga, kwá mira unheẽputari "eẽ", ti será?

47 - “Ah! lui dis-je, j’ai peur...” 
47 - - Ah! - anheẽ i xupé. Asikié...

48 - Mais il me répondit:

48 - Ma aé usuaxara ixé arama:

49 - "Tu dois maintenant travailler. Tu dois repartir vers ta machine. Je t'attends ici. Reviens demain soir..."

49 - - Kuíri i katú piri indé repuraki. Reyuíri makití ne pepusantá uikú. Asarú indé iké. Reyuíri wirandé pituna ramé...

50 - Mais je n'étais pas rassuré. Je me souvenais du renard. On risque de pleurer un peu si l'on s'est laissé apprivoiser...

50 - Ma ti aruyari sesé. Amanduari yawara kaapura resewara. Araneíma yandé yayaxiú xinga mairamé amú awá uyusá yané piá...

26

1 - Il y avait, à côté du puits, une ruine de vieux mur de pierre. Lorsque je revins de mon travail, le lendemain soir, j'aperçus de loin mon petit prince assis là-haut, les jambes pendantes. Et je l'entendis qui parlait:

1 - Aikwé, nhã̃ ií-kwara ruakí, yepé uka rupitá kwera itá suiwara. Mairamé ayuíri se murakí suí, amú ara ramé, amaã, apekatú retana, se muruxawamirĩ uwapika uka rupitá upé, uyatimú setimã-itá. Aramé, asendú aé unheẽ:

2 - "Tu ne t'en souviens donc pas? disait-il. Ce n'est pas tout à fait ici!"

2 - - Indé ne resarái será? - unheẽ aé. - Iké ti tendawa!

3 - Une autre voix lui répondit sans doute, puisqu'il répliqua:

3 - Amú nheenga usuaxara i xupé, nhaãsé muruxawamirĩ unheẽ rẽ:

4 - “Si! Si! c'est bien le jour, mais ce n'est pas ici l'endroit..."

4 - - Eré, uií ara, ma tendawa ti iké...

5 - Je poursuivis ma marche vers le mur. Je ne voyais ni n'entendais toujours personne. Pourtant le petit prince répliqua de nouveau:

5 - Aramé, awatá nhaã uka rupitá kití. Ti amaã asuí ti asendú nẽ awá. Ma, amú í, muruxawamirĩ unheẽ:

6 - “... Bien sûr. Tu verras où commence ma trace dans le sable. Tu n'as qu'à m'y attendre. J'y serai cette nuit." 
6 - - ... Eré. Remaã kurí iwikuí upé marupí awatá ana. Resarú-ntu ixé. Aikú kurí ape kwá pituna ramé.

7 - J'étais à vingt mètres du mur et je ne voyais toujours rien.

7 - Aikú ana nhaã uka rupitá ruakí ma ti rẽ amaã-kwáu nẽ maã.

8 - Le petit prince dit encore, après un silence:

8 - Muruxawamirĩ unheẽ rẽ, yepé kirirĩ riré:

9 - "Tu as du bon venin? Tu es sûr de ne pas me faire souffrir longtemps?"

9 - - Puranga tẽ será ne sasisawa? Kwá sasisawa ti kurí umupurará ixé ara pukú rupí?

10 - Je fis halte, le cœur serré, mais je ne comprenais toujours pas.

10 - Apitá ape, se piá i akanhemu, ma ti rẽ asendú aikú nẽ maã.

11 - "Maintenant, va-t'en, dit-il... Je veux redescendre!"

11 - - Kuíri tẽ, resemu kwá suí - unheẽ muruxawamirĩ... - Ixé awiyé-putari!

12 - Alors j'abaissai moi-même les yeux vers le pied du mur, et je fis un bond! Il était là, dressé vers le petit prince, un de ces serpentes jaunes qui vous exécutent en trente secondes.

12 - Aramé, amaã iwí kití, uka rupitá pí ruakí, asuí se akanhemu! Nhaã tendawa upé, upuámu uikú muruxawamirĩ ruakí yepé buya tawá uyuká-kwáu maã waá aé kutara retana!

13 - Tout en fouillant ma poche pour en tirer mon revolver, je pris le pas de course, mais, au bruit que je fis, le serpent se laissa doucement couler dans le sable, comme un jet d'eau qui meurt, et, sans trop se presser, se faufila entre les pierres avec un léger bruit de métal.

13 - Yeperesé asikari se mukawamirĩ asuí awatá kutara piri, ma, mairamé usendú tiapú amunhã waá, nhaã buya ukanhemu iwikuí upé mayé ií rapé yawé utipáu kutara waá, asuí merupí uyumundéu siía itá pitérupi. 


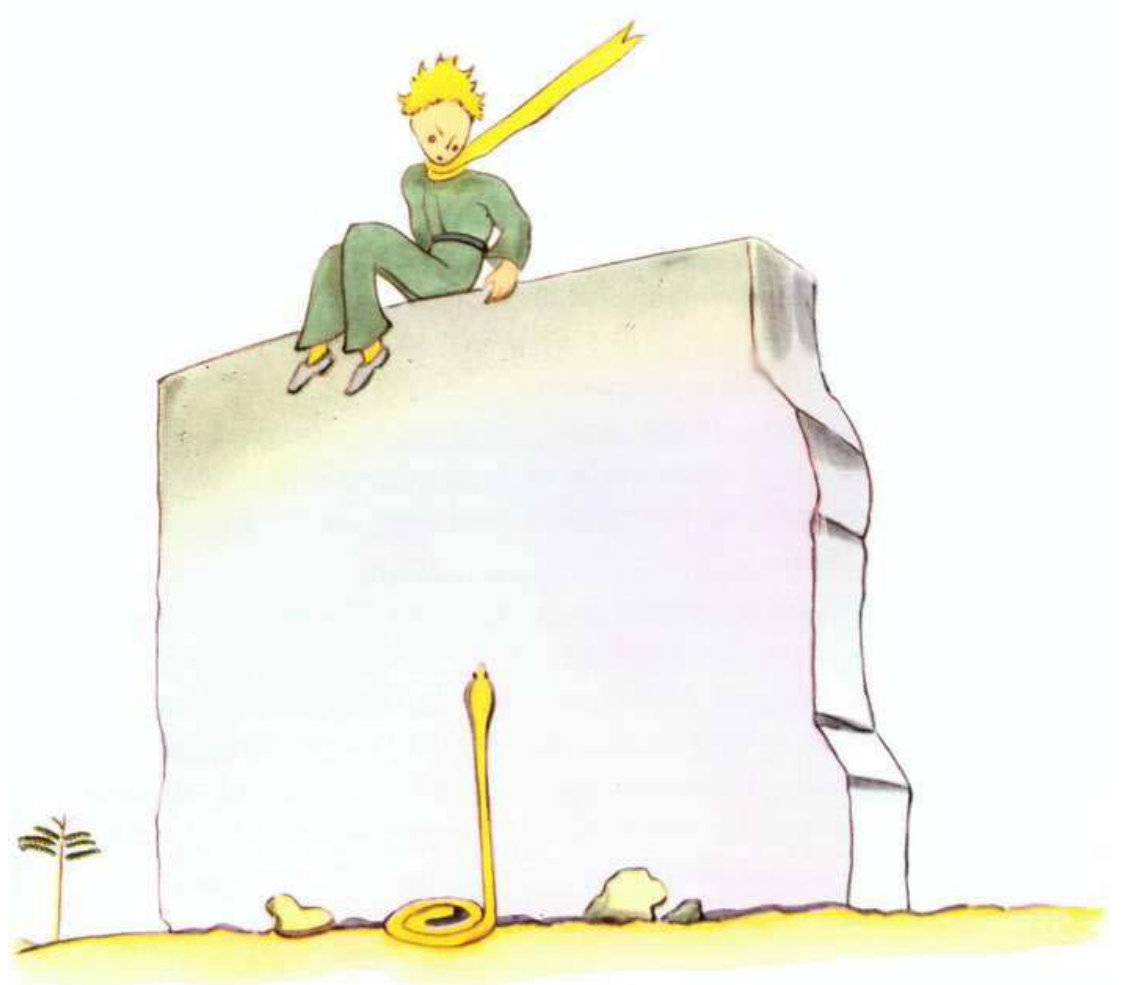

14 - Je parvins au mur juste à temps pour y recevoir dans les bras mon petit bonhomme de prince, pâle comme la neige.

14 - Asika uka rupitá kití asuí asupiri-kwáu muruxawamirĩ se iuwá resé, aé suaíwa uikú mayé iwikuí yawé.

15 - "Quelle est cette histoire-là! Tu parles maintenant avec les serpents!"

15 - - Maã taá indé remunhã reikú iké? Repurungitá kuíri buya-itá irumu?

16 - J'avais défait son éternel cache-nez d'or. Je lui avais mouillé les tempes et l'avais fait boire. Et maintenant je n'osais plus rien lui demander.

16 - Ayurari panu kitanga aé ururiwera waá i ayura resé. Amururú i siwá asuí ameẽ ií mirĩ i xupé. Aramé ti apurandú nẽ maã i suí.

17 - Il me regarda gravement et m'entoura le cou de ses bras. Je sentais battre son cœur comme celui d'un oiseau qui meurt, quand on l'a tiré à la carabine. Il me dit:

17 - Umaã pusé se resá resé asuí uyumana se ayura. Asaã i piá utuká mayé wirá piá yawé umanũ uikú waá yepé mukawa puka resewara. Aé unheẽ ixé arama:

18 - "Je suis content que tu aies trouvé ce qui manquait à ta machine. Tu vas pouvoir rentrer chez toi...

18 - - Se rurí aikú nhaãsé remungaturú-kwáu ana ne pepusantá. Reyuíri-kwáu kurí ne ruka kití... 
19 - - Comment sais-tu!”

19 - - Mayé taá indé rekwáu ana?

20 - Je venais justement lui annoncer que, contre toute espérance, j’avais réussi mon travail!

20 - Ayuri anheẽ arama i xupé, iwasusawa turusú irumu, ixé amupawa ana se murakí!

21 - Il ne répondit rien à ma question, mais il ajouta:

21 - Aé ti usuaxara se purandusawa, ma umuapiri:

22 - "Moi aussi, aujourd'hui, je rentre chez moi..."

22 - - Ixé yuíri ayuíri kurí uií se ruka kití...

23 - Puis, mélancolique:

23 - Asuí, sasiara xinga, unheẽ:

24 - "C'est bien plus loin... c'est bien plus difficile..."

24 - - Se rapé pukú piri retana... iwasú piri retana...

25 - Je sentais bien qu'il se passait quelque chose d'extraordinaire.

25 - Asaã tẽ manungara amurupí retana usika uikú.

26 - Je le serrais dans les bras comme un petit enfant, et cependant il me semblait qu'il coulait verticalement dans un abîme sans que je puisse rien pour le retenir...

26 - Ayumana kirimbawa aé mayé aé ramé maã yepé tainamirĩ, ma uwari pu uikú yepé kwara tipí upé asuí ti amunhã-kwáu nẽ maã apitimũ arama aé...

27 - Il avait le regard sérieux, perdu très loin:

27 - Sesá-itá ana pusé, tá ukanhemu tá uikú, apekatú retana:

28 - “J'ai ton mouton. Et j'ai la caisse pour le mouton. Et j'ai la muselière..."

28 - - Arikú ne suumé mimbira, i patuá asuí i yurú-pukwarisara...

29 - Et il sourit avec mélancolie.

29 - Aé upuká, ma sasiara xinga uikú.

30 - J'attendis longtemps. Je sentais qu'il se réchauffait peu à peu:

30 - Asarú retana. Asaã i pira uyumuakú merupí amú í: 
31 - "Petit bonhomme, tu as eu peur..."

31 - - Apigawamirĩ, resikié...

32 - Il avait eu peur, bien sûr! Mais il rit doucement:

32 - Supí, aé usikié! Ma upuká seẽ:

33 - "J'aurai bien plus peur ce soir..."

33 - - Asikié piri rẽ kwá pituna ramé...

34 - De nouveau je me sentis glacé par le sentiment de l'irréparable. Et je compris que je ne supportais pas l'idée de ne plus jamais entendre ce rire. C'était pour moi comme une fontaine dans le désert.

34 - Amú í asikié nhaãsé asaã ti maã apitimũ-kwáu aé. Asikié ti asendú amú í nhaã pukasawa. Aé ixé arama mayé yepé ií-kwara yawé tetama mira-íma upé.

35 - "Petit bonhomme, je veux encore t'entendre rire..."

35 - - Apigawamirĩ, asendú-putari rẽ ne pukasawa...

36 - Mais il me dit:

36 - Ma aé unheẽ ixé arama:

37 - "Cette nuit, ça fera un an. Mon étoile se trouvera juste au-dessus de l'endroit où je suis tombé l'année dernière...

37 - - Kwá pituna ramé, aikwé ana yepé akayú asika waá iké. Se yasitatá uikú kurí tendawa árupi mamé asika akayú kwera ramé...

38 - - Petit bonhomme, n'est-ce pas que c'est un mauvais rêve cette histoire de serpent et de rendez-vous et d'étoile..."

38 - - Apigawamirĩ, yepé-ntu kerpisawa puxiwera kwá mbeusawa buya, suantisawa asuí yasitatá resewara...

39 - Mais il ne répondit pas à ma question. Il me dit:

39 - Ma ti usuaxara se purandusawa. Asuí, unheẽ rẽ:

40 - "Ce qui est important, ça ne se voit pas...

40 - - Maã-itá rumitera, yané resá ti umaã-kwáu...

41 - - Bien sûr...

41 - - Supí... 
42 - - C'est comme pour la fleur. Si tu aimes une fleur qui se trouve dans une étoile, c'est doux, la nuit, de regarder le ciel. Toutes les étoiles sont fleuries.

42 - - Putira yawé. Resaisú ramé yepé putira uikú waá yepé yasitatá upé, puranga retana remaã iwaka kití pituna ramé. Panhẽ yasitatá tá upitá putirawara.

43 - - Bien sûr...

43 - - Tá upitá tẽ...

44 - - C'est comme pour l'eau. Celle que tu m'as donnée à boire était comme une musique, à cause de la poulie et de la corde... tu te rappelles... elle était bonne.

44 - - Ií yawé. Ií remeẽ waá ixé arã nheengarisawa nungara, ií-kwara wawakawara asuí tupasama resewara... Remanduari será?... kwá ií i katú

45 - - Bien sûr...

45 - - Eẽ, ixé amanduari...

46 - - Tu regarderas, la nuit, les étoiles. C'est trop petit chez moi pour que je te montre où se trouve la mienne. C'est mieux comme ça. Mon étoile, ça sera pour toi une des étoiles. Alors, toutes les étoiles, tu aimeras les regarder... Eles seront toutes tes amies. Et puis je vais te faire un cadeau..."

46 - - Pituna ramé, remaã kurí yasitatá-itá resé. Se retama kwairamirĩ, ti amukameẽ-kwáu indé arã mamé upitá se yasitatá. Ma... yawé puranga piri. Se yasitatá kurí indé arã yepé amú-itá pitérupi. Aramé, resaisú kurí remaã panhẽ aintá... Aintá kurí ne rumuara-itá. Asuí, axari kurí yepé kwekatú indé arã...

47 - Il rit encore.

47 - Aé upuká amú í.

48 - “Ah! petit bonhomme, petit bonhomme, j'aime entendre ce rire!

48 - - Ah! Apigawamirĩ, se rumuara, ne pukasawa umusurí ixé!

49 - - Justement ce sera mon cadeau... ce sera comme pour l'eau...

49 - - Se pukasawa, aé kurí se kwekatú indé arã... aé kurí mayé ií yawé...

50 - - Que veux-tu dire?

50 - - Maã taá renheẽ-putari?

51 - - Les gens ont des étoiles qui ne sont pas les mêmes. Pour les uns, qui voyagent, les étoiles sont des guides. Pour d'autres elles ne sont rien que de petites lumières. Pour d'autres, qui sont savants, elles sont des problèmes. Pour mon businessman elles étaient de l'or. Mais toutes ces étoiles-lá se taisent. Toi, tu auras des étoiles comme personne n'en a... 
51 - - Muíri mira umaã manungara amurupí mairamé umaã yasitatá-itá. Tá umukameẽ pé-itá watawera-itá supé. Amú mira-itá umaité aintá maãmirĩ uwerá waá-itá. Kwawara-itá umaité aintá iwasusawa-itá. Nhaã apigawa umunhãwera-ntu waá paparisawa-itá umaité aintá itá-tawá nungara. Ma panhẽ yasitatá ukirirĩ. Indé, amurupí kwá mira-itá suí, rerikú kurí yasitatá-itá mayé nẽ awá yawé nẽ mairamé urikú ana aintá...

52 - - Que veux-tu dire?

52 - - Maã taá renheẽ-putari?

53 - - Quand tu regarderas le ciel, la nuit, puisque j'habiterai dans l'une d'elles, puisque je rirai dans l'une d'elles, alors ce sera pour toi comme si riaient toutes les étoiles. Tu auras, toi, des étoiles qui savent rire!"

53 - - Mairamé remaã iwaka kití pituna ramé, aikú kurí yepé yasitatá upé, ape apuká kurí aikú; kwá kurí, indé arã, mayé panhẽ yasitatá upuká ramé maã. Yawé, indé-ntu rerikú kurí yasitatá-itá upuká-kwáu waá-itá.

$54-$ Et il rit encore.

54 - Asuí upuká amú í.

55 - "Et quand tu seras consolé (on se console toujours) tu seras content de m'avoir connu. Tu seras toujours mon ami. Tu auras envie de rire avec moi. Et tu ouvriras parfois ta fenêtre, comme ça, pour le plaisir... Et tes amis seront bien étonnés de te voir rire en regardant le ciel. Alors tu leur diras: "Oui, les étoiles, ça me fait toujours rire!" Et ils te croiront fou. Je t'aurai joué un bien vilain tour..."

55 - - Mairamé kwá ara usasá (yané rikwesawa ramé panhẽ maã usasá), reyumusurí kurí rekwáu ana resewara ixé. Panhẽ mairamé indé kurí se rumuara. Repuká-putari kurí se irumu. Amuramé repirari kurí ne ruka ukenaĩ reyumusurí arã-ntu... Ne rumuara-itá ti kurí tá ukwáu nhaãsé repuká-puká mairamé remaã iwaka kití. Aramé renheẽ kurí tá supé: "Yasitatá-itá panhẽ mairamé tá umupuká ixé!" Mira-itá umanduari kurí indé akangaíwa repitá. Kwá kurí yané musaraisawa...

56 - Et il rit encore.

56 - Muruxawamirĩ upuká amú í.

57 - “Ce sera comme si je t'avais donné, au lieu d'étoiles, des tas de petits grelots qui savent rire..."

57 - - Kwá kurí mayé ameẽ ramé maã indé arã marakamirĩ riía upuká-kwáu waáitá...

58 - Et il rit encore. Puis il redevint sérieux:

58 - Amú í aé upuká. Asuí, ukirirĩ: 
59 - "Cette nuit... tu sais... ne viens pas.

59 - - Kwá pituna ramé... ayururéu ne suí... ti aputari reyuri.

$60--$ Je ne te quitterai pas.

60 - - Ti kurí axari indé.

61 - - J'aurai l'air d'avoir mal... j'aurai un peu l'air de mourir. C'est comme ça. Ne viens pas voir ça, ce n'est pas la peine...

61 - - Remanduari kurí ixé apurará aikú... remanduari kurí amanũ aikú. Yawé tẽ. Té reyuri remaã ixé! Ti mayé...

62 - - Je ne te quitterai pas.”

62 - - Ti kurí axari indé.

63 - Mais il était soucieux.

63 - Ma aé i akanhemu uikú.

64 - “Je te dis ça... c'est à cause aussi du serpent. Il ne faut pas qu'il te morde... Les serpents, c'est méchant. Ça peut mordre pour le plaisir...

64 - - Ayururéu ne suí... yuíri buya resewara. Ti aputari aé usuú indé... Buya-itá puxí. Tá usaisú tá usuú...

65 - - Je ne te quitterai pas."

65 - - Ti kurí axari indé.

66 - Mais quelque chose le rassura:

66 - Ma manungara umupituú xinga aé:

67 - “C'est vrai qu'ils n'ont plus de venin pour la seconde morsure...”

67 - - Supisawa ti waá tá urikú sasisawa mukũisáwa suusawa supé...

68 - Cette nuit-là je ne le vis pas se mettre en route. Il s'était évadé sans bruit. Quand je réussis à le rejoindre il marchait décidé, d'un pas rapide. Il me dit seulement:

68 - Nhaã pituna ramé, ti amaã aé usú se suí. Aé usemu tiapú-íma. Mairamé asikakwáu i piri, aé ti upituú uwatá, uwatá uikú senundé kití, kutara retana. Unheẽ-ntu kwayé:

69 - "Ah! tu es là..."

69 - - Ah! Reikú iké... 
70 - Et il me prit par la main. Mais il se tourmenta encore:

70 - Aramé aé upisika se pú resé. Ma, amú í, upitá manduariwara:

71 - “Tu as eu tort. Tu auras de la peine. J'aurai l'air d'être mort et ce ne sera pas vrai..."

71 - - Kwá ti kurí puranga indé arã. Indé repurará. Remanduari kurí ixé amanũ aikú ma ti supisawa...

72 - Moi je me taisais.

72 - Aramé ixé akirirĩ.

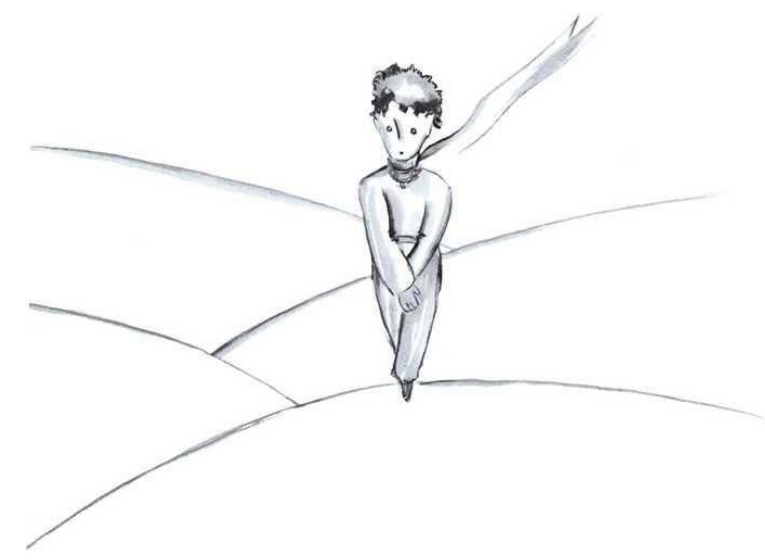

73 - "Tu comprends. C'est trop loin. Je ne peux pas emporter ce corps-là. C'est trop lourd."

73 - - Indé rekwáu. Se rapé apekatú retana. Ti arasú-kwáu se pira. Aé i pusé retana.

74 - Moi je me taisais.

74 - Ti anheẽ nẽ maã.

75 - "Mais ce sera comme une vieille écorce abandonnée. Ce n'est pas triste les vieilles écorces..."

75 - - Se pira kurí yepé mirá kwera pirera yawé. Mirá kwera pirera ti umusasiara nẽ awá.

76 - Moi je me taisais.

76 - Ixé rẽ aikuntu.

77 - Il se découragea un peu. Mais il fit encore un effort:

77 - Aé ukanhemu xinga i kirimbasawa. Ma unheẽ rẽ: 
78 - "Ce sera gentil, tu sais. Moi aussi, je regarderai les étoiles. Toutes les étoiles seront des puits avec une poulie rouillée. Toutes les étoiles me verseront à boire..."

78 - - Puranga kurí! Ixé yuíri amaã kurí yasitatá-itá resé. Panhẽ yasitatá kurí mayé ií-kwara yawé urikú waá-itá yepé ií-kwara wawakawara. Panhẽ yasitatá umupawa kurí se isisawa...

79 - Moi je me taisais.

79 - Ti rẽ anheẽ-kwáu nẽ maã.

80 - "Ce sera tellement amusant! Tu auras cinq cents millions de grelots, j'aurais cinq cents millions de fontaines..."

80 - - Kwá kurí surí retana! Indé rerikú kurí siía marakamirĩ, ixé arikú kurí siía ií-kwara...

81 - Et il se tut aussi, parce qu'il pleurait...

81 - Aramé aé yuíri ukirirĩ, nhaãsé uyaxiú uikú...

82 - "C'est là. Laisse-moi faire un pas tout seul."

82 - - Iké tendawa. Rexari ixé yepenhũ.

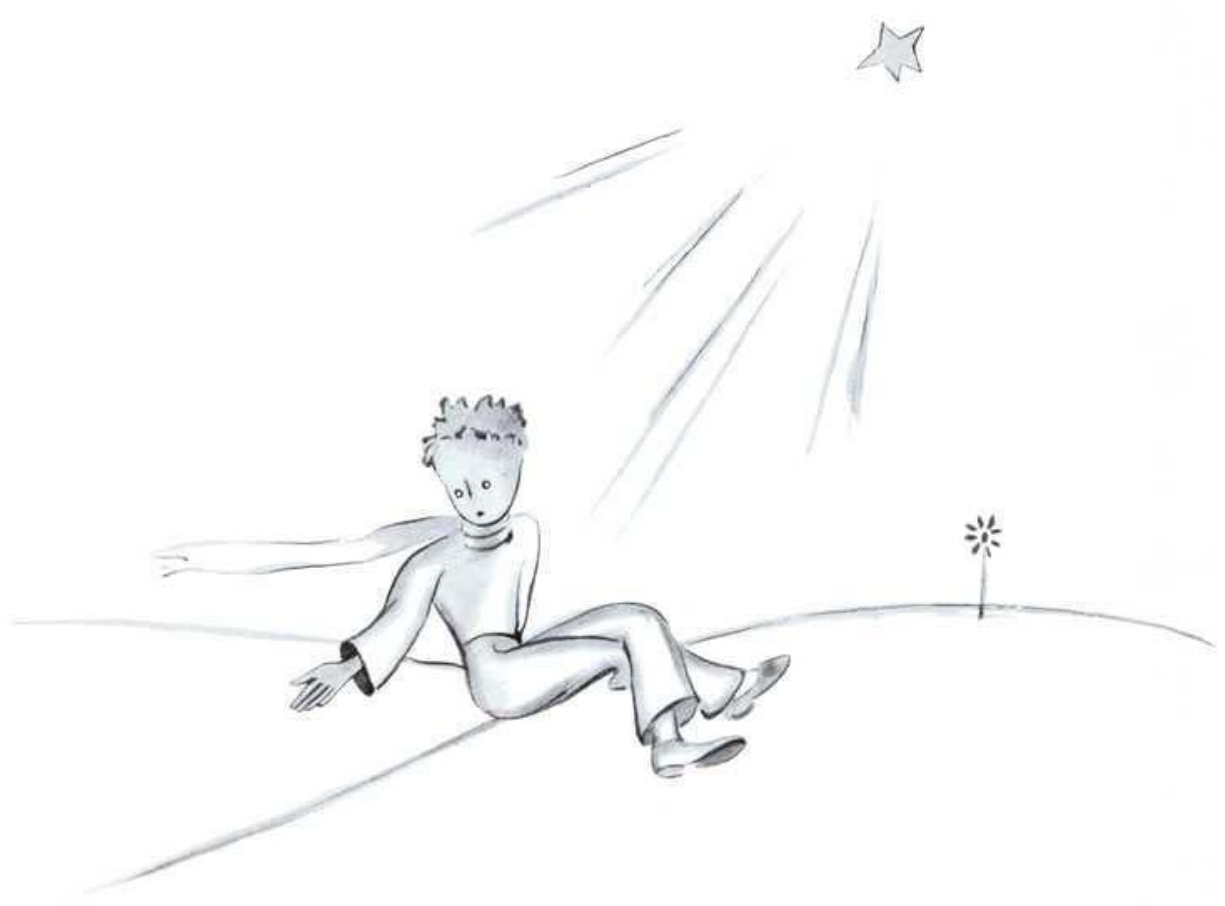

83 - Et il s'assit parce qu'il avait peur. Il dit encore:

83 - Aramé aé uwapika nhaãsé usikié. Asuí, unheẽ rẽ: 
84 - "Tu sais... ma fleur... j'en suis responsable! Et elle est tellement faible! Et elle est tellement naïve. Elle a quatre épines de rien du tout pour la protéger contre le monde..."

84 - - Indé rekwáu ana... se putira... arikuté apisirũ aé! Aé pitua retana! I piá i katú. Aé urikú irundí-ntu yú uyupisirũ arã...

85 - Moi je m'assis parce que je ne pouvais plus me tenir debout. Il dit:

85 - Awapika yuíri nhaãsé se kweré retana apuamu resewara aikú. Aramé aé unheẽ:

86 - "Voilà... C'est tout..."

86 - - Kwá kurí yawé tẽ...

87 - Il hésita encore un peu, puis il se releva. Il fit un pas. Moi je ne pouvais pas bouger.

87 - Aé rẽ usarú xinga, asuí upuamu. Uyupirũ uwatá. Ixé ti akataka-kwáu.

88 - Il n'y eut rien qu'un éclair jaune près de sa cheville. Il demeura un instant immobile. Il ne cria pas. Il tomba doucement comme tombe un arbre. Ça ne fit même pas de bruit, à cause du sable.

88 - Amaã yepé werasawa tawá setimã ruakí. Aé upitá mimi, ti ukataka. Aé yuíri ti usasemu. Asuí uwari merupí mayé yepé mirá kwera yawé. Iwikuí resewara, ti aikwé tiapú.

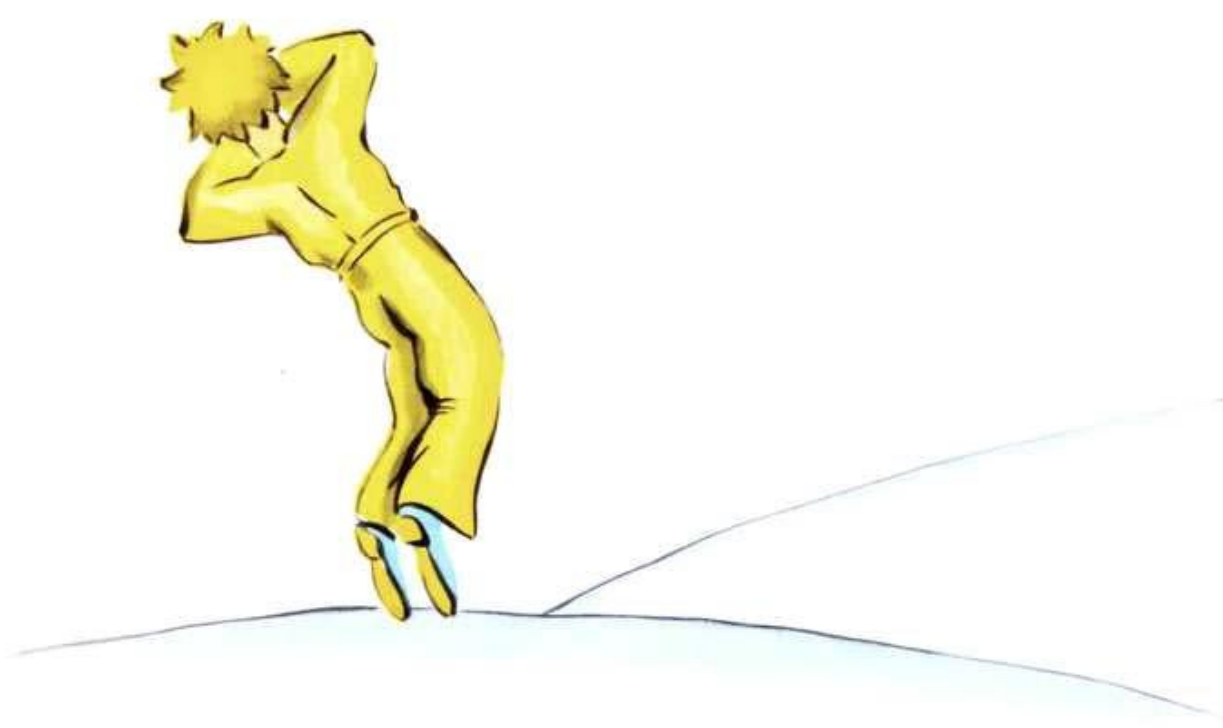


1 - Et maintenant bien sûr, ça fait six ans déjà... Je n'ai jamais encore raconté cette histoire. Les camarades qui m'ont revu ont été bien contents de me revoir vivant. J'étais triste mais je leur disais: "C'est la fatigue..."

1 - Nhaã ara suí, puyepé akayú uyusasá ana... Nẽ mairamé ambéu kwá mbeusawa nẽ awá supé. Se rumuara usuantí waá-itá ixé tá upitá surí mairamé tá umaã ixé se rikwé rẽ. Ixé sasiara aikú, ma anheẽ tá supé: "Se kweré..."

2 - Maintenant je me suis un peu consolé. C'est-à-dire... pas tout à fait. Mais je sais bien qu'il est revenu à sa planète, car, au lever du jour, je n'ai pas retrouvé son corps. Ce n'était pas un corps tellement lourd... Et j'aime la nuit écouter les étoiles. C'est comme cinq cents millions de grelots...

2 - Uií aikú ana puranga piri xinga. Ma, amuramé, apitá rẽ sasiara xinga. Akwáu tẽ aé uyuíri setama kití nhaãsé, mairamé nhaã ara i kwema, i pira ti ana uikú ape. I pira ti i pusé... Pituna ramé, asaisú asendú yasitatá-itá. Aintá mayé siía marakamirĩ yawé...

3 - Mais voilà qu'il se passe quelque chose d'extraordinaire. La muselière que j'ai dessinée pour le petit prince, j'ai oublié d'y ajouter la courroie de cuir! Il n'aura jamais pu l'attacher au mouton. Alors je me demande: "Que s'est-il passé sur sa planète? Peutêtre bien que le mouton a mangé la fleur...”

3 - Ma manungara amurupí retana usika. Se resarái amunhã yepé tupasama suú pirera suiwara mairamé akwatiari muruxauamirĩ supé suumé mimbira yurúpukwarisara! Aé nẽ mairamé upukwari-kwáu kurí aé suumé mimbira resé. Aramé apurandú: "Maã taá usika ana waá kwera setama upé? Araneíma tẽ suumé mimbira umbaú ana putira..."

4 - Tantôt je me dis: "Sûrement non! Le petit prince enferme sa fleur toutes les nuits sous son globe de verre, et il surveille bien son mouton..." Alors je suis heureux. Et toutes les étoiles rient doucement.

4 - Amuramé amanduari: “Akwáu tẽ ti kwayé! Muruxawamirĩ umburi muíri pituna i putira riruwasú sakakanga upé asuí umanhã-manhãna i suumé mimbira... Yawé ixé apitá surí, panhẽ yasitatá upuká seẽ.

5 - Tantôt je me dis: "On est distrait une fois ou l'autre, et ça suffit! Il a oublié, un soir, le globe de verre, ou bien le mouton est sorti sans bruit pendant la nuit..." Alors les grelots se changent tous en larmes!...

5 - Ma ixé yuíri amanduari: “Amuramé yamaã amú suaxara kití asuí manungara usika!" Aé sesarái ramé, yepé pituna, upisika riruwasú u ti ramé umaã suumé mimbira usú i suí pituna pukusawa..." Yawé panhẽ marakamirĩ uyeréu sesáyukisé!... 
6 - C'est là un bien grand mystère. Pour vous qui aimez aussi le petit prince, comme pour moi, rien de l'univers n'est semblable si quelque part, on ne sait où, un mouton que nous ne connaissons pas a, oui ou non, mangé une rose...

6 - Kwá manungara ti waá yakwáu kurí. Penhẽ arama, ixé arama yuíri, yasaisú waá muruxawamirĩ, iwaka pawa upitá amurupí yepé suumé mimbira ramé ti waá yakwáu, yepé tendawa upé, umbaú u ti umbaú yepé putira...

7 - Regardez le ciel. Demandez-vous: "Le mouton oui ou non a-t-il mangé la fleur?" Et vous verrez comme tout change...

7 - Pemaã iwaka kití. Pepurandú pe suí tẽ: "Suumé mimbira umbaú ana u ti umbaú putira?" Pemaã kurí mayé maã-itá upitá amurupí...

8 - Et aucune grande personne ne comprendra jamais que ça a tellement d'importance!

8 - Nẽ mairamé yepé mira turusú umaã kurí mayé kwá puranga!

9 - Ça c'est, pour moi, le plus beau et le plus triste paysage du monde. C'est le même paysage que celui de la page précédente, mais je l'ai dessiné une fois encore pour bien vous le montrer. C'est ici que le petit prince a apparu sur terre, puis disparu.

9 - Kwá sangawa, ixé arama, puranga piri asuí sasiara piri amaã ana waá. Kwá sangawa mayé sangawa senundewara yawé. Ma akwatiari aé amú í amukameẽ puranga arama penhẽ arama. Kwá tendawa upé, muruxawamirĩ uyukwáu Iwí upé, asuí ukanhemu.

10 - Regardez attentivement ce paysage afin d'être sûrs de le reconnaître, si vous voyagez un jour en Afrique, dans le désert. Et, s'il vous arrive de passer par là, je vous en supplie, ne vous pressez pas, attendez un peu juste sous l'étoile! Si alors un enfant vient à vous, s'il rit, s'il a des cheveux d'or, s'il ne répond pas quand on l'interroge, vous devinerez bien qui il est. Alors soyez gentils! Ne me laissez pas tellement triste: écrivez-moi vite qu'il est revenu...

10 - Pemaã katú kwá sangawa resé pemaã arama mamé upitá kwá tendawa, yepé ara ramé penhẽ pewatá yepé tetama mira-íma rupí África upé. Pesasá ramé mirupí, ayururéu pe suí ti pewatá kutara, pesarú xinga yepé yasitatá wírupi! Yepé kurumĩ uri ramé pe piri, aé upuká ramé, urikú ramé i awa itá-tawá yawé, ti ramé usuaxara mairamé amú awá upurandú manungara i suí, pekwáu kurí awá aé. Aramé, ayururéu tẽ pe suí: ti pexari ixé sasiara, penheẽ ixé arama aé uyuíri ana... 
$\checkmark$ 


\section{Tradução comentada}

\subsection{Do título: Muruxawamirĩ}

Como já foi dito em alusão à língua guarani, o título da obra de Saint-Exupéry apresenta um conceito de difícil tradução a esta língua, como também o é ao nheengatu. Se a palavra prince (príncipe) fosse traduzida por tuixawa (chefe) e, além disso, houvesse o interesse em evidenciar a posição hierárquica ocupada por um príncipe - o filho do rei -, o título da tradução em nheengatu poderia ser Tuixawa Rairamirĩ (Filhinho do Chefe). No entanto, como hoje em dia utiliza-se com muita frequência a palavra tuixawa para se referir à pessoa que desempenha um papel de liderança na comunidade em que vive ${ }^{77}$, preferi não utilizá-la a fim de evitar associações entre essa função e a designação dada a um jovenzinho que veio de outro planeta/asteroide à Terra. Assim, hesitando em assumir a mesma estratégia adotada pelos tradutores da obra ao guarani, por meio das possibilidades Tainamirĩ (Criancinha) ou Kurumimirĩ (Menininho), considerei como mais satisfatória a tradução Muruxawamirĩ ${ }^{78}$ (Chefinho). Muruxawa não é uma palavra utilizada nos dias atuais, mas já o foi em contextos em que nomes de cargos de lideranças políticas foram traduzidos ao nheengatu. Couto de Magalhães, como já se viu, traduziu “imperador" por muruxawa reté (chefe de fato) ${ }^{79}$. Sabe-se, contudo, que a utilização dessa palavra ocorreu em situações específicas, nas quais ou o tradutor tinha de recorrer a um empréstimo da língua portuguesa ou, como no caso referido, buscava se valer de uma palavra já existente na língua ${ }^{80}$, mas empregando-a em um sentido diferente do qual era originalmente empregado. A vantagem do uso da palavra muruxawamirĩ, a meu ver, frente às outras possibilidades,

\footnotetext{
${ }^{77}$ Há várias comunidades indígenas às margens do Rio Negro e, em cada uma delas, há um responsável por seus assuntos de interesse. A palavra utilizada em português para nomear essa função é "capitão", em nheengatu, tuixawa.

${ }^{78}$ Agradeço a Marcel Twardowsky Ávila pelas sugestões a respeito do título escolhido nesta proposta de tradução.

${ }^{79}$ Stradelli registra em seu dicionário as formas murutuixaua e muruxaua como "o chefe que manda" (2014, p. 431). Dom Frederico Costa abona muruixaua como "chefe supremo, general, rei" (1909, p. 200). O padre Constantino Tastevin considera muruxaua "grande chefe que delega o poder aos outros chefes subalternos" (1923, p. 108).

${ }^{80}$ A palavra muruxawa, em nheengatu, tem sua origem na palavra morubixaba, em tupi antigo, cuja etimologia é "chefe de gente", tendo sido empregada com os sentidos de "chefe tribal", "príncipe", "rei", "governador", "superior" e "senhor" (NAVARRO, 2013, p. 313).
} 
consiste em relacionar uma forma em desuso à nomeação de uma personagem misteriosa, da qual pouco se conhece e que aparece ao narrador no deserto, quase como uma miragem, longe de qualquer região habitada.

Com o intuito de não ancorar geograficamente a personagem no Rio Negro pela utilização da palavra tuixaua, o "preenchimento semântico" da palavra muruxaua pode ser auxiliado pelo primeiro desenho em que o principezinho é apresentado, no qual é retratado com uma longa capa, que possui ombreiras possivelmente de ouro, e portando uma espada, ou seja, trajando vestes características de um príncipe. No entanto, esse retrato, segundo o narrador, feito por ele algum tempo depois de ter conhecido o pequeno príncipe, parece ser fruto de sua lembrança difusa, através da qual reconstruiu afetivamente aos seus leitores a imagem dessa misteriosa criancinha, retratando-a como um principezinho, ainda que este não ocupe tal função e nem seja filho de um rei. Isso se fundamenta na comparação com os outros desenhos, nos quais o protagonista não aparece mais com a tal capa e com a espada e passa a ser apresentado com uma roupa simples que nada remete a vestes reais ${ }^{81}$. Algumas vezes, como nesse caso, as ilustrações, muito frequentes na obra de Exupéry, servirão de auxílio para tomadas de decisão.

\subsection{Da obra}

Nesta seção, quando me referir a algum excerto da tradução, mencionarei entre parênteses o número correspondente ao capítulo e à linha a que ele se refere; assim em C.1/L.1 leia-se "capítulo 1, linha 1". Ademais, para que os leitores tenham acesso ao conteúdo da tradução em nheengatu, farei a tradução do texto em nheengatu ao português. Esquematicamente, os fragmentos serão apresentados desta forma: texto em francês (texto-fonte, original) $\rightarrow$ texto em nheengatu (texto-meta, tradução) $\rightarrow$ texto em português (texto didático, tradução da tradução). Além disso, sempre que for necessário, traduzirei excertos diretamente do francês ao português para que os leitores possam

\footnotetext{
${ }^{81}$ Talvez também por isso os tradutores de Mitãmi optaram por tal título, corroborando a interpretação de que a função associada à palavra "príncipe" não se relaciona efetivamente com a personagem principal da obra.
} 
acompanhar as diferenças entre as traduções do francês ao português e do francês ao nheengatu $^{82}$.

\subsubsection{Estrangeirismos}

Nesta seção estão agrupados os empréstimos e os decalques da língua portuguesa ao nheengatu que utilizei em minha proposta de tradução. Apesar de a língua-fonte da tradução ser o francês, a grafia da língua portuguesa será utilizada nos empréstimos e decalques adotados por mim, visto que a maioria dos rionegrinos falantes maternos de nheengatu também o são de português, desconhecendo por completo a língua francesa. Com relação aos decalques, pode-se dizer que eles são os empréstimos que sofreram modificações para a conformação à grafia e às características fonéticofonológicas da língua de chegada, no caso o nheengatu. Muitos deles são decalques antigos da língua portuguesa, outros, porém, foram adaptados por mim em Muruxawamirĩ.

É válido ressaltar que as modalidades empréstimo e decalque relacionam-se somente à língua portuguesa; em relação ao francês, a modalidade adequada à descrição das traduções apresentadas nesta seção é a tradução literal, visto que em Muruxawamirĩ não há nenhum empréstimo ou decalque proveniente da língua francesa.

Ainda que a relação entre os idiomas envolvidos no processo tradutório seja do francês ao nheengatu, analisarei nesta seção a influência que o português exerceu em algumas escolhas lexicais presentes na tradução empreendida neste trabalho, a começar pelos empréstimos, recurso que utilizei principalmente na tradução de topônimos.

A tabela a seguir contempla todos os empréstimos oriundos do português adotados em Muruxawamiri:

\begin{tabular}{|l|l|l|}
\hline Le Petit Prince (FR) & O pequeno príncipe (PT) & Muruxawamiri (NHE) \\
\hline Chine & China & China (C.1/L.21) \\
\hline Arizone & Arizona & Arizona (C.1/L.21) \\
\hline Sahara & Saara & Saara (C.2/L.1) \\
\hline
\end{tabular}

82 Todas as traduções sem referência bibliográfica ao longo da análise são de minha autoria, as que não forem virão especificadas com a sua fonte. 


\begin{tabular}{|l|l|l|}
\hline Baobab & Baobá & Baobá (C.5/L.3) \\
\hline États-Unis & Estados Unidos & Estados Unidos (C.6/L.11) \\
\hline France & França & França (C.6/L.11) \\
\hline Réverbère & Lampião & Lamparina (C.14/L.2) \\
\hline Nouvelle-Zélande & Nova Zelândia & Nova Zelândia (C.16/L.4) \\
\hline Australie & Austrália & Austrália (C.16/L.4) \\
\hline Sibérie & Sibéria & Sibéria (C.16/L.5) \\
\hline Russie & Rússia & Rússia (C.16/L.6) \\
\hline Indes & Índia & Índia (C.16/L.6) \\
\hline Afrique & África & África (C.16/L.6) \\
\hline Europe & Europa & Europa (C.16/L.6) \\
\hline Lampe & Lâmpada; Candeeiro & Lamparina (C.24/L.32) \\
\hline Nöel & Natal & Natal (C.25/L.15) \\
\hline
\end{tabular}

\section{Tabela 1: Empréstimos do português adotados em Muruxawamirĩ}

Sobre os topônimos, inicialmente cogitei a possibilidade de adaptá-los ao nheengatu, como em Turukia, Sitatu Unitu, Furansa e Eurupa, que traduziriam respectivamente: Turquia, Estados Unidos, França e Europa. No entanto, optei por não alterar a grafia do português nesses casos, porque, devido à quantidade de topônimos que aparecem no livro, seria muito custoso e artificial para adaptá-los e para que os leitores os entendessem. Como a língua portuguesa é falada na maior parte da Amazônia, julguei mais adequado não alterar a grafia de tais palavras.

No caso da palavra réverbère, que se traduz ao português por "lampião", a opção por utilizar o empréstimo "lamparina" atendeu à sugestão da professora Celina Menezes da $\mathrm{Cruz}^{83}$, que em comunicação pessoal sugeriu que eu utilizasse a palavra "lamparina", mais comum aos falantes de nheengatu do que a palavra "lampião". Isso se comprova também no C.24/L.32 com a tradução da palavra lampe, que nesse contexto também foi traduzida por "lamparina". O conde italiano Ermanno Stradelli registrou em seu dicionário a forma candêa-ireru, que literalmente se traduz por "vasilha de candeia", e que serviria à tradução de "lamparina", "candeeiro" (2014, p. 243 e 335). No entanto,

83 A professora Celina, falante bilíngue de nheengatu e português, ajudou-me gentilmente no refinamento da tradução e na escolha de palavras em nheengatu mais adequadas a cada contexto. 
como tal construção foi refutada pelos falantes de nheengatu a que tive acesso, o uso de "lamparina" foi adotado em minha tradução.

Passando agora aos decalques, estão listados na tabela a seguir todos os que foram empregados em Muruxawamirĩ :

\begin{tabular}{|c|c|c|}
\hline Le Petit Prince (FR) & O pequeno príncipe (PT) & Muruxawamirĩ (NHE) \\
\hline Livre & Livro & Papera (C.1/L.1) \\
\hline Chapeau & Chapéu & Xapewa (C.1/L.8) \\
\hline Éléphant & Elefante & Erepanti (C.1/L.10) \\
\hline Papier & Papel & Papera (C.2/L.28) \\
\hline Jupiter & Júpiter & Yupiteri (C.4/L.3) \\
\hline Mars & Marte & Máriti (C.4/L.3) \\
\hline Vénus & Vênus & Wénusi (C.4/L.3) \\
\hline Turc & Turco & Turquiawara (C.4/L.9) \\
\hline Européenne & Europeia & Europawara (C.4/L.9) \\
\hline Habiter & Morar & Murari (C.4/L.26) \\
\hline Tromper & Enganar & Ganani (C.4/L.40) \\
\hline Minute & Minuto & Minutu (C.6/L.12) \\
\hline Boulon & Parafuso & Beruma (C.7/L.8) \\
\hline Tousser & Tossir & Tusé (C.8/L.27) \\
\hline Banque & Banco & Banku (C.13/L.50) \\
\hline Foulard & Echarpe & Panu pisãwéra (C.13/L.49) \\
\hline Semaine & Semana & Sumana (C.13/L.57) \\
\hline Mouchoir & Lenço & Panu (C.14/L.19) \\
\hline Électricité & Eletricidade & Itirisitati (C.16/L.3) \\
\hline $\begin{array}{l}\text { Amérique } \mathrm{du} \quad \mathrm{Sud} ; \\
\text { Amérique du Nord }\end{array}$ & $\begin{array}{l}\text { América do Sul; América } \\
\text { do Norte }\end{array}$ & América-itá (C.16/L.6) \\
\hline Pôle Nord; Pôle Sud & Polo norte; Polo sul & Polo-itá (C.16/L.7) \\
\hline Marchand & Comerciante, Negociante & Venderisara (C.23/L.2) \\
\hline Vendre & Vender & Venderi (C.23/L.4) \\
\hline Saharien & Saariano & Saarawara (C.25/L.4) \\
\hline
\end{tabular}




\begin{tabular}{|l|l|l|}
\hline Cache-nez & Cachenê & Panu (C.26/L.16) \\
\hline
\end{tabular}

Tabela 2: Decalques em nheengatu, oriundos do português, adotados em Muruxawamirĩ

Entre esses registros, há termos que são utilizados há muito tempo em nheengatu, como é o caso dos verbos murari e ganani, decalques de "morar" e “enganar". O verbo "morar”, que originalmente era uma das acepções do verbo ikú (estar; viver, morar), também passa a ser visto sob a forma morari em Costa (1909, p. 235) e em Tastevin (1923, p. 100) e morári em Stradelli (1929/2014, p. 253). Nessas mesmas obras, a forma ganani é abonada. Assim, há evidências concretas de que pelo menos desde o começo do século XX esses decalques provenientes da língua portuguesa já são notados em nheengatu. Além desses verbos, os substantivos papera e xapewa, formas adaptadas de "papel” e "chapeú", também são encontrados há muitos anos na bibliografia sobre o nheengatu. Magalhães registra papéra como "carta", "papel” e "livro" (1975, 1' parte, p. 101 e 162), Costa abona papêra com os sentidos de "papel", "livro" e "folha" (1909, p. 202), Tastevin considera papera apenas com o sentido de "papel" (1923, p. 114) e Stradelli traduz "livro" e "papel" como papera (1929/2014, pp. 245 e 265). Para “chapéu”, por sua vez, Costa registrou chapeua (1909, p. 220), Tastevin anotou xapéwa (1923, p. 142) e Stradelli, xapéua (1929/2014, p.186).

Além desses, o empréstimo adaptado panu, oriundo de "pano", encontra-se na literatura sobre o nheengatu há muito tempo. Stradelli grafou as formas pana e pánu com o sentido de "pano, tela, tecido", as quais atribuiu a seguinte explicação: "é o nome genérico que é dado a toda e qualquer espécie de tecido que se encontra nas lojas e é trazido pelos civilizados. Os tecidos indígenas não têm, pelo geral, nome genérico" (1929/2014, p. 448). Costa (1909) e Tastevin (1923) também anotaram em seus glossários, com diferenças sutis de grafia, a utilização dessa palavra, que há muito tempo, como apontado por Stradelli, é empregada de forma genérica. Em Muruxawamirĩ utilizei $\operatorname{panu}^{84}$ na tradução de três termos em francês: foulard (echarpe), mouchoir (lenço) e cache-nez (cachenê). Para que a tradução fosse satisfatória, foi imprescindível relacionar a palavra panu com outras ao seu entorno, ou mesmo associálas com ilustrações do livro. No C.13/L.49, como é dito que a echarpe é algo que se põe ao redor do pescoço, ao traduzir foulard por panu pisãwéra (pedaço de pano), foi

\footnotetext{
${ }^{84}$ Optei pelo registro panu à forma pana porque hoje em dia, no Rio Negro, pronuncia-se essa palavra tal qual "pano", em português.
} 
possível recuperar a especificidade desse tecido na continuidade da tradução, em que se diz amburi-kwáu aé se ayura resé (posso colocá-lo em meu pescoço). Mouchoir (C.14/L.19), por sua vez, aparece em um contexto específico, no qual o acendedor de lampiões enxuga sua testa num lenço de losangos vermelhos, cuja tradução ficou: ariré umutikanga i siwá yepé panu piranga irumu (depois secou sua testa com um pano vermelho). Por fim, no C.26/L.16, no contexto em que o narrador diz que desatou o cachenê que o principezinho sempre usava, adicionei a cache-nez uma informação que explica que esse tipo de tecido é utilizado para cobrir o pescoço ${ }^{85}$ : ayurari panu kitanga aé ururiwera waá i ayura resé (afrouxei o nó do pano que ele era acostumado a levar em seu pescoço). Associado a essas palavras, há no livro dezessete ilustrações que mostram o pequeno príncipe utilizando um lenço comprido ao entorno de seu pescoço.

Um caso curioso é o da palavra beruma. Em comunicação pessoal perguntei à professora Celina Menezes da Cruz se ela utilizava ou se lembrava de alguma palavra que servia à tradução de "parafuso" e obtive a resposta de que hoje em dia não há uma palavra que a traduza, mas que ela se lembrava de seu pai e de outros falantes mais velhos utilizarem a palavra beruma para designar qualquer objeto perfurante com formato espiralado. Esse termo é o decalque da palavra "verruma", da língua portuguesa, que segundo o dicionário digital Caldas Aulete é uma "ferramenta aguçada, com ponta em forma de hélice, usada para furar madeira" (AULETE, 2017). Ainda que beruma não seja um termo utilizado pelos atuais falantes de nheengatu, decidi resgatar esse decalque antigo da língua portuguesa, cujo significado pode ser apreendido no contexto em que se insere, como no C.7/L.8 e L.17, em que a palavra beruma (parafuso) aparece associada às palavras mukatakasara (motor) e petekasara (martelo).

Outros registros, porém, são decalques mais recentes, como, por exemplo, venderisara, formado pelo verbo venderi (vender) junto do sufixo -sara (-(d)or; aquele que), que literalmente se traduz por "vendedor" ou "aquele que vende". Além dessa palavra, o decalque trukarisara (trukari (trocar) + -sara (-(d)or)) também pode ser utilizado em alguns contextos para traduzir "vendedor", embora traga da língua portuguesa o sentido do verbo "trocar". Optei, assim, por utilizar venderisara e venderi em Muruxawamirĩ para deixar claro que o contexto em que se inserem é o de compras e

\footnotetext{
${ }^{85}$ Ainda que cachenê, segundo o dicionário digital Caldas Aulete, seja uma "faixa comprida de tecido usada como agasalho em volta do pescoço e cobrindo até o nariz" (AULETE, 2017), preferi não relacionar o uso dessa vestimenta com a palavra "nariz".
} 
vendas remuneradas, e não o de trocas. Outro decalque decorrente da língua portuguesa é o verbo tusé (tossir) ${ }^{86}$. Em tupi antigo emprega-se na tradução de "tossir" o termo $u$ 'u (NAVARRO, 2013, p. 504), mas, como em nheengatu esse registro não é mais utilizado e compreendido, carecendo a língua de uma palavra que traduza esse verbo, optei pelo emprego da forma tusé (tossir), utilizada nos dias atuais.

De modo semelhante, em algumas situações optei por associar um elemento gramatical do nhenegatu a uma palavra emprestada do português, como em Turquiawara, Europawara e Saarawara, traduzidos respectivamente por "turco(a)", "europeu(eia)" e "saariano(a)"87. O sufixo -wara pode ser traduzido ao português pelo sufixo "-al", por exemplo em iwakawara, cuja traducão é "celestial” ou "o que é do ceú”. Também é utilizado para indicar a proveniência de uma pessoa, como em ikewara (o que é daqui), de iké "aqui" e -wara (o que é de), assim se mũ ikewara se traduz por "meu irmão é daqui" ou "meu irmão é habitante daqui". Esse sufixo é encontrado em alguns gentílicos da língua portuguesa, como manauara (o que é de Manaus) e tapajoara (o que é do rio Tapajós).

Além desses exemplos, também se percebe o emprego do morfema -itá, que marca o plural, nas formas América-itá e Polo-itá, nas quais, agrupei a referência ao norte e ao sul em uma única palavra. Esse morfema, no decorrer do livro, também aparece com as palavras "baobá" e "lamparina". Inicialmente pensei em adaptar a referência aos baobás à realidade amazônica. No entanto, não foi possível estabelecer uma relação que mantivesse alguns dos traços semânticos importantes que caracterizam essa árvore. O baobá é uma árvore africana que pode atingir até 20 metros e possui tronco extremamente largo, onde armazena água (AULETE, 2017). Ademais, como no livro é contado que os baobás podem rebentar o solo de um planeta, principalmente se há muitos deles em um lugar pequeno, como no asteroide do pequeno príncipe, talvez eu pudesse ter associado o porte dessa árvore com o da samaúma, uma árvore de grande porte encontrada na Amazônia. Contudo, como a samaúma possui raízes tabulares muito grandes, diferentemente dos baobás, que não possuem raízes desse tipo, e pelo fato de haver no livro uma ilustração dos baobás (C.5), preferi não adaptar baobá a samaúma porque, se assim o fizesse, provocaria uma contradição entre a designação da árvore e a sua representação imagética.

\footnotetext{
${ }^{86}$ Ainda que a grafia seja tusé, a pronúncia desse verbo é "tusê".

${ }^{87} \mathrm{Em}$ nheengatu não há morfologia específica que estabeleça distinção entre gêneros.
} 
Por fim, algumas palavras foram adaptadas exclusivamente para a tradução deste trabalho, como Yupiteri, Máriti, Wénusi, sumana, banku, minutu, itirisitati e erepanti. Algumas delas aparecem apenas uma vez no livro, outras, porém, são repetidas várias vezes, como é o caso da palavra éléphant. A primeira ocorrência dessa palavra se dá no C.1/L.10:

\section{Il représentait un serpent boa qui digérait un éléphant.}

\section{Aé umukameẽ yepé buyawasú i apú waá erepanti kwera resewara.}

(Ele representava uma jiboia que estava cheia por causa de um elefante.)

Nesse excerto o narrador conta que as pessoas adultas nunca compreendiam os desenhos que ele fizera em sua infância e que era sempre necessário dar-lhes explicações para que pudessem entendê-los. Em minha primeira tradução não utilizei o decalque erepanti, traduzi essa sentença por: Aé umukameẽ yepé buyawasú $i$ apú waá ximbiú kwera turusú resewara (Ele mostrava uma jiboia que estava cheia por causa de sua grande ex-presa). Em uma tradução literal ao português, ximbiú kwera turusú é "sua grande comida/refeição", mas, dentro desse contexto, o elefante, que é uma grande presa, digerido pela jiboia, torna-se uma grande ex-presa, uma grande presa que "já era" ${ }^{\sharp 8}$. Como no capítulo 1 há uma ilustração que mostra um elefante dentro de uma jiboia, sendo digerido por ela, a associação entre éléphant e ximbiú kwera turusú seria muito proveitosa. Contudo, como a palavra éléphant, além dessa ocorrência, aparece mais quatro vezes, em contextos diferentes, em que "elefante" não está mais associado à ideia de uma grande presa sendo digerida (como no C.5/L.12, em que se faz referência a uma manada de elefantes), procurei uma solução que se adquasse a todas as situações do livro, assim optei pela utilização do decalque erepanti.

\subsubsection{Neologismos}

Um dos recursos mais empregados na tradução de Muruxawamirĩ, a fim de se evitar o uso ostensivo da língua portuguesa e aumentar as possibilidades lexicais da

\footnotetext{
${ }^{88} \mathrm{O}$ termo kwera, do nheengatu, é oriundo do adjetivo pûer, do tupi antigo, cujo significado é "extinto", "morto", "que já era", encontrado em composições como Ibirapuera (de ybyrá + pûer + -a: "árvore(s) velha(s)") (NAVARRO, 2013, p. 566).
} 
língua de chegada, foi a utilização de palavras em nheengatu em novas associações semânticas, nas situações de falta de correspondência entre os códigos e culturas envolvidos na tradução. Embora nesta seção estejam agrupados os neologismos, em algumas escolhas lexicais estarão associadas outras modalidades de tradução, como o resgate de palavras antigas e circunlóquios. Eis alguns dos neologismos propostos:

- Iwí-kwausawa, mirasawa-itá marandua, paparisawa e yané nheenga (geografia, história, cálculo e gramática)

No C.1/L.14, as palavras géographie, histoire, calcul e grammaire, que aparecem em um contexto de nomeação de áreas do saber, de disciplinas estudadas na escola, foram respectivamente traduzidas por iwí-kwausawa (conhecimento da terra), mirasawa-itá marandua (história das gerações), paparisawa ${ }^{89}$ (conta) e yané nheenga (nossa língua ${ }^{90}$. Embora seja questionável a classificação de paparisawa e yané nheenga como neologismos, pelo fato de o primeiro nome, um deverbal de papari (contar), ser utilizado para traduzir "conta", "cálculo" e "número", e o segundo ser um termo muito genérico para se referir ao estudo da estruturação de uma língua, optei por classificá-los como neologismos pelo fato de não serem utilizados para a nomeação das disciplinas escolares cálculo/matemática e gramática.

\section{- Iwí-kwausara (geógrafo)}

Relacionado à disciplina de geografia, outro neologismo aparece no C.15, no momento em que o pequeno príncipe chega ao planeta habitado por um velho que escrevia livros enormes. Na L.6 desse capítulo, diz o velho:

- Je suis géographe, dit le vieux monsieur.

- Ixé yepé iwí-kwausara - unheẽ tuyué.

\footnotetext{
89 Paparisawa, além de traduzir "conta" nas acepções de "cálculo" e "adição", também traduz a palavra "número", empregada várias vezes na tradução.

${ }^{90}$ Agradeço a Marcel Twardowsky Ávila pela ajuda na escolha desses termos.
} 
(- Eu sou ${ }^{91}$ um conhecedor da terra - disse $\mathrm{o}^{92}$ velho.)

E, após ser indagado pelo principezinho com a pergunta "O que é um geógrafo?”, o velho responde (C.15/L. 8):

- C'est un savant qui connaît où se trouvent les mers, les fleuves, les villes, les montagnes et les déserts.

- Iwí-kwausara yepé mira ukwáu waá mamé upitá paranãwasú-itá, paranãitá, tawa-itá, iwitera-itá asuí tetama-itá mira-íma.

( $\mathrm{O}$ conhecedor da terra é uma pessoa que sabe onde ficam os mares ${ }^{93}$, rios, aldeias, serras e regiões sem gente.)

Esse esclarecimento ajuda o pequeno príncipe e, consequentemente, os leitores do livro a compreender a área de saber em que um geógrafo atua, um conhecedor das características físicas de um lugar. A relação entre "geografia", o campo de estudo, e "geógrafo", a profissão, se efetua em nheengatu com a utilização dos sufixos -sawa e sara acoplados à base verbal kwáu (saber, conhecer; ser capaz). O sufixo-sawa é muito produtivo em nheengatu, utilizado para a formação de substantivos, assim kwausawa (conhecimento) é a forma nominal do verbo kwáu. O sufixo -sara, por sua vez, justaposto a um verbo, indica a pessoa que executa uma ação ou o instrumento utilizado em sua realização, formando, assim, um substantivo com características agentivas: kwausara (aquele que conhece, conhecedor). Ambas as palavras, antecedidas do substantivo iwí (terra, chão), estabelecem com ele uma relação genitiva ${ }^{94}$, assim obtêmse iwí-kwausawa (conhecimento da terra) e iwí-kwausara (conhecedor da terra).

\footnotetext{
${ }^{91}$ Em nheengatu não há o verbo "ser", sua utilização nas traduções do nheengatu ao português visou apenas à fluência da leitura em português.

92 Em nheengatu também não há artigos definidos, com a mesma justificativa da nota anterior eles serão utilizados nas traduções ao português.

93 Literalmente paranãwasú, cujo significado é "riozão" ou "rio grande", não traduz "mar". Por exemplo, o rio Negro, assim como outros rios volumosos, é chamado de paranãwasú. No entanto, por extensão semântica, essa é a palavra utilizada na tradução de "mar".

94 Em português a relação genitiva é estabelecida pelo intermédio da preposição "de" entre dois substantivos, como em "cabeça do menino". Em nheengatu, como em inglês e alemão, essa relação se dá pela anteposição do termo determinante ao termo determinado, sem o uso de preposição. Assim, "cabeça do menino" em nheengatu traduz-se por kurumĩ akanga, literalmente "menino cabeça".
} 


\section{- Suumé mimbira e suumé waimĩ (cordeiro e ovelha)}

A palavra mouton (cordeiro) foi traduzida por suumé mimbira. Soomé e somé são as formas que Ermanno Stradelli utilizou em seu dicionário para traduzir "ovelha" (1929/2014, p. 262). Suumé, forma adaptada à grafia adotada neste trabalho, é uma construção onomatopaica composta por suú (animal) e mé, som emitido pela ovelha. Esta é uma criação lexical que apenas se observa no dicionário de Stradelli ${ }^{95}$ e que os falantes atuais de nheengatu desconhecem.

Em trabalho de campo realizado em São Gabriel da Cachoeira, a professora Celina Menezes da Cruz relatou-me que pessoas mais velhas se referiam de forma genérica a animais quadrúpedes de porte inferior ao dos bois e vacas pelo termo tapiiramirĩ, literalmente "boizinho". Assim, traduzi inicialmente mouton por tapiiramirĩ mimbira, uma relação genitiva que traz a palavra mimbira (filhote) associada à designação genérica tapiiramirĩ. No entanto, como tapiira (boi) é palavra utilizada hoje em dia, preferi, a fim de evitar associações indevidas entre o boi e o cordeiro, traduzir por suumé mimbira o nome atribuído a este animal, cuja tradução literal é "filhote do animal "mé"”. A retomada de um termo cunhado por Stradelli associado à palavra mimbira traduz "cordeiro" no sentido de que este animal é o filhote do carneiro e da ovelha, animais que emitem um som característico.

No enredo de Le Petit Prince, após o principezinho pedir insistentemente ao aviador que lhe desenhasse um cordeiro, encontramos esta passagem (C.2/L.40):

“Tu vois bien... ce n'est pas un mouton, c'est un bélier. Il a des cornes..."

- Rekwáu tẽ kwá ti yepé suumé mimbira. Kwá yepé suumé waimĩ. Aé urikú i aka-itá.

(- Você sabe mesmo que isto não é um filhote de ovelha. Isto é uma ovelha velha. Ela tem chifres.)

\footnotetext{
${ }^{95}$ É válido ressaltar que em tupi antigo a forma sygûasumẽ, traduzindo "cabra, mamífero ruminante", foi utilizada pelo padre José de Anchieta em sua obra poética (NAVARRO, 2013, p. 450). O conde Ermanno Stradelli, em seu dicionário nheengatu/português, registra como "cabra" a palavra suasumé (1929/2014, p. 483). Sygûasu e sûasu, em tupi antigo, e suasú, em nheengatu, traduzem "veado, cervo". Assim, em ambos os casos a tradução literal das formas sygûasumẽ e suasumé seria "veado mé", "veado (que emite o som) mé".
} 
Nela, observamos que a diferença entre suumé mimbira (filhote de ovelha) e suumé waimĩ (ovelha velha) é estabelecida pela constatação de que o último possui chifres e o primeiro não. Sabe-se que alguns ovinos - carneiros e ovelhas - têm chifres, e alguns deles, como os selvagens, possuem chifres que podem chegar a mais de um metro de comprimento, o que se observa apenas em sua fase adulta. Assim, marcando esse estágio com a palavra waimĩ (velha), estabelece-se a diferença entre os ovinos velhos e seus filhotes.

Tais animais são parentes próximos dos caprinos - bodes e cabras -, que também apresentam chifres, talvez por isso Dom Marcos Barbosa tenha feito a seguinte escolha na tradução do excerto supracitado ao português:

- Bem vês que isto não é um carneiro. É um bode... Olha os chifres... (SAINTEXUPÉRY/BARBOSA, 1975, p. 14)

Nessa tradução, mouton, cujo significado, segundo o dicionário digital Michaelis - francês/português (MICHAELIS, 2017), é “cordeiro", foi traduzido por "carneiro" e bélier, que segundo o mesmo dicionário é o "carneiro selvagem, não castrado", foi traduzido por "bode" 96 .

Como na tradução Muruxawamirĩ resgatei uma criação lexical desconhecida pelos falantes de nheengatu, a utilização de uma nota de rodapé na primeira ocorrência da palavra suumé se mostrou uma boa estratégia para explicar aos leitores a característica desse animal. Dessa forma no C.2/L.10 utilizei a nota yepé suú i nheenga waá "mé”, que se traduz por "um animal cuja voz é 'mé”".

\section{- Yasitatá-maãsára e yasitatá-sikarisara (telescópio e astrônomo)}

No C.4/L.3 a tradução da palavra télescope, que em nheengatu ficou yasitatámaãsára (aquilo que olha as estrelas, observador das estrelas), traz no nome a especificidade do instrumento utilizado para a observação dos astros, por meio do qual os astrônomos realizam as suas descobertas. Nesse nome emprega-se o sufixo -sara ao

\footnotetext{
${ }^{96} \mathrm{~A}$ mesma escolha foi adotada nas demais traduções ao português a que tive acesso: BARBOSA (2008, p. 12), GULLAR (2013, p. 88), BETTO $(2015$, p. 16) e LIMEIRA (2015). Apenas em BETTO $(2015$, p. 16) mouton foi traduzido por "ovelha" em vez de "carneiro".
} 


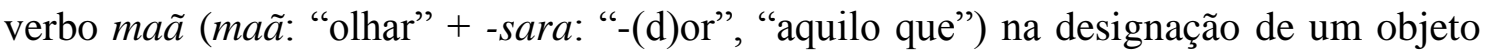
utilizado para olhar, e realiza-se a relação genitiva entre os substantivos yasitatá (estrela) e maãsára (olhador, aquilo que olha).

No C.4/L.4 astronome foi traduzido por yasitatá-sikarisara (aquele que procura as estrelas, pesquisador das estrelas) ${ }^{97}$. Nesse neologismo o sufixo -sara foi utilizado para designar a profissão ou o hábito da pessoa que realiza a ação de procurar (sikari: "procurar" + -sara: “-(d)or”, “aquele que”). Bem como em yasitatá-maãsára, em yasitatá-sikarisara estabeleceu-se a relação genitiva entre os substantivos que formam a nova composição lexical.

Os dois termos cunhados têm a sua interpretação facilitada pela primeira ilustração do capítulo 4, na qual se vê o desenho de um telescópio e de um homem que olha através dele, o astrônomo.

\section{- Iwaka-retama (planeta/asteroide)}

Ainda em relação aos astros, de sua observação por meio de um instrumento ou da profissão de quem se ocupa de identificá-los, no C.3/L.13 aparece pela primeira vez a palavra planète (planeta), cuja tradução oscilou bastante durante todo o processo de tradução.

Considerando que o lugar de onde veio o principezinho é chamado de asteroide, planeta ou estrela, primeiramente pensei em descrever em algumas palavras o que seria um asteroide, traduzindo-o assim por tendawamirĩ iwaka kití (lugarzinho para os lados do céu). No entanto, tal descrição deixaria a leitura do texto muito enfadonha, visto que somente a palavra astéroïde (asteroide) aparece nove vezes no livro. Além disso, se optasse por traduzir planète (planeta) por tendawa iwaka kití (lugar para os lados do céu), diferenciando-o assim de tendawamirĩ iwaka kití apenas pela supressão do sufixo de grau diminutivo - mirĩ, essa escolha se mostraria ainda mais malsucedida, pelo fato de a palavra planète aparecer sessenta e sete vezes no livro. Dessa forma, analisando a maioria das referências aos planetas e asteroides encontradas no livro e levando em conta principalmente este excerto (C.26/L.37):

\footnotetext{
${ }^{97}$ Agradeço a Marcel Twardowsky Ávila pela sugestão desse termo.
} 
“Cette nuit, ça fera un an. Mon étoile se trouvera juste au-dessus de l'endroit où je suis tombé l'année dernière..."

- Kwá pituna ramé, aikwé ana yepé akayú asika waá iké. Se yasitatá uikú kurí tendawa árupi mamé asika akayú kwera ramé...

(- Nesta noite já faz um ano que cheguei aqui. Minha estrela estará sobre o lugar onde cheguei no ano passado...)

julguei ser possível traduzir "asteroide" por yasitatá (estrela), porque o próprio principezinho referiu-se ao seu asteroide, o asteroide B 612, como sendo uma estrela. Além disso, como "asteroide" e "planeta" são palavras utilizadas como sinônimos ao longo do livro, achei plausível, por ter traduzido astéroïde por yasitatá, também traduzir planète por yasitatá. A diferença entre planeta e asteroide seria estabelecida, quando necessário, pelo acréscimo do sufixo - wasú (-ão) ao primeiro e do sufixo -mirĩ (-inho) ao segundo. No entanto, tal solução esbarrou em mais uma dificuldade.

Em algumas passagens em que a palavra étoile (estrela) aparece, o uso de yasitatá, que em nheengatu traduz "estrela", mas que como se viu também seria utilizada para traduzir "asteroide" e "planeta", não traria precisão à tradução, como se vê no C.10/L.28:

Le roi d'un geste discret désigna sa planète, les autres planètes et les étoiles.

(O rei, com um gesto discreto, indicou seu planeta, os outros planetas e as estrelas.)

Nesse caso, se optasse por traduzir planète por yasitatá, a distinção entre "planeta" e "estrela" não seria estabelecida. Isso geraria confusão em algumas passagens, como no C. 13, quando o pequeno príncipe pergunta ao empresário o que eram as coisas no céu que este passava a vida a contar. Mas este, por ser um homem sério e muito ocupado, não prestava atenção às curiosidades do principezinho, que após várias tentativas descobre que o que se contava eram as estrelas (C.13/L.20-22):

- Mais non. Des petites choses dorées qui font rêvasser les fainéants. Mais je suis sérieux, moi! Je n'ai pas le temps de rêvasser. 
(- Também não. Essas coisinhas douradas que fazem sonhar os preguiçosos. Mas eu sou um homem sério! Não tenho tempo para divagações.)

- Ah! des étoiles?

(- Ah! Estrelas?)

- C'est bien ça. Des étoiles.

(- Isso mesmo. Estrelas.)

Nessa situação, em que a referência se faz explicitamente às estrelas, o uso expandido de yasitatá, referindo-se a planetas, asteroides e estrelas, poderia gerar dúvida nos leitores, que estariam interpretando yasitatá como qualquer corpo celeste e não especificamente como estrela.

A solução para esse problema apareceu na passagem em que o principezinho pergunta ao aviador se ele tinha caído do céu, porque o seu avião (objeto que o pequeno príncipe nunca tinha visto) estava no deserto, devido ao pouso forçado que ele fizera por causa de uma pane no motor. Um pouco após o aviador explicar ao principezinho que ele voava naquele objeto, o pequeno lhe faz o seguinte questionamento (C.3/L.13):

"Alors, toi aussi tu viens du ciel! De quelle planète es-tu?"

- Aramé, indé yuíri reyuri iwaka suí! Maã iwaka-retama suí indé reyuri?

(- Então, você também vem do céu! De que região do céu você vem?)

Nesse excerto, em que a primeira ocorrência de planète aparece, tentei explicar o que seria entendido por planeta, um corpo celeste como a Terra, onde hipoteticamente outras pessoas poderiam habitar, assim decidi traduzir planète por iwaka-retama (região do céu). A palavra tetama, que se traduz ao português por "terra, região; pátria", é uma palavra pluriforme que tem sua forma alterada a retama quando associada a outro substantivo, como na relação genitiva iwaka-retama (iwaka: "céu"; retama: "região"), ou a um pronome possessivo, (se retama: "minha região"; ne retama: "tua região"...), exceto o pronome possesivo de terceira pessoa do singular, que receberá o prefixo $s^{-}$, assim setama traduz-se por "sua terra; terra dele". Quando a palavra tetama não é 
determinada por um substantivo ou por um pronome possessivo, ela aparece em sua forma absoluta, com o prefixo $t$-, como em tetama puranga "região bonita"98.

A escolha de iwaka-retama é corroborada na fala do aviador, após ele receber com muito espanto a pergunta do principezinho, mencionada anteriormente (C.3/L.15):

"Tu viens donc d'une autre planète?"

- Reyuri yepé tetama suí ti waá upitá Iwí upé?

(- Você vem de uma região que não fica na Terra?)

Desse modo, "outro planeta" foi traduzido pelo circunlóquio "região que não fica na Terra", para assim facilitar a interpretação de que há regiões habitadas que não se situam no planeta Terra, assim essas regiões seriam os outros planetas. Como o asteroide de onde o pequeno príncipe veio é uma região que não fica na Terra e por ele ser chamado muitas vezes de planeta, optei também por traduzir astéroïde por iwakaretama. Em algumas ocorrências, contudo, não foi necessário repetir integralmente a composição iwaka-retama. Quando a referência à região de origem do pequeno príncipe já tinha sido estabelecida, pude traduzir planète ou astérö̈de apenas por tetama (retama, setama), deixando dessa forma a leitura mais fluida, como neste exemplo (C.4/L.5), no qual a repetição de iwaka-retama seria desnecessária:

J'ai de sérieuses raisons de croire que la planète d'où venait le petit prince est l'astérö̈de B 612.

Aruyari tẽ muruxawamirĩ uri yepé tetama suí sera waá “iwaka-retama B 612".

(Creio mesmo que o principezinho veio de uma região cujo nome é "região do céu B 612”.)

ou neste, C.15/L.11, quando o principezinho chega ao planeta habitado pelo geógrafo:

"Elle est bien belle, votre planète. Est-ce qu'il y a des océans?"

- Ne retama puranga retana. Aikwé será paranãwasú-itá iké?

(- A sua ${ }^{99}$ região é muito bonita. Há oceanos ${ }^{100}$ aqui?)

\footnotetext{
${ }^{98} \mathrm{Nem}$ todos os substantivos que se iniciam pela letra $t$ - são substantivos pluriformes.
} 
Dessa forma, reservei iwaka-retama ou sua forma reduzida tetama (retama, setama) às traduções de planète e astéroüde, traduzindo étoile por yasitatá, palavra utilizada desde o tupi antigo para a tradução de "estrela". Somente traduzi a referência a asteroides ou a planetas por yasitatá quando ela foi estabelecida de forma deliberada no livro, como na já citada linha 37 do capítulo 26, quando o pequeno príncipe chama seu asteroide/planeta de estrela.

\section{- Pepusantá (avião)}

A respeito do objeto que o pequeno príncipe desconhecia e que é o instrumento de trabalho do aviador - o avião -, traduzi-o por pepusantá (asa dura), estabelecendo a mesma associação entre palavras que se observa na criação lexical pepo'atã (asa dura), em guarani paraguaio. No C.3./L.5-6 o narrador-aviador explica ao principezinho a função desse objeto:

“Qu'est-ce que c'est que cette chose-lá?

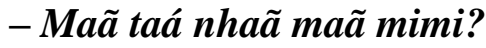

(- O que é aquela coisa ali?)

- Ce n'est pas une chose. Ça vole. C'est un avion. C'est mon avion."

- Nhaã ti yepé maã. Nhã̃ uwewé. Nhã̃ yepé pepusantá. Se pepusantá.

(- Aquilo não é uma coisa. Aquilo voa. Aquilo é um avião. Meu avião.)

Essa explicação aparece após o leitor já ter tomado conhecimento do C.1./L.1819, em que o aviador diz:

J'ai donc dî choisir un autre métier et j'ai appris à piloter des avions.

Aramé arikuté aparawaka amú murakí asuí ayumbué atiari pepusantá.

\footnotetext{
99 Ainda que a tradução literal de ne retama seja "tua região", utilizei o pronome possessivo "sua", devido ao uso do pronome de tratamento "você" como pronome pessoal de segunda pessoa em português.

100 Como já aludido na nota 75, paranãwasú traduz literalmente "riozão" ou "rio grande", por extensão utiliza-se na tradução de "mar" e "oceano".
} 
(Então tive de escolher outro trabalho e aprendi a pilotar aviões.)

J'ai volé un peu partout dans le monde.

\section{Awewé ana xinga Iwí pawa ara rupí.}

(Já voei um pouco sobre toda a Terra.)

A partir desses excertos o leitor toma conhecimento de que pepusantá é algo que se pilota, que é algo conduzido por alguém e que com ele é possível viajar a muitos lugares. Dessa forma, o neologismo utilizado na tradução de "avião" encontra respaldo interpretativo nas referidas passagens do livro.

\section{- Yurú-pukwarisara (mordaça)}

No C.7/L.45 o neologismo yurú-pukwarisara (aquilo que amarra a boca, amarrador de boca) serviu à tradução de muselière (mordaça, focinheira). Nesse excerto, o narrador oferece ao pequeno príncipe o desenho de uma mordaça para que ele protegesse a bela flor que habitava seu asteroide do cordeiro, a fim de que este não a comesse. Nessa composição, a palavra yurú, cujo significado é "boca", aparece em relação genitiva com pukwarisara (pukwari: “amarrar", “atar”, "ligar” + -sara: “-(d)or”, "aquilo que"). Antes de chegar a essa tradução, também cogitei a possibilidade de utilizar a composição tĩ-pukwarisara (aquilo que amarra o focinho, amarrador de focinho), estabelecida pelo substantivo tĩ (nariz; bico, focinho) e por pukwarisara (amarrador). Ainda que "focinho" pudesse ser interpretado pela parte frontal da cabeça dos animais, formada por ventas, boca e queixo, preferi o uso de yurú a tĩ para que ficasse explícito que a principal função da mordaça era amarrar a boca do animal para que ele não comesse a planta.

\section{- Iwitepuka (vulcão)}

Assim como a palavra suumé, já analisada anteriormente, uma criação lexical de Ermanno Stradelli (1929/2014, p.308), a palavra iwitepuka figura em seu dicionário, 
apesar de não a encontrarmos em outros registros da literatura em nheengatu. Esse termo, cunhado pelo conde italiano, é desconhecido pelos atuais falantes de nheengatu. Assim, optei por resgatar esse neologismo composto pelos termos iwitera (serra) e puka (rebentadado, estourado; fendido, aberto).

No asteroide do pequeno príncipe havia três vulcões, dois em atividade e um extinto, os quais eram revolvidos diariamente para que não entrassem em erupção. Assim, traduzi no C.9/L.2 volcans en activité (vulcões em atividade) por iwitepuka-itá upuka rẽ waá (vulcões que ainda rebentam/estouram) e no C.9/L.4 volcan éteint (vulcão extinto) por iwitepuka uwéu uikú waá (vulcão que está apagado). Assim, por meio dessas descrições, especifiquei a característica de cada um dos vulcões.

\section{- Iwitú-pitasukasara (para-vento)}

No C.8/L.23, o principezinho, ao atender ao pedido de sua rosa para que a protegesse do frio e das correntes de ar, arruma-lhe um para-vento. Dessa forma iwitúpitasukasara (aquilo que sustenta/segura o vento, segurador do vento) foi empregado na tradução de paravent (para-vento).

\section{- Yasí-mukameẽsára (calendário)}

Entre os vários lugares que o pequeno príncipe conheceu antes de chegar à Terra, um deles é um asteroide habitado por um rei, um monarca absoluto que acreditava reinar sobre tudo, inclusive sobre todos os planetas e estrelas, os quais obedeciam às suas ordens. Maravilhado com tamanho poder, o pequeno príncipe lhe pede que ordene um pôr do sol para que pudesse se lembrar de seu asteroide. No entanto, como esse rei somente dava ordens razoáveis, disse ao pequeno viajante que esperaria o momento em que as condições fossem favoráveis. Assim, o monarca consulta um enorme calendário para se orientar sobre o horário aproximado em que o sol iria se pôr. Nesse contexto, a palavra calendrier (C.10/L.46) foi traduzida por yasímukameẽsára (aquilo que mostra os meses, mostrador dos meses). Mukameẽ significa "mostrar", "indicar", "apresentar", e yasí, cujo significado original é "lua", também traduz "mês". A criação lexical yasí-mukameẽsára foi influenciada pelo registro de ara- 
mukameẽsára (aquilo que mostra o tempo, mostrador do tempo) na tradução Taína-itá akangaisima retama (2016) de A terra dos meninos pelados, de Graciliano Ramos, realizada por Marcel Twardwsky Ávila. Atualmente a palavra "relógio" não possui correspondência semântica em nheengatu, contudo sabe-se que o registro aramukameẽsára já foi utilizado por falantes de gerações passadas, permanecendo ainda hoje na memória de alguns deles, principalmente os mais velhos e mais experientes no idioma (ÁVILA, 2016, p. 106). Desse modo, em Taína-itá akangaisima retama essa palavra foi resgatada para a tradução de "relógio", instrumento que mostra as horas, o tempo ${ }^{101}$. Como o calendário é um instrumento que indica os meses, traduzi calendrier por yasí-mukameẽsára, formando, assim, uma composição nova na língua com base em um registro em desuso na mesma.

\section{- Mira-siyesara e muruxawa-siyesara (trem e carruagem)}

Ainda com base na tradução de Ávila (2016), o uso de outros dois neologismos foi guiado por sua leitura. Em Taína-itá akangaisima retama a composição mirasiyesara (aquilo que transporta gente, transportador de gente) serviu à tradução de "automóvel”. Tal palavra constrói-se pela relação genitiva entre o verbo siyé (transportar, conduzir, carregar) acoplado ao sufixo -sara e o substantivo mira (gente, pessoa). Mira-siyesara, como aludido por Ávila, é uma descrição genérica que pode servir à tradução de qualquer meio de transporte utilizado na locomoção de pessoas (2016, p. 106). Assim, fiz uso dessa composição na tradução de train (C.22/L.4) e de rapide (C.22/L.5), palavras que, respectivamente, podem ser traduzidas por "trem" $\mathrm{e}$ “expresso" e referem-se a um tipo de transporte coletivo.

Ademais, tal construção auxiliou-me na tradução de "carruagem" (C. 10/L. 53), a qual se fez por muruxawa-siyesara (aquilo que transporta o rei, transportador de rei) na passagem em que o rei diz ao pequeno príncipe:

(...) Je suis très vieux, je n'ai pas de place pour un carrosse, et ça me fatigue de marcher.

\footnotetext{
${ }^{101}$ A palavra ara, traduzida por "tempo", também traduz "dia" e "mundo". A acepção de ara irá variar de acordo com o contexto em que ela se encontra, na rede de significações estabelecida com outras palavras a ela relacionadas.
} 
(...) Tuyué retana aikú, iké ti mayé arikú yepé muruxawa-siyesara, asuí se kweré apitá mairamé arikuté awatá.

((...) Estou muito velho, aqui não há como eu ter uma carruagem, e fico cansado quando tenho de andar.)

Assim, carrosse (carruagem, coche) foi traduzido por muruxawa-siyesara, devido à condução referir-se em um contexto específico àquilo que seria utilizado para o transporte do rei.

\section{- Miasua muruxawawara (general, ministro e embaixador)}

No C.10, o principezinho, assim que chega ao planeta do rei, logo é identificado por este como um súdito, o pequeno viajante ainda não sabia que para os reis todas as pessoas são seus súditos. Dessa forma, na L.4, traduzi sujet (súdito) por miasua, uma palavra antiga do nheengatu, que caiu em desuso, cujo significado original é "escravo", "servo" e, por extensão, “empregado". Devido a isso, utilizei miasua em seu sentido expandido para me referir à ideia de "subordinado", ou seja, todos aqueles que estão abaixo do rei, que excercem suas atividades sob as ordens de seu superior.

Ao longo da conversa com o principezinho, o rei menciona o nome de três cargos que poderiam ser ocupados em seu reino: géneral (general), ministre (ministro) e ambassadeur (embaixador). Todos esses nomes foram traduzidos pelo neologismo miasua muruxawawara (súdito real, funcionário real). Ainda que essa composição seja formada pelo resgate de duas palavras em desuso em nheengatu - miasua e muruxawa, a associação entre ambas é nova na língua. A palavra muruxawa, com a qual é formado o termo muruxawawara, como mencionado na seção que trato da escolha do título da tradução, é uma palavra não mais utilizada hoje em dia que se traduz por "chefe", mas que, como se viu, foi empregada para nomear cargos de lideranças políticas. Devido ao caráter genérico dessa palavra, neste trabalho a empreguei na tradução de "príncipe" e "rei", respectivamente muruxawamirĩ (principezinho) e muruxawa (rei). Quando associada ao sufixo -wara (o que é de), que permite a formação de adjetivos, obtêm-se muruxawa-wara, "o que é do rei" ou "real". Assim, 
justaposto ao substantivo miasua, forma-se a nova associação lexical miasua muruxawawara (súdito real, funcionário real).

Como os termos "general", "ministro" e "embaixador" não são reiterados ao longo do livro, julguei satisfatória a tradução desses três nomes pelo neologismo com emprego genérico miasua muruxawawara. Contudo, no caso de "ministro", foi preciso especificar essa função, visto que o rei, após propor ao principezinho que se tornasse seu ministro, é indagado por este sobre a função de ministro que desempenharia. Assim, no C.10/L.49-51, lê-se:

- Ne pars pas, répondit le roi qui était si fier d'avoir un sujet. Ne pars pas, je te fais ministre!

- Té resú - unheẽ muruxawa, surí uikú waá nhã̃sé urikú yepé miasua. - Té resú rẽ, amuyeréu indé se miasua muruxawawara arã!

(- Não vá - disse o rei, que estava feliz porque tinha um súdito. - Não vá ainda, eu transformo você em meu súdito real!)

- Ministre de quoi?

- Maã miasua nungara taá?

(- Que espécie de súdito?)

- De... de la Justice!

- Satambikasawa supé arã!

(- Para a Correção!)

Nesses excertos, houve a necessidade de especificar um dos cargos, o de ministro da justiça. Como não há uma palavra em nheengatu que traduza o conceito de justice (justiça), apropriei-me do adjetivo satambika (correto) acrescido do sufixo substantivador -sawa, formando, assim, o substantivo satambikasawa (correção). 
- Muyereusara e mira-siyesara tiarisara (manobreiro e maquinista)

A respeito dos passageiros que se agitam nas plataformas para embarcar nos trens, ou expressos, o principezinho conversa com o manobreiro, a pessoa responsável por despachar os trens para um lado ou para o outro. No texto original, em francês, a palavra que se refere a essa profissão é aiguilleur (C.22/L.2). A tradução mais direta dessa palavra ao português, embora com acepção pouco conhecida, seria "agulheiro", que segundo o dicionário digital Caldas Aulete é o "funcionário que movimenta agulha nas linhas férreas", sendo essa agulha a "ponta móvel de um trilho que, ao ser pivotada, engata em outro trilho, permitindo a mudança de via de trem ou bonde" (AULETE, 2017). A tradução de tal termo não gerou convergência nas traduções de Le Petit Prince à língua portuguesa ${ }^{102}$, como pode ser visto nesta tabela:

\begin{tabular}{|l|l|}
\hline SAINT-EXUPÉRY/BARBOSA (1975) & “guarda-chaves" (p. 74) \\
\hline SAINT-EXUPÉRY/BARBOSA (2008) & “manobreiro" (p. 72) \\
\hline SAINT-EXUPÉRY/GULLAR (2013) & “manobreiro" (p. 148) \\
\hline SAINT-EXUPÉRY/BETTO (2015) & “despachante” (p. 102) \\
\hline SAINT-EXUPÉRY/LIMEIRA (2015) & “guarda-chaves” (p. 136) \\
\hline
\end{tabular}

\section{Tabela 3: Aiguilleur nas traduções de Le Petit Prince ao português}

Em Muruxawamirĩ optei pelo termo muyereusara (aquele que faz virar, virador), composto pelo verbo yeréu (virar) associado ao prefixo causativo $\mathrm{mu}^{103}$ e ao sufixo agentivo -sara, aproximando-o assim de "manobreiro", a pessoa que realiza manobras nas linhas férreas. No entanto, na primeira ocorrência da palavra aiguilleur (C.22/L.2), escolhi traduzi-la por mira-siyesara muyereusara (aquele que faz virar aquilo que transporta pessoas, virador do transportador de pessoas), uma construção extensa, mas explicativa pelo fato de, nesse momento do livro, ainda não estar claro em que consiste

\footnotetext{
102 Somente foram consideradas traduções ao português brasileiro.

103 O prefixo mu- é o morfema utilizado no emprego da voz causativa, ou seja, "aquela em que alguém causa uma ação ou um processo, mas não os realiza" (NAVARRO, 2016, p. 55). Assim, "eu faço meu cachorro correr" traduz-se ao nheengatu por ixé amuyana se yawara (eu faço correr meu cachorro), em que muyana se decompõe em mu- (fazer) + yana (correr). A anteposição do afixo mu- ao verbo intransitivo yana torna-o um verbo transitivo (fazer correr $\mathrm{X}$ ). Além disso, esse prefixo pode ser utilizado com outras classes de palavras, transformando-as em verbo, por exemplo: sakú (quente), musakú (esquentar); kwara (buraco, furo), mukwara (esburacar, furar).
} 
o trabalho do manobreiro. Somente após a indagação do principezinho é que se entende a funcão desse trabalho (C.22/L.4):

(...) J'expédie les trains qui les emportent, tantôt vers la droite, tantôt vers la gauche.

(...) Amusemu mira-siyesara-itá urasú waá aintá, amuramé katusawa kití, amuramé yaparasawa kití...

((...) Faço sair os transportadores de pessoas que as levam, às vezes para a direita, às vezes para a esquerda...)

Dessa forma, define-se o trabalho do manobreiro, ocupação que, a partir desse momento, passa a ser traduzida apenas por muyereusara (o virador) ${ }^{104}$. A necessidade de uma tradução cuidadosa do termo aiguilleur justifica-se no confronto entre essa ocupação, orientar a saída dos trens, e o trabalho desempenhado pelo maquinista, a pessoa que conduz o trem, referido no livro como l'homme de la locomotive (o homem da locomotiva). Tal construção foi traduzida ao nheengatu (C.22/L.7) por mira-siyesara tiarisara (aquele que dirige/pilota aquilo que transporta pessoas, piloto do transportador de pessoas). Segundo Ávila, o verbo tiari, que se traduz, entre outras possibilidades, por “dirigir" e "pilotar" e que é utilizado pelos falantes atuais do nheengatu, não foi encontrado na literatura antiga sobre a língua (2016, p. 128).

\section{- Piripanasawa ruka (loja)}

No C.21/L.40, a raposa diz ao pequeno príncipe que as pessoas só conhecem bem aquilo que cativaram e que hoje em dia os homens já não conhecem bem mais nada porque compram tudo pronto em lojas. Consequentemente, pelo fato de não existir lojas que vendem amigos, os homens já não têm mais seus amigos. Nesse contexto, traduzi chez le marchand e point de marchand, que se traduzem por "comércio" ou "loja", por piripanasawa ruka (casa de compra), composição formada pelo verbo piripana (comprar) acrescido do sufixo nominalizador -sawa em uma relação genitiva com o

\footnotetext{
104 Após a primeira ocorrência, mais explicativa que as demais, há ainda mais sete menções à personagem, cuja designação sempre foi traduzida por muyereusara.
} 
substantivo pluriforme $u k a$ ( $r u k a$, suka), cuja tradução é "casa". Tal neologismo foi cunhado por Eduardo de Almeida Navarro em seu Curso de Língua Geral (2016).

\section{- Ii-kwara wawakawara e iwitú wawakawara (polia e cata-vento)}

Depois de andar muito pelo deserto em busca de um lugar onde pudessem saciar a sede, o principezinho e o aviador encontram um poço já equipado com roldana, corda e balde. Assim, no C.25/L.5 traduzi a palavra poulie (polia, roldana) por ií-kwara wawakawara (roda do buraco d'água, roda do poço), composição formada pela relação genitiva da palavra wawakawara (de wawaka (rodar) mais o sufixo -wara, que indica o hábito, a constância ou a frequência com que algo é feito) com ií-kwara (literalmente, "buraco d'água"). O entendimento desse neologismo é facilitado pela ilustração contida do capítulo 25, na qual o poço, com a polia e a corda, é representado.

Ademais, nesse mesmo capítulo, a palavra girouette (cata-vento) foi utilizada em uma comparação com polie (polia) (C.25/L.7):

Et la poulie gémit comme gémit une vieille girouette quand le vent a longtemps dormi.

Nhã̃ ií-kwara wawakawara ukururuka mayé yepé iwitú wawakawara aíwa yawé, mairamé uikupukú ana iwitú-íma.

(Aquela roda do buraco d'água (polia) gemia como uma roda de vento (catavento) velha, quando já demora sem vento.)

A palavra girouette, cuja tradução é "cata-vento", pode ser o aparelho que indica a direção e a velocidade do vento ou o mecanismo utilizado para retirar água do poço, acionado pela força do vento. Como no contexto analisado a referência está associada ao poço a que o principezinho e o aviador tinham chegado, preferi traduzir girouette por iwitú wawakawara (roda de vento), em consonância com a tradução de polie, visto que o cata-vento de um poço é uma roda que gira com a força imprimida pelo vento. 


\title{
5.2.3. Circunlóquios
}

Nesta seção apresento alguns casos em que utilizei descrições em nheengatu para traduzir palavras em francês que estão inseridas em um contexto específico e cujo sentido geral foi recuperado no texto traduzido. Por meio de circunlóquios, ou perífrases, tentei traduzir o sentido de uma palavra ou expressão recriando no texto traduzido o contexto adequado à sua recepção. Essa modalidade de tradução aproximase da definição de modulação apresentada por Aubert:

\begin{abstract}
Ocorre modulação sempre que um determinado segmento textual for traduzido de modo a impor um deslocamento perceptível na estrutura semântica de superfície, embora retenha o mesmo efeito geral de sentido no contexto e co-texto específicos. Ou, para retomar Saussurre, os significados são parcial ou totalmente distintos, mas mantêm-se, em termos genéricos, o mesmo sentido. (AUBERT, 1998, p. 108)
\end{abstract}

Assim, no início do C.1, após a ilustração do primeiro desenho que o narrador fez em sua infância, desenho este inspirado em um livro sobre a Floresta Virgem que ele leu aos seis anos de idade (C.1/L.5), lê-se:

J'ai alors beaucoup réfléchi sur les aventures de la jungle et, à mon tour, j'ai réussi, avec un crayon de couleur, à tracer mon premier dessin.

Aramé amanduari retana kaá mbeusawa-itá resé asuí, se rupí tẽ, amunhãkwáu, yepé pinimasara rupiara irumu, se yepesawa kwatiarisawa.

(Então pensei muito sobre as histórias da mata e, por mim mesmo, pude fazer, com um instrumento de pintor, meu primeiro desenho.)

Nesse exemplo a palavra crayon de couleur (lápis de cor) foi traduzida por pinimasara rupiara (instrumento de pintor). No entanto, como primeira solução, utilizei a palavra pinima-íwa, encontrada no dicionário de Ermanno Stradelli (1929/2014, p. 456), composta pelo adjetivo pinima (pintado) e pelo substantivo íwa (planta, haste), composição que o conde italiano empregou na tradução de "pincel" (1929/2014, p. 456). O registro pinima-íwa, contudo, não foi bem aceito entre falantes de nheengatu em uma pesquisa lexical que fiz em São Gabriel da Cachoeira. Diante do desconhecimento e estranhamento em relação ao registro de Stradelli, a professora Celina Menezes da Cruz, em comunicação pessoal, sugeriu-me a utilização de 
pinimasara rupiara, construção formada por pinima (pintar) ${ }^{105}$ acrescido do sufixo sara (-(d)or), formando, assim, pinimasara (pintor), palavra em relação genitiva com rupiara (o que é próprio para, instrumento). Assumindo pinimasara rupiara como uma descrição genérica relacionada a qualquer tipo de pintura e desenho, também utilizei esses termos na tradução de stylographe (caneta, caneta-tinteiro) no C.2/L.28. A partir dessa escolha, foi possível traduzir outil (ferramenta) no C.7/L.42 por murakí rupiara (instrumento de trabalho), descrição genérica relacionada às palavras petekasara (martelo) e beruma (parafuso) no C.7/L.43.

Tais ferramentas foram utilizadas pelo narrador-aviador para o conserto do seu avião após um pouso forçado no deserto do Saara. Para a tradução de "deserto" fiz uso da descrição tetama mira-íma, composta por tetama (terra, região; pátria) e mira (pessoa, gente) junto do sufixo -íma (sem). Como o deserto referido no livro é o deserto do Saara (C.2/L.1), cogitei a possibilidade de traduzir o nome dessa região por iwikuitiwawasú (grande ajuntamento de areia), ou mesmo por iwikuí-retama (terra de areia).

Contudo, optei pela forma tetama mira-íma, escolha que se sustenta no contexto do C.2/L.22:

Il n'avait en rien l'apparence d'un enfant perdu au milieu du désert, à mille milles de toute région habitée.

Aé ti tẽ yepé kurumimirĩ nungara uyusupari waá yepé tetama mira-íma upé, apekatú retana mayewa tetama suí-ntu mamé mira-itá umurari.

(Ele não era mesmo como um menininho que se perdeu em uma terra sem gente, muito distante de qualquer região onde pessoas moravam.)

Nessa passagem, estabelece-se de forma explícita a oposição entre deserto (ou terra sem gente) e regiões onde pessoas moram. Ademais desse excerto, a escolha de tetama mira-íma é corroborada em outras passagens do livro, como no C.17/L.13:

\footnotetext{
${ }^{105} \mathrm{Na}$ verdade, pinima se traduz pelo adjetivo "pintado", e a forma correspondente ao verbo "pintar" é mupinima. No entanto, a forma pinima vem sendo utilizada há muito tempo na formação do nome "pintor". Stradelli, por exemplo, registra pinimasara como "pintor" (1929/2014, p. 456), ainda que a forma gramatical correta seja mupinimasara (mupinima (pintar) + -sara (-(d)or)). Devido ao uso propagado de pinimasara como "pintor", optei por utilizar essa forma, mais comum aos falantes de nheengatu.
} 
- Ici c'est le désert. Il n'y a personne dans les déserts. La Terre est grande”, dit le serpent.

- Yaikú yepé tetama mira-íma upé. Ti yamaã nẽ awá tetama-itá mira-íma upé. Iwí turusú - unheẽ buya.

(- Estamos em uma terra sem gente. Não vemos ninguém nas terras sem gente. A Terra é grande - disse a cobra.)

Em seu dicionário, Ermanno Stradelli atribuiu a acepção "deserto" à entrada mira-íma (1929/2014, p. 413), registro que não figura em outros textos sobre o nheengatu, e, embora o conde italiano não identifique as palavras por classes morfológicas, o uso de mira-íma parece estar relacionado ao adjetivo "deserto". Miraíma se traduz literalmente por "sem gente", assim uma "casa deserta" seria uma $u k a$ mira-íma (casa sem gente), da mesma forma que uma tetama mira-íma (terra sem gente), uma descrição que explica uma característica dos desertos.

Deixando de lado a referência ao deserto, às ferramentas e aos lápis de cor e falando um pouco sobre o planeta do pequeno príncipe, o asteroide B 612, o narrador conta a seus leitores que um astrônomo turco o descobrira em 1909 e divulgara sua descoberta em um congresso internacional de astronomia, dessa forma, no C.4/L.7, traduzi:

Il avait fait alors une grande démonstration de sa découverte à un congrès internacional d'astronomie.

Nhã̃ akayú ramé, aé umukamẽ̃ $i$ wasemusawa yepé wayurí upé yasitatásikarisara-itá irumu Iwí retama riía suiwara.

(Naquele ano, ele mostrou sua descoberta em um encontro com astrônomos de várias regiões da Terra.)

Nessa passagem, empreguei o extenso circunlóquio "encontro com astrônomos de várias regiões da Terra" para caracterizar um congresso internacional de astronomia $^{106}$.

\footnotetext{
106 Nesse circunlóquio empreguei o já analisado neologismo yasitatá-sikarisara (pesquisador das estrelas), na tradução de astronome (astrônomo).
} 
Ainda sobre o asteroide B 612, sabe-se que nele o pequeno príncipe cuidava de uma bela rosa, a quem dedicava muita atenção, ainda que ela fosse extremamente vaidosa e muitas vezes o importunasse. Assim, além de protegê-la das correntes de ar com um para-vento, o principezinho também a colocava à noite sob uma redoma para protegê-la do frio. Assim, no C.8/L.25, traduzi globe (globo, redoma) por riruwasú sakakanga (grande recipiente transparente). Pensando em algo translúcido que servisse de proteção à frágil flor, traduzi inicialmente globe por riruwasú itá-werawa suiwara (grande recipiente de vidro), influenciado, muito possivelmente, pelo registro "itáueraua: cristal, vidro, pedra que resplandece, que reluz" anotado por Ermanno Stradelli $(1929 / 2014 \text {, p. 385 })^{107}$. Considerando a construção riruwasú itá-werawa suiwara muito extensa pelo fato de a palavra globe aparecer sete vezes no livro e analisando o sentido de "globo", que, segundo o dicionário digital Caldas Aulete, pode ser uma "esfera de vidro, porcelana, plástico ou outro material transparente ou translúcido, destinada a arrefecer o brilho da fonte luminosa e tornar difuso o fluxo luminoso" (AULETE, 2017), decidi utilizar o substantivo rirú (vasilha, paneiro; recipiente), acresido do sufixo de grau aumentativo -wasú (-ão; grande), especificado pelo adjetivo sakakanga (transparente). Dessa forma a composição ficou mais compacta, sem perder a característica de descrição do objeto.

Além desse, outro circunlóquio foi utilizado no C.1/L.23, após o narrador mencionar que os adultos, durante sua infância, desencorajaram-no de seguir uma promissora carreira de pintor, tendo se tornando, quando adulto, um aviador. Sobre o contato com outros adultos, diz:

J'ai ainsi eu, au cours de ma vie, des tas de contacts avec des tas de gens sérieux.

Yawé, se rikwesawa pukusawa, akwáu ana siía mira musarái-íma-wera waáitá.

(Assim, durante minha vida, já conheci várias pessoas que eram desacostumadas a brincar.)

\footnotetext{
107 Itá-werawa se traduz literalmente por "pedra que brilha".
} 
Percebe-se, nesse excerto, a tradução de gens sérieux (gente séria, pessoas sérias) por mira musarái-íma-wera waá-itá (pessoas que eram desacostumadas a brincar). Não seria adequado, para o contexto, a tradução de gens sérieux por "pessoas que não riem", visto que as pessoas sérias são identificadas como adultas, aquelas que julgam suas preocupações de trabalho como mais importantes do que as brincadeiras de criança. Como as brincadeiras relacionam-se ao universo infantil, em contraposição ao trabalho, relacionado aos adultos, a expressão "pessoas que eram desacostumadas a brincar" se equivale a "gente séria".

Uma pessoa assim é descrita pelo pequeno príncipe quando ele viaja a um asteroide habitado por um homem de negócios, um sujeito muito trabalhador que nunca tinha tempo para fazer outra coisa senão contas. Inserido nesse contexto, no C.13/L.1 businessman (empresário) foi traduzido por apigawa umunhãwera-ntu waá paparisawa-itá (homem que só era acostumado a fazer contas), uma descrição que já antecipa o tipo de ocupação desempenhado por esse homem. Em algumas ocorrências de businessman (há nove delas no livro), empreguei apenas a forma nhã̃ apigawa (aquele homem) ou apigawa (o homem), sempre que a referência a essa personagem já tinha sido estabelecida. Pelo fato de passar todos os dias sentado, contando as estrelas do céu e anotando o número delas em um papel, para depois guardá-lo no banco, o empresário se gabava de ser um homem rico e trabalhador e dizia que apenas três vezes em sua vida havia sido interrompido. Destarte no C.13/L.12 lê-se:

La seconde fois ç'a été, il y a onze ans, par une crise de rhumatisme. Je manque d'exercise. Je n'ai pas le temps de flâner. Je suis sérieux, moi.

Mukũisáwa, aikwé ana mukũipú-yepé akayú, mairamé asaã aikú siía sasisawa se pira resé. Ti akataka, ti mayé awatá mirupí. Ixé yepé apigawa murakisara.

(A segunda (vez), já faz onze anos, quando estava sentindo muitas dores em meu corpo. Não me mexo, não (há) como eu andar por aí. Eu (sou) um homem trabalhador. ${ }^{108}$ )

Nesse trecho crise de rhumatisme (crise de reumatismo) foi traduzido por sila sasisawa se pira resé (muitas dores em meu corpo), um circunlóquio que explica o que

\footnotetext{
${ }^{108}$ As palavras entre parênteses foram adicionadas por mim para deixar a leitura em português mais fluente.
} 
se sente em uma crise de reumatismo. Além disso, a reiteração da palavra sérieux (sério), agora em contraposição a flâner (perambular, zanzar), levou-me a traduzi-la por apigawa murakisara (homem trabalhador). No entendimento do empresário, uma pessoa séria não tem tempo para pensar em bobagens, assim, sem dar ouvidos àquilo que o principezinho lhe dizia, ele reforça (C.13/L.6):

(...) Je suis sérieux, moi, je ne m'amuse pas à des balivernes!

(...) Ixé yepé apigawa murakisara, ti amanduari tenhuntusawa resé!

((...) Eu sou um homem trabalhador, não penso em bobagens!)

Desse modo, quando o principezinho conta ao narrador que conhecera o empresário e que este vivia a repetir que era um homem sério, traduzi no C.7/L.30:

"Je suis un homme sérieux! Je suis un homme sérieux!"

“Ti amanduari tenhuntusawa resé, ixé yepé apigawa murakisara! Ixé yepé apigawa murakisara!”

("Não penso em bobagens, eu sou um homem trabalhador! Eu sou um homem trabalhador!")

Nesse trecho, nota-se o acrésimo de "não penso em bobagens" à fala do empresário para deixar claro a sua crítica àquilo que ele não julga como sério, a tudo aquilo que não se relaciona ao trabalho.

Além da visita ao asteroide habitado pelo empresário, o principezinho faz várias viagens a outros asteroides, para que tivesse uma ocupação e pudesse se informar a respeito deles. Em uma de suas viagens chegou a um asteroide habitado por um homem vaidoso, uma pessoa que gostava de ser admirada por todos. Assim, no C.11/L.2, lê-se:

“Ah! Ah! Voilá la visite d'un admirateur!” s'écria de loin le vaniteux dès qu'il aperçut le petit prince.

- Ah! Ah! Xukúi yepé mira usaisú umaã waá se resé! - unheẽ apigawa warixí mairamé umaã muruxawamirĩ. 
(- Ah! Ah! Eis uma pessoa que ama olhar em mim! - disse o homem vaidoso quando viu o principezinho.)

Nesse excerto, a palavra admirateur (admirador) foi traduzida pela descrição mira usaisú umaã waá se resé (pessoa que ama olhar em mim), visto que não há em nheengatu uma única palavra que corresponda a "admirador".

Como os vaidosos apenas gostam de escutar elogios, eles fingem não escutar qualquer tipo de comentário que não os enalteça. Com base nisso no C.11/L.14 fiz uso de mais um circunlóquio:

Mais le vaniteux ne l'entendit pas. Les vaniteux n'entendent jamais que les louanges.

Ma apigawa warixí ti usendú aé. Apigawa-itá warixí usendú-ntu mira-itá mairamé tá unhẽ̃ maã-itá puranga aintá resewara.

(Mas o homem vaidoso não o escutou. Os homens vaidosos só escutam as pessoas quando elas dizem coisas boas a respeito deles.)

Nessa passagem, o termo louange (elogio) foi desdobrado em maã-itá puranga aintá resewara (coisas boas a respeito deles), uma descrição que procura recuperar o sentido de louange no contexto em que está inserido. Preocupado em continuar sendo admirado pelo principezinho, o vaidoso lhe pergunta (C.11/L.15):

"Est-ce que tu m'admires vraiment beaucoup?" demanda-t-il au petit prince.

- Supí será resaisú remã̃-mã̃ se resé? - upurandú aé muruxawamirĩ supé.

(- É verdade que você ama ficar olhando em mim? - perguntou ele ao principezinho.)

Em consonância com o circulóquio utilizado na tradução de admirateur (admirador), o verbo admirer (admirar), empregado na $2^{\mathrm{a}}$ pessoa do singular, foi traduzido pela locução verbal resaisú remaã-mã̃ (amas ficar olhando) ${ }^{109}$.

109 Somente traduzi "você ama ficar olhando" no excerto citado acima (C.11/L.15) porque estou empregando em todas as traduções do nheengatu ao português o pronome "você" em vez de "tu". 
Além desse asteroide, o pequeno viajante também visitou um planeta habitado por um geógrafo. Nele, o geógrafo, estudioso que escrevia em livros enormes, nunca abandonava o seu escritório para ver as cidades, os rios, as montanhas, os mares, os oceanos e os desertos, visto que tal trabalho, segundo ele, cabia aos exploradores. Para que os exploradores não mentissem aos geógrafos, o que causaria uma catástrofe nos livros de geografia, estes eram acostumados a fazer um interrogatório sobre a descoberta dos exploradores e sobre a moralidade desses viajantes. Desse modo, no C.15/L.18, tive de empregar várias palavras para tentar uma aproximação com sentido geral da palavra moralité (moralidade):

Et si les souvenirs de l'un d'entre eux lui paraissent intéressants, le géographe fait faire une enquête sur la moralité de l'explorateur.

Mairamé yepé iwí-kwausara usendú manungara amurupí, aé upurandú siía maã watawera suí, umã̃ arã sa nhã̃ aé umbeú waá ti será yepé puité.

(Quando um geógrafo escuta algo diferente, ele pergunta várias coisas para o viajante $^{110}$, para ver se aquilo que ele conta não é uma mentira.)

Nesse contexto, o entendimento de "moralidade" ou "moral” é possível pelo circunlóquio no qual se diz que uma análise daquilo que o explorador conta ao geógrafo é feita, ou seja, se ele não diz a verdade, sua moral é posta em xeque.

Após deixar o planeta do geógrafo, o principezinho se dirige à Terra. Chegando àquele enorme planeta, ele se depara com uma serpente, com quem conversa sobre os homens. Tal serpente é indagada pelo principezinho por não falar, em certos momentos, de modo claro, explícito, expressando-se por meio de mensagens cifradas, por meio de enigmas. No C.17/L.32, lê-se:

- Oh! J'ai très bien compris, fit le petit prince, mais pourquoi parles-tu toujours par énigmes?

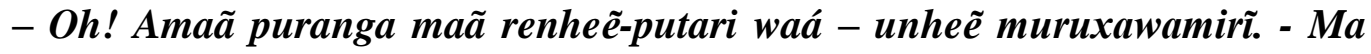
marã taá renheẽ nheenga-itá rupí uyumimi waá-itá maã renheẽ-putari waá?

\footnotetext{
${ }^{110}$ Watawera (viajante) foi a palavra utilizada para a tradução de explorateur (explorador).
} 
(- Oh! Vejo bem o que você quer dizer - disse o principezinho. - Mas por que você diz por meio de palavras que escondem o que quer dizer?)

No circunlóquio que proponho, "enigma" é traduzido por "palavras que escondem o que alguém quer dizer".

Ainda na Terra, o principezinho encontra uma raposa, que se torna sua amiga e lhe ensina muitas coisas, entre as quais a importância da amizade, que se efetua quando se cativa alguém e criam-se laços entre aqueles que se gostam. Dessa forma, no C.21/L.8, apprivoiser (cativar) foi inicialmente traduzido por yaputí piá kwara upé (amarrar dentro do coração). Contudo, essa escolha teria de acompanhar o seguinte raciocínio: se o principezinho cativa a raposa, é a raposa quem o amarra dentro de seu coração (o coração da raposa); se a raposa cativa o principezinho, é ele quem a amarra dentro de seu coração (o coração do principezinho). Como esse raciocínio poderia gerar algum tipo de confusão, minha segunda tentativa foi traduzir apprivoiser por pisika piá (pegar o coração, tocar o coração), dessa forma eliminaria a inversão semântica exposta acima, pois, se alguém pegou o coração de uma pessoa, ele cativou essa pessoa. No entanto, como no C.21/L.16 a raposa explica ao pequeno príncipe que "cativar" é o mesmo que "criar laços", finalmente traduzi apprivoiser por yusá piá (laçar o coração) ${ }^{111}$. Assim, no C.21/L.8, lê-se:

- Je ne puis pas jouer avec toi, dit le renard. Je ne suis pas apprivoisé.

- Ti amusarai-kwáu ne irumu - unhẽ̃ yawara kaapura. - Indé ti rẽ reyusá se piá.

(- Não posso brincar com você - disse a raposa ${ }^{112}$. - Você ainda não laçou meu coração.)

Logo após ouvir isso, o principezinho, curioso para saber o significado da palavra "cativar", insiste com a raposa para que ela lhe explique o que quis dizer com tal palavra. Assim, repete três vezes a pergunta Qu'est-ce que signifie "apprivoiser"?

\footnotetext{
${ }^{111}$ Agradeço a valiosa ajuda de Celina Menezes da Cruz e de Marcel Twardowsky Ávila na escolha desses termos.

112 "Raposa", na verdade, não é a tradução de yawara kaapura. Falerei sobre isso na próxima seção, em que trato de algumas questões culturais.
} 
(O que significa “cativar”?), que, por vir após o C.21/L.8, citado acima, traduzi por Maã taá renheẽ-putari kwá nheenga-itá irumu? (O que você quer dizer com estas palavras?) (C.21/L.11) ${ }^{113}$, dessa forma evitei a repetição dos termos que traduzem apprivoiser até culminar na explicação contida no C.21/L.16:

- C'est une chose trop oubliée, dit le renard. Ça signifie "créer des liens...".

- Nhã̃ nheenga-itá umukamẽ̃ manungara siía mira tá resarái ana waá -

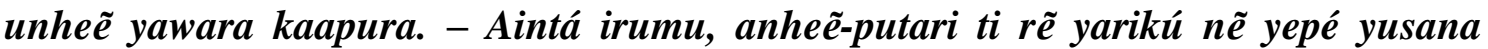
nungara umuapiri waá yandé.

(- Aquelas palavras indicam algo que muitas pessoas já se esqueceram - disse a raposa. - Com elas, quero dizer que ainda não temos nenhuma espécie de laço que nos una.)

Nesse grande circunlóquio tentei explicar que laçar o coração de alguém é o mesmo que ter uma espécie de laço que sirva à união das pessoas que se gostam, do mesmo modo que apprivoiser (cativar) se relaciona a créer des liens (criar laços).

Para que alguém cative outra pessoa é preciso que haja uma aproximação lenta entre as pessoas que estão se conhecendo, é preciso que haja um ritual que permita, por exemplo, que um espere ansiosamente pela chegada do outro. Desse modo, inserido nesse contexto, no C.21/L.44, vê-se:

"Il eût mieux valu revenir à la même heure, dit le renard. Si tu viens, par exemple, à quatre heures de l'après-midi, dès trois heures je commencerai d'être heureux.'

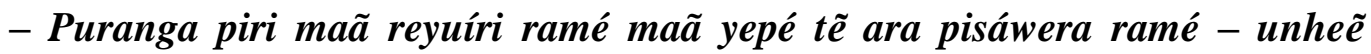
yawara kaapura. Reyuri ramé muíri ara karuka pitérupi, karuka yupirungawa ramé ana se rurí.

(- Seria melhor se você viesse em uma mesma parte do dia - disse a raposa. Se você vem todos os dias no meio da tarde, já no começo da tarde eu serei feliz.)

\footnotetext{
${ }^{113}$ Também utilizei a forma Maã taá renheẽ-putari nhaã nheenga-itá irumu? (O que você quis dizer com aquelas palavras?) (C.21/L.13 e L.15).
} 
Traduzi, nesse excerto, la même heure (a mesma hora) por yepé tẽ ara pisáwera (uma mesma parte do dia), visto que o nheengatu carece de uma palavra que traduza heure (hora). A partir dessa estratégia, traduzi também quatre heures (quatro horas) por karuka pitérupi (meio da tarde) e trois heures (três horas) por karuka yupirungawa (começo da tarde) somente a fim de estabelecer a diferença entre as partes do dia e permitir a interpretação de que a ansiedade irá aumentando à medida que se aproxima o horário em que os amigos sempre se encontram.

Nesse mesmo capítulo, C.21, outras duas sentenças importantes de Le Petit Prince foram traduzidas por meio de circunlóquios. Na L.63, no momento em que o principezinho está triste por ter de se despedir da sua amiga raposa para seguir sua viagem, ela amorosamente lhe diz:

- Adieu, dit le renard. Voici mon secret. Il est très simple: on ne voit bien qu'avec le cœur. L'essentiel est invisible pour les yeux.

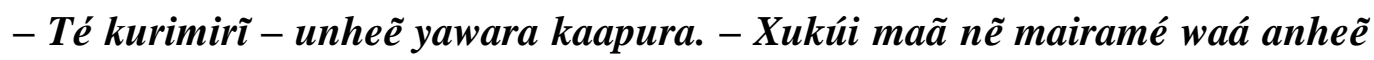
nẽ awá supé: yamaã-ntu puranga yané piá irumu. Yané resá ti umaã-kwáu maã-itá rumitera.

(- Até logo - disse a raposa. - Eis o que nunca disse a ninguém: só vemos bem com o nosso coração. Nossos olhos não podem ver o interior das coisas.)

Nessa passagem, "segredo" foi traduzido por "o que nunca disse a ninguém" porque, além de o nheengatu não possuir uma palavra que traduza esse conceito, o segredo a que a raposa se refere é uma mensagem que ela transmite ao principezinho. A mensagem dita, que só se vê bem com o coração, auxilia o entendimento de l'essentiel est invisible pour les yeux (o esssencial é invisível aos olhos), traduzido por yané resá ti umaã-kwáu maã-itá rumitera (nossos olhos não podem ver o interior das coisas) ${ }^{114}$. Nesse contexto, "o interior das coisas", apesar de traduzir "essencial" aparentemente de um modo mais material, físico, pensando "essência" em relação a "cerne" ou àquilo que está no meio de algo, também permite a interpretação como "âmago" ou àquilo que é íntimo a alguém. "Essencial", no contexto do livro, poderia ser traduzido por "o que é mais importante", e aquilo que é mais importante não se vê, é o interior de tudo, onde

\footnotetext{
${ }^{114}$ Agradeço, mais uma vez, a ajuda de Marcel Twardowsky Ávila na tradução desse excerto.
} 
estão guardados os sentimentos mais nobres. Assim, dentro do contexto geral do livro, a referência ao interior das coisas atinge um nível de abstração que extrapola qualquer tipo de referenciação voltada à matéria física.

Ademais desse circunlóquio, nesse mesmo capítulo, no momento em que a raposa diz ao pequeno príncipe que ele era responsável por tudo aquilo que tinha cativado e que, portanto, era responsável pela flor que habitava em seu asteroide, traduzi, na L.67, tu deviens responsable pour toujours de ce que tu as apprivoisé (você se torna eternamente responsável por aquilo que cativou) por rerikuté repisirũ awá piá reyusá waá (você precisa proteger o coração de quem você laçou). Com essa tentantiva, busquei aproximar o verbo pisirũ (defender, proteger, cuidar) de responsable (responsável), no sentido de ter de ser responsável por algo, ter de cuidar de algo. Essa responsabilidade está relacionada à pessoa, ou metonimicamente ao coração da pessoa, que teve o seu coração laçado por alguém que a tornou cativa.

\title{
5.2.4. Questões culturais
}

Nesta seção serão apresentadas as situações em que a distância cultural entre as línguas envolvidas na tradução de Le Petit Prince, do francês ao nheengatu, mostrou-se significativa a ponto de eu optar por escolhas tradutológicas que promovessem a acomodação de algumas referências culturais ao ambiente a que a tradução se destina.

Segundo Aubert, a adaptação:

\begin{abstract}
denota uma assimilação cultural; ou seja, a solução tradutória adotada para o segmento textual dado estabelece uma equivalência parcial de sentido, tida por suficiente para os fins do ato tradutório em questão, mediante uma intersecção de traços pertinentes de sentido, mas abandona qualquer ilusão de equivalência "perfeita". (AUBERT, 1998, p. 108)
\end{abstract}

Esses traços a que Aubert se refere permitem a identificação entre o termo da língua fonte e o termo traduzido, que possuem traços semânticos que os aproximam, mas são distintos culturalmente.

Com base nisso, no C.1/L.29, quando o narrador, ao relatar seu convívio frustrado com outros adultos, diz je lui parlais de bridge, de golf, de politique et de cravates (eu lhe falava de bridge, de golfe, de política e de gravatas), optei, em minha tradução, por adequar o conteúdo dessa mensagem à realidade amazônica. 
Se bridge e golfe são jogos que apetecem os adultos que partilham da cultura de origem, teria de se pensar, no ambiente amazônico, em atividades lúdicas que interessam aos adultos e que não são do gosto das crianças. Isso seria difícil, pois atividades recreativas muito praticadas como futebol e voleibol, por exemplo, são do gosto tanto dos adultos como das crianças. Assim, como o excerto destacado concerne a assuntos de interesse que extrapolam as atividades de lazer, escolhi traduzi-lo por apurungitá tetama-itá ruixawa-itá resé asuí muamundewa-itá resé (Eu falava sobre os chefes das nações e sobre roupas). Como não foi possível segregar o interesse dos adultos ao das crianças em relação a atividades de lazer, optei por omitir tal informação.

A composição tetama-itá ruixawa (chefes das nações) ${ }^{115}$, que serviu à tradução de politique (política), apresenta a restrição semântica da palavra tuixawa ${ }^{116}$ (chefe) em relação à palavra tetama (nação), mas, com isso, não se estabelece uma restrição ao ambiente das comunidades ribeirinhas do Rio Negro, visto que estas seriam mais bem delimitadas pela palavra tendawa (lugar, sítio; comunidade). Assim, por meio dessa referência difusa, traduzida por tetama, escolhi a aludida tradução com o propósito de ser possível relacioná-la à administração das lideranças de diferentes terras, regiões, pátrias. Já a tradução de cravates (gravatas), uma veste acessória utilizada em geral por homens adultos inseridos em ambientes formais, metonimicamente, foi efetuada por munhamundewa-itá (roupas). Pelo fato de as mulheres se incumbirem de afazeres como lavar roupas à beira do rio, e essa prática não ser, normalmente, desempenhada por crianças, a escolha da tradução sugerida foi motivada pela adaptação à cultura de destino.

Ainda em relação àquilo que caracteriza a visão de mundo dos adultos, que é muito diferente do modo como as crianças percebem as coisas, o narrador, crítico em relação às preocupações da vida adulta e saudoso de sua infância, diz no C.4/L.25:

J'aurais aimé commencer cette histoire à la façon de contes de fées. J'aurais aimé dire: "Il était une fois un petit prince qui habitait une planète à peine plus grande que lui, et qui avait besoin d'un ami..."

\footnotetext{
${ }^{115}$ Tetama, de forma mais apropriada, significa "pátria, lugar do nascimento" (STRADELLI, 1929/2014, p. 498)

${ }^{116}$ Tuixawa é uma palavra pluriforme, de modo que assume a forma ruixawa quando está relacionada a outro substantivo.
} 
(Adoraria começar esta história como os contos de fadas. Adoraria dizer: "Era uma vez um principezinho que morava em um planeta um pouco maior do que ele e que tinha necessidade de um amigo...”)

Nesse excerto, a referência a contes de fées (contos de fadas) e a fórmula que dá início a eles il était une fois (era uma vez) marcam um tipo de narrativa que circula sobretudo entre o público infantil. Assim como os contos de fadas, há na cultural oral amazônica muitas lendas, mitos e contos que são transmitidos de geração a geração. João Barbosa Rodrigues, por exemplo, coletou muitos deles em seu livro Poranduba Amazonense (1890), que também é chamado por ele de Kochiyma-uara Porandub. Como já foi visto em seção anterior que trata dessa obra, poranduba, segundo seu autor, significa "historias phantasticas, fabulas, abusões" (RODRIGUES, 1890, p. II). Kuxiimawara, conforme a grafia adotada neste trabalho, compõe-se do advérbio kuxiíma (antigamente) acrescido do sufixo -wara (o que é de), essa junção possibilita a formação do adjetivo kuxiimawara, que se traduz, literalmente, por "o que é de antigamente" ou, melhor, por "antigo".

A maioria desses enredos apresenta como fórmula de abertura uma partícula que caracteriza a oralidade da transmissão, trata-se da forma paá, que pode ser traduzida por “contam", “contam que”, “dizem” e "dizem que”. Segundo Stradelli, sobre o uso de paá, "quem relata o fato, não o afirma, mas o põe à conta dos que o contaram antes dele" (1929/2014, p. 446). Como exemplo disso, assim se dá o início da lenda Curupira Caamunuçara Irumo (O Curupira e o Caçador), registrada por Barbosa Rodrigues: Yepé apegaua, paá, ис̧u исатипи. Ucaíma caâpe (...) (Um homem, contam, foi caçar. Perdeu-se no mato (...)) (1890, p.35).

Com base nesses elementos culturais traduzi o excerto de Le Petit Prince citado acima por (C.4/L.25):

Aputari mã̃ ayupirũ kwá papera mayé marandua-itá kuxiimawara yawé. Aputari mã̃ ayupirũ aé kwayé: “Aikwé, paá, yepé muruxawamirĩ umurari waá yepé iwaka-retama upé turusú piri xinga i suí, awá supé uwatari rẽ yepé sumuara...” 
(Gostaria de começar este livro como as histórias antigas. Gostaria de começá-lo assim: "Contam que havia um principezinho que morava em um planeta um pouco maior do que ele, para quem ainda faltava um amigo...”)

Nessa tradução empreguei paá (contam que) na tradução il était une fois (era uma vez) e, para a tradução de contes de fées (contos de fadas), preferi utilizar a construção marandua-itá kuxiimawara (histórias antigas), em que o termo marandua, registrado na literatura antiga sobre o nheengatu como "conto", "história" e "narrativa", foi empregado no lugar de poranduba por seu uso ser mais frequente em textos de diferentes autores. Hoje em dia, segundo Ávila, embora as acepções mais usuais empregadas a marandua sejam "notícia", "novidade", "boato" e "mexerico", os falantes mais velhos do idioma atestam o uso da palavra conforme as suas acepções mais antigas (2016, p.82). Corrobora ainda o uso de marandua com a acepção de "história" o fato de esse termo vir associado à palavra kuxiimawara (antigo), o que desabona a interpretação "novidade antiga"; assim, o uso de marandua foi empregado na tradução que proponho conforme seu antigo significado ${ }^{117}$.

Após essa consideração a respeito das narrativas em nheengatu, na tradução de Le Petit Prince, em algumas situações, decidi adaptar a referência a alguns animais ou plantas à realidade amazônica. Por exemplo, no C.8/L.19, traduzi tigre (tigre) por yawareté-pinima (onça pintada). Nesse caso, poderia também ter optado por utilizar a palavra "tigre" como empréstimo da língua portuguesa, que provavelmente seria entendida pelos falantes de nheengatu. Contudo, devido a ambos os animais serem grandes felinos, optei pela adaptação de tigre, animal característico da Ásia, a onçapintada, animal encontrado em toda a América Latina.

No C.21, por sua vez, o principezinho encontra uma raposa, uma importante personagem do livro, com quem mantém uma longa conversa. O nome "raposa" traduziu, em muitas narrativas em nheengatu, a palavra mikura, cujo significado, na verdade, é "gambá". Ermanno Stradelli em seu extenso vocabulário abona: "raposa: mycura (que é quem representa o papel desta, nos contos indígenas)" (1929/2014, p. 281). Além de Stradelli, Dom Frederico Costa considera raposa como "micura" (1909,

117 A palavra marandua foi também empregada com a acepção de "história" na construção do neologismo mirasawa-itá marandua (história das gerações), que serviu à tradução da disciplina escolar "história". 
p. 241). Couto de Magalhães em muitas lendas de $O$ Selvagem (1876/1975) traduz mikura tanto por "raposa" como por "gambá". João Barbosa Rodrigues explica em uma das lendas que transcreveu: "Micura ou Mucura, é o Didelphis Azarac, marsupio pedimano conhecido no Rio de Janeiro por Gambá e em outras Provincias por Sariguê, Sarué, no Estado Oriental por Micuré e pelos Incas do Peru por Intuto" (1890, p. 173).

Diferentemente do gambá, a raposa, pelas características físicas que apresenta, pode ser pensada como um animal aparentado com o cão ${ }^{118}$, da mesma forma que o lobo, que, assim como a raposa e o cão, também faz parte da família dos canídeos. Stradelli traduziu em seu dicionário a palavra "lobo" por iauarasu, que literalmente se traduz por "cachorro grande, cachorrão" (1929/2014, p. 245). Na seção nheengatuportuguês, o conde italiano traduziu iauarasu por "lobo, Canis jubatus" (1929/2014, p. 376). A designação espécie-tipo canis jubatus corresponde ao lobo-guará, animal endêmico da América do Sul ${ }^{119}$. Stradelli também registra no verbete "cão-do mato" a explicação “(Canis azarae) Iauaperi, Iauara-asu” (1929/2014, p. 183). A classificação canis azarae corresponde em francês ao nome do animal renard d'aszara, também conhecido pelo nome renard de la pampa, cuja tradução ao português é "raposa dos pampas" ${ }^{120}$. Assim se percebe, por meio dessas considerações, a sobreposição de designações que iauarasu (ou yawarawasu, com base na grafia adotada neste trabalho) acumula, servindo explicitamente à tradução de "lobo" e de "cão-do-mato", como, de modo menos evidente, à tradução de lobo-guará e de uma espécie de raposa.

Ainda que autores antigos tenham traduzido "raposa" por mikura (gambá), em Muruxawamirĩ, considerando as semelhanças entre raposas, lobos e cães, traduzi a palavra renard (C.21/L.1) - canídeo conhecido como "raposa" - pelos termos yawara

\footnotetext{
118 Raposa: "denominação comum a diversos mamíferos da família dos canídeos, especialmente os do gênero Vulpes, de pelo castanho-avermelhado, pernas relativamente curtas, focinho longo, orelhas pontudas e cauda longa, aparentado com o cão" (AULETE, 2017).

119 Informação obtida inicialmente na página: https://pt.wikipedia.org/wiki/Lobo-guar\%C3\%A1. Acesso em 14/01/2017. O embasamento teórico ao conteúdo da pesquisa verifica-se em: http://www.science.smith.edu/msi/pdf/i0076-3519-234-01-0001.pdf. Acesso em 14/01/2017.

120 Informação obtida inicialmente na página: https://fr.wikipedia.org/wiki/Renard_d'Aszara. Acesso em 14/01/2017. O embasamento teórico ao conteúdo da pesquisa verifica-se em: http://archive.wikiwix.com/cache/?url=http\%3A\%2F\%2Fwww.bulletin-officiel.developpementdurable.gouv.fr\%2Ffiches\%2Fexboenvireco\%2F200101\%2FA0010008.htm. Acesso em 14/01/2017.
} 
kaapura (cachorro-do-mato) ${ }^{121}$. Trata-se de uma designação genérica em nheengatu, podendo se referir a diferentes tipos de cães não domesticados.

No C.21/L.4, a raposa, que estava debaixo de uma macieira, avista pela primeira vez o pequeno príncipe. Devido à inexistência de uma palavra que traduza pomme (maçã) e, consequentemente, pommier (macieira), substituí a referência a pommier por kumãíwa (cumaí) ${ }^{122}$, uma árvore típica do Amazonas que produz um fruto que, segundo Stradelli, é "do tamanho de uma bela nêspera, de gosto delicado quando madura" (1929/2014, p. 353).

Da mesma forma, alterei a referência a "trigo" e a "pão" por nomes de alimentos que podem ser traduzidos ao nheengatu. Assim, no C.21/L.34, traduzi:

- Et puis regarde! Tu vois, là-bas, les champs de blé? Je ne mange pas de pain. Le blé pour moi est inutile. Les champs de blé ne me rappellent rien.

- Asuí, remaã! Indé remaã-kwáu apekatú kwá suí awatí kupixawa-itá? Ti ambaú miapé. Ixé arã awati ti puranga. Awatí kupixawa-itá, ti tá umumanduari ixé nẽ mã̃ resé.

(- Depois, veja! Você consegue ver longe daqui os campos de milho? Não como miapé. Para mim o milho não é bom. Os campos de milho não me fazem lembrar de nada.)

Com essa adaptação, traduzi a palavra blé (trigo) por awatí (milho), visto que em nheengatu não há uma palavra que traduza "trigo". A escolha de awatí foi motivada pela comparação que a raposa estabelece entre a cor do cabelo do pequeno príncipe e o trigo, ambos dourados. Desse modo, no C.21/L.36, traduzi blé (trigo) por awatí rawa (barba do milho) pelo fato de ambos se assemelharem à cor do cabelo do principezinho. Nesse contexto, diz a raposa:

- Le blé, qui est doré, me fera souvenir de toi. Et j'aimerai le bruit du vent dans le blé...

\footnotetext{
${ }^{121}$ Agradeço enormemente à professora Celina Menezes da Cruz pela sugestão dos termos yawara kaapura.

${ }^{122}$ Agradeço novamente à professora Celina Menezes da Cruz por mais esta sugestão.
} 
- Awati rawa, tawá waá, umumanduari kurí ixé ne resé. Asaisú kurí tiapú awatí rawa umunhã waá mairamé iwitú upeyú...

(- A barba do milho, que é amarela, me fará lembrar de você. Amarei o barulho que a barba do milho faz quando o vento sopra...)

Além dessa adaptação ao ambiente linguístico e cultural do nheengatu, na já citada linha 34 do capítulo 21, traduzi a palavra pain (pão) por miapé, uma espécie de bolo, salgado ou doce, que pode ser feito de várias massas, como mandioca, milho e trigo $^{123}$. A associação entre "pão" e miapé, contudo, já se estabelece, pelo menos, desde o término do século XIX, visto que Couto de Magalhães traduziu em seu curso de nheengatu "pão" por miapé e "padeiro" por miapé munhangara, que literalmente significa “fazedor de pão" (1975, p. 14).

Ainda no capítulo 21, houve mais uma adaptação ao contexto amazônico, no momento em que a raposa diz ao pequeno príncipe que para ela o dia mais feliz é aquele em que os caçadores deixam o trabalho e vão dançar com as moças do vilarejo, porque, nesse dia, ela pode andar tranquilamente pela vinha, sem correr nenhum tipo de perigo. Dessa forma, no C.21/L.46, adaptei vigne (vinha) a kukuratiwa (ajuntamento de cucuras). Diferentemente das uvas, que brotam em videiras, a cucura nasce em árvore, mas com alguns tipos de uva assemelha-se na cor e no tamanho e, também, por seus frutos formarem-se em cachos; assim, é conhecida por muitos como a "uva do Amazonas"124.

Outra adaptação ao ambiente amazônico se deu no C.25/L.27, quando traduzi chou (repolho) por karurú (caruru), no contexto em que o principezinho diz ao aviador que os baobás que ele havia desenhado mais se pareciam com repolhos do que com baobás. Ainda que não se saiba ao certo a origem da palavra "caruru", ela encontra-se integrada ao léxico tupi há muito tempo, visto que desde o século XVII nota-se a sua presença em textos que tratam do tupi antigo. Eduardo Navarro em seu Dicionário de Tupi Antigo (2013), ao abonar a palavra kararu, correspondente à grafia "caruru", menciona como fonte de pesquisa a obra Historia Naturalis Brasiliae, composta por George Marcgrave e publicada pela primeira vez em 1648 (2013, pp. 222 e 619).

\footnotetext{
${ }^{123}$ Tais informações foram obtidas em comunicação pessoal com a professora Celina Menezes da Cruz. ${ }^{124}$ Informações obtidas em comunicação pessoal com a professora Celina Menezes da Cruz.
} 
Por fim, no C.23/L.3, quando o principezinho se depara com um vendedor de pílulas especiais que saciavam a sede, traduzi pilule (pílula) por pusanga (puçanga), palavra utilizada desde o tupi antigo, grafada posanga, com o sentido de "remédio, puçanga, mezinha; antídoto; poção, beberagem, feitiço; remédio preparado pelos pajés; purgante, unguento" (NAVARRO, 2013, p. 402). Dessa forma, assumindo pusanga em seu sentido mais genérico, como uma espécie de medicamento, sentido este também empregado nos dias atuais, utilizei esse termo na tradução de pilule. 


\section{Considerações finais}

Ainda que propostas de tradução ao nheengatu mostrem-se um enorme desafio àqueles que pretendem contribuir para o fortalecimento dessa língua, sobretudo àqueles que, como eu, estudaram tardiamente esse idioma e por isso terão de enfrentar dificuldades relacionadas à sensibilidade expressiva do texto que estão produzindo, essa tarefa, que exige do tradutor o conhecimento não apenas dos recursos linguísticos de que a língua dispõe, mas também do repertório cultural a ela relacionado, permite que conheçamos de perto a história viva que essa língua preserva e entendamos mais a respeito da riqueza cultural que seus falantes carregam de geração a geração.

Estratégias como a revitalização linguística por meio de traduções podem, ao expor os falantes de nheengatu a um número maior de textos nessa língua, permitir que a escolha de uma variante ortográfica e a produção autoral escrita possam vir a se firmar, contribuindo aos poucos para o início de uma tradição nessa modalidade discursiva.

O registro escrito do nheengatu é uma maneira de valorizar o uso dessa língua e de permitir que seus falantes e interessados em geral possam estudá-la e divulgá-la em diferentes suportes (rádio, televisão, internet), com a pretensão de que futuramente ocupe outros espaços no ambiente amazônico e seja vista com mais prestígio na sociedade em que se insere. 


\section{Bibliografia}

AGUIAR, José Lourenço da Costa. (1898) Christu muhençáua çurimaan-uára arama nhihingatu rupi - doutrina christã destinada aos naturais do Amazonas em nhihingatu. Petrópolis: Pap. e Tip. PACHECO, SILVA \& C. Disponível em: http://www.brasiliana.usp.br/bitstream/handle/1918/00166400/001664_COMPLETO.pd f. Acesso em 11/01/2017.

ALTMAN, Cristina. (2012) As partes da oração na tradição gramatical do tupinambá/nheengatu. Limite, São Paulo, n⿳ํㅡ, 6, pp. 11-51.

AMORIM, Antônio Brandão de. (1987) Lendas em Nheengatu e em Português. Edição fac-similar à primeira edição, de 1926. Manaus: Fundo Editorial - ACA.

ANCHIETA, José de. (2014) Arte de gramática da lingoa mais vfada na cofta do Brasil (1595). Apresentação de Fernando da Rocha Peres. $5^{a}$ ed. Salvador: EDUFBA.

ANDRADE, Mário de. (2012) Macunaíma, o herói sem nenhum caráter. Estabelecimento do texto: Telê Ancona Lopes \& Tatiana Longo Figueiredo. Rio de Janeiro: Nova Fronteira.

ANDRADE, Oswald de. (1972) Do Pau-Brasil à Antropofagia e às Utopias. Introdução de Benedito Nunes. Rio de Janeiro: Editora Civilização Brasileira.

ARROJO, Rosemary. (1986) Oficina de tradução: a teoria na prática. São Paulo: Ática.

ASSIS, Machado de. Americanas. Fundação Biblioteca Nacional, disponível em: http://www.dominiopublico.gov.br/pesquisa/DetalheObraForm.do?select_action=\&co_ obra=2062. Acesso em 10/01/2017.

AUBERT, Francis Henrik. (1993) As (in)fidelidades da tradução: servidões $e$ autonomia do tradutor. Campinas, UNICAMP.

(1998) "Modalidades de tradução: teoria e resultados". In: TradTerm, São Paulo, v. 5.1, p. 99-128.

AULETE, Caldas. Caldas Aulete Digital. Fonte: http://www.aulete.com.br/. Acesso em $11 / 01 / 2017$.

ÁVILA, Marcel Twardowsky. (2016) Estudo e prática da tradução da obra infantil A terra dos meninos pelados, de Graciliano Ramos, do português para o nheengatu. Dissertação de Mestrado defendida na Universidade de São Paulo, 199 f.

ÁVILA, Marcel Twardowsky Ávila \& TREVISAN, Rodrigo Godinho. (2015) "Jaguanhenhém: um estudo sobre a linguagem do Iauaretê". In: Revista Magma, São Paulo, $\mathrm{n}^{\mathrm{0}} \quad 12, \mathrm{pp}$. 297-335. Disponível em: http://www.revistas.usp.br/magma/article/view/98404. Acesso em 11/01/2017. 
AZENHA, João. (2006) "Linguística textual e tradução: redefinindo o conceito de marca cultural”. In.: TradTerm, 12, São Paulo, p.13-32.

(2010) "Transferência cultural em tradução: contextualização, desdobramentos, desafios". In.: TradTerm, 16, São Paulo, p.37-66.

BASSNETT, Susan. (2003) Estudos de Tradução: fundamentos de uma disciplina. Lisboa: Gulbenkian (Original edition London: Methuen).

BERMAN, Antoine. (2007) "Tradução Etnocêntrica e Tradução Hipertextual”. In.: A tradução e a letra, ou, $O$ albergue do longínquo. Tradução de Marie-Hélène Catherine Torres, Mauri Furlan e Andréia Guerini. Rio de Janeiro: 7Letras/PGET.

BOPP, Raul. (2013) Poesia completa de Raul Bopp. Organização de Augusto Massi. $2^{\text {a }}$ edição. Rio de Janeiro: José Olympio.

BRITTO, Paulo Henriques. (1999) “Tradução e Criação". In.: Cadernos de Tradução. Departamento de Língua e Literatura Estrangeiras (DLLE) - UFSC, Florianópolis, v.1, no -4 .

BROTHERSTON, Gordon \& SÁ, Lúcia. (2014). "Peixes, constelações e jurupari: a pequena enciclopédia amazônica de Stradelli”. In.: Vocabulário Português-Nheengatu, Nheengatu-Português. Cotia, SP: Ateliê Editorial.

CAMPOS, Haroldo de. (1992) "Da tradução como criação e como crítica". In: Metalinguagem \& outras metas. São Paulo: Perspectiva, pp. 57-63.

CANESE, Natalia Krivoshein de \& ALCARAZ, Feliciano Acosta. (1997) Néêrryru. Asunción: Instituto Superior de Lenguas, Universidad Nacional de Asunción.

CERVANTES, Miguel de. (1605) El ingenioso hidalgo don Quijote de la Mancha. Madrid: Juan de la Cuesta.

(2013) Kuimba'e katupyry ño Quijote yvyũngua. Tradução de Félix de Guarania. Servilibro: Asunción-Paraguay.

CHARRON, Marc. (2001) Berman, étranger à lui-même? Disponível em: https://www.erudit.org/revue/ttr/2001/v14/n2/000571ar.html. Acesso em 10/01/2017.

COSTA, Frederico. (1909) "Elementos necessários para aprender o nheengatú". In: Carta pastoral de D. Frederico Costa, bispo do Amazonas a seus amados diocesanos. Ceará: Typ. Minerva, pp. 157-248.

CRUZ, Aline da. (2011) Fonologia e Gramática do Nheengatú: a língua geral falada pelos povos Baré, Warekena e Baniwa. Tese (doutorado). Utrecht, Países Baixos: LOT. 652 páginas.

EDELWEISS, Frederico G. (1969) Estudos tupis e tupi-guaranis - confrontos e revisões. Rio de Janeiro: Livraria Brasiliana Editora. 
ESTEVES, Lenita Maria Rimoli. (2014) Atos de Tradução: éticas, intervenções, mediações. São Paulo: Humanitas: FAPESP.

ESTEVES, Lenita Rimoli \& AUBERT, Francis Henrik. (2008) "Shakespeare in the bush - história e tradução". In.: Tradução \& Comunicação - Revista Brasileira de Tradutores, no 17.

FREIRE, José Ribamar Bessa. (2011) Rio Babel: a história das línguas na Amazônia. 2. ed. Rio de Janeiro: EdUERJ.

(2009) "Tradução e interculturalidade: o passarinho, a gaiola e o cesto". In: ALEA, volume 11, nํㅡ 2, julho-dezembro, pp. 321-338.

(2000) 'Da 'fala boa' ao português na Amazônia brasileira". In: Diálogos

interdisciplinares: Amazônia em cadernos. Manaus: Museu Amazônico da Universidade Federal do Amazonas.

HOLANDA, Sérgio Buarque de. (1995) “A língua-geral em São Paulo”. In.: Raízes do Brasil. 26. ed. São Paulo: Companhia das Letras, pp. 122-133.

JIMENEZ, Juan Ramon. (1914) Platero y yo. Edición menor. Madrid, Ediciones de la lectura. (1986) Platero ha che. Tradução de Lino Trinidad Sanabria. Asunción.

LEITE, Fabiana Raquel. (2013) A Língua Geral Paulista e o "Vocabulário Elementar da Língua Geral Brasílica". Dissertação de mestrado defendida na Universidade Estadual de Campinas.

LOBO, Tânia C. Freire et al. (2006) "Indícios de língua geral no sul da Bahia na segunda metade do século XVIII". In: LOBO, Tânia et al. (Org.). Para a história do português brasileiro. vi: novos dados, novas análises. Salvador: EDUFBA, pp. 609630.

LOUREIRO, Antônio José Souto Loureiro. (1987) “Alerta ao leitor”. In: Lendas em Nheengatu e em Português. Manaus: Fundo Editorial - ACA.

LUTHER, Martin. (2006) “Carta aberta sobre a tradução" (1530). Tradução de Mauri Furlan. In: Furlan, M. (Org.). Clássicos da teoria da tradução. Edição bilíngue. Florianópolis: UFSC/NUPLITT, p. 91-115, v.4 (Renascimento).

MAGALHÃES, José Vieira Couto de. (1975) O Selvagem. São Paulo / Belo Horizonte, EDUSP / Itatiaia, edição fac-similar da $1^{\text {a }}$ edição de $O$ Selvagem, de 1876.

MICHAELIS. Michaelis francês-português. Fonte: http://michaelis.uol.com.br/. Acesso em 12/01/2017.

NAVARRO, Eduardo de Almeida. (2016) Curso de língua geral (nheengatu ou tupi moderno) - A língua das origens da civilização amazônica. $2^{a}$ edição. São Paulo, copyright Eduardo de Almeida Navarro. 
(2013) Dicionário de tupi antigo: a língua indígena clássica do Brasil. São Paulo: Global.

(2005) Método moderno de tupi antigo: a língua do Brasil dos primeiros séculos. 3. ed. São Paulo: Global.

(2004) "O domínio da língua castelhana sobre o guarani paraguaio". In.:

Revista Philologus, Rio de Janeiro. Disponível em: http://www.filologia.org.br/revista/artigo/10(29)09.htm. Acesso em 6 de outubro de 2015.

(2012) “O último refúgio da língua geral no Brasil”. In.: Revista de Estudos Avançados $d a$ USP, v. 26, pp. 245-254. Disponível em: http://tupi.fflch.usp.br/sites/tupi.fflch.usp.br/files/O\%20\%C3\%BAltimo\%20ref\%C3\%B Agio\%20da\%20L\%C3\%ADngua\%20Geral\%20no\%20Brasil_0.pdf. Acesso em 20 de outubro de 2015.

RODRIGUES, Aryon Dall'Igna. (1994) Línguas brasileiras: para o conhecimento das línguas indígenas. São Paulo: Edições Loyola.

RODRIGUES, João Barbosa. (1890) Poranduba amazonense, ou kochiyma-uara porandub (1872-1887). Rio de Janeiro: Tipografia de G. Leuzinger \& Filhos. Disponível em: http://www.etnolinguistica.org/biblio:rodrigues-1890-poranduba. Acesso em 11/01/2017.

ROSA, João Guimarães. (2013) "Meu tio o Iauaretê". In: Estas estórias. 6a edição. Rio de Janeiro: Nova Fronteira.

SÁ, Lúcia. (2012) Literaturas da Floresta: textos amazônicos e cultura latinoamericana. Rio de Janeiro: EdUERJ.

SAINT-EXUPÉRY, Antoine de. (1943) Le Petit Prince. New York: Reynal \& Hitchcock.

Gallimard.

(1999) Le Petit Prince. France: Collection Folio, copyright Éditions

(2005) Mitãmi. Tradução de De Las Nieves Domínguez e Enrique Chamorro. Asunción - Paraguay. Collection Folio, copyright Éditions Gallimard.

(1975) O Pequeno Príncipe. Tradução de Dom Marcos Barbosa. $18^{a}$ edição. Rio de Janeiro: Agir.

(2008) O Pequeno Príncipe. Tradução de Dom Marcos Barbosa. Ed. rev. Rio de Janeiro: Pocket Ouro.

(2013) “O Pequeno Príncipe”. In.: A bela história do pequeno príncipe. Tradução de Ferreira Gullar. $1^{a}$ edição. Rio de Janeiro: Agir. 
$\overline{\text { Editoral. }}$

(2015) O Pequeno Príncipe. Tradução de Frei Betto. São Paulo: Geração

(2015) O Pequeno Príncipe em Cordel. Tradução de Josué Limeira e Ilustrações de Vladimir Barros. Recife: Editora Carpe Diem.

SCHLEIERMACHER, Friedrich E. D. (2007) Sobre os diferentes métodos de traduzir (1813). Tradução de Celso Braida. Princípios, Natal, v.14, no 21, jan/jun.

SEIXAS, Manoel Justiniano de. (1853) Vocabulario da lingua indigena geral para o uso do Seminario Episcopal do Pará. Pará: Typ. de Mattos e Comp ${ }^{a}$. Disponível em: http://dedalus.usp.br/F/9YTB6K7TACQ166BSQQE6L13JHSI62US1PKYBRPPTNQU 1M7NUF2-16517?func=service-media-

exec\&doc_library=USP01\&doc_number $=000267363$

\&media_index=00001\&func_code=WEB-BRIEF. Acesso em 02/08/2015.

STRADELLI, Ermanno. (2014) Vocabulário Português-Nheengatu, NheengatuPortuguês. Cotia, SP: Ateliê Editorial.

TASTEVIN, Constantino. (1923) Grammatica da Lingua Tupy. São Paulo: Officinas do Diario Official. [Separata do Tomo XIII da Revista do Museu Paulista]

TUFIC, Jorge. (1987) "Brandão de Amorim e a literatura nacional”. In: Lendas em Nheengatu e em Português. Manaus: Fundo Editorial - ACA.

VENUTI, Lawrence. (2002) Escândalos da Tradução: por uma ética da diferença. Tradução de Laureano Pelegrin, Lucinéia Marcelino Villela, Marileide Dias Esqueda e Valéria Biondo; revisão técnica de Stella Tagnin. Bauru, SP: EDUSC. 